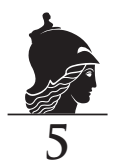




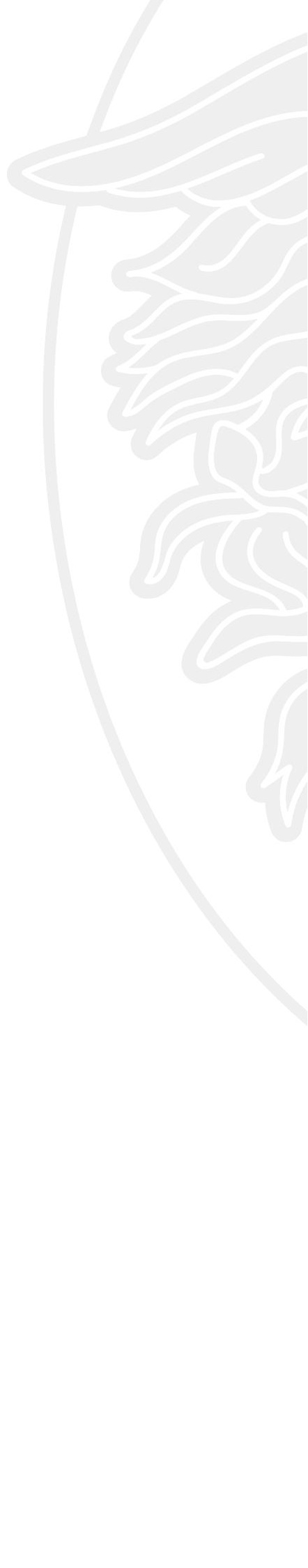




\section{BÉRES NÓRA}

\section{A BIZTONSÁGI TANÁCS ÁLTAL A NEMZETKÖZI BÜNTETŐBÍRÓSÁG ELÉ UTALT HELYZETEK LEGFONTOSABB JOGI PROBLÉMÁI}

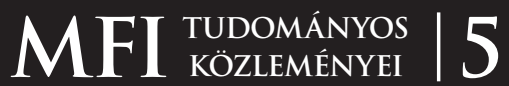




\section{A Biztonsági Tanács által a Nemzetközi Büntetőbíróság elé utalt helyzetek legfontosabb jogi problémái}

ISBN 978-615-6356-00-0 ISBN 978-615-6356-o1-7 (e-könyv)

DOI: 10.47079/2021.bn.btnbb.5

\section{Szakmai lektorok:}

Dr. Ádány Tamás Vince PhD

tanszékvezetô egyetemi docens, Pázmány Péter Katolikus Egyetem

Jog- és Államtudományi Kar, Nemzetközi Közjogi Tanszék

Prof. Dr. Kovács Péter DSc

egyetemi tanár, Pázmány Péter Katolikus Egyetem Jog- és Államtudományi Kar,

Nemzetközi Közjogi Tanszék

bíró, Nemzetközi Büntetőbíróság (2015-2024)

Prof. Dr. Sulyok Gábor

egyetemi tanár, Széchenyi István Egyetem, Állam- és Jogtudományi Kar,

Nemzetközi és Európai Jogi Tanszék

tudományos főmunkatárs, Társadalomtudományi Kutatóközpont, Jogtudományi Intézet

Mádl Ferenc Intézet Tudományos Közleményei

ISSN 2732-3242

Sorozatszerkesztő: Szilágyi János Ede

Kiadja a Mádl Ferenc Összehasonlító Jogi Intézet

Felelős kiadó: Szilágyi János Ede

Kézirat lezárásának időpontja: 2021. június 30.

Nyomdai előkészítés, tördelés és borítóterv:

Idea Plus (Kolozsvár)

Korrektúra: Szenkovics Enikő

Nyomdai kivitelezés: AK Nyomda Kft.

Felelős vezető: Káldor Gábor

Martonvásár, 2021 


\section{Tartalomjegyzék}

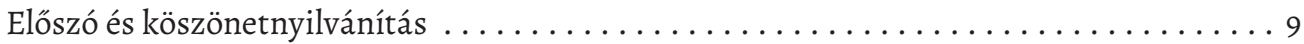

Lektori ajánlás Béres Nóra: A Biztonsági Tanácsáltal a Nemzetközi Büntetőbiróság

elé utalt helyzetek legfontosabb jogi problémái címú monográfiájához . . . . . . . . . . 11

Rövidítések jegyzéke................................... 14

I. RÉSZ: BEVEZETÉS. ................................... 19

1. A témaválasztás aktualitása, a könyv célja, tárgya,

szerkezeti felépítése és az alkalmazott kutatásmódszertan ............ 20

2. Alapvetés: a Biztonsági Tanács és a nemzetközi büntető igazságszolgáltatás . . . . 25

2.1. A Biztonsági Tanács megjelenése a nemzetközi büntető

igazságszolgáltatásban ......................... 25

2.2. A nemzetközi büntető igazságszolgáltatás normatív gyökerei

az Egyesült Nemzetek Alapokmányában . . . . . . . . . . . . . 29

2.3. A Biztonsági Tanács és a Nemzetközi Büntetőbíróság

kapcsolata a Nemzetközi Jogi Bizottság 1994. évi

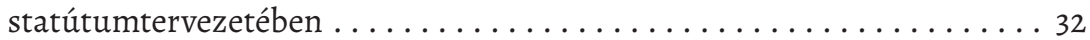

2.4. A Biztonsági Tanács és a Nemzetközi Büntetőbíróság

kapcsolatára vonatkozó elméletek..................... 34

2.4.1. A Biztonsági Tanácshoz fúződő funkcionalitás, avagy a Nemzetközi Büntetőbíróság mint

a nemzetközi béke és biztonság eszköze? . .............. 35

2.4.2. A Római Statútum központú funkcionalitás? .......... 37

2.4.3. Az intézményi autonómia ..................... 39

II. RÉSZ: A NEMZETKÖZI BÜNTETŐBÍRÓSÁG ÉS A BIZTONSÁGI TANÁCS

KAPCSOLATÁNAK NORMATÍV KERETEI A RÓMAI STATÚTUMBAN . . . . . . .41

3. A Nemzetközi Büntetőbíróság előtti eljárás megindítása

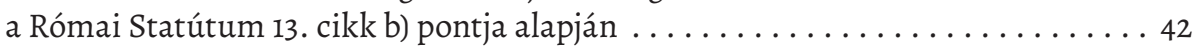

3.1. A Biztonsági Tanács mint eljárást indító mechanizmus $\ldots \ldots \ldots \ldots \ldots 42$

3.2. Dárfúr helyzete a Nemzetközi Büntetőbíróság előtt, avagy az 1593. (2005) BT-határozat megszületése ...............51

3.3. Líbia helyzete a Nemzetközi Büntetőbíróság előtt, avagy az 1970. (2001) BT-határozat megszületése .............. 56

3.4. A Biztonsági Tanács 1593. (2005) és 1970. (2011)

határozatainak értelmezése. ...................... 59

3.4.1. Az eljárások finanszírozásának kizárása .............60 60

3.4.2. A joghatóság kizárása ....................6 63

3.4.3. Az ENSZ-tagállamok együttmúködési kötelezettségének hiánya. . 66 
4. A Nemzetközi Büntetőbíróság előtti eljárás megindítása

a Római Statútum 15bis és 15 ter cikkei alapján . . . . . . . . . . . . . . . . 67

4.1. A Rómától Kampaláig vezető út . . . . . . . . . . . . . . . . . . . 67

4.2. Az agresszió bûntettével kapcsolatos anyagi jogi kérdések. ........ 68

4.3. Az agresszió bủncselekményével kapcsolatos eljárásjogi kérdések . . . . . 71

5. A Nemzetközi Büntetőbíróság előtti nyomozás vagy büntetőeljárás

felfüggesztése a Római Statútum 16. cikke alapján ............... 79

5.1. A nyomozás vagy büntetőeljárás felfüggesztésének feltételei . . . . . . . . 79

5.2. Az eljárás felfüggesztése a gyakorlatban $\ldots \ldots \ldots \ldots \ldots \ldots \ldots \ldots 81$

5.3. Az eljárás felfüggesztésére tett „kísérletek” ................ 85

III. RÉSZ: A NEMZETKÖZI BÜNTETŐBÍRÓSÁG ÉS A BIZTONSÁGI TANÁCS

KAPCSOLATÁNAK GYAKORLATI PROBLÉMÁI $\ldots \ldots \ldots \ldots \ldots \ldots . \ldots . \ldots 9$

6. A Nemzetközi Büntetőbíróság és harmadik államok ................. 90

6.1. A harmadik államok jogállásának lényeges nemzetközi jogi vetületei

a Római Statútum szempontjából ......................99 90

6.2. A harmadik államok jogállása a Római Statútumban............. 94

7. A komplementaritás és a Biztonsági Tanács által kezdeményezett eljárások . . . . 100

7.1. Problémafelvetés: leszámolás a büntetlenség kultúrájával

vs. az államok büntetőmonopóliumának igénye ............... 100

7.2. Az elfogadhatóság tényállási elemei a Római Statútumban . . . . . . . . 104

7.3. Az állami hatóságok hajlandóságának és képességének hiánya

a Föügyészi Hivatal szakértői véleményében $\ldots \ldots \ldots \ldots \ldots \ldots \ldots \ldots \ldots \ldots$

7.4. Az elfogadhatóság megtámadása a Római Statútum 19. cikke alapján. . . . . 115

7.4.1. Esetjogi kontrasztok: Líbia elfogadhatósági kifogásai. . . . . . . . 117

7.4.1.1. Szajf Kadhafi első ügyének elfogadhatósága

a tárgyalás-előkészítő tanács határozata tükrében ...118

7.4.1.2. Abdullah al-Senussi ügyének elfogadhatatlansága

a tárgyalás-előkészítő tanács határozata tükrében ...121

7.4.1.3. Szajf Kadhafi első ügyének elfogadhatósága

és Abdullah al-Senussi ügyének elfogadhatatlansága

a fellebbviteli tanács ítéletei tükrében ...........123

7.4.2. Szajf Kadhafi elfogadhatósági kifogása ................125

8. Az együttmúködés, a nemzetközi elfogatóparancsok végrehajtása

és a Biztonsági Tanács által kezdeményezett eljárások ................134

8.1. Problémafelvetés: az államföi immunitás és a büntetlenség elleni harc . . . .134

8.2. A probléma normatív háttere. ........................138

8.2.1. Az együttmúködési kötelezettség a Biztonsági Tanács 1593. (2005)

határozatában............................138

8.2.2. Az államfóii immunitás és az együttmûkködési kötelezettség

a Római Statútumban ..........................139

8.2.3. Az államfői immunitás a nemzetközi szokásjogban

és a nemzetközi bíróságok joggyakorlatában 
8.3. A tárgyalás-előkészítő tanácsok határozatai az al-Bashír-ügyben 150

8.3.1. A „vertikális hatály” vizsgálata: az együttmúködési kötelezettség és az immunitás összeütközése esetén alkalmazható megközelítési módok ...

8.3.2. A „vertikális hatály” vizsgálata a Malawi-határozat tükrében: az immunitás-kérdés megközelítése a nemzetközi szokásjog szemszögéből........................156

8.3.3. A „vertikális hatály” vizsgálata a Kongói Demokratikus Köztársaságot elmarasztaló határozat tükrében: a kérdés megközelítése a Biztonsági Tanács határozata szemszögéből .........................159

8.3.4. A „vertikális hatály" vizsgálata: a kérdés megközelítése a Római Statútum 27. cikk (2) bekezdése felól . . . . . . . . . . 160

8.3.5. A „horizontális hatály” vizsgálata: az együttmúködési kötelezettség az egyes részes államok oldalán ..........................162

8.3.6. A politikai dimenzió vizsgálata: az Afrikai Unió ............. . . 165 8.4. A fellebbviteli tanács ítélete az al-Bashír-ügyben..................173

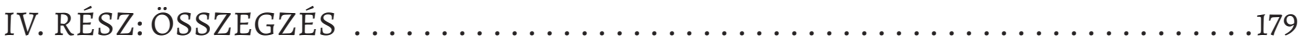

Mellékletek........................................187

1. A Római Statútum részes államai 2021-ben ...................187

2. A Nemzetközi Büntetőbíróság elótti eljárás megindítása

a Római Statútum 13. cikk b) pontja alapján ................ 188

3. A Nemzetközi Büntetôbíróság sui generis joghatósági rendszere

az agresszió büncselekménye felett a Római Statútum 15bis

és 15 ter cikkei alapján. ................................189

4. Az immunitásprobléma horizontális és vertikális hatályának szemléltetése . . 190

Felhasznált források és irodalom. . . . . . . . . . . . . . . . . . . . 191

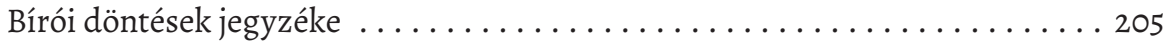

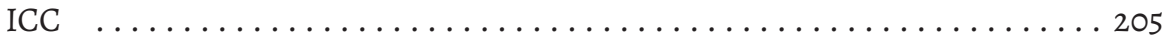

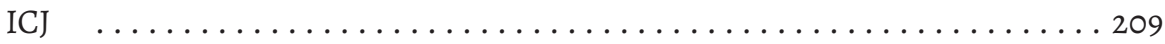

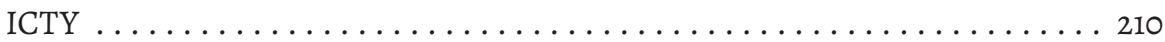

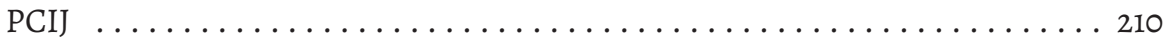

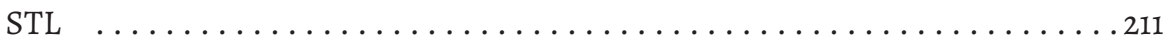

Egyéb bírói fórumok ................................

A szerző témához kapcsolódó publikációi .......................213 



\section{Előszó és köszönetnyilvánítás}

Jelen monográfia alapjául a 2020 novemberében, ugyanezen cím alatt megvédett PhD-értekezésem szolgált, annak aktualizált változatát tarthatja most kezében az olvasó. Minthogy mára már be kellett látnom, hogy kész mú nincs, legfeljebb pillanatnyi lezárás - vagy úgy is megfogalmazhatjuk sokévnyi kutatómunka távlatából, hogy a téma elengedése -, e monográfia sem kínálhat többet annál, hogy látleletet nyújt a kortárs nemzetközi jog két meghatározó szereplőjének, az Egyesült Nemzetek Biztonsági Tanácsának és a Nemzetközi Büntetóbíróságnak a kapcsolatáról.

A jogtudományról általában véve elmondható, hogy állandó mozgásban van, folyton változik, és ez különösen igaz a nemzetközi (büntető)bíróságok joggyakorlatára: a megválaszolásra váró jogkérdések száma végtelen, és e sokadalmat csak még inkább bonyolítja egy olyan viszonyrendszer, ahol a független és pártatlan bíróságnak a globális politika árnyékában kell igazságot szolgáltatnia. Ahogyan arról az olvasó oldalakkal később maga is meggyőződhet majd, a kutatás során sokszor találkoztam patthelyzetekkel, azaz olyan példákkal, amikor a politika igencsak szúkre szabta az ICC mozgásterét, vagy éppen pillanatokra meg is bénította. Ám a Nemzetközi Büntetôbíróság neve elé nem hiába teszik oda gyakorta az „állandó” jelzőt: a bírói fórum nemcsak létében állandó, hanem küzdelme és helytállása is a büntetlenség kultúrája elleni küzdelemben. Az ICC lényege (részben) abban áll, hogy velünk marad, és próbál a nemzetközi jogrendben hosszú távra berendezkedni, feladatait pedig a legmagasabb hatásfokkal ellátni. Úgy hiszem, hogy az efféle csillagzat alatt álló kutatási területre szokták azt mondani, hogy „hálás téma”, és szerencsésnek mondhatom magam azért, hogy kutatói útkeresésem elején megtalált. Mindennek ellenére e mú megszületéséhez nyilván sokkal többre volt szükség - s bár a borítón csak a saját nevem szerepel, a kötet nem jelenhetett volna meg kedves kollégáim tevékeny közremúködése nélkül, akiket e helyütt név szerint is kiemelek.

Így mindenekeloott szeretnék köszönetet mondani a jelen monográfia alapjául szolgáló PhD-értekezés megírása során nyújtott fáradhatatlan segítségéért egykori témavezetőmnek, Dr. Raisz Anikónak. Úgyszintén kitüntetett hálával tartozom Prof. Dr. Kovács Péternek a dolgozat elkészítéséhez adott szakmai tanácsaiért és a munkafolyamat valamennyi fázisa során tanúsított erőt adó támogatásáért. A legőszintébb köszönetem illeti az említett dolgozat mühelyvitáján, illetve nyilvános védésén elhangzó opponensi véleményeiért, e kötet lektorálásáért, valamint számtalan hasznos meglátásáért és kiváló ötleteeért Dr. Ádány Tamás Vincét és Prof. Dr. Sulyok Gábort. Köszönöm Dr. Domaniczky Endrének, Dr. Kecskés Gábornak, Dr. Marinkás Györgynek, Turkovicsné Dr. Nagy Adriennek, Dr. Szalai Anikónak, Dr. Szalayné Prof. Dr. Sándor 
Erzsébetnek, Dr. Varga Rékának és Prof. Dr. Wopera Zsuzsának a fokozatszerzési eljárásomban való részvételüket, támogatásukat, javaslataikat, bátorításukat, a sok-sok jó tanácsot. Végül, de nem utolsósorban pedig hálás köszönetemet szeretném kifejezni Prof. Dr. Nagy Zoltánnak és Prof. Dr. Szilágyi János Edének a támogató szakmai háttér megteremtéséért, továbbá azért, hogy e kötet kiadását lehetővé tették számomra. 


\section{Lektori ajánlás Béres Nóra: A Biztonsági Tanács által a Nemzetközi Büntetőbiróság elé utalt helyzetek legfontosabb jogi problémái címü monográfiájához}

Amikor 1998-ban a római diplomáciai konferencián részt vevő államok túlnyomó többsége a Nemzetközi Büntetőbíróság statútumának elfogadása és így egy, immár állandó nemzetközi büntető igazságszolgáltatási szerv létrehozása mellett szavazott, történelmi tettet hajtott végre. A népirtás, az emberiesség elleni bủncselekmények, a háborús bủncselekmények és az agresszió bủncselekményének elkövetése esetén immár rendelkezésre áll egy olyan állandó igazságszolgáltatási szerv, amely az elkövetők felelősségre vonását elvégzi, ha az állampolgárság vagy az elkövetés helye szerinti állam erre nem képes vagy nem kész.

Ugyanakkor az államok Rómában ugyanúgy, mint annyi más nemzetközi értekezleten, nem feledkeztek meg a realitásokról és főleg saját érdekeik érvényesítéséről. Így számoltak azzal, hogy nem minden állam lesz azonnal a Nemzetközi Büntetőbíróság statútumának részese, sőt esetleg a csatlakozás hosszú időn át várat magára. Azok az államok, amelyek pedig az Egyesült Nemzetek Szervezetének 1945. évi megalakítása óta a Biztonsági Tanács állandó tagjaiként meghatározó szerepet játszanak a világszervezet tevékenységében, tevésében és esetenként fájdalmas nem tevésében, ezt a pozíciót a nemzetközi jog hatályos koordináta-rendszerére való hivatkozással érvényesíteni törekedtek a Római Statútum megfogalmazása során is.

Így jött létre az a számos állam, politikus és szakértő által folyamatosan bírált, de ugyanúgy legalább annyi állam, politikus és az ő szakértőik által védett vagy a jelenlegi helyzetben megkerülhetetlennek tartott konstrukció, amelyben a Biztonsági Tanács még a Római Statútumban nem is részes államban elkövetett bûncselekmények miatt eljárást kezdeményezhet, ugyanakkor bizonyos esetekben - ideiglenesen - fel is függesztheti az eljárást. A politikai és szakirodalmi kritikák arra fókuszáltak, hogy vajon a Biztonsági Tanács állandó tagjai részesei lesznek-e a Római Statútumnak? Tud-e majd a Biztonsági Tanács politikai érdekektől mentesen dönteni? Ha pedig aktívan gyakorolja hatásköreit, azzal nem veszélyezteti-e az ICC függetlenségét és pártatlanságát?

Ezt a problémakört dolgozza fel részletesen a Miskolci Egyetemen megvédett disszertációja alapulvételével Dr. Béres Nóra. A szerző a széles körú szakirodalmi bázis feldolgozása 
mellett felhasználta a nemzetközi büntetőbírósági joggyakorlat vonatkozó részét, és az olvasó ennek alapján nemcsak azt érti meg, hogyan épülnek egymásra a különböző döntések, de azt is, hogy milyen nem jogi hátterú okok magyarázzák azt, hogy a Biztonsági Tanács még az általa kezdeményezett eljárásokban is habozott azt illetően, hogy a saját szankciós mechanizmusaival kényszerítse ki az ICC által kibocsátott letartóztatási parancsok végrehajtását. Bár egyelőre csak két helyzetet (ti. a líbiait és a szudánit) terjesztett a Biztonsági Tanács a Nemzetközi Büntetőbíróság elé, az ezek elemzése alapján levont következtetések jelentős mértékben vonatkoztathatók az ICC joggyakorlatának egyéb területeire is.

Jelentős teret szentel a mú annak, hogy az akkor még hatalmon levő - azóta már hatalmától megfosztott és börtönbe került - Omar al-Bashír szudáni államfó ellen kibocsátott letartóztatási parancs ügyében milyen érvekkel indokolták az ICC bírái, hogy az államfói immunitás tiszteletben tartásának hagyományos, a nemzeti alkotmányokban élő és a nemzetközi szokásjogban is elismert elve miért nem jelenti akadályát a Nemzetközi Büntetőbíróság előtt a Biztonsági Tanács által kezdeményezett eljárásnak akkor sem, ha az illető állam nem részese a Római Statútumnak. De jól láttatja az elemzés azt is, hogy a határozatok jogi érveivel szemben a regionális szolidaritás politikája miért bizonyulhatott erősebbnek, különösen akkor, amikor maguk a Biztonsági Tanács állandó tagjai sem tudtak egyetértésre jutni abban, hogy mit is akarnak elérni a megindított eljárással.

A monográfiának a részes államok együttmúködési kötelezettségét, a kétszeres büntető eljárás tilalmának (ne bis in idem re) értelmezését, a kiegészítő joghatóság (az ún. komplementaritás) szabályainak érvényesülését, a hazai felelősségre vonás elmaradásának a nemzeti nyomozás és büntető igazságszolgáltatás múködési bénultságával való összefüggéseinek vizsgálatát tárgyaló fejezetei segítenek abban, hogy az olvasó megértse, mi az, amire számíthat, és mi az, amit remélhet a Nemzetközi Büntetőbíróságtól.

A könyv tehát két szempontból is érdemes az olvasó figyelmére. Egyrészt érinti a világpolitikai összefüggéseket (ti. hogyan múködik és hogyan kellene múkködnie a Biztonsági Tanácsnak, amikor szembesül népirtással, emberiesség elleni büncselekményekkel és háborús bûncselekményekkel, agresszióval), másrészt pedig bemutatja az ICC eddigi joggyakorlatának a tárgykörbe vágó tényleges eredményeit, nem hallgatva el a bal- és félsikereket sem, rámutatva nemcsak azoknak a Nemzetközi Büntetőbíróságban rejló, a Római Statútum megfogalmazásaiból is eredő okaira, de azokra is, amelyek attól függetlenek, ám szorosan kötődnek az immár hetvenöt éves világpolitikai realitásokhoz. Egy nemzetközi jogász pedig tudja, hogy a realitásokat lehet és kell is bírálni, de nem lehet azokat nem létezőnek tekinteni.

A Nemzetközi Büntetôbíróság múködési alapelveinek és joggyakorlatának ismerete nemcsak azok számára fontos, akik a magyar honvédség és a magyar ügyészi és nyomozati szervek nemzetközi együttmúködését szervezik vagy éppen külföldi missziókat teljesítenek. 
Fontos mindazok számára, akik egyetértenek azzal, hogy a legsúlyosabb nemzetközi bủncselekmények, mint a népirtás, emberiesség elleni bûncselekmények, háborús búncselekmények, agresszió, ne maradhassanak büntetlenek.

A könyv letétele után az olvasó számára nemcsak az lesz világos, hogy a Biztonsági Tanács következetes és hatékony fellépése mely területeken tud sokat segíteni a Római Statútum céljainak megvalósításában, de arra is ráérez, hogy a jelenlegi, kontinenseken átívelő nagy migrációs mozgások mögött az egyik kiemelkedően fontos okként ott van az is, hogy a büntetlenségben és fôleg a saját megbüntethetetlenségükben bízó állami vezetők, tábornokok és polgárháborúk helyi hadurai azt hiszik, bármit megtehetnek. A római diplomáciai konferencián részt vevő államok egyetértettek abban, hogy a Nemzetközi Büntetőbíróság felállítása abba az irányba mutat, hogy ezek a személyek immár ne bízhassanak abban, hogy nem lesz felelősségre vonás, valósuljon az meg otthon vagy más országban, vagy Hágában, az ICC elött.

Ezért a Mádl Ferenc Összehasonlító Jogi Intézet fontos lépést tesz a nemzetközi közjog és a nemzetközi büntetőjog népszerúsítése érdekében, amikor a külpolitikai kérdések iránt érdeklődő szélesebb olvasóközönség számára is elérhetővé teszi Dr. Béres Nóra munkáját a Mádl Ferenc Intézet Tudományos Közleményei sorozatban.

Prof. Dr. Kovács Péter DSc egyetemi tanár, Pázmány Péter Katolikus Egyetem Jog- és Államtudományi Kar bíró, Nemzetközi Büntetőbíróság (2015-2024) Hága, 2021. május 16. 


\section{Rövidítések jegyzéke}

\begin{tabular}{|c|c|c|}
\hline ACJHR & African Court of Justice and Human Rights & $\begin{array}{l}\text { Ember és Népek Jogainak Afrikai } \\
\text { Bírósága }\end{array}$ \\
\hline ASP & $\begin{array}{l}\text { Assembly of States Parties of the Rome } \\
\text { Statute }\end{array}$ & $\begin{array}{l}\text { a Római Statútum Részes Államainak } \\
\text { Közgyuúlése }\end{array}$ \\
\hline $\mathrm{AU}$ & African Union & Afrikai Unió \\
\hline $\mathrm{BT}$ & United Nations Security Council & $\begin{array}{l}\text { az Egyesült Nemzetek Szervezete Biz- } \\
\text { tonsági Tanácsa }\end{array}$ \\
\hline DRC & Democratic Republic of the Congo & Kongói Demokratikus Köztársaság \\
\hline ECCC & $\begin{array}{l}\text { Extraordinary Chambers of the Courts of } \\
\text { Cambodia }\end{array}$ & $\begin{array}{l}\text { a Kambodzsai Bíróságok Különleges } \\
\text { Kamarái }\end{array}$ \\
\hline ENSZ & United Nations & az Egyesült Nemzetek Szervezete \\
\hline ICC & International Criminal Court & Nemzetközi Büntetőbíróság \\
\hline ICJ & International Court of Justice & Nemzetközi Bíróság \\
\hline ICTR & $\begin{array}{l}\text { International Criminal Tribunal for } \\
\text { Rwanda }\end{array}$ & $\begin{array}{l}\text { Ruandai Nemzetközi Büntető } \\
\text { Törvényszék }\end{array}$ \\
\hline ICTY & $\begin{array}{l}\text { International Criminal Tribunal for the } \\
\text { Former Yugoslavia }\end{array}$ & $\begin{array}{l}\text { Exjugoszláv Nemzetközi Büntető } \\
\text { Törvényszék }\end{array}$ \\
\hline ILC & International Law Commission & $\begin{array}{l}\text { az Egyesült Nemzetek Közgyúlésének } \\
\text { Nemzetközi Jogi Bizottsága }\end{array}$ \\
\hline ILO & International Labour Organization & Nemzetközi Munkaügyi Szervezet \\
\hline IRMCT & $\begin{array}{l}\text { International Residual Mechanism for } \\
\text { Criminal Tribunals }\end{array}$ & $\begin{array}{l}\text { Nemzetközi Büntető Ügyek } \\
\text { Mechanizmusa }\end{array}$ \\
\hline JEM & Justice and Equality Movement & $\begin{array}{l}\text { a szudáni Igazságért és Egyenlőségért } \\
\text { Mozgalom }\end{array}$ \\
\hline KGY & United Nations General Assembly & $\begin{array}{l}\text { az Egyesült Nemzetek Szervezete } \\
\text { Közgyúlése }\end{array}$ \\
\hline NGO & non-governmental organization & nem kormányközi szervezet \\
\hline PCIJ & Permanent Court of International Justice & Állandó Nemzetközi Bíróság \\
\hline PPJNE & $\begin{array}{l}\text { International Covenant on Civil and Poli- } \\
\text { tical Rights }\end{array}$ & $\begin{array}{l}\text { Polgári és Politikai Jogok Nemzetközi } \\
\text { Egyezségokmánya }\end{array}$ \\
\hline SCSL & Special Court for Sierra Leone & Sierra Leone-i Különleges Bíróság \\
\hline
\end{tabular}




\begin{tabular}{|l|l|l|}
\hline SLA & Sudan Liberation Army & Szudáni Felszabadító Hadsereg \\
\hline STL & Special Tribunal for Lebanon & Libanoni Különleges Törvényszék \\
\hline SWGCA & $\begin{array}{l}\text { Special Working Group on the Crime of } \\
\text { Aggression }\end{array}$ & $\begin{array}{l}\text { az Agresszió Búncselekményével Fog- } \\
\text { lalkozó Speciális Munkacsoport }\end{array}$ \\
\hline UNAMID & $\begin{array}{l}\text { African Union - United Nations Hybrid } \\
\text { Operation in Darfur }\end{array}$ & $\begin{array}{l}\text { az Afrikai Unió és az Egyesült Nem- } \\
\text { zetek hibrid békefenntartó múvelete } \\
\text { Dárfúrban }\end{array}$ \\
\hline
\end{tabular}



„Nem létezhet béke igazság nélkül, igazság jog nélkül, a jog létezése pedig nem bírhat valódi érdemmel egy olyan Bíróság nélkül, amely arra hivatott, hogy eldöntse, mi az, ami jogos és igazságos - történjen bármi is."

Ben Ferencz ${ }^{1}$

1 Benjamin Berell Ferencz magyar származású amerikai jogász. A születése utáni évben, amikor a trianoni szerződés Erdélyt Romániához csatolta, családja az Egyesült Államokba emigrált. A Harvard Egyetemen jogász végzettséget szerzett, majd részt vett a nácik által elkövetett háborús bủncselekmények felderítésében a második világháború után, és az amerikai hadsereg föügyészeként járt el az Einsatzgruppen-perben, a nürnbergi Nemzetközi Katonai Törvényszék előtt 1947 és 1948 között. A Nemzetközi Büntetőbíróság életre hívásának élharcosa, a nemzetközi büntető igazságszolgáltatás kulcsfigurája. Tavaly, 2020 márciusában ünnepelte 100. születésnapját. Lásd bővebben: Gut, 2020, 11. o. 



$$
\begin{gathered}
\text { I. } \\
\text { RÉSZ }
\end{gathered}
$$

\section{Bevezetés}




\section{A témaválasztás aktualitása, a könyv célja, tárgya, szerkezeti felépítése és az alkalmazott kutatásmódszertan}

A Nemzetközi Büntetőbíróság felállítása a modern nemzetközi jog egyik legjelentősebb vívmánya az ENSZ létrehozása óta. A bíróságra ruházott már-már mitologikus mandátum - azaz hogy a büntetlenség kultúrájának pajzsán éktelenkedő réseket hézag nélkül betöltse a büntetôbírói fórumot múködésének kezdetétôl fogva hatalmas elvárások elé állította. Fontos felismerni azonban, hogy az ICC rendkívül jelentős, ugyanakkor nem kizárólagos szerepet játszik a nemzetközi büntető igazságszolgáltatás színpadán: hatékony múködéséhez és a hőn áhított magasztos cél eléréséhez egyéb szereplők és egyéb mechanizmusok együttes közremúkködése szükséges, legyenek azok például az ad hoc nemzetközi büntetôbíróságok, a hibrid büntetôbírói fórumok vagy a nemzeti bíróságok előtti - akár univerzális joghatóság alapján indult - büntetőeljárások. Az ICC rendeltetésének megfelelő elhelyezése a nemzetközi jogrendben tehát kiemelkedő fontossággal bír, mert csak akkor kaphatunk reális képet róla, ha nem becsüljük alá, egyszersmind nem is látunk bele többet annál, mint amire valójában hivatott.

Noha a bíróságot csillapíthatatlan örvényként körülvevő kihívások egy része valamennyi nemzetközi büntetőbírói fórum múködését áthatja - így például a bizonyítási eljárás sajátosságai, a nemzetközi büntető igazságszolgáltatás magasra rúgó költségei, a bíróság múkködésének békefenntartásra és társadalmi konszolidációra gyakorolt mérsékelt hatásai -, a Nemzetközi Büntetőbíróságnak olyan próbatételek kereszttüzében is helyt kell állnia, amelyek kifejezetten csak rá jellemzőek. Ezen sajátos problémák okait két csokorba szedhetjük.

Az egyik ilyen „csokor”, hogy mivel az ICC-t nemzetközi szerződéssel hozták létre, a szerződések jogának - jellemzően „magánjogias” sajátosságai - a Római Statútum² teremtette keretrendszer valamennyi szegletét átjárják, és kihatással vannak a bíróság előtt folyó bűnvádi eljárások dinamikájára. Ugyanakkor a (nemzetközi) büntető igazságszolgáltatás erôteljesen „közjogias” műfaj: az állami szuverenitásból eredő büntetőhatalom gyakorlása csak akkor hatékony, ha végrehajtják az eljáró bíróság döntéseit. A szerződéses alapok pedig a nemzetközi büntetőjog jogintézményeit sok esetben nem tudják „leképezni”, azokat hatékonnyá tenni. Ez a bíróság problémáinak általános oka, melyek az ICC elötti valamennyi ügynél fennállnak. Praetor ius facere non potest - tartja az ősi római jogi maxima, s bár a jogalkotásra a nemzetközi (büntető)bírák felhatalmazása napjainkban

2 Rome Statute of the International Criminal Court, Rome, 17 July 1998. UN Doc. A/CONF. 183/9. Magyarország a Római Statútumot aláírta, ám a ratifikált nemzetközi szerződés promulgációja azóta sem történt meg. A kihirdetés elmaradásának lehetséges okairól lásd: Kovács, 2019a, 69-90. o. 
sem terjed ki, e bírói fórumok jogértelmezésben játszott szerepe különös jelentőséggel bír: a juriszdikció feladatává vált a nemzetközi büntetőjog fogalmainak óvatos kibontása, az ICC esetében pedig a büntetőjogi jogintézmények szerződéses alapokból való részletes „leképezése”. Kétségtelen, hogy utóbbi nem kis kihívás elé állítja a bíróság kéktaláros testületét, azonban azt is látnunk kell, hogy egy állandó nemzetközi büntetőbíróság létrehozásának alkalmas és legitim módjára való jobb megoldás a nemzetközi jogban jelenleg nem létezik.

A fentiek fényében a bírói joggyakorlatra jelen mủben különösen erős hangsúly esik azzal, hogy a kiválasztott jogesetek szelekciója egyetlen célt szolgál: nevezetesen, hogy bemutassa azokat a problémákat, amelyek a Biztonsági Tanács által a Nemzetközi Büntetốbíróság elé vitt helyzetek sajátjai. Ezzel elérkeztünk az ICC-t metsző sajátos kihívások másik „csokrához” - az első problémakörrel való viszonyát tekintve részhalmazához -, mely a monográfia differentia specificája is egyben. A bíróságnak ugyanis még több nehézséggel kell megküzdenie akkor, ha a BT kezdeményez előtte eljárásokat, mivel az elmúlt 18 év gyakorlatából egyértelmúen azt olvashatjuk ki, hogy ilyenkor a Római Statútumban nem részes - azaz harmadik - államok feletti joghatóság-gyakorlásáról van szó. Ez tehát a bíróság problémáinak különös oka, mely csak a BT által kezdeményezett eljárásoknál áll fenn. Ilyenkor nem pusztán arról van szó, hogy a szerződéses gyökereknek nehéz a büntetőjogot effektívvé tenniük, hanem arról is, hogy mindezt úgy kellene tenniük, hogy a Római Statútumban nem részes felekre alkalmazzák ôket. $S$ bár - a nemzetközi béke és biztonság fenntartásának imperatívusza jegyében - az ENSZ Alapokmány ${ }^{3}$ VII. fejezete alapján hozott BT-határozatok a Római Statútum relatív hatályát áttörik, az így kezdeményezett eljárásokban számos jogalkalmazási kérdés kerül a felszínre, a generált politikai feszültségről már nem is beszélve. Merthogy a Biztonsági Tanács nem igazságszolgáltatási, hanem kristálytisztán politikai szerv. Ráadásul a politikai tenzió nem csupán a bíróság elé kerülő helyzetek ICC-ig tartó útját szegélyezi, hanem végig is kíséri őket. Minthogy az afrikai kontinens az ICC „kedvenc ügyfele”, ${ }^{4}$ érdemes azt is számításba venni, hogy milyen utóhatásai vannak a BT által kezdeményezett eljárásoknak a regionális politikában, miként reagál rájuk az Afrikai Unió?

A témaválasztás aktualitásáról talán nem tủnik szerénytelenségnek azt állítani, hogy aligha nehéz róla meggyőzni az olvasót. Utóbbit alátámasztandó kiemelhető például, hogy az ICC agresszió bűncselekménye feletti joghatóság-gyakorlására vonatkozó kiegészítések hatálybalépése óta még két év sem telt el, vagy hogy az elemzett bírói döntések közül a legújabbat 2020. március 9-én hozták meg.

3 1956. évi I. törvény az Egyesült Nemzetek Alapokmányának törvénybe iktatásáról.

4 Igwe, 2008, 294-323. o. 
A kötet célja tehát, hogy bemutassa a Biztonsági Tanács által a Nemzetközi Büntetôbíróság elé utalt helyzetek gócpontjait, s hogy tegye ezt úgy, hogy rávilágít arra az ellentmondásra, ami a jogi normákban lefektetett „modell” és azok gyakorlati érvényesülése között feszül azzal, hogy már a mû́ elején leszögezi: a kutatás alapvetően ICC-fókuszú, azaz a két intézmény elemzése nem egyforma súllyal esik latba.

Jelen könyv tárgya sommásan a BT által az ICC elé vitt szituációk normatív, esetjogi és néhol politikai szemléletú elemzése. A vizsgálódás - Navi Pillay találó meglátásával összhangban - a bíróságot sújtó legyakoribb bírálatok perspektíváit öleli fel: (i) az ICC-t támogató politikai akarat hiányát; (ii) az univerzális elfogadottság hiányát; (iii) az együttmûkködési hajlandóság hiányát; (iv) a joghatóság hiányát; valamint (v) a rendelkezésre álló anyagi források hiányát. ${ }^{5} \mathrm{~A}$ kutatás tárgya determinálja, hogy a monográfiában elsősorban nemzetközi büntetô eljárásjogi - és nem anyagi jogi - kérdések kerülnek középpontba, ugyanakkor e komplex kérdéskör megértéséhez a nemzetközi jog egyéb területeit is segítségül kell hívni, így döntően a nemzetközi szervezetek jogát, a nemzetközi szerződések jogát, a nemzetközi humanitárius jogot, a „nemzetközi bíróságok jogát” és érintőlegesen az emberi jogokat.

Fontos továbbá megjegyezni, hogy a mú tárgya behatárolja a Nemzetközi Büntetôbíróság esetjogából merített ügyek eljárásjogi szempontú közös keresztmetszetét is, minthogy valamennyi, ${ }^{6}$ a BT által az ICC elé utalt helyzet egyelôre megtorpant a tárgyalás-előkészítő szakban, így e helyütt javarészt olyan bírói döntések kerülnek bemutatásra, melyek a tárgyalási szak kezdete előtt láttak napvilágot.

A kötet forráskörét a releváns hazai és külföldi szakirodalom, nemzetközi szerződések, nemzetközi bírói döntések, valamint egyéb nemzetközi dokumentumok alkotják; és mivel a téma jellegéből adódóan elsősorban angol nyelvư források állnak rendelkezésre, a mú több helyen fogalomteremtésre vagy fogalomárnyalásra tesz kísérletet. Utóbbi a monográfia alapjául szolgáló $\mathrm{PhD}$-értekezésben bemutatott kutatás egyik legnehezebb vállalkozása volt, minthogy a nemzetközi büntető anyagi jog és eljárásjog sokszor olyan fogalmakkal operál,

5 Navi Pillay nyitóbeszéde a Nürnbergben 2019. október 18-án, az International Nuremberg Principles Academy által szervezett, Nuremberg Forum 2019- The Nuremberg Principles beyond the International Criminal Court: A Common Ground for Accountability címú konferencián.

6 Jóllehet e tekintetben a közeljövőben változás várható, Ali Muhammed Ali Abd-Al-Rahman ('Ali Kushayb') dzsandzsavíd milíciavezér tavalyi bíróság elé állításának köszönhetően. Ali Kushayb azután került az ICC őrizetébe, hogy önként feladta magát a közép-afrikai hatóságoknak, melyek 2020. június 9-én átadták a gyanúsítottat a Nemzetközi Büntetôbíróságnak. A terhelt ellen két letartóztatási parancs van érvényben, 53 rendbeli emberiesség elleni, illetve háborús bưncselekményekkel vádolják. A vele szemben emelt vádak megerősítésére irányuló tárgyalássorozatot a 2. számú tárgyalás-előkészítő tanács 2021. május 24-én kezdi meg. The Prosecutor v. Ali Muhammad Ali Abd-Al-Rahman („Ali Kushayb”), ICC-02/05-01/20, Pre-Trial Chamber II. Az ügyről lásd bővebben: https://www.icc-cpi.int/darfur/abd-al-rahman [Letöltve: 2021. 04. 20.]. 
amelyek a germán-római jogcsaládtól egyébként idegenek, gondoljunk például a „referral”, „deferral”, „admissibility”, „same person / same conduct test” terminológiákra.

Ami a könyv szerkezeti felépítését illeti, négy részre és kilenc fejezetre tagolódik. Az egyes részek deduktív sorrendbe rendeződnek a Biztonsági Tanács és a nemzetközi büntető igazságszolgáltatás „első találkozásától” kiindulva egészen a BT által az ICC elé vitt helyzetekből kirajzolódott ügyek konkrét gyakorlati problémáiig.

A bevezetést követően az Alapvetés: a Biztonsági Tanács és a nemzetközi büntető igazságszolgáltatás címú 2 . fejezet célja, hogy bemutassa a Biztonsági Tanács „premierjét" a nemzetközi büntető igazságszolgáltatásban, hogy felvázolja a BT vonatkozó hatásköreinek jogszabályi kereteit az Egyesült Nemzetek Alapokmányát segítségül hívva, valamint hogy a Nemzetközi Jogi Bizottság előkészítő munkája révén testközelbe hozza a Biztonsági Tanács és az állandó Nemzetközi Büntetőbíróság kapcsolatának koncepcióját, illetve hogy felvillantson néhány, a Biztonsági Tanács és a Nemzetközi Büntetőbíróság kapcsolatára vonatkozó elméleti víziót, mintegy hidat képezve a soron következő, a két intézmény viszonyát normatív szempontból elemző II. részhez. A fejezetben alkalmazott kutatásmódszertan többrétû: egyrészt funkcionalista, tekintve, hogy a BT egyik speciális szerepének - a nemzetközi büntető igazságszolgáltatásban betöltött funkciójának - körvonalait igyekszik megvonni; másrészt normatív, hiszen e szerep értelmezéséhez az ENSZ Alapokmány VII. fejezetéből - így különösen annak 39. és 41. cikkeiből - indul ki. A 2. fejezet továbbá a történeti módszert alkalmazza, mivel a Biztonsági Tanács és a Nemzetközi Büntetôbíróság kapcsolata gyökereinek feltárásához a Római Statútum travaux préparatoires-ját használja fel.

A kötet II. része A Nemzetközi Büntetőbíróság előtti eljárás megindítása a Római Statútum 13. cikk b) pontja alapján címú 3. fejezettel indít, és ezzel kezdetét veszi a Nemzetközi Büntetôbíróság és a Biztonsági Tanács viszonyának normatív szempontú elemzése, így elsőként a Római Statútum vonatkozó rendelkezésének részletekbe menő vizsgálata. E helyütt kitüntetett figyelmet kap az ICC és a BT kapcsolatának első „pillére”, azaz a Biztonsági Tanács eljáráskezdeményező hatásköre. Az olvasó megismerkedhet továbbá a dárfúri és líbiai helyzetek Nemzetközi Büntetőbíróság elé kerülésének körülményeivel, valamint e konfliktusok társadalmi, illetve történeti kontextusával - persze csak olyan mértékben, amely a nemzetközi jogi munkák által megkívánt optimális arányokat igyekszik szem előtt tartani. A 3. fejezetben néhány olyan gyakorlati jellegú probléma - így az eljárások finanszírozásának és a nem részes államok békefenntartói feletti joghatóság-gyakorlásának kizárása, valamint az ENSZ-tagállamok együttmüködésre kötelezésének elmulasztása - is felsorakozik, melyek közül többnek a jelentősége és a komplexitása nem indokolta külön fejezetbe emelésüket a későbbiek folyamán. E fejezetben a normatív és a dogmatikai elemzés nevezhető meg uralkodó 
kutatásmódszertanként, ismételten elegyedve a történeti módszerrel a bíróság elé utalt két konfliktus, a dárfúri és a líbiai helyzetek bemutatásakor.

A monográfia A Nemzetközi Büntetôbíróság előtti eljárás megindítása a Római Statútum 15bis és 15ter cikkei alapján címú 4. fejezete az ún. kampalai módosítások tükrében vizsgálja meg az ICC agresszió búncselekménye felett gyakorolt joghatóságát, szükség szerint érintve a büntetô anyagi jogi aspektusokat is, mindazonáltal kiemelten kezelve az eljárásjogi kérdéseket és a Biztonsági Tanács „agressziós eljárásokban” játszott szerepét. Itt nemcsak a BT eljáráskezdeményező hatásköre tükrében kerül az „agressziós eljárás” górcső alá, hanem a részes államok és a bíróság föügyészének eljáráskezdeményezésének fényében is, mivel utóbbiak során a Biztonsági Tanács szintén fontos szerephez jut az „agresszió cselekményének" elózetes megállapítása miatt. A 4. fejezet alkalmazott kutatásmódszertana szintén a normatív és a dogmatikai módszerre szorítkozik, többek között azért, mert a 2018. július 17-én hatályba lépett, agresszióra vonatkozó kiegészítő rendelkezések gyakorlati alkalmazására napjainkig nem került sor, így az esetjogi kutatásmódszertanra e helyütt nem lehetett támaszkodni.

A könyv A Nemzetközi Büntetôbíróság előtti nyomozás vagy büntetőeljárás felfüggesztése a Római Statútum 16. cikke alapján címú 5. fejezete a normatív kereteket bemutató II. rész utolsó szerkezeti egysége, mely a Biztonsági Tanács eljárásfelfüggesztő hatáskörére fókuszál, azaz az ICC és a BT kapcsolatának második, „negatív pillérére”. E fejezet továbbá körbejárja a 16. cikk gyakorlati alkalmazásával, illetve a gyakorlati alkalmazás „kísérleteivel” előidézett jogi dilemmákat, ismételten a normatív, dogmatikai és esetjogi kutatásmódszertant segítségül hívva.

A kötet 6. fejezete - A Nemzetközi Büntetőbíróság és harmadik államok - nyitja az ICC és a BT kapcsolatának gyakorlati problémáira fókuszáló III. részt. A fejezet a későbbi logikai építkezés megkerülhetetlen előfeltétele, azaz deduktív alapvetés, probléma-kronologikus lépés a soron következő fejezetek megértéséhez, amelyekben olyan specifikus kérdésekról van szó, amelyek kifejezetten harmadik államokhoz kapcsolódnak. Bár a Római Statútumban erre való utalást sehol sem találunk, a Biztonsági Tanács eljáráskezdeményező hatáskörét ez idáig mindkétszer olyan államokkal szemben gyakorolta, amelyek nem részes felek a Nemzetközi Büntetőbíróság statútumában. A 6. fejezet kutatásmódszertana a 4. fejezetével megegyezik.

A monográfia A komplementaritás és a Biztonsági Tanács által kezdeményezett eljárások címú 7. fejezete a Római Statútum egyedi joghatóságmodelljével, a komplementaritás érvényesülésével foglalkozik a BT által kezdeményezett eljárások sajátosságait figyelembe véve, ehhez pedig a líbiai helyzetet hívja segítségül. A fejezet koncepciója a komplementer joghatóság nemzetközi jogrendben elfoglalt unikális jellegéből indul ki, és azzal a céllal szövi a gondolatmenetét, hogy mélyrehatóan megismertesse az olvasót az ICC joggyakorlatával, 
nem rejtve véka alá azokat az ellentmondásokat, amelyek a büntetőbírói fórum esetjogát helyenként jellemzik, ezzel párhuzamosan rámutatva a legutóbbi joggyakorlat üdvözlendő nóvumaira is. A komplementaritás elemzésénél a fogalomelemző, esetjogi és jog-összehasonlító módszerek kerülnek túlsúlyba.

A könyv III. részének utolsó, Az együttmúködés, a nemzetközi elfogatóparancsok végrehajtása és a Biztonsági Tanács által kezdeményezett eljárások címú 8. fejezete az ICC-vel való együttmû́ködés és a bíróság határozatai végrehajtásának hiányát állítja középpontba, különös tekintettel az államfői immunitás kérdésére. Utóbbi leginkább a történeti, fogalomelemző, normatív, jog-összehasonlító és jogesetelemző módszereket ötvözi. Utóbbi kapcsán a fejezet nemcsak a Nemzetközi Büntetőbíróság joggyakorlatából merít, hanem számos egyéb nemzetközi és nem nemzetközi bírói fórum - így például az ICTY, az SCSL vagy a Nemzetközi Bíróság - vonatkozó döntéseit is elemzi.

Végezetül a kötet Összegzés címú IV. részében a következtetések és a zárógondolatok foglalnak helyet, tételesen sorra véve a kutatás során felállított téziseket.

Jelen monográfia tehát arra a keresi a választ, hogy (i) miképpen kapcsolódik be a Biztonsági Tanács a nemzetközi büntető igazságszolgáltatásba; (ii) milyen normatív koordináták jelölik ki az ICC és a BT kapcsolatát; (iii) ezek hogyan érvényesülnek, milyen gócpontok jelennek meg a gyakorlatban; (iv) hogyan értelmezi a bírói joggyakorlat e két intézmény kapcsolatát, milyen esetjogi következtetéseket lehet levonni; és végül (v) hogy milyen politikai tényezők hatnak a Nemzetközi Büntetőbíróság és a Biztonsági Tanács kapcsolatára?

\section{Alapvetés: a Biztonsági Tanács és a nemzetközi büntető igazságszolgáltatás}

\subsection{A Biztonsági Tanács megjelenése a nemzetközi büntető igazságszolgáltatásban}

Az elsődleges felelősséget a nemzetközi béke és biztonság fenntartásáért a Biztonsági Tanács viseli - következik az Egyesült Nemzetek Alapokmányának 24. cikk (1) bekezdéséből, ${ }^{7}$ mint ahogyan az is, hogy a BT e felelősségéből folyó kötelezettségeinek teljesítésekor az ENSZ tagállamainak ${ }^{8}$ nevében jár el. A nemzetközi béke és biztonság fenntartása minden

7 ENSZ Alapokmány 24. cikk (1) bekezdés: „A Szervezet gyors és hathatós cselekvésének biztositása érdekében a tagok a nemzetközi béke és biztonság fenntartásáért a fófelelösséget a Biztonsági Tanácsra ruházzák és elismerik, hogy a Biztonsági Tanács e felelősségból folyó kötelességeinek teljesitésekor az ő nevükben jár el."

8 Az ENSZ-nek jelenleg 193 tagállama van. A tagállamok listáját lásd: https://www.un.org/en/about-us/member-states [Letöltve: 2021.04 .20 .]. 
bizonnyal a legfontosabb az ENSZ céljai közül, melyet jól példáz az Alapokmányban elfoglalt helye is: az erről szóló rendelkezést az 1. cikk (1) bekezdésében találhatjuk.

Annak érdekében, hogy a Biztonsági Tanács valóban gyorsan és hathatósan léphessen fel a békét veszélyeztető, megsértő, illetve agressziót elkövető államokkal szemben, az ENSZ Alapokmány VII. fejezete rendkívül kiterjedt hatáskörökkel ruházza fel. Emellett az Alapokmány 25. cikke rögzíti a heteronormatív BT-határozatok kötelező erejét a tagállamokra nézve, azaz hogy „a Szervezet tagjai megegyeznek abban, hogy a Biztonsági Tanács határozatait a jelen Alapokmánynak megfelelően elfogadják és végrehajtják". A BT-határozatok tehát általában véve kötelezik az ENSZ tagállamait, kivéve, ha a Biztonsági Tanács egyértelmúen ajánlást fogad el. E vélelmet a Nemzetközi Bíróság a Dél-Afrika folyamatos namíbiai jelenlétébôl az államokra háruló jogkövetkezmények tárgyában adott tanácsadó véleményében ${ }^{10}$ állította fel 1971ben, melynek jelentőségét Bruhács János szavaival élve az adja, hogy „a Biztonsági Tanács általában tartózkodik attól, hogy határozatában az Alapokmány meghatározott cikkére hivatkozzon, sőt az ajánlási jellegre utaló szavakat (kér, óhajt stb.) összeköti a határozathoz való alkalmazkodásra vonatkozó felhivással". ${ }^{11}$

A „nemzetközi béke és biztonság” fogalmát az ENSZ Alapokmányban nem találhatjuk meg, mint ahogyan a háború törvényeire és szokásaira sem történik benne utalás. E mulasztás szándékos, mivel az Alapokmány kodifikációja során az a nézet kerekedett felül, hogy bármiféle hivatkozás a ius ad bellumra vagy ius in bellóra azt a benyomást erősítheti, hogy a 2. cikk (4) bekezdésben ${ }^{12}$ megfogalmazott erőszak-tilalom és a kollektív biztonság rendszerét szolgáló mechanizmusok felállítása mind hiábavalók, a fegyveres összeütközéseket úgysem lehet megakadályozni. ${ }^{13}$ Továbbá akármilyen figyelmesen olvassuk is végig az ENSZ Alapokmányának Eljárás a béke veszélyeztetése, a béke megszegése és támadó cselekmények esetében címú fejezetét, és akármeddig is keressük benne, nem fogunk a nemzetközi büntető igazságszolgáltatásra vonatkozó jogszabályhelyeket találni. Mindazonáltal kétség sem férhet hozzá, hogy a Biztonsági Tanács az utóbbi három évtizedben

9 ENSZ Alapokmány 1. cikk (1) bekezdés: „Az Egyesült Nemzetek célja, hogy fenntartsa a nemzetközi békét és biztonságot és e végből hathatós együttes intézkedéseket tegyen a békét fenyegetö cselekmények megelőzésére és megszüntetésére a támadó cselekményeknek vagy a béke más módon történő megbontásának elnyomására, valamint békés eszközökkel, az igazságosság és a nemzetközi jog elveinek megfelelö módon rendezze vagy megoldja azokat a nemzetközi viszályokatés helyzeteket, amelyek a béke megbontására vezethetnek."

10 Legal Consequences for States of the Continued Presence of South Africa in Namibia (South West Africa) notwithstanding Security Council Resolution 276 (1970), Advisory Opinion of 21 June 1971, I.C.J. Reports 1971, $\$ \$ 112-114$.

11 Bruhács, 2001, 57. 0.

12 ENSZ Alapokmány 4. cikk (2) bekezdés: „A Szervezet összes tagjainak nemzetközi érintkezéseik során más Állam területi épsége, vagy politikai függetlensége ellen irányuló vagy az Egyesült Nemzetek céljaival össze nem férö bármely más módon nyilvánuló erőszakkal való fenyegetéstől vagy erőszak alkalmazásától tartózkodniok kell."

13 Roscini, 2010, 332. o. 
főszerepet játszott a nemzetközi büntető igazságszolgáltatás színpadán. Ennek demonstrálása igencsak egyszerúnek túnik, ha számba vesszük az ezen idôszak alatt létrehozott nemzetközi büntetőbírói fórumok népes táborát és a $\mathrm{BT}$ részvételét a törvényszékek felállításában.

Az ENSZ főszerve elsőként ${ }^{14}$ 1993-ban lépett e képzeletbeli színpadra, amikor is 827. (1993) határozatával ${ }^{15}$ megalkotta az Exjugoszláv Nemzetközi Büntető Törvényszéket. A BT által alkalmazott jogtechnikai megoldás - tudniillik hogy politikai szervként az érintett állam hozzájárulása nélkül visszaható hatállyal büntető joghatóságot „teremtett" a felbomlott Jugoszlávia utódállamai felett, ráadásul tette mindezt úgy, hogy erre az ENSZ Alapokmánya nem ad számára expressis verbis felhatalmazást ${ }^{16}$ - a '90-es évek hajnalán formabontó és meglepő lépésnek számított, s mint ilyen, rengeteg bírálatot és jogi elemzést vont maga után. ${ }^{17} \mathrm{Az}$ már csak olaj volt a tủzre, amikor a BT egy évvel később újabb nemzetközi büntetőbíróságot állított fel: a 955. (1994) határozattal ${ }^{18}$ megalakult a Ruandai Nemzetközi Büntető Törvényszék. A két büntetőbírói fórum egymással mondhatni "testvéri kapcsolatban” állt, mivelhogy nemcsak létrehozásuk módjában, hanem müködésükben is nagyon hasonlítottak egymáshoz - olyannyira, hogy a két bíróság fellebbviteli tanácsa megegyezett. Mindazonáltal az ad hoc büntető törvényszékek felállítása ${ }^{19}$ szimbolikus jelentőségének és joggyakorlat-forradalmasító jellegének dacára nem válhatott hosszú távon fenntartható és bevett megoldássá, melynek elsődleges okai a létrehozásuk módjával gerjesztett legalitáshoz kapcsolódó kihívásokban és múködtetésük költségeiben rejlettek. ${ }^{20}$

14 A skóciai Lockerbie felett 1988-ban terrorista merénylet áldozatául esett utasszállító repülőgép lezuhanásával gyanúsított elkövetők felelősségre vonása céljából felállított ad hoc törvényszék esetét ide nem értve, jóllehet nemzetközi jogi értelemben e bíróság nem nemzetközi bủncselekmények felett gyakorolt joghatóságot. Lásd: Simma et al., 2012, 1319. o.

15 UN Doc. S/RES/827 (25 May 1993).

16 Érdekességként említhető meg, hogy az ICTY és az ICTR joghatóságát nem a személyi, hanem az időbeli és a tárgyi hatály mentén haladva vonták meg. Lásd: Ádány, 2018, 533. o.

17 Ezek fő csapásirányai a Biztonsági Tanács hatáskörének és a törvényszékek felállítása jogszerűségének hiányában, valamint a tisztességes eljáráshoz való jog sérelmében öltöttek testet. Lásd: Reinisch, 2009, 263-264.

18 UN Doc. S/RES/955 (8 November 1994).

19 A törvényszékek létrehozásának e sajátos módjával egyrészt el tudták kerülni, hogy éppen a gyanúsítottak állampolgársága szerinti államok ne fogadják el a bíróságok statútumát, másrészt meg tudták valósítani, hogy a konfliktusok szorításában időhiánnyal küzdő ENSZ a nemzetközi béke és biztonság megsértésére hathatósan reagáljon. Lásd: Kovács, 2018 [Online].

20 Az ICTY általános költségvetése 2010-2011 között 286012 600, 2012-2013 között 250 814 000, 2014-2015 között 179998600 amerikai dollárt tett ki. Lásd: https:/www.icty.org/en/about/tribunal/the-cost-of-justice [Letöltve: 2020. 01. 02.]. 
Így az ENSZ új fejezetet nyitott a büntetô törvényszékek történelemkönyvében, és elhozta a hibrid büntetôbíróságok korszakát. ${ }^{21}$ Utóbbiak olyan koncepció képében jelentek meg, ami az ad hoc törvényszékek csorbáit hivatott kiküszöbölni. Mindazonáltal kulcsfontosságú tényező, hogy a hibrid mechanizmusok többségének - így például a Sierra Leone-i Különleges Bíróságnak vagy a Kambodzsai Bíróságok Különleges Kamaráinak - létrehozásában az érintett országok posztkonfliktusos kormányzatának közbenjárása és az állami hozzájárulás adott volt. Ezáltal a hibrid törvényszékek felállítása általában véve kevésbé vetett fel legalitással kapcsolatos aggályokat - a Libanoni Különleges Törvényszéket leszámítva. Az STL esete azért kirívó, mert az ENSZ és Libanon kormánya által közösen egyeztetett statútumtervezettől az ország parlamentje a ratifikációt az utolsó pillanatban megvonta, így a bíróság alapszabályát a BT 1757. (2007) határozata léptette hatályba. ${ }^{22}$ E sajátos aktus nem kis fejtörést okozott a jogalkalmazónak, hiszen újfent megjelent a védelem oldalán a törvényszék legalitását kétségbe vonó retorika. ${ }^{23}$

Utóbbi annál kritikusabb, minél inkább közremúködött a BT a büntetőbírói fórum létrehozásában. Ha egy képzeletbeli skálát állítunk fel, akkor egyik végpontjába a megadott állami konszenzuson alapuló nemzetközi szerződéssel létrejövő bíróságokat (például SCSL, ECCC és az ICC elötti egyes helyzetek) ${ }^{24}$ kell állítanunk, másik végpontjába pedig a külső

21 Jóllehet a nemzetközi büntetőbíróságok békefenntartásra gyakorolt hatásai a szakirodalomban meglehetősen vitatottak. Egyes nézetek szerint felmerül annak kockázata, hogy az egyébként beavatkozni képes államok a nemzetközi büntető igazságszolgáltatás „palástja” mögé bújva a válságkezelésnek e kevésbé költséges, ugyanakkor adott helyzetben nem elég gyors vagy nem elég effektív módját választják. Emellett az is lehetséges, hogy a beavatkozni képes államok a békefenntartókat egy esetleges nemzetközi büntetőeljárástól féltve szintén a be nem avatkozást preferálják, illetve hogy a humanitárius intervenciót a bírói út egyidejú vagy utólagos igénybevételével próbálják meg legitimmé tenni. Lásd bővebben: Fehl, 2014 [Online]; Sulyok, 2003, 41-43. o.

22 UN Doc. S/RES/1757 (30 May 2007).

23 Utóbbi az ún. Ayyash és mások-ügy központi kérdése volt azzal, hogy még az első- és másodfokú bírói tanácsok véleménye sem egyezett a kérdésben, mi több, a fellebbviteli ítélethez ketten is - beleértve a tanácselnököt különvéleményt csatoltak. Lásd: Procedural Decision on Defence Motions Challenging, The Prosecutor v. Salim Jamil Ayyash et al. (STL-11-01/PT/TC), Trial Chamber, 18 May 2012; Decision on the Defence Appeals against the Trial Chamber's "Decision on the Defence Challenges to the Jurisdiction and Legality of the Tribunal", The Prosecutor v. Salim Jamil Ayyash et al. (STL-11-01/AC/AR90.1), Appeals Chamber, 24 October 2012; Separate and Partially Dissenting Opinion of Judge Baragwanath, Decision on the Defence Appeals against the Trial Chamber's "Decision on the Defence Challenges to the Jurisdiction and Legality of the Tribunal", The Prosecutor v. Ayyash et al. (STL-11-01/AC/AR90.1), Appeals Chamber, 24 October 2012; Separate and Partially Dissenting Opinion of Judge Riachy, Decision on the Defence Appeals against the Trial Chamber's "Decision on the Defence Challenges to the Jurisdiction and Legality of the Tribunal", The Prosecutor v. Ayyash et al. (STL-11-01/AC/AR90.1), Appeals Chamber, 24 October 2012.

24 A Biztonsági Tanács szerepe a SCSL létrehozásában is megkérdőjelezhetetlen volt: megbízta az ENSZ fôtitkárát az előzetes tárgyalások lefolytatásával, kijelölve a bíróság joghatóságának ideális sarokpontjait, továbbá támogatta a nem Sierra Leone-i állampolgárok és az egykori libériai elnök, Charles Taylor felelősségre vonását is. Az ECCC-vel kapcsolatban e ponton annyit kell felvillantani, hogy Kambodzsa hozzájárulását a Biztonsági Tanács nyomásával „belengett” politikai környezetben adta meg. Lásd: Mégret, 2008, 502. o. 
kényszert, mely a Biztonsági Tanács határozatainak formájában jelenik meg (mint például az ICTY vagy az ICC előtti dárfúri és líbiai helyzet esetén). A skála közepén helyezkedik el az STL és az ICTR, minthogy előbbi esetén a BT határozata az állami közremúködéssel megszövegezett bilaterális megállapodást „csak” hatályba léptette, ${ }^{25}$ utóbbi esetén pedig Ruanda a törvényszék felállításának kezdeti fázisában - 1994 és 1995 között - a BT nem állandó tagjaként tevékenyen részt vett.

Jóllehet a nemzetközi büntetôbíróságok proliferációja ${ }^{26}$ nem korlátozódik az e helyütt megemlített bírói fórumokra, jogtörténeti szempontból csupán az ICTY és az ICTR emelhető ki „előképekként” ezen intézmények sokaságából, mivel az ad hoc törvényszékek által gyakorolt büntető joghatóságot a Biztonsági Tanács egy-egy határozata alapozta meg, csakúgy, mint az e kötet szúkebb értelemben vett tárgyát képező ICC előtti helyzetekben. Mint ahogyan az a későbbiekben láthatóvá válik majd, a Biztonsági Tanács eljáráskezdeményező határozatai ipso iure megalapozzák az ICC joghatóságát, és „életre keltik” olyan szituációkban, amikor az harmadik államok esetén egyébként nem állhatna fenn.

\subsection{A nemzetközi büntetőigazságszolgáltatás normatív gyökerei az Egyesült Nemzetek Alapokmányában}

A nemzetközi büntető igazságszolgáltatás normatív gyökereinek feltárásához elsőként az ENSZ Alapokmányának 39. cikkét és 41. cikkét szükséges alaposan szemügyre venni.

Az Egyesült Nemzetek Alapokmányának 39. cikke - melyet a szakirodalomban az Alapokmány legfontosabb rendelkezéseként tart számon ${ }^{27}$ - kimondja, hogy „a Biztonsági Tanács megállapítja a béke bárminő veszélyeztetésének vagy megszegésének, vagy bárminő támadó cselekménynek fennforgását és vagy megfelelő ajánlásokat tesz, vagy határoz afelett, hogy milyen rendszabályokat kell a nemzetközi béke és biztonság fenntartása vagy helyreállitása érdekében a 41. és 42. Cikkek alapján foganatosítani”. A 39. cikk lényegében véve a 41. cikk és a 42. cikk alkalmazásának előfeltételeként funkcionál, mely szerint a BT egyrészt megállapíthatja a fentebb felsorolt három esetkör fennállását, másrészt rendelkezhet arról, hogy milyen intézkedéseket kell a béke és biztonság helyreállítása érdekében alkalmazni. Ezen intézkedések az arányosság elvére tekintettel klasszikusan kétfélék lehetnek: nem fegyveres és fegyveres kényszerintézkedések.

25 Utóbbi megítélése a nemzetközi jogtudományban szintén nem egységes. Lásd: Dickinson, 2003, 302-307. 0.; Nikolova és Ventura, 2013, 616. o.; Al-Rashidi, 2012, 8. o.; Aptel, 2007, 1108-1109. o.; Wetzel és Mitri, 2008, 87. o.; Fassbender, 2007, 1094-1095. o.

26 A jelenségről részletesebben lásd: Raisz, 2017, 449-450. o.; Kardos, 2006, 238-241. o.

27 Simma et al., 2012, 1275. o.; Dipalo, 2018, 67-68. o. 
Mint ahogyan azt az ICTY fellebbviteli tanácsa a Tadić-ügyben ${ }^{28}$ megerősítette, anyagi oldalról tekintve a 39. cikk egyfajta felhatalmazást, széles körủ diszkrecionális jogkört ruház a BT-re a béke veszélyeztetése, megsértése és a támadó cselekmények megállapítása tekintetében csakúgy, mint az esetlegesen meghozandó kényszerintézkedések esetén. A San Franciscó-i diplomáciai konferencián e cikk tekintetében is az Alapokmány politikai karaktere, a tág mérlegelési mozgástér kerekedett felül a jogi megközelítéshez, vagyis a rendelkezés előfeltételeinek pontos meghatározásához képest azon általános tendencia kíséretében, hogy a Biztonsági Tanácsot sokkal inkább eljárásjogi, semmint anyagi jogi korlátok kötik. Az Alapokmány tehát abszolút a BT-re bízza, hogy egy adott helyzetben miként cselekszik, és hogy egyáltalán cselekszik-e: cselekvési kötelezettsége akkor sem áll fenn, ha a béke veszélyeztetését, megsértését vagy akár agresszió cselekményének elkövetését állapítja meg. Ezzel összefüggésben a Biztonsági Tanácsot számos alkalommal érte erőteljes kritika passzivitása, különösen a védelmi felelősség figyelmen kívül hagyása miatt. A BT mozgástere ugyanakkor az anyagi jogi korlátoktól nem teljes mértékben „mentes”, minthogy cselekvési szabadsága a béke veszélyeztetésének, a béke megszegésének, illetve a támadó cselekmények elkövetésének eseteire terjed ki. ${ }^{29} \mathrm{~A}$ „béke veszélyeztetése”, a „béke megszegése és a „támadó cselekmények” fogalmát az Alapokmány nem határozza meg, azok kontúrjai a BT fennállásának 75 éve alatt a gyakorlat tükrében rajzolódtak ki. A „béke veszélyeztetését” illetően a tömegpusztító fegyverek proliferációja, a terrorizmus, a belső fegyveres konfliktusok és a kalózkodás egyértelmúen a klasszikus biztonsági kockázatok ernyojje alá tartoznak, továbbá a polgári lakosság, az emberi jogok és a demokratikus alapelvek védelme az emberiség biztonsága érdekében szintén érvényes jogalapot szolgáltathatnak. ${ }^{30} \mathrm{~A}$ „béke megszegésének” körülhatárolása az előbbitől némileg nehezebb, mert ezt a kifejezést a BT a gyakorlatban kevesebbet használta. Annyit azonban biztosan le lehet szögezni, hogy a legalább két állam közötti nemzetközi fegyveres konfliktusok tipikusan a béke megszegését eredményező esetkörök közé tartoznak. Idesorolhatjuk például az Argentína és az Egyesült Királyság között vívott Falkland-szigeteki háborút 1982-ből, ${ }^{31}$ vagy például az Irak és Kuvait közötti öbölháborút (1990-1991) is. ${ }^{32} \mathrm{~A}$,béke megszegése" effektíve független, államként el nem ismert, de facto rezsim által vagy ellen is megvalósulhat - állapította meg a Biztonsági Tanács 1950-ben, miután észak-

28 Decision on Defence Motion for Interlocutory Appeal on Jurisdiction, The Prosecutor v. Duško Tadić (IT-94-1AR72), Appeals Chamber, 2 October 1995, \$28 (a hivatkozásokban a továbbiakban: Tadić-ügy másodfokú határozat).

29 Tadić-ügy másodfokú határozat 28. \$.

30 Simma et al., 2012, 1275. o.

31 UN Doc. S/RES/502 (3 April 1982).

32 UN Doc. S/RES/660 (2 August 1990). 
koreai csapatok állítólagos határincidensek megtorlásaként megtámadták Dél-Koreát. ${ }^{33}$ A „támadó cselekmény”, illetőleg „agresszió cselekménye” a „béke megszegésénél” szúkebb fogalmi kört fednek le, melyekkel részletesebben az egyik késóbbi, A Nemzetközi Büntetőbíróság előtti eljárás megindítása a Római Statútum 15bis és 15ter cikkei alapján címú fejezet foglalkozik.

A nemzetközi büntető igazságszolgáltatás normatív gyökereinek feltárásához másodikként az ENSZ Alapokmány 41. cikkét kell közelebbről megvizsgálni, mely a Biztonsági Tanács által foganatosítható nem fegyveres kényszerintézkedésekről rendelkezik: „A Biztonsági Tanács határozza meg, hogy milyen fegyveres erők felhasználásával nem járó rendszabályokat kiván foganatositani abból a célból, hogy határozatainak érvényt szerezzen, és felhívhatja az Egyesült Nemzetek tagjait arra, hogy ilyen rendszabályokat alkalmazzanak. Ilyeneknek tekintendôk a gazdasági kapcsolatok, a vasúti, tengeri, légi, postai, távírói, rádió és egyéb forgalom teljes vagy részleges felfüggesztése, valamint a diplomáciai kapcsolatok megszakitása." Noha a 41. cikk a második világháború utáni, modern nemzetközi jog keretében létrejött kollektív biztonság rendszerének sarokpontja, a BT több mint két évtizeden át nem alkalmazta. Később, a hidegháború során is mindössze kétszer hivatkozott rá: elsőként 1966-ban hívta életre, amikor kereskedelmi embargót rendelt el Dél-Rhodéziával ${ }^{34}$ szemben, másodszor pedig 1977-ben, amikor Dél-Afrikát ${ }^{35}$ fegyverembargóval sújtotta. A '90-es évektől azonban az Alapokmány 41. cikke a békefenntartás bevett eszközévé nőtte ki magát, s a BT, felismerve az általános rendszabályok nemkívánt humanitárius „mellékhatásait”, előtérbe helyezte a célzott szankciókat (targeted sanctions), amelyek csak meghatározott árukat, személyeket vagy szervezeteket korlátoznak, ún. szankciós listára tétel (például vagyonbefagyasztás vagy beutazási tilalom) formájában. ${ }^{36} \mathrm{~A} 41$. cikk szignifikáns jellemzője, hogy a benne található felsorolás példálózó jellegú, melyről az ICTY fellebbviteli tanácsa - szintén a Tadić-ügyben - elvi éllel kimondta, hogy a rendelkezésben található intézkedések listája nem kimerítő jellegú, és e lista - az Alapokmány 29. cikkével ${ }^{37}$ összhangban - a nemzetközi büntető törvényszékek felállítását is magában foglalja. ${ }^{38}$

33 UN Doc. S/RES/82 (25 June1950).

34 UN Doc. S/RES/221 (9 April 1966).

35 UN Doc. S/RES/418 (4 November 1977).

36 Simma et al., 2012, 1309. o.

37 ENSZ Alapokmány 29. cikk: „A Biztonsági Tanács olyan kisegitő szerveket létesíthet, amelyeket feladatainak elvégzésére szükségesnek tart".

38 Tadić-ügy másodfokú határozat 34-35. \$\$. 


\subsection{A Biztonsági Tanács és a Nemzetközi Büntetőbíróság kapcsolata a Nemzetközi Jogi Bizottság 1994. évi statútumtervezetében}

A jelenlegi Nemzetközi Büntetőbíróság koncepciója ${ }^{39}$ - gyakorlatilag az ad hoc törvényszékek felállításával egyidejủleg - elsőként 1994-ben látott napvilágot az ENSZ égisze alatt, amikor a Nemzetközi Jogi Bizottság bemutatta a jövőbeli büntetôbírói fórumról szóló jelentését ${ }^{40}$ az univerzális nemzetközi szervezet Közgyúlésének. Az ICTY és az ICTR koncepciója által megihletve, az akkori tervezet szerint az „állandó Nemzetközi Büntetőbíróság” jobban függött volna a Biztonsági Tanácstól, lényegében véve annak végrehajtó szerveként funkcionált volna. ${ }^{41}$ Ez esetben csak a BT és a bíróság statútumában részes államok dönthettek volna arról, hogy mely helyzetek kerüljenek a bírói fórum elé, és a bíróság Főügyészi Hivatala önálló eljárásindító hatáskörrel egyáltalán nem rendelkezett volna. ${ }^{42}$

A '94-es tervezet az emberiesség elleni és a háborús bủncselekmények tekintetében úgy rendelkezett, hogy ha a $\mathrm{BT}$ egy helyzet előterjesztéséhez nem járul hozzá - az állam általi ad hoc, önkéntes alávetés esetét is beleértve -, akkor a bíróság csak akkor járhatott volna el, ha mind a gyanúsítottat őrizetben tartó állam, mind az az állam, amelynek területén a vádbéli bủncselekmény(eke)t elkövették, hozzájárult volna az eljárás megindításához. Ez volt az ún. „opt-in” rendelkezés: ha részes állam területén vagy részes állam állampolgára követte volna el az adott büncselekményt - a népirtást ide nem értve -, akkor az érintett államok esetről esetre dönthették volna el, hogy az ICC joghatóságához hozzájárulnak-e vagy sem.

A BT-t illetően a '94-es statútumtervezetnek további eltérése volt a végül hatályba lépett Római Statútumhoz képest, hogy a 23. cikk (3) bekezdése - ami végül átszövegezve a statútum 16. cikke alatt kapott helyet - úgy rendelkezett, hogy „a jelen Statútum szerint nem indítható nyomozás olyan helyzetben, melyet az Egyesült Nemzetek Alapokmánya VII. fejezetének értelmében a Biztonsági Tanács tárgyal a béke veszélyeztetése, megsértése vagy agresszió elkö-

39 UN Doc. A/CN.4/458 and Add.1-8 Observations of Governments on the report of the Working Group on a draft statute for an international criminal court. Extract from the Yearbook of the International Law Commission: 1994, vol. II (1). Topic: Draft code of crimes against the peace and security of mankind (Part II), including the draft statute for an international criminal court, elérhető: https://legal.un.org/ilc/documentation/english/a_cn4_458.pdf [Letöltve: 2017. 06. 16.].

$40 \mathrm{~A} / 49 / 10$ Report of the International Law Commission on the work of its forty-sixth session, 2 May-22 July 1994, Official Records of the General Assembly, Forty-ninth session, Supplement No. 10. Extract from the Yearbook of the International Law Commission: 1994 vol. II (2). Topic: Multiple topics, elérhető: https://legal. un.org/ilc/documentation/english/reports/a_49_10.pdf [Letöltve: 2019. 12. 10.] (a hivatkozásokban a továbbiakban: a Nemzetközi Jogi Bizottság 1994. évi statútumtervezete).

41 E verzió megvalósulása esetén a BT állandó tagjai - szükség esetén vétójoguk felhasználásával - ellenőrzést gyakorolhattak volna az ICC elé kerülő helyzetek felett.

42 Scheffer, 1999, 13. o. 
vetése miatt, hacsak a Biztonsági Tanács másképp nem határoz". ${ }^{43}$ Tehát e rendelkezés a bíróság előtti eljárás megindításának a lehetőségét kizárta volna, amennyiben az ENSZ Alapokmány VII. fejezete alapján a kérdés a BT napirendjén szerepel, hacsak a BT az eljárás megindításához nem járult hozzá. Így a Biztonsági Tanácsnak lehetősége lett volna az eljárást meggátolni úgy, hogy a szóban forgó kérdést az Alapokmány VII. fejezete szerint napirendjére túzi. ${ }^{44}$

A római diplomáciai konferencián ${ }^{45}$ a Nemzetközi Büntetőbíróság joghatóságának kérdése is heves viták kereszttüzébe került az ún. eljárásindító mechanizmusok miatt. Mint ahogyan arra az imént már történt utalás, az ILC '94-es tervezete ezekből eredetileg csak kettőt vázolt fel: egyrészt a Biztonsági Tanács utalhatott volna ügyeket a létrehozni kívánt bíróság elé, másrészt a részes felek élhettek volna e jogosultsággal a bíróság tárgyi joghatóságába tartozó bûncselekmények elkövetésének alapos gyanúja esetén. A tervezet továbbá felvázolt egy olyan államközi mechanizmust, mely példaként az Emberi Jogok Európai Bíróságánál, valamint a Nemzetközi Bíróságnál bevett eljárási modelleket preferálta volna, ahol az eljárás megindításával hátrányosan érintett (bepanaszolt vagy alperes állam) beleegyezése szükséges az eljárás megindításához. ${ }^{46}$

Ami az agresszió bủncselekményét illeti, az ILC '94-es statútumtervezete alapján az ICC joghatóságot gyakorolhatott volna a béke elleni búntett felett úgy, hogy annak elkövetését elsőként a BT-nek kellett volna megállapítania. E rendelkezést végül a római diplomáciai konferencián nem, csak a Római Statútum első felülvizsgálati konferenciáján fogadták el, és a hatályba lépett szövegváltozatban e rendelkezés - nehezen meghozott kompromisszumok útján - némiképpen árnyalódott. 1995-ben ugyanis a KGY Hatodik Főbizottsága jelezte, hogy több szempontból aggályosnak véli az agresszió tényleges beemelését a Római Statútumba ${ }^{47}$ - mely felett a bíróság végül csak 2018. július 17-tôl gyakorol tényleges joghatóságot -, így az 2002. július 1-jén a béke elleni búntett beemelése nélkül lépett hatályba.

43 UN Doc. A/49/10, \$23. (3).

44 Cryer et al., 2016, 146. 0.

45 Az Egyesült Nemzetek meghatalmazottjainak diplomáciai konferenciája egy nemzetközi büntetőbíróság létrehozásáról, Róma, 1998. június 15-július 17. A mintegy öthetes konferencián több mint 160 állam képviseltette magát. Számos ellentétes álláspont ütközött meg ekkor; a napirendi pontok között szerepeltek egészen részletekbe menő apró kérdések, mint például büntető eljárásjogi részletszabályok, ám politikailag erôteljesen motivált ügykörök is terítékre kerültek, úgymint a BT szerepe a majdani büntetőbíróság életében. A tárgyalások informális munkacsoportokban zajlottak, a döntéshozatal pedig lassú és nehézkes volt a kompromisszumok szükségessége miatt. Elérhető: https://www.coalitionfortheicc.org [Letöltve: 2016. 06. 13.].

46 Schabas, 2017, 144-149. o.

47 Schabas, 2004, 718. o. 
A Nemzetközi Jogi Bizottság tervezetét az ENSZ e célból felállított ad hoc bizottsága részletesen áttanulmányozta, majd 1995-ben egy átfogó jelentést ${ }^{48}$ tett közzé, amit a tervezet kíséretében megküldtek a KGY Előkészítő Bizottságának konszolidációs céllal, majd az Előkészítő Bizottság hat hivatalos értekezletet tartott 1996 és 1998 között. Végül a módosított szövegtervezet 1998 nyarán került a római diplomáciai konferencia asztalára:49 120 állam szavazott a Római Statútum elfogadása mellett, hét ellene, 21 pedig tartózkodott..$^{50}$ Így jött létre a nemzetközi közösség első állandó Nemzetközi Büntetőbírósága 1998. július 17-én.

\subsection{A Biztonsági Tanács és a Nemzetközi Büntetőbíróság kapcsolatára vonatkozó elméletek}

Ahogyan az az előzőek alapján láthatóvá vált, a Nemzetközi Büntetóbíróság és a Biztonsági Tanács kapcsolata már a bíróság felállításának szándékával összehívott római diplomáciai konferencián folyó tárgyalásoknak is az egyik legnagyobb jelentőséggel bíró kérdése volt, és a kortárs szakirodalom, valamint az ICC esetjoga arra enged következtetni, hogy ez ma sincs sokkal másképp.

A két intézmény sokrétú viszonyrendszerének dinamikáját alapjában véve két 'pillér' határozza meg: az elsô egy 'pozitív pillér', azaz a Biztonsági Tanács hatásköre arra, hogy az ENSZ Alapokmány VII. fejezete alapján helyzeteket utaljon ${ }^{51}$ a bíróság elé, a második pedig - az elsőt jellemző terminológia tükrében - egy 'negatív pillér', azaz a Biztonsági Tanács hatásköre arra, hogy az ENSZ Alapokmány VII. fejezete alapján a bíróság előtt folyamatban lévő nyomozást vagy büntetőeljárást felfüggessze. ${ }^{52} \mathrm{~A}$ két pillér közül az első a Római Statútum 13. cikk b) pontjában és 15ter cikk (1) bekezdésében, míg a második a 16. cikkében ölt testet, mely cikkek részletes elemzésére és a közvetlenül ezen rendelkezésekhez kapcsolódó gyakorlati problémák bemutatására a monográfia soron következő

48 UN Doc. A/50/22 (1995), Report of the Ad Hoc Committee on the Establishment of an International Criminal Court, UN GAOR, 50th Session., Suppl. No. 22 (6 September 1995).

49 Sadat, 2003, 567-568. o.

50 A szavazásról hivatalos jegyzőkönyv nem áll rendelkezésre, így csak valószínúsíteni lehet, hogy ez a hét állam India, Irak, Izrael, Katar, Kína, Jemen és az USA voltak. Lásd: Sadat, 2003, 570. o.

51 A Római Statútum hiteles, angol nyelvú szövegében a „referral” kifejezés szerepel, amely szó szerint „bíróság elé utalásként" fordítható, ugyanakkor e választás azért lehet kevésbé szerencsés, mert az "utalás” jogi szakkifejezésként a nemzetközi magánjog sajátja, amikor is a kapcsoló szabály utal a felhívott jogrendszer kollíziós normáira. Másik fordítási alternatívaként a „bíróság elé terjesztés” kínálkozik, amely esetlegesen az „előterjesztés” kifejezéssel mosódhat össze, melynek szintén messzire mutató következményei vannak mind az alkotmány-, mind a közigazgatási jogban. Jelen kötetben a „referral” mindkét fordítását használom azzal, hogy a helyes magyar jogi szakkifejezés tekintetében a hazai szakirodalom sem egységes. Például lásd: Lattmann, 2009, 9-23. 0.; Varga, 2006, 95-98. o.

52 Verduzco, 2015, 30. o. 
fejezetei tesznek kísérletet. Ugyanakkor elöljáróban érdemes lehet azokra az elméletekre is pillantást vetni, amelyek e két intézmény kapcsolatának jellemzésére szolgálnak a kortárs szakirodalomban. Ezek alapján az ICC és a BT kapcsolata elméleti síkon többféleképpen közelíthető meg aszerint, hogy a bíróság funkciói közül valaki éppen melyiket helyezi elötérbe. Deborah Ruiz Verduzco álláspontja értelmében praktikusan háromféle irányból szemlélhetjük e két intézmény viszonyát, ezek pedig (i) a Biztonsági Tanácshoz füződő funkcionalitás; (ii) a Római Statútum központú funkcionalitás; valamint (iii) az intézményi autonómia. Már e ponton lényeges megjegyezni, hogy az első két teória sem a BT, sem az ICC nemzetközi jogrendben betöltött funkciójából kiindulva nem tartható, és hogy a Nemzetközi Büntetőbíróság múködésének legitim alapját kizárólag az intézményi autonómia képezheti.

\subsubsection{A Biztonsági Tanácshoz füződó funkcionalitás,} avagy a Nemzetközi Büntetôbiróság mint a nemzetközi béke és biztonság eszköze?

Aligha vitatható, hogy az ICC egy olyan intézmény, amely közvetetten a nemzetközi békét és biztonságot hivatott erősíteni, mint ahogyan arra a Római Statútum Preambuluma is utalást tesz: „Felismerve azt, hogy ezek a súlyos büntettek veszélyeztetik a világ békéjét, biztonságát és jólétét [...]”. Továbbá a 13. cikk b) pontjának és a 16. cikknek ${ }^{53}$ a statútumba foglalása szintén ezen elméletet erôsíti, mely rendelkezések aktiválása a gyakorlatban az ENSZ Alapokmány VII. fejezete alapján hozott határozatot kíván meg a Biztonsági Tanácstól. ${ }^{54}$ Emellett az is helytálló megállapításnak túnik, hogy a bíróság BT-hez fưződő kapcsolatának célja végső soron a nemzetközi béke és biztonság fenntartásában teljesedik ki, minthogy a BT ennek első számú letéteményese, az ENSZ Alapokmány VII. fejezetében szereplő hatáskörök címzettje.

A Biztonsági Tanács az ENSZ egyik főszerve, melyre a tagok „a nemzetközi béke és biztonság fenntartásáért a fó felelösséget" ruházták [24. cikk (1) bekezdés], az ENSZ Alapokmány VII. fejezet 39. cikke pedig kimondja, hogy a BT „határoz afelett, hogy milyen rendszabályokat kell a nemzetközi béke és biztonság fenntartása vagy helyreállitása érdekében foganatositani”. A Biztonsági Tanács konfliktusos helyzetek bíróság elé utalására vonatkozó hatáskörének előképe az ad hoc törvényszékek létrehozásával rajzolódott ki, melyeket a BT segédszerveiként ${ }^{55}$ állítottak fel. Az ICTY és az ICTR létrehozásának e merőben új módozata mögött indokként a késedelem kiiktatása és a hathatós együttmúködés előmozdítása sejlett fel, mindazonáltal

53 Részletes ismertetésüket és elemzésüket lásd később.

54 Ádány, 2014, 179. o.

$55 \mathrm{Az}$ egyes segédszervekről lásd bővebben: Sievers és Davis, 2014 [Online]. 
a törvényszékek egy állandó nemzetközi büntetôbíróság ideáját is segítettek testközelbe hozni. ${ }^{56}$

A teóriát, miszerint az ICC a Biztonsági Tanács eszközeként funkcionál, a kortárs joggyakorlat továbbá a BT retorikájával próbálja alátámasztani, miszerint a bíróság elé vitt helyzetek „veszélyt jelentenek a nemzetközi békére és biztonságra nézve”. ${ }^{57}$ A Nemzetközi Büntetőbíróságról szóló legelső nyilvános vitán a Biztonsági Tanácsban többek között arról értekeztek, hogy "fel kellene térképezni, hogy az ICC a preventív diplomácia eszközeként hogyan segithetnéa BT-t mandátuma betöltésében". ${ }^{8}$ Ugyanitt és ugyanekkor Oroszország delegáltja úgy utalt a Nemzetközi Büntetôbíróságra, hogy „a Biztonsági Tanácsnak igen komoly új eszköz áll rendelkezésére ahhoz, hogy a nemzetközi jog által büntetni rendelt különös súlyú büncselekményeket elkövetö személyeket felelösségre vonják". 59

E megközelítés első pillantásra bármennyire befogadhatónak tûnjön is, néhány extrém következtetést is maga után von. Például azt, hogy a nemzetközi büntető igazságszolgáltatás hitelessége gyengülne, ha azt a BT egyes politikai ágendák teljesítésére használná fel, vagy ha az ICC „közbenjárását” politikai rendszerváltás eléréséhez vennék igénybe. Továbbá az is megjegyzendő, hogy azért, hogy a bíróságot a Biztonsági Tanács szolgálatába állíthassák, komoly árat kell fizetni a BT döntéshozatalában részt vevő ENSZ-tagállamoknak, különösképpen a Római Statútum részes államainak (így az Egyesült Királyságnak és Franciaországnak, illetve a BT nem állandó tagjainak), mivel az Egyesült Államok, Kína és Oroszország ICC-hez való ellenséges hozzáállása miatt sok esetben engedményeket kell tenniük és kompromisszumokat kell kötniük a bíróság nemzetközi közösségben betöltött pozícióját esetlegesen tovább gyengítve. A Nemzetközi Büntetóbíróságot a Biztonsági Tanács eszközeként szemlélve könnyen a „22-es csapdájában” láthatjuk a bírói fórumot: ha az ICC nem foglalkozik a tömeges nemzetközi jogi jogsértésekkel, akkor úgy tekintenek rá, mint a nemzetközi közösség lényegtelen és erőtlen szereplőjére, amely impotens a súlyos humanitárius katasztrófák kezelésében. Azonban ha az ICC hatékonyan lép fel, és egy eljárás megindul, a kritikusok aggályokat hozhatnak fel azon „komoly politikaiésjogi következmények miatt, melyek néha a biróság közbenjárását kísérik". ${ }^{60}$

56 Verduzco, 2015, 32. o.

57 Security Council Presidential Statement 2012/1 (2012), UN Doc. S/PRST/2012/1 (19 January 2012).

58 Concept Note 2012 Open Debate on Peace and Justice, elérhető: https://www.peacewomen.org/security-coun$\mathrm{cil} / \mathrm{security-council-open-debate-peace-and-justice-role-icc-october-2012} \mathrm{[Letöltve:} \mathrm{2020.} \mathrm{01.} \mathrm{24.].}$

59 Statement of Ambassador Churkin, 2012 Open Debate on Peace and Justice UNSC 6849th meeting, 19. Az orosz nagykövet reményekkel teli kezdeti megnyilvánulása ellenére Oroszország és az ICC jelenlegi kapcsolata korántsem nevezhető gyümölcsözőnek, ami a nagyhatalom BT-beli státusza miatt a bíróság működésére is kihatással van. Oroszország aláírta ugyan a Római Statútumot, ám 2016-ban az aláírást visszavonta egy nappal azután, hogy a bíróság egyik jelentésében Oroszország Krím-félszigeten való előrenyomulását annexiónak nyilvánította. Lásd: Gramer, 2016 [Online]; Esakov, 2017, 371-392. o.

60 Statement of Ambassador Churkin, 2012, 19. o. 
Összességében ugyanakkor megállapítható, hogy tarthatatlan az a nézet, mely szerint a Nemzetközi Büntetőbíróság a Biztonsági Tanács eszköze. Egyrészt azért, mert az ICC a nemzetközi jog önálló és objektív jogalanya, nem pedig a BT segédszerve. Másrészt azért, mert az ICC szuverén államok nemzetközi szerződéssel hozták létre, nem pedig a BT egyik határozata állította fel. Harmadrészt pedig e helyütt is hangsúlyozni kell, hogy míg a Biztonsági Tanács politikai, a Nemzetközi Büntetőbíróság igazságszolgáltatási szerv, így előbbi nem gyakorolhat érdemi befolyást a konkrét büntetőeljárásokra.

\subsubsection{A Római Statútum központú funkcionalitás?}

Létezik egy olyan elmélet is az ICC és a BT kapcsolatának magyarázatára, melynek középpontjában az a nézet áll, hogy a Biztonsági Tanács a bíróság szerződéses rezsimjének végrehajtó szerve, azaz az ICC rendszerének végrehajtó ága.

Érdekességként megemlíthető, hogy ez az elgondolás már I. Sándor orosz cár 1818. évi tervezetében tetten érhető, amikor is az uralkodó elsőként tett javaslatot egy olyan nemzetközi büntetőbíróság felállítására, amely nemzetek feletti intézményként büntető joghatóságot gyakorolt volna a rabszolgakereskedelem elkövetôi felett. A javaslatban kifejezetten elismerték, hogy egy járulékos végrehajtó szerv felállítása szükséges a büntetőbírói fórum határozatainak kikényszerítéséhez. E szerv a tervezet szerint a haditengerészet szervezetrendszerébe ékelődött volna be, a rabszolgakereskedelemben érintett vízi jármúvek átkutatása és feltartóztatása céljából. I. Sándor elképzelése alapján egy irányító tanácsot is létrehoztak volna a haditengerészet mûveleteinek összehangolására, a bíróság határozatainak végrehajtására, illetőleg a szervezet tagállamai felé intézett jelentéstételre. ${ }^{61}$

E teória alapjai Hans Kelsen 1944-ben publikált, Jog teremtette béke (Friede durch Recht) címú tanulmányában is megjelentek, melyben az osztrák származású jogtudós a Nemzetek Szövetsége bukására reflektált. Kelsen beépítette a bírói aktusok végrehajtásának ötletét az általa Békefenntartó Szervezetnek nevezett modellbe, mely szerint az igazságszolgáltatás - beleértve az egyének feletti büntető joghatóság gyakorlását is - a szervezet egyik központi feladata. Kelsen felismerte, hogy a nemzetközi büntetőbíráskodásnak szüksége volna végrehajtó ágra, így egy olyan állandó tanács felállítását szorgalmazta, mely a bírósági határozatok kikényszerítését látja el, és amelyben az Egyesült Államok, az Egyesült Királyság, Kína és a Szovjetunió állandó tagként van jelen. ${ }^{62}$

A Római Statútum végleges verziójában fellelhetők e harmadik elmélet „foszlányai” például akkor, amikor a Preambulum úgy fogalmaz, hogy „a nemzetközi közösség egészét érintő

61 Verduzco, 2015, 34. o.

62 Fassbender, 2008, 126-147. o. 
legsúlyosabb büntettek nem maradhatnak büntetlenül”. ${ }^{63} \mathrm{Az}$ ICC joghatósága az államok büntető joghatóságából fakad, annak „eredője”: a Római Statútum aláírásával az államok elismerték az egyének korábban is fennálló nemzetközi jogi kötelezettségeit, és egyfajta joghatósági többletet adtak az állami szintû́ büntetőeljárásokhoz. Hasonló elméleti síkon mozog az ad hoc bíróságok joghatóságmodellje is: az ICTY és az ICTR tárgyi joghatósága olyan büncselekmények szankcionálására terjed ki, amelyek „a nemzetközi szokásjog részét képezik”, ${ }^{64}$ vagy amelyek felett a joghatóság gyakorlását az érintett államok idevonatkozó nemzetközi szerződések ratifikációjával elfogadták. (Ugyanis utóbbi előfeltétel figyelmen kívül hagyásával a Biztonsági Tanács ultra vires járt volna el. $)^{65}$

Az ultra vires hatáskörgyakorlás tilalmának elvét nemcsak az ad hoc törvényszékek, hanem a Nemzetközi Büntetőbíróság esetében is tiszteletben kell tartani. Az ENSZ Alapokmánya által keretbe foglalt jogalkotási hatáskörök szerint, a már korábban fennálló kötelezettségeken alapuló felelősségre vonást szem előtt tartva kell a Biztonsági Tanácsnak eljárni akkor, amikor egy konfliktusos helyzetet terjeszt az ICC elé. Ebből a szemszögből nézve az ICC nem tûnik a BT eszközének, mi több, a Biztonsági Tanács múködik közre a bíróság végrehajtó szerveként.

A BT végrehajtó szerepének víziója a Római Statútum elfogadását megelőző tárgyalásokon mindvégig jelen volt; az elfogadott statútumban ennek eredménye különösen a nem részes államoktól való segítségnyújtás kérésében és az együtt nem múködésre adható BT-válaszban mutatkozik meg. ${ }^{66}$

A tényleges gyakorlatban mindhárom modell felsejlik: az államok hajlamosak egyszer az egyik, máskor a másik elmélet erősségeit hangsúlyozni, mely eseti jellegú hivatkozásokhoz és ellentmondásokhoz vezet. Ennek oka részint a Biztonsági Tanács természetében keresendő. A BT elsődlegesen politikai szerv, amelynek határozatai gyakran retorikai fordulatokkal átszőttek és szimbolikus értékủek, ${ }^{67}$ intézményes keretei pedig a bíróságétól teljesen különböznek: az ICC feladata a tényeken alapuló, bírói nyelvezetben formába öntött döntéshozatal. E különbségek pedig feszültséget keltenek a két szerv kapcsolatában, különösen az ICC joghatóságának aktiválása, az eljárások finanszírozása, a bíróság előtti eljárások felfüggesztése, az államokkal való együttmúködés és a bírósági határozatok végrehajtása tekintetében.

63 Római Statútum Preambulum 5. bekezdés: „Megerősitve azt, hogy a nemzetközi közösség egészét érintő legsúlyosabb büntettek nem maradhatnak büntetlenül, és a hatékony felelösségre vonást nemzeti intézkedésekkel és a nemzetközi együttmüködés erősitése révén kell biztosítani."

64 Sadat, 2006. 187. o.

65 Milanović, 2011, 27. o.

66 Verduzco, 2015, 35. o.

67 Johnstone, 2003, 439. o. 
Mindazonáltal e nézetet sem lehet dogmatikai értelemben megalapozottnak tekinteni részint az előző pont végén megfogalmazottak, részint pedig a két intézmény eltérő eszköztára, jellege és rendeltetése miatt.

\subsubsection{Az intézményi autonómia}

Mind a Biztonsági Tanácshoz füződő, mind a Római Statútum központú funkcionalitás elmélete ellentétben áll mind a bírói függetlenség, mind a bírói hatalmi ág és a politika szükségszerû szétválasztásának követelményével, ellenben az intézményi autonómia melletti érvek e tekintetben tradicionálisnak és megalapozottnak mondhatók.

A Nemzetközi Jogi Bizottság korai, 1991-ben napvilágot látott, egy állandó nemzetközi büntetőbíróság víziójáról szóló jelentése szerint a BT mérsékeltebb szerephez jutott volna a mostanihoz képest, mivel az ILC ekkor még összeegyeztethetetlennek látta a nemzetközi béke és biztonság fenntartását egy nemzetközi büntetőbírói fórum közremúködésével. ${ }^{68}$ A két intézmény szétválasztása melletti legfőbb érv az volt, hogy könnyebb a büntetôbíróság hitelességét úgy megőrizni, ha elejét veszik annak, hogy a politikai szerv érdemi ügyek bíróság elé kerülését esetlegesen meggátolhatja. ${ }^{69} \mathrm{E}$ nézet 1993-ig, az ICTY megszületéséig tartotta magát, majd az ILC '94-es tervezetébe már a jelenleg hatályos szöveg került.70

A Római Statútum elfogadását megelőző tárgyalások végének közeledtével azonban a megosztottság volt jellemző a BT hatáskörei és a bírói függetlenség egyensúlyát illetően. Ebben az időszakban újra felerősödtek azok a hangok, amelyek az intézményi autonómia szükségességét hallatták. Az ICTY egykori föügyésze, Louise Arbour úgy nyilatkozott a BT-hez füződő kapcsolatról, hogy az „valójában inkább kiemelte az ICC jelentöségét, semmint felerősitette volna állitólagos elrettentőhatását”, és ebből az okból adódóan fogalmazta meg az igényt, hogy „megfontoltnak kell lenni az igazságszolgáltatás és a fegyveres konfliktusokra adható válaszok közelitését illetôen".71

A bíróság végleges jogállását tekintve ez a megközelítés kerekedett felül a tekintetben, hogy az ICC a nemzetközi jog önálló jogalanyává vált, nem tagja az ENSZ-családnak, és anyagi tekintetben független az univerzális nemzetközi szervezettől.

68 Ninth Report on the Draft Code of Crimes against the Peace and Security of Mankind, by Mr Doudou Thiam, Special Rapporteur, UN Doc. A/CN.4/435 (8 February 1991); UN Doc. A/CN.4/435.Add.1 (15 March 1991), Section C, Criminal Proceedings, $\$ \$ 56,58$, in: ILC Yearbook $43^{\text {rd }}$ Session UN Doc. A/CN.4/SER.A/1991/Add.I (Part 1) (1991). A Biztonsági Tanács szerepének jelentősége csupán az agresszió kapcsán merült fel, tekintve, hogy e bủntett vonja leginkább maga után a nemzetközi béke jelentős sérelmét.

69 Eight Report on the Draft Code of Crimes against the Peace and Security of Mankind, Special Rapporteur, UN Doc. A/CN.4/430 (6 April 1990); valamint UN Doc. A/CN.4/430 Add.1, in: ILC Yearbook $42^{\text {nd }}$ Session UN Doc. A/CN.4/SER.A/1990/Add.1 (Part 2) (1990).

70 Schabas, 2017, 149. o.

71 Arbour, 2013 [Online]. 

II.

RÉSZ

\section{A Nemzetközi Büntetőbíróság és a Biztonsági Tanács kapcsolatánalk normatív keretei a Római Statútumban}




\section{A Nemzetközi Büntetőbíróság előtti eljárás megindítása a Római Statútum 13. cikk b) pontja alapján}

\subsection{A Biztonsági Tanács mint eljárást indító mechanizmus}

A nemzetközi közösségben már a második világháború vége óta érlelődött az igény² egy állandó nemzetközi büntetőbírói fórum felállítására, amely csak mintegy ötven évvel később, a Nemzetközi Büntetőbíróság felállításával ölthetett testet. Az ICC-t létrehozó Római Statútum ugyanakkor csupán úgy kerülhetett elfogadásra, hogy a szerződés normái széles körben elismerésnek örvendő kompromisszumot tükröznek, amelyek közül az egyik legfontosabb az ICC előtti büntetőeljárások megindításának alanyai köre és a bíróság joghatóság-gyakorlásának komplex kérdése volt. Utóbbiaknak köszönhetően pedig a Nemzetközi Büntetőbíróság joghatóságmodellje merőben eltér a nemzetközi jogban addig „bevettnek” mondható vagy a belső jogrendszerekben alkalmazott klasszikus megoldásoktól.

A tekintetben a Nemzetközi Büntetőbíróság sem képez kivételt a nemzetközi bíróságok között, hogy az ICC joghatósága még a Római Statútumban részes államok esetében sem automatikus, tekintve, hogy a bíróság előtti ügyeknek a statútumban támasztott többletkövetelményeknek is maradéktalanul meg kell felelniük. (Ebben tehát valamennyi nemzetközi bíróság hasonló, ellenben a nemzeti bírói fórumokhoz viszonyítva utóbbi markáns eltérésként jelentkezik.) Másrészt a bíróság mellett múködő Főügyészi Hivatal esetében nem érvényesül a hivatalból történő vádemelés elve, így attól még, hogy fennáll az ICC időbeli és tárgyi joghatóságába tartozó bủncselekmények alapos gyanúja, a fö̈ugyész vádemelési monopóliuma teljes mértékben diszkrecionális jellegû̉. ${ }^{33}$ Továbbá kiemelést érdemel a ne bis in idem elvének sajátos, „vertikális” érvényesülése: az ügyben eljáró tárgyalás-előkészítő tanács a joghatóság hivatalból történő vizsgálatakor a nemzeti

72 Ez az igény már az 1948. évi Genocídium-egyezmény VI. cikkének szövegében is testet öltött, miszerint: „A népirtással, vagy a III. Cikkben felsorolt egyéb cselekmények bármelyikének elkövetésével vádolt személyek felett azon állam illetékes bírósága itélkezik, melynek területén a cselekményt elkövették, vagy a Nemzetközi Büntető Bíróság azon Szerződő Felek viszonylatában, amelyek annak joghatóságát magukra nézve elismerték", ám realitássá csak évtizedekkel később vált. Mindenesetre rendkívül beszédes a magyar fordítás, mely szó szerint „Nemzetközi Büntető Bíróság”-ról rendelkezik. Lásd: 1955. évi 16. törvényerejű rendelet a népirtás bủntettének megelőzése és megbüntetése tárgyában 1948. évi december 9. napján kelt nemzetközi egyezmény kihirdetéséről.

73 Erre mutatott rá Louise Arbour, az ICTY korábbi ügyésze is 1997-ben, a Nemzetközi Büntetőbíróság egyik előkészítő bizottságának ülésén. Arbour hangsúlyozta, hogy a nemzeti és a nemzetközi büntetőeljárások egyik karakterisztikus különbsége, hogy míg a belső jogban, ha az eljárás megindításának csak a legtriviálisabb feltételei állnak fenn, akkor is hivatali kötelezettsége az ügyészségnek a büntetőeljárás lefolytatása. Ezzel szemben a nemzetközi gyakorlatban - a komplementaritás elvével összhangban - az ügyészség diszkrecionális jogköre érvényesül. Lásd: Arbour, 2014, 195. o. 
- egyébként joghatósággal rendelkező, de eljárni nem hajlandó vagy nem képes - bíróság előtt lezajlott vagy éppen folyamatban lévő eljárást veszi figyelembe, annak érdekében, hogy megállapítsa, hogy a vád tárgyát ugyanannak a terheltnek ugyanolyan tartalmú cselekménye képezi-e.

A Nemzetközi Büntetőíróság előtt a Római Statútum 13. cikke ${ }^{74}$ szerint háromféleképpen indulhat meg az eljárás (trigger mechanisms): (i) a Római Statútumban részes államok indítványával; (ii) a Biztonsági Tanács eljáráskezdeményezésével az ENSZ Alapokmány VII. fejezete alapján; valamint akkor, ha (iii) a föügyész saját hatáskörében eljárva, ún. proprio motu kezdeményezi egy helyzetben vagy ügyben az előzetes vizsgálat lefolytatását. E ponton kihangsúlyozandó, hogy a részes államok és a BT - utóbbi lévén politikai és nem igazságszolgáltatási szerv - csupán absztrakt szituációkat utalhatnak az ICC elé, a konkrét ügyek meghatározása és gyanúsítottak megnevezése, valamint a vádemelés kizárólagos ügyészi hatáskört képez.

A Római Statútum 13. cikk b) pontja - mint a Nemzetközi Büntetőbíróság és a Biztonsági Tanács közötti „hídképző mechanizmus”s - rögzíti a BT eljárásindító hatáskörét. Ennek értelmében az ENSZ főszerve helyzeteket terjeszthet a Nemzetközi Büntetőbíróság Föügyészi Hivatala elé, ${ }^{76}$ melynek előfeltétele, hogy a BT az ENSZ Alapokmány 39. cikke szerint a nemzetközi béke és biztonság sérelmét vagy az agresszió cselekményének elkövetését határozat formájában megállapítsa. E határozatok az ENSZ Alapokmány 41. cikke alatt szabályozott nem fegyveres kényszerintézkedések közé sorolhatók, mely a jogszabályhely példálózó felsorolásából ${ }^{77}$ következik.

74 Római Statútum 13. cikk: „A Bíróság joghatóságát egy, az 5. cikkben meghatározott büntett tekintetében a jelen Statútum rendelkezései szerint akkor gyakorolhatja, ha:

a) a Részes Állam a 14. cikknek megfelelöen a föügyész elé utalja azt az esetet, amellyel kapcsolatban feltehetö, hogy egy vagy több ilyen büntettet elkövettek;

b) a Biztonsági Tanács az Egyesült Nemzetek Alapokmánya VII. fejezetének megfelelóen eljárva a föügyész elé utalja azt az esetet, amellyel kapcsolatban feltehetö, hogy egy vagy több ilyen büntettet elkövettek; vagy

c) a fö̈̈̈yész indított nyomozást ilyen büntett miatt a 15. cikkértelmében."

75 Rastan, 2015, 157. o.

76 E ponton szeretném felhívni a figyelmet a Római Statútum Országgyủlés honlapján található fordításának pontatlanságára. A fő szövegben szereplő idézett jogszabályhelyből látszik, hogy a T/383. számú törvényjavaslat e rendelkezése helytelenül „esetet” említ, amiből arra lehetne következtetni, hogy itt már konkrét ügyek előterjesztéséről van szó. Ezzel ellentétben a „situation” kifejezés a hiteles angol nyelvű verzióban arra utal, hogy a Biztonsági Tanács egy időben és térben lehatárolt, a nemzetközi békét és biztonságot veszélyeztető konfliktusos helyzetet utal az ICC elé, mely alapján a Föügyészi Hivatal jogosult vádat emelni az egyes elkövetôk ellen. Lásd: T/383. számú törvényjavaslat a Nemzetközi Büntetőbíróság Statútumának és a Statútum 8. cikkére vonatkozó kampalai módosításának kihirdetéséről. Elérhető: https://www.parlament.hu/ irom41/00383/00383.pdf [Letöltve: 2021. 04. 22.].

77 A BT nemzetközi büntető igazságszolgáltatáshoz való viszonya és az ENSZ Alapokmány 41. cikke kapcsán az ICTY fellebbviteli tanácsa rögzítette, hogy az ott szereplő nem fegyveres kényszerintézkedések felsorolása példálózó jellegú. Lásd: Tadić-ügy másodfokú határozat; Decision on Defence Motion on Jurisdiction, The Prosecutor v. Duško Tadić (IT-94-1-T), Trial Chamber, 10 August 1995; Kirs, 2018b, 14-15.; Kirs, 2018a, 57-77. 
A bíróság joghatóság-gyakorlásának előfeltételeiről a Római Statútum 12. cikke rendelkezik, melynek (2) bekezdése $\mathrm{e}^{78}$ értelmében az ICC a büntetőeljárás lefolytatására akkor válik jogosulttá, (i) ha valamely részes állam területén - ideértve az úszó és a repüló államterületet - követik el az 5. cikkben nevesített bưncselekmények (népirtás, emberiesség elleni bưncselekmények, háborús bûncselekmények, agresszió) valamelyikét, vagy (ii) ha az elkövető valamely részes állam állampolgára. A 12. cikk (2) bekezdése a contrario nem alapozza meg a joghatóság-gyakorlást akkor, ha a gyanúsítottat fogva tartó állam a részes fél, sem akkor, ha a bưncselekmény sértettjének állampolgársága szerinti állam a részes fél (ún. passzív személyi elv) a Római Statútumban.

(i) A 12. cikk (2) bekezdés a) pontja a területi hatály elvéből indul ki a joghatóság megállapításakor, ami kétséget kizáróan az állami szuverenitás egyik legfóbb attribútuma, ${ }^{79}$ melyet az államok vagy saját bíróságaik útján gyakorolnak, vagy nemzetközi szerződéssel delegálják azt, mint ahogyan az a Római Statútum 4 . cikk (2) bekezdésében ${ }^{80}$ kifejezésre kerül. Ami az úszó és repülő államterületeket illeti, az az állam minősül területi államnak, amelyik a vízi vagy a légi jármúvet lajstromába bejegyezte. E rendelkezés egyrészt az ENSZ 1982. évi Montego Bayben kelt tengerjogi egyezményének ${ }^{81}$ 91. cikk (1) bekezdését, másrészt az 1944. évi nemzetközi polgári repülésről szóló chicagói egyezmény ${ }^{82}$ 17. cikkét tükrözi. Az ICC-re delegált területi joghatóság gyakorlásának nem előfeltétele, hogy az állam az érintett terület felett effektív kontrollt gyakoroljon, ez utóbbira hipotetikus példaként az Észak-ciprusi Török Köztársaság esetét lehet felhozni. ${ }^{83}$

(ii) A 12. cikk (2) bekezdés b) pontja alatt szereplő személyi elven alapuló joghatóság a szuverén állam és az állampolgárok közötti jogi kapcsolat ${ }^{84}$ elismerésére épül, ${ }^{85}$ mely kapcso-

78 Római Statútum 12. cikk (2) bekezdés: „A 13. cikka) vagy c) pontjának megvalósulása esetén, a Bíróság joghatósággal rendelkezik, ha az alábbi államok közül legalább az egyik jelen Statútum Részes Állama, vagy pedig, ha az adott állam a (3) bekezdéssel összhangban alávetette magát a Bíróság joghatóságának:

a) Részes Állam területén követték el a kérdéses cselekményt, illetve lajstromba vett vízi vagy légi jármüvén;

b) Az elkövetô valamely Részes Állam állampolgárságát viseli."

79 Shaw, 2003, 579. o.

80 Római Statútum 4. cikk (2) bekezdés: „A Bíróság funkcióités jogosítványait a jelen Statútumban meghatározott módon gyakorolhatja bármely Részes Állam, továbbá külön megállapodás révén, bármely más Állam területén."

81 1982. évi Montego Bay-egyezmény 91. cikk (1) bekezdés: „Minden állam megállapítja azokat a feltételeket, amelyek alapján a nemzeti hovatartozását hajóknak megadja, területén a hajókat lajstromozza, valamint megadja a jogot a lobogója alatt történő hajózáshoz. A hajók azon állam nemzetiségével rendelkeznek, amely állam lobogója alatt joguk van hajózni. Az állam és a hajó között valóságos kapcsolatnak kell fennállnia" (United Nations Convention on the Law of the Sea, Montego Bay, 10 December 1982. 1833 UNTS 3).

82 1944. évi chicagói egyezmény 17. cikk: „A légi jármü ahhoz az Államhoz tartozik, amelynek lajstromába be vanjegyezve" (1971. évi 25. törvényerejû́ rendelet a nemzetközi polgári repülésről Chicagóban, az 1944. évi december hó 7. napján aláírt Egyezmény és az annak módosításáról szóló jegyzőkönyvek kihirdetéséről).

83 Schabas, 2017, 285. o.

84 Ganczer, 2011, 61. o.

85 Shaw, 2003, 584. o. 
latból az állampolgár passzív jogalanyisága is következik, azaz hogy az állam büntető joghatóságot gyakorolhat felette. A személyi elven gyakorolt joghatóságnak különösen a common law jogcsaládba tartozó államokban van régi hagyománya - részben ezzel is magyarázható, hogy ennek alkalmazása a területi elven gyakorolt joghatósággal szemben kevesebb bírálatot vont maga után. ${ }^{86}$

A Római Statútum 12. cikk (2) bekezdését a Biztonsági Tanács által kezdeményezett eljárások esetén nem kell figyelembe venni, melyből adódik, hogy a részes államok és a föügyész eljárásindításától eltérően a $\mathrm{BT}$ nem részes államok területén, illetve nem részes államok állampolgárai által elkövetett nemzetközi búntetteket - vagyis olyan helyzeteket, amikben fennáll ilyen büntettek elkövetésének alapos gyanúja - is az ICC elé terjeszthet. Az időbeli joghatóság kapcsán a Biztonsági Tanácsnak egyedül arra kell tekintettel lennie, hogy a statútum hatálybalépése (2002. július 1.) előtti események nem képezhetik az eljárás megindításának alapját, ám az érintett állam egyéni ratifikációjának időpontja értelemszerúen irreleváns.

Jóllehet a Római Statútumban sehol nem található ennek kizárólagosságára való utalás, az eddigi gyakorlat tükrében a BT indította eljárások csak a Római Statútumban nem részes államokat érintették. Ellentétben a részes államok által előterjesztett helyzetekkel és a föügyész proprio motu eljárásaival - melyek esetében a joghatóság-gyakorlásnak feltétele a Római Statútum ratifikációja, az ahhoz való csatlakozás vagy eseti alávetési nyilatkozat tétele az állam részéről -, a 13. cikk b) pont alapján hozott BT-határozatok ipso iure megalapozzák az ICC joghatóságát, amiből következik, hogy a Biztonsági Tanács ilyen határozatai a Római Statútumban nem részes államok esetén per se érvényes jogalapot szolgáltatnak a bíróság joghatóság-gyakorlásához, valamint hogy a BT eljáráskezdeményező hatásköre szélesebb, mint a Fő̈gyészi Hivatalé, vagy mint a részes államok erre vonatkozó jogosultsága.

Ugyanakkor az már megosztja a nemzetközi jogászokat, hogy a BT határozata joghatóságot teremt-e, vagy csupán az egyébként már létező „passzív” joghatóságot aktiválja. Az első

86 Shaw, 2003, 589. E tekintetben a Nemzetközi Büntetőbíróság vitathatatlanul legnagyobb kritikusa az Amerikai Egyesült Államok. Az ICC-t elítélő amerikai kormányzati közleményektől időről időre visszhangzik a sajtó, elég csak a legutóbbi republikánus adminisztráció tagjainak, Donald Trump elnök, Mike Pompeo külügyminiszter vagy John Bolton nemzetbiztonsági tanácsadó elmúlt két évben napvilágot látott nyilatkozataira gondolni. Az amerikai kormány 2019 tavaszán eljutott egészen odáig, hogy beutazási tilalmat helyezett kilátásba az ICC bíráival és föügyészével szemben, amennyiben a tárgyalás-előkészítő tanács engedélyezi a Fő̈ugyészi Hivatalnak, hogy nyomozást indítson az afganisztáni helyzetben. Az Egyesült Államok jogi „köntösbe” bújtatott érvei a bíróság harmadik államok feletti joghatóság-gyakorlását állítják célkeresztbe azzal, hogy ICC-ellenes attitűdjét áthatja az elmélet és a gyakorlat közötti dichotómia: míg formálisan - nehezen védhető - jogi érvekkel igyekszik álláspontját alátámasztani, a bíróság irányába érzett „ellenszenve” egyértelmúen politikailag motivált. Lásd: Galbraith, 2003, 683-702. o.; Roscini, 2006, 498. o.; Cline, 2008, 110. o.; Schabas, 2004, 702. o.; Akande, 2003, 635. o.; Mégret, 2001, 249-251. o. 
irányzat képviselői abból indulnak ki, hogy az ICC joghatósága alapvetően beleegyezésen alapul, ezért amikor a BT-határozatok olyan esetekben ruháznak joghatóságot a bíróságra, amikor a ratifikáció vagy az eseti alávetés hiányzik, akkor a nem részes államok tekintetében megsértenék a visszaható hatály tilalmát, hacsak nem maga a Biztonsági Tanács határozata az a jogi aktus, ami a joghatóságot megteremti. ${ }^{87}$

A másik nézet szerint a Római Statútum kodifikációjakor az államok univerzális joghatóságukat foglalták írásba, amely a statútum hatálybalépése óta valamennyi egyént nyomatékosan kötelez, és így az ICC univerzális joghatóságot gyakorol a népirtás, az emberiesség elleni és a háborús bûntettek, valamint az agresszió felett, melynek tényleges gyakorlására azonban csak egyéb feltételek együttes fennállása esetén van lehetősége (úgymint például a statútum ratifikációja vagy az eseti alávetési nyilatkozat, illetve a nemzetközi béke és biztonság veszélyeztetése esetén meghozott BT-határozat). ${ }^{88} \mathrm{~A}$ Római Statútum nyelvezete - így különösen A joghatóság gyakorlásának előfeltételei címet viselő 12. cikk - ez utóbbi álláspontot erősíti, továbbá a nullum crimen sine lege elve is. Ám még az ENSZ Alapokmány VII. fejezete alapján gyakorolt tekintélyes hatáskörök sem jogosítják fel a Biztonsági Tanácsot a Római Statútum teremtette keretrendszer „szétfeszítésére”, azaz a BT nem hatalmazhatja fel az ICC-t arra, hogy ultra vires - például időbeli vagy tárgyi joghatóságát túllépve - járjon el. ${ }^{89}$

E helyütt szintén érdemes megemlíteni, hogy a szakirodalom a Nemzetközi Büntetôbíróság BT-határozatokra vonatkozó bírósági felülvizsgálata mentén ugyancsak megosztott. Bár a Római Statútum 19. cikk ${ }^{\circ}$ (1) bekezdése kimondja, hogy a bíróság meggyőződik arról, hogy fennáll-e joghatósága az elé terjesztett ügyben - melyből logikusan következne annak vizsgálata, hogy a joghatóság „aktiválását” szolgáló mechanizmus jogszerú volt-e -, a gyakorlatban nehezen lenne elképzelhetô, hogy az ICC a nemzetközi béke és biztonság sérelmének megállapítását - mint a Biztonsági Tanács politikai döntését - felülvizsgálja, ami nem is fordult elö a gyakorlatban napjainkig.

A BT által indított eljárások további sajátossága, hogy a Római Statútum 18. cikkében ${ }^{91}$ szereplő, az előzetes döntés elfogadhatóságáról szóló szabályokat nem kell alkalmazni, mind-

87 Milanović, 2011, 34. o., 37-38. o.

88 Sadat és Carden, 2000, 409-410. 0., 412-413. o.

89 Cassese, Gaeta és Jones, 2002, 575., 578. o.

90 Részletes elemzését lásd később A komplementaritás és a Biztonsági Tanács által kezdeményezett eljárások címú fejezetben.

91 Római Statútum 18. cikk: „(1) Ha egy esetet a 13. cikk (a) bekezdése alapján a Bíróság elé terjesztettek, és a föügyész úgy döntött, hogy a nyomozás megindítása indokolt, vagy a fö́̈gyész kezdeményezi a nyomozás megindítását a 13. cikk (c) bekezdése és a 15. cikk szerint, a fö̈̈gyész értesíti az összes Részes Államot és azon Államokat, amelyek, a rendelkezésre álló adatokra figyelemmel, az adott büntettek fölött általában joghatósággal rendelkeznének. A fö̈̈gyész ezeket az Államokat titkosan értesitheti, és, amikor úgy véli, hogy bizonyos személyek védelme, bizonyítékok megsemmisitésének vagy bizo- 
azonáltal - mint ahogyan arról a monográfiában a későbbiek folyamán részletesen szó esik majd - az elfogadhatóság kérdéseiról szóló 17. cikket, ${ }^{92}$ valamint a bíróság joghatóságának és az ügy elfogadhatóságának megtámadásáról szóló 19. cikket ${ }^{93}$ viszont igen. Az 53. cikk (3) bekezdés a) pontjával94 összhangban pedig a BT is indítványozhatja a tárgyalás-előkészítő tanácsnál, hogy vizsgálja felül a fö̈̈gyész eljárás megindításának megtagadásáról hozott határozatát.

A 13. cikk b) pontjának nyelvtani értelmezése után három érdemi konklúzió tárható fel. Az első, hogy (i) a BT eljárásának materiális feltétele, hogy olyan helyzetet utaljon az ICC elé, „amellyel kapcsolatban feltehetö, hogy egy vagy több ilyen büntettet elkövettek”. A második, hogy (ii) a BT az ENSZ Alapokmány VII. fejezete alapján járjon el („az Egyesült Nemzetek Alapokmánya VII. fejezetének megfelelően eljárva"). A harmadik pedig, hogy (iii) még ha e fenti kritériumok maradéktalanul megvalósulnak, a bíróságnak akkor sem kötelező az eljárást megindítania,

nyos személyek szökésének megakadályozása miatt szükséges, korlátozhatja az Államok számára nyújtott információ terjedelmét.

(2) Azértesités átvételétól számittott egy hónapon belül az Állam értesittheti a Bíróságot, hogyállampolgárai, vagya joghatósága a lá tartozó más személyek ügyében megindítja, vagy megindította a nyomozást az 5. cikkben írt bármelyik büntetteknek minősithető azon büncselekmények miatt, amelyek összefüggésben állnak az Államoknak küldött értesitésben közölt információval. Ezen Állam kérésére a föügyész átengedheti az adott személyek elleni nyomozás lefolytatását az Államnak, kivéve, ha a tárgyalás-előkészitő tanács, a föügyész megkeresésére, a nyomozást engedélyezi.

(3) A fö̈ügész azon döntését, amellyel az Állam számára átengedi a nyomozás lefolytatását, az átengedés után hat hónappal vagy bármikor felülvizsgálhatja, ha a körülmények lényegesen megváltoztak az Államnak a megfeleló nyomozás lefolytatására való hajlandósága, vagy képessége tekintetében.

(4) Az érintett Állam vagy a föügyész a 82. cikk szerint fellebbezhet a fellebbviteli tanácshoz a tárgyalás-elókészítô tanács döntése ellen. A fellebbezés gyorsitott eljárásban is eldönthetó.

(5) Ha a föügyész a nyomozást a 2. bekezdés szerint átengedte, kérheti az érintett Államot, hogy rendszeresen értesitse a nyomozás és az azt követő büntetőeljárás lefolyásáról. A Részes Âllamok indokolatlan késedelem nélkül válaszolnak az ilyen kérelmekre.

(6) A föügyész, a tárgyalás-előkészitó tanács döntésének meghozataláig vagy bármikor, miután a jelen cikk értelmében átengedte a nyomozást, rendkivüli felhatalmazást kérhet a tárgyalás-elókészitôt tanácstól arra, hogy a bizonyitékok megóvása érdekében szükséges nyomozati cselekményeket megtegye, amennyiben egyedülállólehetöségáll fenn fontos bizonyiték megszerzésére, vagy jelentôs veszély áll fenn arra nézve, hogy a bizonyiték később már nem szerezhetó meg.

(7) Az Állam, amely a tárgyalás-előkészitő tanácsnak a jelen cikk értelmében hozott döntését vitatja, további fontos tényekre vagy a körülmények jelentős megváltozására hivatkozva kifogásolhatja az ügy 19. cikk szerinti elfogadhatóságát."

92 Részletes ismertetését lásd később A komplementaritás és a Biztonsági Tanács által kezdeményezett eljárások címú fejezetben.

93 Részletes ismertetését szintén lásd később A komplementaritás és a Biztonsági Tanács által kezdeményezett eljárások címú fejezetben.

94 Római Statútum 53. cikk (3) bekezdés a) pont: „Azügyeta 14. cikk szerint a Bíróság eléterjesztőÁllam, vagy a 13. cikk b) pontja szerinti esetben a Biztonsági Tanács kérésére, a tárgyalás-előkészitó tanács felülvizsgálhatja a fóügyésznek az (1) és (2) bekezdés szerint az eljárás meginditásának megtagadásáról hozott határozatát, és kérheti a fóügyészt annak újbóli megvizsgálására." 
tekintve, hogy a statútum a joghatóság gyakorlására ilyen esetekben csak felhatalmazza, de nem kötelezi (,joghatóságát gyakorolhatja”).

(i) A Biztonsági Tanács eljárásának materiális feltételét illetően azt mondhatjuk, hogy e norma első ránézésre alacsonynak túnő mércét állapít meg: „egy vagy több bû́ntett” elkövetését várja el. Azonban ez csak első ránézésre van így, hiszen az ICC tárgyi joghatóságába tartozó bû́ncselekmények tényállásainak szemrevétele után felismerhetô, hogy félrevezető a 13. cikk b) pont szerinti megfogalmazás. A népirtás tényállása az elkövetési magatartásról akként rendelkezik, hogy „a jelen Statútum alkalmazásában, a népirtás büntette alatt bármelyik következő cselekmény értendö, amelyet valamely nemzeti, etnikai, faji vagy vallási csoport, mint olyan, teljes vagy részleges megsemmisitésének szándékával követnek el" (Római Statútum 6. cikk). A genocídium tehát szükségszerúen széles körben és nagy arányban valósul meg a bủncselekmény célzata miatt („teljes vagy részleges megsemmisités szándéka"). Az emberiesség elleni búncselekmények tényállása akkor teljesül, ha "a polgári lakosság elleni átfogó vagy módszeres támadás részeként, a támadásról tudva” [Római Statútum 7. cikk (1) bekezdés] követik el azokat. A háborús bủncselekmények tényállásának chapeau-ja [Római Statútum 8. cikk (1) bekezdés] is hasonló logikával bír annyiban, hogy a búntett elkövetési magatartásához hozzátartozik, hogy „a Bíróság joghatósággal rendelkezik a háborús büntettek vonatkozásában, különösen akkor, amikor ezeket a büntetteket tervszerüen vagy politika részeként követik el, illetőleg ilyen büntettek tömeges elkövetésének részei". ${ }^{95}$

(ii) A 13. cikk b) pont alkalmazhatóságának másik feltétele, hogy a BT az ENSZ Alapokmány VII. fejezete alapján járjon el, azaz nemcsak a Római Statútum ezen cikkének, hanem az Alapokmány 39. cikkének („A Biztonsági Tanács megállapítja a béke bárminő veszélyeztetésének vagy megszegésének, vagy bárminő támadó cselekménynek fennforgását") is eleget kell tennie.

(iii) A harmadik kritériumról elmondható, hogy az ICC-nek akkor sem kötelező az eljárást megindítania, ha az első két feltétel fennáll, tekintve, hogy a Római Statútum a bíróságot a joghatóság gyakorlására ilyen esetekben csak felhatalmazza, ellenben nem kötelezi. A Nemzetközi Büntetőbíróság előtti eljárások első lépése - tekintet nélkül az eljárást indító mechanizmusra -, hogy a főügyész elrendeli az előzetes vizsgálatot. Ezután - ahogyan a Főügyészi Hivatal eloozetes vizsgálatokról szóló szakpolitikai dokumentumában leszögezi - a nyomozás megindítása nem automatikus, akár részes állam, akár a Biztonsági Tanács utal helyzetet a bíróság elé. ${ }^{96} \mathrm{~A}$ nyomozás elrendelése - azaz az eljá-

95 Trahan, 2013, 420-421. o.

96 Office of the Prosecutor: Policy Paper on Preliminary Examinations, November 2013, \$4, elérhető: https://www. icc-cpi.int/iccdocs/otp/OTP-Policy_Paper_Preliminary_Examinations_2013-ENG.pdf [Letöltve: 2019. 12. 01.]. 
rások megindítása előtt, az előzetes vizsgálatok során - a föügyésznek a Római Statútum 53. cikk (1) bekezdése ${ }^{97}$ értelmében mérlegelnie kell a joghatóság fennállását, a helyzet elfogadhatóságát (komplementer joghatóság és a bűncselekmények tárgyi súlya), valamint azt, hogy az eljárás megindítása az igazság érdekét szolgálja-e. És még ha a fentiekre a Főügyészi Hivatal rá is bólint, a tárgyalás-előkészítő tanácsnak engedélyeznie kell a nyomozást (illetve amennyiben nem engedélyezte, a tárgyalás-előkészítő tanácsnál jogorvoslathoz lehet folyamodni). ${ }^{98}$ A 13 . cikk b) pontjának e helyütt vizsgált fordulata azért kardinális jelentőségû, mert a főügyész és a tárgyalás-előkészítő tanács mérlegelési jogköre hivatottak biztosítani a Nemzetközi Büntetőbíróság intézményi autonómiáját a politikai elfogultság és önkényes szelekció vádjával szemben.

További kérdésként jelentkezhet, hogy adódhat-e olyan helyzet, amikor a Biztonsági Tanácsnak arra vonatkozó kötelezettsége áll fenn, hogy a 13. cikk b) pontjában foglaltak szerint eljárjon? Már elöljáróban le kell szögezni, hogy a Római Statútum ilyen kötelezettséget nem támaszt - és nem is támaszthatna - a BT-vel szemben. ${ }^{99}$ Noha a statútum tartalmaz normákat az eljárást indító mechanizmusokra nézve, önmagában véve nem hatalmazhatja fel vagy kötelezheti a Biztonsági Tanácsot olyasmire, amire egyébként a BT az ENSZ Alapokmánya alapján nem jogosult vagy nem kötelezett. Bár az Alapokmány erre vonatkozó konkrét kötelezettséget nem tartalmaz, utalásokat igen. Az 1. cikk (3) bekezdése ${ }^{100}$ a szervezet céljai között rögzíti az emberi jogok és alapvető szabadságok mindenki részére tekintet nélkül történő tiszteletben tartását. A VII. fejezet alapján meghozott aktusok értelemszerüen nem vezethetnek az emberi jogok sérelméhez és összhangban kell állniuk az Alapokmány céljaival - kvázi a nemzetközi jog alapelveivel (államok szuverén egyenlősége, belügyekbe való beavatkozás tilalma, erőszak alkalmazásának tilalma, viták békés rendezése, államok együttmüködési kötelezettsége, kötelezettségek jóhiszemű teljesítése és népek önrendelkezési joga). ${ }^{101}$ Azonban még ha a VII. fejezet alkalmazását a béke

97 Római Statútum 53. cikk (1) bekezdés: „1. A fö̈̈gyész a hozzá eljuttatott információ értékelése után meginditja a nyomozást, kivéve, ha úgy dönt, hogy a jelen Statútum szerint az eljárás megindítása nem megalapozott. A határozathozatal során a fö̈̈gyész figyelembe veszi, hogy:

a) A birtokában lévó adatok alapján alaposan feltehetô-e, hogy a Bíróság joghatósága alá tartozó büntettet követtek vagy követnek el;

b) Az ügy a 17. cikk szerint elfogadható-e, vagy az lenne-e; és

c) A cselekmény súlyára és a sértettek érdekeire tekintettel, alapos okkal feltehetö-e, hogy a nyomozás nem szolgálná az igazságszolgáltatás érdekét."

98 Trahan, 2013, 424. o.

99 Stahn, 2003, 97. 0.

100 ENSZ Alapokmány 1. cikk (3) bekezdés: „Az Egyesült Nemzetek célja, hogy gazdasági, szociális, kulturális vagy emberbaráti jellegü nemzetközi feladatok megoldása útján, valamint az emberi jogok és az alapvetô szabadságok mindenki részére, fajra, nemre, nyelvre vagy vallásra való tekintet nélkül történő tiszteletben tartásának előmozditása és támogatása révén nemzetközi együttmüködést létesítsen."

101 Rosand, 2004, 556. o. 
veszélyeztetése, megszegése vagy támadó cselekmény fennforgása váltja is ki, nem áll fenn explicit kötelezettség a BT-re nézve.

Érdekes észrevételnek túnik, hogy az Alapokmány 39. cikkének nyelvezete formálisan kötelezi („shall”) a Biztonsági Tanácsot a fentiek megállapítására és a 41-42. cikkek szerinti kényszerintézkedések foganatosítására, ám a gyakorlatban ez nem kötelezettségként mutatkozik meg a BT oldalán - még ha az ENSZ főszervét a védelmi felelősség elmulasztása miatt éri is kritika -, ami a 40-42. cikkek ${ }^{102}$ diszpozitív nyelvezetéből („may”) már jobban kitúnik. Így bár az ENSZ Alapokmánya az elsődleges felelősséget a nemzetközi béke és biztonság megóvása vonatkozásában a Biztonsági Tanácsra ruházza, és deklarálja a BT kötelezettségét erre nézve [Alapokmány 24. cikk (2) bekezdés ${ }^{103}$ ], melyekből az következik, hogy a föszervnek el "kellene” járnia a béke veszélyeztetése, megszegése vagy támadó cselekmény fennforgása esetén, a 40-42. cikkek konkretizáló rendelkezései rácáfolnak erre az abszolút követelményre. ${ }^{104}$

A Biztonsági Tanács által a Nemzetközi Büntetôbíróság elé utalt helyzetek lényeges ellentmondásokra, gyakorlati problémákra világítottak rá. Az ezzel kapcsolatos első felismerés már a BT 13. cikk b) pontja alapján hozott határozatainak olvasata és nyelvtani elemzése után rögtön jelentkezik, mely rendelkezés lehetővé teszi a Biztonsági Tanács számára, hogy a nemzetközi békét és biztonságot veszélyeztetô vagy sértő helyzeteket terjesszen az ICC elé, aktiválva ezzel a bíróság joghatóságát tekintet nélkül arra, hogy részes vagy nem részes állam állampolgára, illetve részes vagy nem részes fél államterületén követték el a bíróság tárgyi joghatóságába tartozó deliktumokat. ${ }^{105}$

102 ENSZ Alapokmány 40. cikk: „A Biztonsági Tanács - a helyzet súlyosbodásának megakadályozása végett - mielőtt a 39. cikk értelmében ajánlásokat tenne, vagy rendszabályok felöl határozna, felhivhatja az érdekelt feleket, hogy alkalmazkodjanak azokhoz az ideiglenes rendszabályokhoz, amelyeket szükségesnek vagy kivánatosnak itél. Az ilyen ideiglenes rendszabályok az érdekelt felek jogait, igényeit vagy helyzetét semmiben sem érintik. A Biztonsági Tanács az ilyen ideiglenes rendszabályok végrehajtásának elmulasztását megfelelően számontartja"; valamint ENSZ Alapokmány 42. cikk: „Ha a Biztonsági Tanács úgy találja, hogy a 41. cikkben emlitett rendszabályok elégtelenek, vagy elégteleneknek bizonyulnak, úgy légi, tengeri és szárazföldi fegyveres erökfelhasználásával olyan müveleteket foganatosithat, amelyeket a nemzetközi béke és biztonság fenntartásához vagy helyreállitásához szükségesnek itél. Ezek a müveletek az Egyesült Nemzetek tagjainak légi, tengeri és szárazföldi hadereje által foganatositott tüntetô felvonulásból, zárlatból (blokád) vagy egyéb müveletekböl is állhatnak."

103 ENSZ Alapokmány 24. cikk (2) bekezdés: „A Biztonsági Tanácsnak e kötelességei teljesitése során az Egyesült Nemzetek céljaival és elveivel összhangban kell eljárnia. Azt a különleges hatáskört, amellyel a Biztonsági Tanács ezeknek a kötelességeknek teljesitése végett fel van ruházva, a VI., VII., VIII. és XII. fejezetek határozzák meg."

104 Trahan, 2013, 426. o.

$105 \mathrm{Az}$ azonban a szakirodalomban már tû́ri a vitát, hogy ilyen esetben a BT joghatóságot teremt valamennyi tekintetben, vagy pusztán a Római Statútum 12. cikkében szereplő előfeltételek figyelmen kívül hagyását alapozza meg. A két álláspont közötti különbség többek között az időbeli joghatóságnál nyerhet relevanciát. A joghatóság-teremtés elfogadása esetén a bíróság olyan búntettek esetén is jogosult lenne eljárni, amelyeket azelőtt követtek el, hogy a statútum hatályba lépett az adott államban vonatkozásában. Lásd: Milanović, 2011, 25-52. o. 
A Biztonsági Tanács a 13. cikk b) pontjában szereplő hatáskörével e sorok írásáig kétszer élt: először 2005-ben, amikor az 1593. (2005) határozatával ${ }^{106}$ az ICC elé utalta a dárfúri konfliktust, majd 2011-ben, amikor az 1970. (2011) határozatával ${ }^{107}$ a líbiai arab tavasz eseményeit terjesztette a bíróság elé. Mindkét helyzetben a határozatok megszületését nemzetközi vizsgálóbizottságok felállítása előzte meg (Dárfúr) vagy követte (Líbia), ${ }^{108}$ melyek arra a következtetésre jutottak, hogy észszerú gyanú áll fenn arra nézve, hogy ezen államokban ${ }^{109}$ népirtást, emberiesség elleni, illetve háborús búncselekményeket követtek el.

\subsection{Dárfúr helyzete a Nemzetközi Büntetőbiróság előtt, avagy az 1593. (2005) BT-határozat megszületése}

Nem vitás, hogy a XX. század második felétől kezdődően a Biztonsági Tanács játssza a fôszerepet a nemzetközi béke és biztonság fenntartásában, melynek egyik ékes bizonyítéka a 2005. március 31-én elfogadott BT-határozat, amely felhatalmazta a Nemzetközi Büntetőbíróság főügyészét, hogy indítson nyomozást a dárfúri humanitárius katasztrófa során történt súlyos nemzetközi jogi jogsértések vonatkozásában.

A határozat megszületése hatalmas mérföldkő az ICC történetében, figyelembe véve, hogy a Római Statútum hatálybalépése (2002. július 1-je) után ez volt az első olyan alkalom, amikor a BT konfliktusos helyzetet utalt az újonnan megalakult büntetôbírói fórum elé. A dárfúri eset a negyedik helyet foglalta el a bíróság elótti helyzetek sorában, mindazonáltal megjegyzésre tart számot, hogy mivel a korábbiakban a Római Statútumban részes államok - Uganda, a Kongói Demokratikus Köztársaság és a Közép-afrikai Köztársaság"10 - saját joghatóságuk alá tartozó eseménysorozatot terjesztettek az ICC felé, így Nyugat-Szudán helyzete számos újszerû kihívással szembesítette a bíróságot.

A Dárfúrtól Hágáig vezetô út legelső mozzanata Szudán kudarcával jellemezhető, minthogy az állami feladatok gyors számbavétele után megállapítható, hogy valamennyi állam köteles egyfajta védelmi funkciót betölteni állampolgárai életében, azaz meg-

106 UN Doc. S/RES/1593 (31 March 2005).

107 UN Doc. S/RES/1970 (26 February 2011).

108 Líbia esetében a határozatot rekordgyorsasággal, mindössze néhány nap alatt fogadták el, így a vizsgálóbizottság felállítása és a bủntettek gyanúját igazoló bizonyítékok beszerzése néhány hónap késéssel, a határozat meghozatala után történt meg.

109 Report of the International Commission of Inquiry on Darfur to the United Nations Secretary General, UN Doc. S/2005/60 (1 February 2005), \$568.; Report of the International Commission of Inquiry to investigate alleged violations of international human rights law in the Libyan Arab Jamahiriya established pursuant to UN Human Rights Council, UN Doc. A/HRC/17/44 (1 June 2011), \$ 7 .

110 Schabas, 2017, 36-57. o. 
védeni a lakosságot mind az államhatáron kívülrôl jövő támadásokkal, mind a belső zavargásokkal, esetleges polgárháborúkkal szemben. Ezen túl bizonyos szolgáltatások nyújtására is köteles, mint például az alapvető egészségügyi ellátás és oktatás biztosítása, a közlekedési és kommunikációs infrastruktúra fenntartása, vagy a belső viták békés rendezése, vagyis a független és pártatlan igazságszolgáltatás. ${ }^{111} \mathrm{Ha}$ a fenti feltételek teljesítésére egy állam nem képes, az önmagában is markáns problémaként jelentkezik belső jogában, azonban ha a hiányosságok az állam szándékos jogsértő cselekményeinek egyenes következményeiként állnak elő, azaz az állam a fentiek teljesítésére nem is hajlandó, akkor számot tarthat a nemzetközi közösség figyelmére, és adott esetben beavatkozására.

A szudáni humanitárius katasztrófa ${ }^{112}$ kibontakozásában az állami vezetés szerepvállalása kulcsfontosságú volt, mely szoros összefüggésbe hozható Omar al-Bashír volt szudáni államfő fanatikus jogi szemléletével, aki az etnikailag kettéosztott lakosságra a tálib stílusú iszlám jogot alkalmazta, és diszkriminálta a nem muzulmán vallású állampolgárokat, főképp az afrikai őslakosokat. A bíróság előtti bûncselekményeket felölelő nem nemzetközi fegyveres összeütközés 2003 februárjában kezdődött azzal, hogy néhány lázadó csoport - a Szudáni Felszabadító Hadsereg (Sudan Liberation Army), majd később az Igazságért és Egyenlőségért Mozgalom (Justice and Equality Movement) - nyíltan megvádolta az arab irányítású kormányzatot az afrikai őslakosok arab etnikummal szembeni elnyomásával. Emiatt az SLA megtámadta a kormányzati katonai erőket 2003 áprilisában, El Fesher környékén. Mivel a szudáni kormány nem rendelkezett megfelelő haderővel a támadás legitim visszaszorítására, így válaszképpen arab harcosokból álló spontán csapatokat toborzott, amelyek késóbb dzsandzsavíd ${ }^{113}$ (Janjaweed) milíciákként váltak ismertté. A kormány tevőleges támogatását élvezve a dzsandzsavídek a lázadókkal azonos etnikumú községeket és civil lakosokat vettek célba, akiknek sérelmére széles körủ és szisztematikus jelleggel emberölést, nemi erőszakot, fosztogatást és erőszakos elhurcolást követtek el, falvak százait tették a földdel egyenlővé, és megfertőzték az őslakos közösségek ivóvizét. ${ }^{114}$

A példátlanul kegyetlen kormányzati reakció hamarosan világszerte a médiafigyelem fókuszába került, ami rákényszerítette a BT-t, hogy fogadjon el egy határozatot, ${ }^{115}$ amiben felszólítja az ENSZ fôtitkárát - mely tisztséget ekkoriban Kofi Annan töltötte be -, hogy sürgősen szorgalmazza egy nemzetközi vizsgálóbizottság létrehozását a Dárfúrban történt

111 Dunlap, 2004, 453-458. o.

112 Cryer, 2006, 196-198. o.

113 A kifejezés szó szerinti jelentése 'ördögök lóháton'.

114 Udombana, 2005, 1-57. o.

115 UN Doc. S/RES/1564 (18 September 2004). 
súlyos emberi és humanitárius jogi jogsértések kivizsgálására, a gyanúsítottak azonosítására, továbbá a cselekmények büntetőjogi minősítésére. A Biztonsági Tanács azután kezdett el tevékenyebben foglalkozni a dárfúri humanitárius katasztrófával, miután Colin Powell, az Egyesült Államok egykori külügyminisztere felszólalt a Kongresszus egyik bizottsági ülésén. A csádi menekülttáborokban tartózkodó túlélők egybehangzó nyilatkozataira hivatkozva Powell felvetette a térségben történtek vonatkozásában a népirtás gyanúját, valamint ezzel kapcsolatban - az 1948. évi Genocídium-egyezményt, illetve a népirtás ius cogens természetú szokásjogi normáját idézve -, Szudán esetleges felelősségét a nemzetközi jogsértések vonatkozásában. ${ }^{116}$ Powell az 1948. évi Genocídium-egyezmény VIII. cikkére ${ }^{117}$ hivatkozva fordult az ENSZ-hez: a rendelkezés felhatalmazza a részes államokat, hogy felszólítsák a szervezet illetékes szerveit a megfelelő lépések megtételére, amennyiben a népirtás vagy az egyezményben felsorolt egyéb cselekmények megelőzése vagy megbüntetése érdekében ezt indokoltnak látják.

A határozattal felállított Dárfúri Nemzetközi Vizsgálóbizottságg18 (International Commission of Inquiry on Darfur) a helyszínen lefolytatott vizsgálat után megerősítette a jogsértő cselekmények elkövetését, mely a szudáni kormányzat felkelésre adott válaszreakciója volt a civil lakossággal szemben. Beszámolt arról is, hogy a dzsandzsavíd milíciák múködése egyértelmúen összefüggésbe hozható a kormánnyal, amely rendszeresen támogatta élelemmel és fegyverrel az irreguláris csapatokat. A vizsgálóbizottság továbbá megerősítette, hogy a dzsandzsavíd csapatok tömegesen támadtak meg falvakat Dárfúrban, és hogy e cselekmények a polgári lakosság elleni széles körú és szisztematikus támadásnak minősülnek, így súlyos nemzetközi jogi jogsértéseket valósítanak meg. ${ }^{119} \mathrm{~A}$ vizsgálóbizottság becslései alapján másfél év alatt mintegy másfél millió embert telepítettek át lakóhelyéről, több mint kétszázezren menekültek át a szomszédos Csádba, valamint több száz falvat pusztítottak el vagy égettek porig a térségben. Viszonyításképpen érdemes hozzátenni, hogy Dárfúr lakosságszáma ekkoriban megközelítőleg hatmillió fó volt. ${ }^{120}$ Mivel a bizottság az ország

116 U.S. Department State Archive: The Crisis in Darfur: Hearing Before the Senate Foreign Relations Committee, elérhetô: https://findit.state.gov/search?query=The+Crisis+in+Darfur\%3A+Hearing+Before+the+Senate+Foreign+Relations+Committee\&affiliate $=2017-2021$. state.gov [Letöltve: 2015 . 11. 26.]

117 Genocídium-egyezmény VIII. cikk: „Bármely Szerződő Fél az Egyesült Nemzetek Szervezete illetékes szerveihez fordulhat annakérdekében, hogy ezek az Egyesült Nemzetek Alapokmányának megfelelöen olyan rendszabályokat foganatositsanak, amelyek véleményük szerint alkalmasak a népirtás, vagy a III. cikkben felsorolt egyéb cselekmények bármelyikének megelőzésére és megszüntetésére."

118 Cryer, 2006, 199. o.

119 International Commission of Inquiry on Darfur: Report of the International Commission of Inquiry on Darfur to the United Nations Secretary-General, Pursuant to Security Council Resolution 1564 of September 2004, elérhető: https://www.un.org/news/dh/sudan/com_inq_darfur.pdf [Letöltve: 2016. 03. 17.].

120 U.S. Department State Archive: Documenting Atrocities in Darfur, elérhető: https://2001-2009.state.gov/g/ $\mathrm{drl} / \mathrm{rls} / 36028 . h$ htm [Letöltve: 2016.03 . 18.]. 
igazságszolgáltatási rendszerét az elkövetők felelősségre vonására alkalmatlannak találta, így szorgalmazta a Biztonsági Tanácsnál, hogy utalja a konfliktust az ICC elé, mert a cselekmények lefedik a Római Statútum 5. cikkében ${ }^{121}$ meghatározott büntető anyagi jogi tényállásokat.

A határozat elfogadására ${ }^{122}$ tizenegy igen és négy tartózkodó szavazat érkezett a Biztonsági Tanácsban. ${ }^{123} \mathrm{Az}$ Egyesült Királyság, Franciaország és Oroszország - állandó tagok -, valamint Argentína, Benin, Dánia, Görögország, Japán, a Fülöp-szigetek, Románia és Tanzánia - nem állandó tagok - szavaztak a határozat elfogadása mellett, míg az Egyesült Államok és Kína - állandó tagok -, valamint Algéria és Brazília - nem állandó tagok - tartózkodtak a szavazástól. A határozat elfogadása az Egyesült Államok és Kína esetleges vétója miatt látszott a leginkább kétségesnek, mivel e két nagyhatalom máig nem részes állama a Római Statútumnak, és előszeretettel élnek - megalapozott vagy megalapozatlan - ellenvetésekkel az ICC múködésével kapcsolatban.

A szavazás után Kína ENSZ-képviselője, Wang Guangya azzal indokolta az állam tartózkodását, hogy az ICC joghatóság-gyakorlásához hozzá kellett volna járulnia a szudáni kormányzatnak is, azonban azt már nem fejtette ki bővebben, hogy mégis miért járult volna hozzá - az egyébiránt kérlelhetetlen - kartúmi vezetés, hogy egy nemzetközi büntetôbírói fórum mondjon verdiktet felette. E ponton okvetlenül szükséges Kína érdekeltségéról is szólni néhány szót, mivel a fentebb vázolt etnikai ellentéteken túlmenően a gazdasági érdekek is fontos szerepet játszottak a konfliktus kirobbanásában és elmélyülésében. A kőolajban gazdag délnyugati területek függetlenségi törekvései feszült aggodalmat keltettek a kartúmi vezetésben, mivel al-Bashír kormánya 2001-ben koncessziós szerződést kötött a Kínai Nemzeti Kőolaj Vállalattal (Chinese National Petroleum Corporation), amelyben a déldárfúri régiót jelölték meg az olaj fô kitermelési területeként, majd e megállapodás megkötését követően jelentős kínai jelenlét jellemezte az érintett térséget. A szudáni kormány és a távol-keleti ország kőolajérdekeltségei szoros összefüggésbe kerültek egymással: utóbbi

121 Római Statútum 5. cikk: „(I) A Bíróság joghatósága a nemzetközi közösség egészétérintőlegsúlyosabb büntettekre korlátozódik. A Bíróság joghatósága a jelen Statútum szerint a következő büntettekre terjed ki:

a) a népirtás büntette;

b) az emberiesség elleni büntettek;

c) a háborús büntettek;

d) az agresszió büntette."

122 Cryer, 2006, 198-205. o.

123 A Biztonsági Tanácsnak összesen tizenöt tagja van, melyből öt állandó és tíz nem állandó. Az állandó tagok: az Egyesült Államok, az Egyesült Királyság, Franciaország, Kína és Oroszország. A nem állandó tagokat a méltányos földrajzi megoszlás elvének megfelelően kétévente választják, ám mandátumuk nem egyszerre jár le, hanem évente öt-öt állam cserélődik. Egy határozat meghozatalához legalább kilenc igenlő szavazat szükséges, az állandó tagok vétóval rendelkeznek azzal, hogy a politikai testület egyhangúan határoz. Lásd: Sulyok, 2009. 
előbbi legnagyobb kőolajexportőrévé (55\%), egyúttal Kína Szudán legnagyobb fegyverimportőrévé vált $(90 \%){ }^{124}$

Az Egyesült Államok jogi álláspontja kapcsán Condoleezza Rice külügyminiszter arról adott számot 2005. április 1-jén, hogy Washington továbbra is tartja a nézetet, miszerint népirtás folyik az északkelet-afrikai térségben, és ezért a bünösöket felelősségre kell vonni. ${ }^{125}$ Azonban az Egyesült Államok kitartott amellett is, hogy a megoldást Dárfúr számára egy hibrid törvényszék felállítása jelentené. Ugyanakkor mivel az USA elismerte annak jelentőségét, hogy a nemzetközi közösségnek egységesen kell fellépnie a hatékony felelősségre vonás érdekében, így nem alkalmazott vétót a határozat meghozatalával szemben. ${ }^{126}$

Ami a nem állandó tagokat illeti, Algéria a szavazástól való tartózkodását később azzal indokolta, hogy nem az ICC-t, hanem az Afrikai Uniót tartja a legalkalmasabb fórumnak az elszámoltatásra. Az intézmény akkori kapacitását figyelembe véve azonban aligha lehetett volna amellett meggyőzően érvelni, hogy a regionális szervezet helyre tudta volna állítani a régióban a tartós békét, és hogy igazságot tudott volna szolgáltatni az áldozatok számára. Bár az a nézet idealisztikusnak tûnhet, hogy hagyni kell Afrikát önállóan megoldani a saját belső konfliktusait, mindazonáltal az AU megfelelő kapacitás és infrastruktúra hiányában nem lett volna képes a probléma önálló orvoslására. Erre kitűnő példaként szolgál, hogy a szervezet egy hétezer fôs missziót (African Mission in the Sudan) delegált a dárfúri civilek megsegítésére, ám a krízis méreteit figyelembe véve ez az intézkedés egyáltalán nem nevezhető érdeminek. ${ }^{127}$

A négy tartózkodó állam közül Brazília ellenérve még a fentieknél is gyengébbnek bizonyult: az 1593. (2005) BT-határozat 6 . cikkére hivatkozott, amely úgy rendelkezik, hogy azok a személyek, akik részt vettek a BT vagy az AU szudáni missziójában és nem szudáni állampolgárok, ugyanakkor valamelyik Római Statútumban nem részes állam állampolgárai, nemzetközi bủncselekmény elkövetése esetén kizárólag az állampolgárság szerinti állam joghatósága alá tartozzanak, kivéve ha ez az állam expressis verbis lemondott az ICC javára kizárólagos joghatóságának gyakorlásáról. Brazília szerint a BT ezzel lehatárolta a bíróság joghatóságát, így e cikk miatt a határozat meghozatala gyengítette az ICC pozícióját a nemzetközi büntető igazságszolgáltatásban. Való igaz, hogy

124 Kelly, 2011-2012, 206-210. o.

125 Condoleezza Rice, U.S. Secretary of State: Remarks with Hungarian Foreign Minister Ferenc Somogyi After Meeting at the Treaty Room in the White House on April 1, 2005, elérhető: https://2001-2009.state.gov/secretary/rm/2005/44104.htm [Letöltve: 2016. 03. 17.].

126 Udombana, 2005, 8-11. o.

127 Az Afrikai Unió Szudáni missziójáról lásd bővebben a Human Rights Watch honlapját: https://www.hrw.org/ report/2006/01/19/sudan-imperatives-immediate-change/african-union-mission-sudan [Letöltve: 2021. 04 . 21.]. 
a BT - mint politikai szerv - nem rendelkezik tisztán igazságszolgáltatási kérdésekben való döntési hatáskörrel, ugyanakkor az is könnyen belátható, hogy a fentebbi érv meglehetősen paradox állítást takar, hiszen a határozat meghozatala - tartalmától függetlenül - nemhogy gyengítette, hanem megerősítette a bírói fórum nemzetközi színtéren játszott szerepét. ${ }^{128}$

Az 1593. (2005) BT-határozat megszületése ${ }^{129}$ több szempontból is különös jelentőséggel bír. Elfogadásával Kína és az USA - még ha hallgatólagosan is - tudomásul vette a Nemzetközi Büntetôbíróság múködését. Emellett a BT elismerte a bíróság nemzetközi büntető igazságszolgáltatásban betöltött főszerepét, illetőleg mellékszerepét a nemzetközi béke és biztonság fenntartásában. Ezentúl legitimitást nyert, hogy a Nemzetközi Bírósághoz hasonlóan, az ICC is arra hivatott, hogy élen járjon a nemzetközi rend törvényességének és tisztességességének fenntartásában. Továbbá a határozattal a politikai testület azt is kifejezésre juttatta, hogy kompetensnek tartja a bíróságot a dárfúri helyzettel kapcsolatos nyomozás és büntetőeljárás lefolytatására. Végül, de nem utolsósorban a dárfúri helyzet egyértelmú üzenetet küldött a nemzetközi emberi és humanitárius jogi normák jövőbeli megsértőinek, azaz, hogy a „büntetlenség korszakának” egyszer és mindenkorra vége: a nemzetközi bűncselekmények többé nem tû́rnek toleranciát. ${ }^{130}$

\subsection{Líbia helyzete a Nemzetközi Büntetőbíróság előtt, avagy az 1970. (2001) BT-határozat megszületése}

2011-ben az arab tavasz ${ }^{131}$ forradalmak és tüntetések hosszú sorát hozta magával a Közel-Keleten és Észak-Afrika szerte. Ezek egyike volt a líbiai polgárháború, amely véget vetett Moammer Kadhafi több mint negyven évig tartó diktatórikus uralmának. ${ }^{132} \mathrm{~A}$ demonstrációk terrorba torkollása ugyanakkor nemcsak a líbiai nép, hanem a nemzetközi büntetőjog és az egész nemzetközi közösség számára is emlékezetes maradt: Líbia helyzetét a Biztonsági Tanács 1970. (2011) határozata az ICC elé utalta, elítélve az államban azokat a 2011. február 15. és október 23. között történt súlyos és rendszeres emberi jogi jogsértéseket, amelyek a Kadhafi rezsimje elleni békés tüntetések, majd felkelések erőszakos és véres leverése során öltöttek testet.

128 Udombana, 2005, 13-14. o.

129 Cryer, 2006, 203-205. o.

130 Udombana, 2005, 22. o.

$131 \mathrm{Az}$ arab tavasz történetét lásd részletesebben a History oldalán: https://www.history.com/topics/middle-east/arab-spring [Letöltve: 2021. 04. 21.].

132 Ajami, 2012 [Online]. 
A BT a Római Statútum 13. cikk b) értelmében csupán magát a konfliktusos helyzetet utalta a nemzetközi büntetôbírói fórum elé, melyből a Főügyészi Hivatal által lefolytatott vizsgálatok után három konkrét ügy rajzolódott ki. Az ICC föügyésze az alábbi terheltek vonatkozásában bocsátott ki letartóztatási parancsot: maga a de facto államfó, Kadhafi; Líbia tényleges miniszterelnöke - Kadhafi legidősebb fia és várható utódja -, Szajf al-Iszlám Kadhafi; illetve a katonai titkosszolgálat vezetője és a líbiai fegyveres erők ezredese, Abdullah al-Senussi ellen. Mivel időközben Kadhafit lázadók egy csoportja a szirti csatában meggyilkolta, ${ }^{133}$ valamint al-Senussi ügyét az ICC elfogadhatatlannak nyilvánította, ${ }^{134}$ így jelenleg a fenti vádlottak közül már csak Szajfal-Iszlám Kadhafi ellen folyik eljárás a bíróság előtt. ${ }^{135} \mathrm{~A}$ tárgyalás-előkészítő tanács úgy találta, alapos gyanú áll fenn arra vonatkozóan, hogy Szajf Kadhafi 2011. február 15. és 28. között közvetett társtettesként emberiesség elleni büncselekményeket (szándékos emberölés és üldözés) követett el. Mindazonáltal a terhelt mind a mai napig nem került a bíróság őrizetébe, ugyanis Líbia - az egyébként joghatósággal rendelkező állam - arra hivatkozva, hogy a nemzeti hatóságok lefolytatták a megfelelő büntetőeljárást, nem adta át a vádlottat az ICC-nek.

Líbia mai „arculata” 1934-ben, három eltérő történeti hagyományokkal rendelkező régióból alakult ki: a nyugati Tripolitániából, a sivatagi Fezzánból és a keleti Kireneikából. ${ }^{136}$ Az 1951-ben megalakult monarchiát és az uralkodó, Ídrisz király hatalmát Kadhafi ezredes 1969-ben nacionalista-szocialista színezetú pánarab katonai puccsa döntötte meg. Kadhafi egészen 2011-ig, az arab tavasz derekán kirobbant polgárháború befejezéséig gyakorolta a Líbia államfójének járó jogköröket, amely már önmagában véve - a hatalomra kerülés körülményeire való tekintettel - a rezsimet illegitim alapokra helyezte.

A rendszer azonban tartalmilag is messze alulmaradt a demokratikus jogállamiság által közvetített nemzetközi sztenderdektől. Kadhafi alkotmányos deklarációja, az ún. Zöld Könyv kikiáltotta a „tömegek államát” - amelyet más szóval dzsamahirijának neveztek -, és az iszlám jog elótérbe helyezésével a líbiai népet polgári és politikai jogaitól teljes mértékben megfosztották. A diktatórikus érában nem számított ritkaságnak sem a kínzás, erőszakos eltûnés és elhúzódó magánelzárás alkalmazása, sem a hủtlenséggel

$133 \mathrm{Az}$ egykori diktátor haláláról lásd bővebben a Human Rights Watch honlapját: https://www.hrw.org/report/2012/10/16/death-dictator/bloody-vengeance-sirte [Letöltve: 2021. 04. 21.].

134 Bishop, 2013, 388-421. o.

135 Később az ICC tárgyalás-előkészítő tanácsa al-Tuhamy Mohamed Khaled és Mahmoud Mustafa Busayf al-Werfalli ellen adott ki letartóztatási parancsot 2013-ban, illetve 2017-ben és 2018-ban, ugyanakkor további eljárási cselekmények azóta egyik ügyben sem történtek. Lásd: https://www.icc-cpi.int/libya/gaddafi [Letöltve: 2020. 05. 26.].

$136 \mathrm{Az}$ észak-afrikai ország történetéről lásd bővebben a Britannica honlapját: https://www.britannica.com/place/Libya [Letöltve: 2021.04 .21 .]. 
gyanúsított állampolgárok kivégzése, sem pedig a büntető-igazságszolgáltatás megcsúfolása. Kadhafi rezsimjének groteszk, ugyanakkor élethú portréját Sadiq Hamed Shwehdi esete szemléletesen lefesti. Shwehdi disszidens volt, akit rendszerellenes politikai tevékenységéért 1984-ben tartóztattak le. Nem sokkal később tárgyalását egy országszerte sugárzott televíziós show-músor keretein belül Bengázi kosárlabda-stadionjából élőben közvetítették, majd a gyorsított eljárás lefolytatása után ott a helyszínen - a közönség szeme láttára - felakasztották. ${ }^{137}$

A Kadhafi rendszere elleni törzsi lázadások 2011. február 15-én kezdődtek Bengáziban, miután Fathi Terbílt, a nyíltan rendszerkritikus ügyvédet kormánybarát erők nyomására őrizetbe vették. A megmozdulások kelettől nyugat felé haladva az egész ország területére kiterjedtek, és rövid idő leforgása alatt a kezdeti békés demonstrációk elsöprő és véres polgárháborúvá eszkalálódtak. A szembenálló feleket a Líbiai Arab Dzsamahiríja és az Átmeneti Nemzeti Tanács képezték. Az ellentüntető́k főképp a régi rendszer, Ídrisz király monarchista híveiből verbuválódtak, ideológiailag a szenusszi szektához tartoztak, székhelyük pedig Kireneika volt. A tripoli székhelyû́ kormányzat késedelem és mindennemú könyörület nélkül lépett fel az események ellen, ami - becslések alapján - 25-30 ezer ember halálát és további négyezer ember eltúnését vonta maga után. ${ }^{138}$

A líbiai események miatti fellépést elsőként Ibrahim Dabbashi helyettes ENSZ-képviselő sürgette, megoldásként javasolva, hogy a bíróság indítson nyomozást a Kadhafi által esetlegesen elkövetett emberiesség elleni és háborús búntettek gyanúja okán. Bár Líbia nem részes állama a Római Statútumnak, a BT - látványos gyorsasággal - 2011. február 26-án kelt határozatával az államban 2011. február 15. óta fennálló polgárháborús konfliktust egyhangúan az ICC elé utalta. A BT 1970. (2011) határozata az ENSZ Alapokmányának VII. fejezete és a Római Statútum 13. cikk b) pontjának felhatalmazása alapján felszólította a líbiai hatóságokat a bírósággal való teljes körú együttmúködésre, továbbá tehetővé tette, hogy az ICC a Líbia államterületén vagy állampolgárai által elkövetett népirtás, emberiesség elleni vagy háborús büntettek vonatkozásában a fent nevesített naptól kezdődően joghatóságot gyakoroljon. Kicsivel később megszületett egy másik BT-határozat is, mely a civil lakosság védelme érdekében Líbia elleni kényszerintézkedésként az ország felett repüléstilalmi zónát állított fel. ${ }^{139}$

Az ICC föügyésze által lefolytatott vizsgálatok és a Líbiai Nemzetközi Vizsgálóbizottság jelentése ${ }^{140}$ után a tárgyalás-elókészítő tanács megállapította: fennáll az alapos

137 Mayer, 2012-2013, 365-387. o.

138 Bishop, 2013, 405. o.

139 UN Doc. S/RES/1973 (17 March 2011).

140 United Nations Human Rights Office of the High Commissioner, Report of the International Commission of Inquiry on Libya, elérhető: https://www.ohchr.org/Documents/HRBodies/HRCouncil/RegularSession/Session19/A.HRC.19.68.pdf [Letöltve: 2016. 05. 23.]. 
gyanúja, hogy 2011 elején az állam vezetése kormányzati szintú politikát alkalmazott a rendszer elleni megmozdulások leverésére és a lázadók elrettentésére, és hogy ennek keretében a Líbiai Biztonsági Erők országszerte - főképp Tripoliban, Miszrátában és Bengáziban - a lázadóknak vélt polgári lakosság sérelmére széles körú és szisztematikus emberi jogi jogsértéseket követtek el. Szintén megállapítást nyert, hogy Szajf Kadhafi annak ellenére, hogy semmiféle hivatalos állami tisztséget nem töltött be, Moammer Kadhafi belső körének legbefolyásosabb embere volt a kérdéses időszakban, így tényleges hatalommal bírt az államapparátus jelentős része felett - mind pénzügyi, mind logisztikai értelemben -, és de facto miniszterelnöki jogköröket gyakorolt, az elnyomás kifejtéséhez tevékenyen hozzájárulva.

2011. május 16-án az ICC föügyésze emberiesség elleni büncselekmények feltehető elkövetése - emberölés és üldözés ${ }^{141}$ - miatt indítványozta a tárgyalás-előkészítő tanácsnál a Moammer Kadhafi, Szajf Kadhafi és al-Senussi elleni letartóztatási parancsok jóváhagyását, melyek kibocsátására 2011. június 27-én került sor. Időközben azonban Szajf Kadhafit 2011. november 19-én irreguláris milíciák Zintanban fogságba ejtették, Moammer Kadhafival szemben pedig a Föügyészi Hivatal 2011. november 22-én a vádakat ejtette és az eljárást megszüntette, mivel lázadók egy csoportja a szirti csatában megölte.

\subsection{A Biztonsági Tanács 1593. (2005) és 1970. (2011) határozatainak értelmezése}

A soron következő lényegi kutatási kérdés a Biztonsági Tanács eljáráskezdeményező határozatainak nyelvtani értelmezése tükrében fogalmazódik meg, azaz hogy milyen rendelkezéseket tartalmaznak e határozatok, és milyeneket (nem) kellene tartalmazniuk?

Az 1593. (2005) és az 1970. (2001) BT-határozatokkal kapcsolatban háromféle lényegi bírálatot lehet megfogalmazni: (i) az első a kezdeményezett eljárások költségeinek viseléséhez fúződik, mivel a BT mindennemú ENSZ-finanszírozás folyósítását befagyasztotta a dárfúri és líbiai helyzetek vonatkozásában; (ii) a második a joghatóság-gyakorlással kapcsolatos: a BT kizárta az ICC eljárási képességét a nem részes államok állampolgárai felett; (iii) a harmadik pedig a bírósággal való együttmúködést érinti: a BT csak a fegyveres konfliktussal érintett államokat - Szudánt és Líbiát - kötelezte, hogy a Római Sta-

141 Római Statútum 7. cikk (1): „A jelen Statútum alkalmazásában az emberiesség elleni büntettek alatt bármelyik következő cselekmény értendö, amelyet a polgári lakosság elleni átfogó vagy módszeres támadás részeként, a támadásról tudva követnekel:

a) Szándékos emberölés; [...]

h) Bármely meghatározható csoport vagy közösség üldözése a 3. bekezdésben meghatározott politikai, faji, nemzeti, etnikai, kulturális, vallási, nemi vagy más, a nemzetközi jog által egyetemesen tiltottegyéb ismérv alapján, a jelen bekezdésben írt bármely cselekménnyel, vagy a Bíróságjoghatósága alá tartozó bármely más büntettel kapcsolatban." 
tútumban nem részes államokként múködjenek együtt a bírói fórummal, a többi harmadik államra ilyen kötelezettséget nem rótt.

\subsubsection{Az eljárások finanszírozásának kizárása}

A rendelkezésre álló pénzügyi források „szúkössége” és a bíróság előtt folyó előzetes vizsgálatok és büntetőeljárások egyre növekvő száma okán komoly aggodalmat keltett a Nemzetközi Büntetőbíróság tisztviselőiben és a Római Statútum részes államaiban, hogy a Biztonsági Tanács eljáráskezdeményező határozatai az ENSZ-től érkező finanszírozás lehetőségét kategorikusan kizárták. ${ }^{142} \mathrm{~A}$ határozatok ezen rendelkezései szembementek mindkét intézmény közös céljával, azaz hogy a büntetőjogi felelősségre vonás az ad hoc törvényszékek által generált magas költségek mellőzésével valósulhasson meg.

Az erre vonatkozó 7. cikk bekerülése az 1593. (2005) határozatba az Egyesült Államok az iránti aggályának visszatükröződése volt, hogy az általa folyósított ENSZ-befizetést ${ }^{143}$ nehogy a Nemzetközi Büntetőbíróság megsegítésére fordítsák. Ezen aggályt továbbá az is jól szemlélteti, hogy az USA-ban hatályban van egy olyan törvény, amely az ICC pénzügyi támogatását kifejezetten megtiltja. ${ }^{144}$ És bár a BT állandó tagjaként, az Egyesült Államoknak viselnie kellene a felelősséget az ICC elé terjesztett büntetőeljárásokért, ez sem a dárfúri, sem a líbiai helyzet tekintetében nem történt meg - így az eddig felmerülő költségeket a Római Statútumban részes felek állták. ${ }^{145}$

A Római Statútum rendelkezései között nem található olyan norma, melynek értelmében a BT kezdeményezte eljárásokat az ENSZ-nek kellene finanszíroznia. Ilyen tartalmú szabály inkorporációjára természetesen azért sem kerülhetett volna sor, mert a BT-t és a KGY-t csak az ENSZ Alapokmánya kötelezheti - egyéb nemzetközi szerződéseknek erre nincsen módjuk. Mindazonáltal hipotetikus helyzetként elképzelhető ebből adódóan

142 Mistry és Verduzco, 2012 [Online].

143 Ez 2018-ban az ENSZ adminisztrációs összköltségeinek 22\%-a, míg a békefenntartással kapcsolatos költségek $28 \%$-a volt. Lásd: Hillard és Shendruk, 2020 [Online].

144 Admiral James W. Nance and Meg Donovan Foreign Relations Authorization Act (H.R. 3427), Public Law No. 106-113. (29 November 1999), \$\$705-706, elérhető: https://www.cfr.org/article/funding-united-nationswhat-impact-do-us-contributions-have-un-agencies-and-programs [Letöltve: 2019. 12. 09.].

1452005 és 2019 között a bíróság a dárfúri és líbiai helyzetekre fordított számszerúsíthető közvetlen kiadásai mintegy 56 millió eurót (becsült összeg) tettek ki, mely nem foglalja magában a jelentősebb, ám mennyiségileg nem kifejezhető közvetett költségeket (ezek hozzávetőleg az egyes konfliktusos helyzetekként évente 20 millió eurót tesznek ki). És bár a Részes Államok Közgyưlése éves költségvetésének tervezetét a tárgyévet megelőző év nyarán elfogadja és közzéteszi, majd a tárgyévet megelőző év végén a végleges költségvetését elfogadja és közzéteszi, ezekben számszerűen nem szerepel a BT által előterjesztett helyzetekre fordított kiadások összege, így az egyes helyzetek költségeire csupán az előirányzott kiadások struktúrája enged következtetni. Lásd: Proposed Programme Budget for 2020 of the International Criminal Court, elérhető: https:// asp.icc-cpi.int/iccdocs/asp_docs/ASP18/ICC-ASP-18-10-ENG.pdf [Letöltve: 2019. 11. 15.]. 
az a problémás következmény, hogy ha a Biztonsági Tanács egymás után több helyzetet is az ICC elé terjesztene pénzbeli támogatás kísérete nélkül, a bíróságnak komoly problémával kellene szembenéznie, ugyanis nem állna rendelkezésére elegendő anyagi forrás ahhoz, hogy az elé terjesztett szituációk kapcsán a büntetőeljárást lefolytassa. Ez alapján Kevin Jon Heller azt a következtetést vonja le, hogy fennáll annak az abszurd lehetősége, hogy egy újabb BT kezdeményezte eljárás esetén a föügyész a Római Statútum 53. cikk (1) bekezdés c) pontjára ${ }^{146}$ hivatkozva meg sem indítaná a nyomozást, tekintve, hogy a bíróság úgyis képtelen lenne az ezzel járó költségek fedezésére. ${ }^{147} \mathrm{~A}$ Biztonsági Tanács tagjainak tehát - különösen azoknak, akik részes felek a Római Statútumban, mint például az Egyesült Királyság és Franciaország - az eljárások zavartalan lefolytatása érdekében nem lenne szabad hagyniuk az ilyen tartalmú rendelkezések határozatba foglalását, a BT-nek pedig praktikus szempontból a Közgyưlésre kellene hagynia a finanszírozás folyósításának eldöntését.

2011-ben a Részes Államok Közgyûlése is foglalkozott a BT elôterjesztéseinek anyagi kérdéseivel, amikor is a líbiai helyzettel kapcsolatos nem várt kiadások arra szorították a bíróságot, hogy e költségeket a tartalékalapból fedezzék. Az ASP Költségvetési és Pénzügyi Bizottsága ezt követő jelentésében kihangsúlyozta, hogy az ICC relevanciája indokolná az ENSZ támogatását, minthogy a bíróság nemzetközi büntető igazságszolgáltatásban játszott szerepéből az egész nemzetközi közösség profitál. A jelentés az ENSZ Közgyúlésével folytatott párbeszéd kívánalmát is felvetette az anyagi terhek jövőbeni csökkentése céljából. ${ }^{148}$ Megállapítható, hogy a 115. cikkben ${ }^{149}$ lefektetett normatív kerettel ellentétben az ICC a gyakorlatban arra kényszerült, hogy saját finanszírozásáért „lobbizzon” - ennek érdekében a bíróság az ENSZ Titkárságához fordult, egyelőre szemmel látható eredmény nélkül. ${ }^{150}$

Az anyagi támogatás folyósításának hiánya kihatással van az ügyészi függetlenségre is. İgy például ugyanebben az évben a föügyész jelezte, hogy a líbiai helyzet kapcsán indítható

146 Római Statútum 53. cikk (1) bekezdés c) pont: „A cselekmény súlyára és a sértettek érdekeire tekintettel, alapos okkal feltehetô-e, hogy a nyomozás nem szolgálná az igazságszolgáltatás érdekét."

147 Heller, 2013 [Online].

148 Report of the Committee on Budget and Finance on the Work of its Sixteenth Session, ICC-ASP/10/15, 17 June 2011 (Tenth Session of the Assembly of States Parties), \$23.

149 Római Statútum 115. cikk: „Bíróságnakés a Részes Államok Közgyülése üléseinek költségeit, ideértve a Végrehajtó Testület és a kiegészítő szervek költségeit, a Részes Államok által elfogadott költségvetés szerint, a következő forrásokból kell fedezni:

a) A Részes Államok megállapitott hozzájárulásaiból;

b) Az Egyesült Nemzetek által rendelkezésre bocsátott alapokból, a Közgyülés jóváhagyása mellett, különösen a Biztonsági Tanács által a Bíróság elé utalt ügyekböl származó költségek vonatkozásában."

150 Verduzco, 2015, 41. o. 
nyomozás a bíróság rendelkezésére álló források függvénye, mely kitűnően illusztrálja az ICC költségvetése és a politikai irányítása közötti összefüggést. ${ }^{151}$

Érdekességként kínálkozik annak a megítélése is, hogy a Biztonsági Tanácsnak van-e egyáltalán hatásköre az ENSZ költségvetésével kapcsolatos döntések meghozatalára? ${ }^{152}$ Az Egyesült Nemzetek Alapokmányának 17. cikke ${ }^{153}$ ugyanis egyértelmúen leszögezi, hogy a szervezet költségvetését a KGY vizsgálja meg és hagyja jóvá, ami arra engedhet következtetni, hogy a többi főszervnek és a szakosított intézményeknek erre nézve nincsen hatásköre. Azonban a fenti kérdés megválaszolása mégsem olyan egyértelmú, ha felsejlenek elöttünk a BT VII. fejezetben foglalt hatáskörei, valamint a Nemzetközi Bíróság az Egyesült Nemzetek bizonyos költségeinek ügyében ${ }^{154}$ adott tanácsadó véleménye, mely utóbbiban az ICJ hangsúlyozta, hogy a nemzetközi békével és biztonsággal kapcsolatos költségek meghatározása tekintetében a Közgyúlés hatásköre korlátozott, mivel az ENSZ Alapokmány 11. cikk (2) bekezdése ${ }^{155}$ szerint „[...] minden olyan kérdést, amely a nemzetközi béke és biztonság fenntartására vonatkozik [...] a Közgyülésnek a vita elött, vagy azután a Biztonsági Tanács elé kell terjesztenie".

És még ha a Biztonsági Tanács - ultra vires vagy sem - meg is vonja az ICC elé terjesztett eljárásoktól az ENSZ-finanszírozást, az sem világos normatív szempontból, hogy a KGY-t a BT-határozatok kötik-e? A Biztonsági Tanács határozatai az ENSZ-tagállamokra nézve értelemszerúen kötelező erôvel bírnak, ami a Közgyưlés - mint egy, a tagállamokétól elkülönült jogalanyisággal rendelkező nemzetközi szervezet főszerve - viszonylatában már nem szükségképpen igaz. ${ }^{156}$

151 Second Report of the Prosecutor of the ICC to the UN Security Council pursuant to UNSCR 1970 (2011), Office of the Prosecutor, 2 November 2011, \$53.

152 A Biztonsági Tanács - esetleges támogató hozzáállása esetén - arra rendelkezett volna hatáskörrel, hogy az ENSZ Titkárságának közremúködésével kérelmezi a Közgyưlés Ötödik Bizottságától (Adminisztrációs és Költségvetési Bizottság) az általa előterjesztett konfliktusos helyzetek finanszírozását, tekintve, hogy a Közgyủlés semmilyen kiadást nem hagyhat jóvá addig, amíg az Ötödik Bizottság nem hagyta azt jóvá. Lásd: UN General Assembly Rules of Procedure, Rule 153, UN Doc. A/520/Rev.15, elérhető: https://www.un.org/Depts/ DGACM/Uploaded\%20docs/rules\%20of\%2oprocedure\%20of\%20ga.pdf [Letöltve: 2019. 11. 15.].

153 ENSZ Alapokmány 17. cikk: „(1) A Közgyülés megvizsgálja és jóváhagyja a Szervezet költségvetését.

(2) A Szervezet költségeit a tagok a Közgyülés által megállapitott arányban viselik.

(3) A Közgyülés megvizsgálja és jóváhagyja az 57. Cikkben emlitett szakositott intézményekkel kötött pénzügyi és költségvetési megállapodásokat, és megvizsgálja az ilyen szakositott intézmények igazgatásának költségvetését is abból a célból, hogy az illető intézménynek ajánlásokat tehessen."

154 Certain Expenses of the United Nations, Advisory Opinion of 20 July 1962, I.C.J. Reports 1962.

155 ENSZ Alapokmány 11. cikk (2) bekezdés: „A Közgyülés minden olyan kérdést, amely a nemzetközi béke és biztonság fenntartására vonatkozik és amelyet az Egyesült Nemzetek valamelyik tagja vagy a Biztonsági Tanács vagy a 35. Cikk 2. pontja értelmében olyan Állam terjeszt eléje, amely az Egyesült Nemzeteknek nem tagja, megvitathat, és az ilyen kérdések tekintetében a 12. Cikkben foglalt eset kivételével ajánlásokat tehet az érdekelt Államnak vagy Államoknak, a Biztonsági Tanácsnak, vagy mind azérdekelt Államnak vagy Államoknak, mind a Biztonsági Tanácsnak. Minden olyan kérdést, amelyben cselekvésre van szükség, a Közgyülésnek a vita elött, vagy azután a Biztonsági Tanács elé kell terjesztenie." 156 Moss, 2012 [Online]; Cryer, 2006, 206-207. o. 
A fenti kérdések végleges eldöntésének elkerülése mellett ugyanakkor megjegyzendő, hogy a Római Statútum 115. cikk b) pontja ${ }^{157}$ a Közgyúlés kompetenciájára utal a pénzügyi források kapcsán, és hasonló mondható el az ENSZ és az ICC között köttetett együttmúködési megállapodásról [13. cikk (1) bekezdés] is. ${ }^{158}$ Annyi bizonyos, szerencsésebb lett volna, ha a Biztonsági Tanács az 1593. (2005) határozat 7. cikkét és az 1970. (2011) határozat 8. cikkét mellőzi, és a fentebb ismertetett doktrinális vitáknak elejét veszi. Továbbá megfontolásra érdemes lenne az esetleges jövőbeli eljáráskezdeményezések esetén, ha a BT-határozatok egyáltalán nem tartalmaznának a finanszírozással kapcsolatos megszorító rendelkezéseket.

\subsubsection{A joghatóság kizárása}

Ami talán még a BT kezdeményezte eljárások pénzügyi támogatásánál is több kritikai megjegyzést kapott a nemzetközi jogi szakirodalomban, az a Római Statútumban nem részes államok állampolgárainak kivétele az ICC joghatósága alól: a határozatokban ugyanis - a jövőbeni terheltek állampolgárságának leszúkítésével - limitálták a bíróság személyi joghatóságát.

Mindkét határozat 6. cikkébe - az Afrikai Unióra vonatkozó kiegészítést belecsempészve Dárfúr esetén - szó szerint ugyanazt a rendelkezést építették be. Ezek lényege, hogy azon konfliktusban részt vevő, főképp békefenntartó természetes személyek felett, akiket a BT vagy az Afrikai Unió delegált, az állampolgárság szerinti állam kizárólagos joghatóságot gyakorol, és az ICC csak abban az esetben vonhatja őket felelősségre, ha az állampolgárság szerinti állam a személyi elv alapján gyakorolható joghatóságáról kife-

157 Római Statútum 115. cikk b) pont: „Bíróságnak és a Részes Államok Közgyúlése üléseinek költségeit, ideértve a Végrehajtó Testület és a kiegészitô szervek költségeit, a Részes Államok által elfogadott költségvetés szerint, a következő forrásokból kell fedezni [...] az Egyesült Nemzetek által rendelkezésre bocsátott alapokból, a Közgyúlés jóváhagyása mellett, különösen a Biztonsági Tanács által a Bíróság elé utalt ügyekből származó költségek vonatkozásában." E helyütt megjegyzendő, hogy bár a Római Statútum 115. cikkének nyelvezete ugyanazt a terminológiát használja a részes államok megállapított hozzájárulásai és az ENSZ által rendelkezésre bocsátott alapok vonatkozásában - mely nem is annyira a magyar fordításból, sokkal inkább a hiteles angol szövegből és a „shall” segédige használatából rajzolódik ki -, a statútum nem írhat elő jogi kötelezettséget az ENSZ számára (tekintve, hogy az ENSZ mint nemzetközi szervezet nem részes fél a Római Statútumban). E rendelkezés nyelvezete voltaképpen egy kompromisszumos megoldást tükröz azon államok között, akik a lassú ratifikációs folyamat és az ENSZ-finanszírozás hiánya miatt a bíróság de facto múködésképtelenségétôl tartottak, valamint azon államok között, akik az ENSZ legfontosabb befizetői és a bíróság kötelező támogatásának legelhivatottabb ellenzői voltak. Lásd: Verduzco, 2015, 40. o.

158 Lásd: Article 13 (1) of the Negotiated Relationship Agreement between the International Criminal Court and the United Nations, ICC-ASP/3/Res.I (4 October 2004), elérhető: https:/www.icc-cpi.int/NR/rdonlyres/916FC6A2-7846-4177-A5EA-5AA9B6D1E96C/0/ICCASP3Res1_English.pdf [Letöltve: 2019. 12. 09.]. 
jezetten lemond. E fenti kitétel a Római Statútum elveivel szöges ellentétben áll, ${ }^{159}$ mivel csorbát ejt a bíróság függetlenségén és az ügyészség vádmonopóliumán, elhintve a szelektivitás magjait, valamint erősítve a politikai potenciállal rendelkező államok által előidézhető kettős mérce alkalmazását.

Az előző pont alatt írtak után talán nem meglepő, hogy e rendelkezés határozatokba foglalása is elsősorban az Egyesült Államoknak köszönhető, ${ }^{160}$ aki azzal érvelt, hogy azért látja szükségét e norma bevezetésének, mert olyan katonai potenciállal rendelkezik, amivel más államok nem. ${ }^{161} \mathrm{~A}$ kivételt megállapító rendelkezés az USA belső jogával ${ }^{162}$ összhangban került bele a határozatokba, eleve kizárva az ENSZ békefenntartó múveleteiben részt vevő amerikai állampolgárokat a Nemzetközi Büntetőbíróság joghatósága alól. Tartalmi szempontból a norma célja a Római Statútum 12. cikk (2) bekezdés a) pontjának "hatástalanítása” volt, mely a területi elv értelmében joghatóságot biztosít az ICC-nek akkor is, ha részes állam, illetve ez esetben a bíróság elé utalt nem részes állam területén nem részes fél állampolgárával szemben merül fel népirtás, emberiesség vagy háborús büntettek elkövetésének alapos gyanúja.

Érdekesnek tûnik felvillantani, hogy a dárfúri határozat elfogadásakor egyedül Brazília - mint a BT nem állandó tagja - tartózkodott a szavazás során, arra hivatkozva, hogy indokolatlan és szükségtelen az immunitásra vonatkozó efféle kitétel. ${ }^{163}$ Hat évvel később Brazília is csatlakozott a líbiai határozatot egyhangúan megszavazó BT-hez, ám erôteljes fenntartásainak továbbra is hangot adott. ${ }^{164}$

Bár az USA katonai potenciálra vonatkozó érve tartalmilag igaz, a határozatok kivételt biztosító 6 . cikkeihez jogilag meggyőző indokként aligha szolgál, tekintve, hogy a határozatok elfogadásakor nem állt fenn amerikai békefenntartókkal szemben a nemzetközi büntetőeljárás esélye: 2005-ben még csak az Afrikai Unió békefenntartói állomásoztak Szudánban, mivel az UNAMID-ot, melynek költségeihez az Egyesült Államok is rendszeresen hozzájárult, két évvel a határozat elfogadása után, 2007-ben hozták létre. Így a rendelkezés inkorporálásából az a következtetés vonható le, hogy valódi célja a Nemzetközi Büntetőbíróság joghatóságának pro futuro korlátozása volt. ${ }^{165} \mathrm{~A}$ harmadik államok

159 Annak dacára, hogy a Római Statútum 13. cikk b) pontja kimondja, hogy „a biróság joghatóságát egy, az 5. cikkben meghatározott büntett tekintetében a jelen statútum rendelkezései szerint akkor gyakorolhatja", mely kitétel arra utal, hogy a Római Statútum rendelkezéseit akkor is be kell tartani, ha a Biztonsági Tanács kezdeményezi az eljárást.

160 Trahan, 2013, 454-453. o.

161 Lietzau, 2001, 125-129. o.

162 American Service Members' Protection Act of 2002, elérhető: https://legcounsel.house.gov/Comps/aspao2. pdf [Letöltve: 2019. 09. 27.].

163 Statement of Ambassador Sardenberg, UNSC $5158^{\text {th }}$ meeting (31 March 2005), UN Doc. S/PV/5158, 11. 164 Statement of Ambassador Viotti, UNSC 6491st meeting (26 February 2011), UN Doc. S/PV/6491, 7.

165 Verduzco, 2015, 37. o. 
„kiemelése" a statútumban részes feleket heves vitákra gerjesztette, mivel úgy látták, ez egyrészt kivételezést valósít meg velük szemben, ${ }^{166}$ másrészt különösen aggályosnak látták, hogy a BT három állandó tagja (Kína, Oroszország és az USA) szavazhat az ICC elé utalandó helyzetekről és az eljárások felfüggesztéséről (kifejtését részletesen lásd a következőkben), de közben kivonják az amerikai, kínai és orosz állampolgárokat (is) a bíróság eljárása alól.

A nemzetközi büntetőjogi szakirodalom hasábjain további kérdésként merült fel, hogy a Nemzetközi Büntetőbíróság föügyészét és bíráit kötik-e a Biztonsági Tanács határozataiban foglaltak akkor, ha azok nem állnak összhangban a Római Statútummal? Az ICC által alkalmazandó jogról a statútum 21. cikk (1) bekezdése ${ }^{167}$ rendelkezik, mely felsorolás a BT határozatait az alaki jogforrások között nem említi. ${ }^{168}$ Továbbá, a statútum 13. cikk b) pontja egy absztrakt helyzet bíróság elé terjesztésének lehetőségéről rendelkezik, e BT-határozatok pedig nem absztrakt helyzeteket, hanem „békefenntartókkal csökkentett esetköröket" utalnak az ICC elé. ${ }^{169}$ Figyelembe kell-e tehát vennie a bíróságnak a joghatóság efféle korlátozását? Számos szerző úgy érvel, hogy mivel a határozatok a fentiek tekintetében nem állnak konformitásban a Római Statútum 13. cikk b) pontjával, így a bíróságnak sem kellene konformitásban állnia a határozatban foglaltakkal. ${ }^{170}$

A Fő̈ugyészi Hivatal korábban már elutasította az „egyoldalú" joghatóságon alapuló eljáráskezdeményezést: amikor Uganda saját helyzetét a bíróság elé terjesztette, kísérletet tett rá, hogy csak az Úr Ellenállási Hadseregének cselekményei képezzék az ICC tárgyi joghatóságának alapját. Ugyanakkor a Főügyészi Hivatal az előzetes vizsgálatokról szóló 2013. évi szakpolitikai dokumentumában felhívta a figyelmet a Római Statútum 14. cikk (1) be-

166 Cryer, 2006, 217. o.; Papenfuss, 2013 [Online].

167 Római Statútum 21. cikk (1) bekezdés: „A Bíróság a következőket alkalmazza:

a) Elsősorban a jelen Statútumot, a Büncselekmények Tényállási Elemeit, továbbá az Eljárási és Bizonyítási Szabályokat;

b) Másodsorban, adott esetben, az ügyben alkalmazandó egyezményeket és a nemzetközi jog alapelveit és szabályait, ideértve a nemzetközi jognak a fegyveres konfliktusokra vonatkozó, általánosan elismert alapelveit;

c) Ha ez nem lehetséges, a Bíróság által a világ jogrendszereinek nemzeti szabályaiból levezetett általános jogelveket, ideértve, adott esetben, azoknak az Államoknak a nemzeti jogát, amelyek egyébként általában joghatósággal rendelkeznének a büntett tekintetében, ha ezek a jogelvek nem ellentétesek a jelen Statútummal, a nemzetközi joggal, továbbá a nemzetközileg elismert normákkal és követelményekkel."

168 A BT-határozatok figyelmen kívül hagyása a nemzetközi jog jogforrási katalógusaiban ugyanakkor nem egyedülálló: a Nemzetközi Bíróság Statútumának 38. cikke sem tesz említést róluk, ahogy az egyoldalú állami aktusokról sem. Ennek ellenére a szakirodalomban nem füződhet ma kétség utóbbi kettő normatív erejéhez.

169 Trahan, 2013, 458. o.

170 Papenfuss, 2013, 3. o.; Kaye, 2013 [Online]; Heller, 2013 [Online]; Bergsmo és Perić, 2008, 600. o. 
kezdésére („Bármely Részes Állam a fö̈ügyész elé terjeszthet olyan esetet, ${ }^{171}$ amelyben vélhetöen a Bíróság joghatóságába tartozó egy vagy több büntettet követtek el, arra kérve a föügyészt, hogy vizsgálja ki az ügyet annak eldöntésére, hogy egy vagy több meghatározott személy ellen kell-e vádat emelni ezen büntettek elkövetése miatt.") és arra, hogy az esetek konkretizálása és a vádemelés a föügyész kizárólagos hatáskörébe tartozik, azon sem a részes államok, sem a BT nem ejthetnek

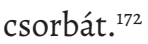

\subsubsection{Az ENSZ-tagállamok együttmúködési kötelezettségének hiánya}

Az 1593. (2005) és az 1970. (2011) BT-határozatok nyelvtani értelmezése során jelentkező harmadik neuralgikus kérdés az ENSZ-tagállamok együttmüködési kötelezettségének hiánya. E határozatok Szudánt és Líbiát - mint harmadik államokat - kötelezik a bírósággal való együttmúkködésre, ám a többi ENSZ-tagállammal kapcsolatban ilyen tartalmú kötelezettségrôl nem rendelkeznek.

Utóbbinak két szempontból lett volna kiemelkedő jelentősége: valamennyi, a Római Statútumban nem részes államnak kötelező lett volna az ICC-vel együttmúködnie, továbbá a részes államoknak nem csupán a Római Statútumból eredt volna az együttmüködési kötelezettsége, hanem az ENSZ Alapokmányából, mely utóbbinak 103. cikke elsőbbséget biztosított volna e kötelezettségnek bármely más szerződéses kötelezettségükkel szemben.

Különös jelentőségú jogi problémaként jelentkezik, hogy a határozatok nyelvezete e tekintetben is kontraproduktívan hat a bíróság eljárására, különösképpen az elfogatóparancsok végrehajtására. Mivel azonban az együttmúködés hiányából adódó problémának e könyv a későbbiekben önálló fejezetet szentel, így e ponton most részletesebb elemzésére nem kerül sor.

171 A törvényjavaslatot szó szerint idézem, továbbra is felhívva a figyelmet a magyar fordítás pontatlanságára.

172 Office of the Prosecutor, Policy Paper on Preliminary Examinations (November 2013), \$\$ 34-71, elérhetö: https://www.icc-cpi.int/iccdocs/otp/OTP-Policy_Paper_Preliminary_Examinations_2013-ENG.pdf [Letöltve: 2019 . 12. 10.]. 


\section{A Nemzetközi Büntetőbíróság előtti eljárás megindítása a Római Statútum 15bis és 15ter cikkei alapján}

\subsection{A Rómától Kampaláig vezető út}

„Sosem szabad felednünk, ahogyan ítéletet mondunk e vádlottak felett a mai napon, úgy fog a történelem ítéletet mondani felettünk a holnapin. Ha most méregpoharat nyújtunk e vádlottaknak, azt a saját ajkunkhoz is emeljük"173 - hallatta Robert Jackson bíró 1945-ben, a nürnbergi per második napján, ${ }^{174}$ amikor első ízben került rá sor, hogy nemzetközi büntetóbíróság előtt indult eljárás „béke elleni büncselekmény”175 miatt. Ugyanakkor nagyon sokáig kellett arra várnia a nemzetközi közösségnek, hogy az agresszió bűncselekményére többé már nem kell kihunyt vulkánként tekintenünk, hanem azt mondhatjuk, hogy az állandó Nemzetközi Büntetőbíróság joghatóságot gyakorol felette.

Az agresszió kérdése kétségkívül a római diplomáciai konferencia legnagyobb adóssága volt, ${ }^{176}$ amit a Római Statútum első felülvizsgálati konferenciáján rendezni kellett. Erre utalt a statútum - immár hatályon kívül helyezett - 5. cikk (2) bekezdése, miszerint: „A Bíróság joghatóságát az agresszió tekintetében akkor gyakorolja, ha a 121. és 123. cikkeknek megfelelóen elfogadásra került az a rendelkezés, amely meghatározza az agresszió büntettének fogalmátés azokat a feltételeket, amelyek megléte esetén a Bíróság itélkezhet a büntett ügyében. A rendelkezésnek az Egyesült Nemzetek Alapokmányának megfelelö rendelkezéseivel összhangban kell állnia." Az első felülvizsgálati konferencia összehívásának kötelezettségét - a Római Statútum hatálybalépése után hét évvel - a 123. cikk (1) bekezdése ${ }^{177}$ rögzítette az ENSZ fótitkára számára, amin ${ }^{178}$ - a fent idézett rendelkezésekkel összhangban - el is fogadták az agresszió bưntettének fogalmát. ${ }^{179}$ Annak érdekében, hogy egy, a részes államok által széles körben elfogadható definíció születhessen, a Részes Államok Közgyűlése létrehozta az agresszióval foglalkozó különleges munkacsoportját (Special Working Group on the Crime

173 Nuremberg Trial Proceedings Vol. II, 21 November 1945.

174 Idézi: Clark, 2015, 778. o.

175 Az agresszió fogalmi előképe, még a klasszikus nemzetközi jog terminológiája.

176 Clark, 2010, 689. o.

177 Római Statútum 123. cikk (1) bekezdés: „A jelen Statútum hatálybalépése után hét évvel az Egyesült Nemzetek Főtitkára Felülvizsgálati Konferenciát hív össze a jelen Statútum módosításainak megvitatása céljából. A felülvizsgálat kiterjedhet, többek között, de nem kizárólagosan, az 5. cikkben szabályozott büntettekre. A Konferencia azonos feltételekkel nyitva áll a Részes Államok Közgyülésének valamennyi résztvevője elött."

$178 \mathrm{Az}$ első felülvizsgálati konferenciára az ugandai Kampalában került sor 2010. május 31. és június 11. között. 179 The Crime of Aggression, ICC Resolution RC/Res.6, 11 June 2010. 
of Aggression), ${ }^{180}$ melynek feladatául túzte ki a felülvizsgálati konferencián bemutatandó rendelkezéstervezetek elkészítését.

Az SWGCA 2003 és 2009 között számos alkalommal ülésezett, és az általa előkészített normaszöveg-tervezetek - melyeket az SWGCA utolsó jelentésie ${ }^{181}$ foglalt össze - lettek a kampalai tárgyalások kiindulópontjai. Utóbbiak később kiegészültek az ASP és az SWGCE utolsó elnöke, Zeid Ra’ad Zeid al-Husszein herceg - késóbbi ENSZ Emberi Jogi Főbiztos - által egyeztetett informális javaslatokkal. ${ }^{182}$ Az SWGCA utolsó jelentése két kiegészítő rendelkezést tartalmazott a 2002. július 1-jén hatályba lépett Római Statútumhoz képest: a „8bis cikk” az agresszió büncselekményének fogalmát rögzítette, míg a „15bis cikk” a joghatóság gyakorlásának feltételeit - tehát az első normaszöveg-tervezet az anyagi jogi, a második az eljárásjogi kérdéseket vázolta fel.

\subsection{Az agresszió büntettével kapcsolatos anyagi jogi kérdések}

Az SWGCA által javasolt „8bis cikk” nem tartalmazott alternatívákat, csupán azt az egyetlen verziót, amit a kampalai felülvizsgálati konferencián végül szó szerint elfogadtak. ${ }^{183} \mathrm{~A}$ rendelkezés tartalmát illetôen fontos kiemelni, hogy az különbséget tesz az „agresszió bűncselekménye” (crime of aggression) és az „agresszió cselekménye” (act of aggression) között, utat nyitva az egyének büntetőjogi felelősségének az államok - továbbra is fennálló felelössége mellett. ${ }^{184}$

Így a Római Statútum 8bis cikk (1) bekezdése először kimondja, hogy „jelen Statútum értelmében az agresszió büncselekménye »olyan agressziós cselekmény tervezése, elókészitése, meginditása vagy kivitelezése, amely jellegénél, súlyosságánál vagy kiterjedtségénél fogva az Egyesült Nemzetek Alapokmányának nyilvánvaló megsértését jelenti, olyan személy részéröl, aki pozíciójánál fogva tényleges ellenőrzést gyakorol egy állam politikai vagy katonai akciója felett, vagy irányítja azt« «"15," majd

180 A különleges munkacsoportban való részvétel lehetősége nemcsak a Római Statútumban részes államok, hanem valamennyi állam előtt nyitva állt. Lásd: Continuity of Work on the Crime of Aggression, ICC-ASP/1/ Res.1, 9 September 2002.

181 Report of the SWGCA, ICC-ASP/7/SWGCA/2, 20 February 2009.

182 Non-paper by the Chairman on the Elements of Crimes, ICC-ASP/INF.2, 28 May 2009, Annex II, Informal inter-sessional meeting on the Crime of Aggression 8-10 June 2009, Liechtenstein Institute on Self-Determination, Woodrow Wilson School, Princeton Club.

183 Rome Statute ASP RC/Res.6, 11 June 2010.

184 Utóbbi elbírálása értelemszerúen nem az ICC, hanem más nemzetközi bírói fórumok joghatósága alá tartozik. Az azonban már a nürnbergi per során kikristályosodott, hogy e súlyos nemzetközi jogi jogsértések mögött természetes személyek, nem pedig absztrakt entitások állnak, és csak akkor lehet az államokat jogkövető magatartásra rábírni, ha az egyénekkel szemben elrettentő hatású felelősségre vonást helyeznek kilátásba. Lásd: Judicial Decisions: International Military Tribunal (Nuremberg), Judgment and Sentences, American Journal of International Law, 1947/41, 172, 221.

185 Hoffmann Tamás fordítása. Lásd: Hoffmann, 2019, 65. o. 
a 8bis (2) bekezdése az ENSZ KGY 3314. (XXIX) határozatában ${ }^{186}$ kodifikált definíciót kölcsönözve megismétli, hogy „jelen cikk (1) bekezdése értelmében az agresszió cselekményének olyan fegyveres erő alkalmazása valamely állam részéröl egy másikállam szuverenitása, területi integritása vagy politikai függetlensége ellen vagy az Egyesült Nemzetek Alapokmányának céljaival össze nem egyeztethető bármely más módon", továbbá felsorolja a Közgyúlés határozatában példálózva felsorakoztatott agressziós tényállásokat is. ${ }^{187}$

A Római Statútum megőrizte a KGY-határozat koncepcióját az agresszió és az erőszak elhatárolását illetően, tudniillik az utóbbinak csupán a súlyosabb formái tartoznak az előbbi alá: az agressziónak minden formája fegyveres erőszak, de a fegyveres erőszaknak nem minden formája agresszió. ${ }^{188}$ Mindazonáltal a 3314. (XXIX) KGY-határozat gyakorlati „átemelése” felvetett néhány jelentős kodifikációval kapcsolatos aggályt, mivel e határozat alapján a Biztonsági Tanács széles körú diszkrecionális jogkört élvez az agresszió cselekménye tekintetében, azaz valamely agressziós tényállás pro forma megvalósulása esetén nem köteles az agressziót megállapítani, egyszersmind akkor is megállapíthatja az agresszió cselekményének megtörténtét, ha az nem a határozatban felsorolt elkövetési magatartások szerint valósult meg. Hárs András kiemeli, hogy a Biztonsági Tanács „politikai szerv révén nem feltétlen jogi szempontok szerint dönt, így határozataiban a politikai szükségszerüség és kompromisszum válhat dominánssá", 189 így a BT-t mint politikai döntéshozót nem köti olyan értelemben a legalitás elve sem, ${ }^{190}$ mint egy (büntető) igazságszolgáltatási szervet. Ebből következik, hogy a nyílt végủ felsorolás al-

186 UN Doc. A/RES/3314 (14 December 1974).

187 3314. (XXIX) KGY határozat 3. cikk: „Agressziónak minősül

a) ha egy állam fegyveres erôi inváziót vagy támadást hajtanak végre egy másik állam területe ellen, vagy mindenfajta katonai megszállás, bármilyen ideiglenes is, amely ilyen invázió vagy támadás következménye, vagy egy másik állam területének vagy területrészének erö alkalmazásával történő annektálása;

b) ha egy állam fegyveres erői bombázzák egy másik állam területét, vagy ha egy állam bármiféle fegyvert használ egy másik állam területe ellen;

c) ha egy állam kikötôit vagy partvidékét egy másik állam fegyveres eröi blokád alá veszik;

d) ha egyállam fegyveres eröi megtámadják egy másikállam szárazföldi, tengeri vagy légi eröit, tengeriés légiflottáját;

e) ha egy állam a fegyveres eröit, melyek egy másik állam területén tartózkodnak a fogadó állammal történt megegyezés alapján, az egyezményben foglalt feltételek megszegésével használja fel, vagy ha azok az egyezmény lejárta után tovább tartózkodnak az illetó területen;

f) ha egy állam megengedi egy másik állam számára, hogy területét, amelyet egy másik állam rendelkezésére bocsátott, agressziós cselekmény elkövetésére használják egy másikállam ellen;

g) ha egy állam fegyveres bandákat, csoportokat, önkénteseket vagy zsoldosokat küld - vagy a nevében ilyeneket küldenek - egy másik állam ellen fegyveres cselekmények végrehajtására, melyek olyan súlyosak, hogy kimerítik a fent sorolt cselekményeket, illetve ha egy államnak komoly része van ebben" - szintén Hoffmann Tamás fordítása. Lásd: Hoffmann, 2019, 63. o.

188 Valki, 2014, 728. o.

189 Hárs, 2018, 7. o.

190 Azzal, hogy az ENSZ Alapokmányában foglaltakra, az emberi jogokra, a humanitárius jogra, a nemzetközi szerződésekre és az arányosság elvére nyilvánvalóan tekintettel kell lennie. Lásd: Hárs, 2018, 7. 
kalmazása az ICC esetén nem járható út, ezért a Római Statútumba átemelt lista csak megszorítóan értelmezhetô, és a közgyưlési határozatban szereplő lista mesterséges lezárása válik szükségessé. ${ }^{191}$

A 8bis cikkhez viszonyítva a „15bis cikk” végső szövegváltozatának elfogadása sokkal keményebb diónak bizonyult, egyrészt a kampalai módosításokat nem ratifikáló államok jövőbeni jogállása, másrészt a Biztonsági Tanács az agresszió elkövetésének megállapításában játszott szerepe miatt. ${ }^{192}$ Utóbbi kapcsán elmondható, hogy a Nemzetközi Jogi Bizottság 1994. évi statútumtervezete szerint az ICC agresszió feletti joghatósága a BT erről szóló határozataitól függött volna, ugyanakkor ezt a változatot - az Egyesült Királyság és Franciaország nem meglepő lobbija ellenére - az államok a Biztonsági Tanács múködési hatékonyságának egyértelmú anomáliái és a tagállamok döntéshozatalban való részvételének korlátozottsága miatt rendkívül problémásnak vélték, és többségük úgy tartotta, hogy nem kellene a Római Statútumban a BT-nek exkluzív hatáskört adni az agresszió cselekményének megállapítására, ${ }^{193} \mathrm{~s}$ további kétségeket vetett fel, hogy a BT állandó tagjainak vétójoga esetlegesen örökre megbéníthatja az ICC agresszió feletti joghatóságát mind saját maguk, mind szövetséges államaik felett. ${ }^{194}$

A kizárólagosság mellett főképp a Biztonsági Tanács állandó tagjai próbáltak meg érvelni az ENSZ Alapokmány 39. cikkéből kiindulva, ám végül az az álláspont kerekedett felül, hogy noha a BT felelőssége a nemzetközi béke és biztonság fenntartásában - az ENSZ Alapokmány 24. cikke szerint - elsődleges, nem kizárólagos. ${ }^{195}$ Emellett szólt az az érv is, hogy az ENSZ Közgyưlése szintén számos alkalommal állapította meg agresszió cselekményének megtörténtét, mi több, az Egyesült Államok, az Egyesült Királyság és Franciaország 1950-ben támogatták az ún. Egyesült Erővel a Békéért (Uniting for Peace) elnevezésú közgyưlési határozat ${ }^{196}$ megszületését, amely elismerte az ENSZ plenáris szervének erre vonatkozó hatáskörét. Az exkluzivitás ellen a BT nem állandó tagjai továbbá azt hozták még fel, hogy maga a Nemzetközi Bíróság is több ízben foglalkozott olyan ügyekkel, ahol felmerült az agresszió kérdése, ${ }^{197}$ jóllehet az ICJ óvatosabb volt annál, hogy az „agresszió” kifejezést ténylegesen a döntések szövegébe szője.

191 Clark, 2015, 782. o.

192 Blokker és Kreß, 2010, 889. o.; Trahan, 2011, 49. o.

193 Kreß és von Holtzendorff, 2010, 1194. o.

194 Cassese, 1999, 144. o., 147. o.

195 Clark, 2015, 786. o.

196 UN Doc. A/RES/377 (3 November 1950).

197 Case Concerning Military and Paramilitary Activities in and against Nicaragua (Nicaragua v. the US), Judgment of 27 June 1986, I.C.J. Reports 1986; Legal Consequences of the Construction of a Wall in Palestinian Territory, Advisory Opinion of 9 July 2004, I.C.J. Reports 2004; Case Concerning Armed Activities on the Territory of the Congo (Democratic Republic of Congo v. Uganda), Judgment of 19 December 2005, I.C.J. Reports 2005 . 
Emellett azonban azt - a végül kisebbségben maradt érvet - is látnunk kell, hogy az agresszió büncselekménye és az agresszió cselekménye kéz a kézben járnak abban az értelemben, hogy nem lehet az állam cselekménye miatt elítélni valakit anélkül, hogy közben ne fejeznénk ki rosszallásunkat az állam felett. ${ }^{198}$ Így a Nemzetközi Jogi Bizottság a Római Statútum kodifikációja során azon az állásponton volt, hogy nem volna helyénvaló, ha az ICC az állam által elkövetett agresszió megállapítása hiányában ítélhetne el valakit az agresszió bû́ncselekménye miatt, és utóbbi szerepére az ILC a legalkalmasabbnak a Biztonsági Tanácsot tekintette az ENSZ Alapokmány VII. fejezetével összhangban. ${ }^{199}$

Így az SWGCA egy olyan szövegváltozatot fogalmazott meg, amely nem teszi kizárólagosan egy külső szervtől - legyen az a Biztonsági Tanács, a Közgyuulés vagy akár a Nemzetközi Bíróság - függővé az agresszió cselekményének megállapítását, és nem teszi - az ártatlanság vélelmét tiszteletben tartva - kötelezővé egy külső szerv minősítésének elfogadását az ICC-re nézve - mely utóbbi a Római Statútum 15bis cikk (9) bekezdése, illetve 15ter cikk (4) bekezdése alatt került explicit rögzítésre ${ }^{200}$-, mindazonáltal a Biztonsági Tanács erre vonatkozó hatásköreit is megfelelően érvényre juttatja.

A Kampalában elért kompromisszumos megoldás tehát végül az lett, hogy a „15bis cikket” kettéválasztották 15bis és 15ter cikkekre, amelyek az eljárást indító mechanizmusok szerint kategorizálva szabályozzák az agresszió miatti eljárás megindításának menetét, előbbi a részes államok utalására és az ICC föügyészének proprio motu eljáráskezdeményezésére, utóbbi a Biztonsági Tanács által az ICC elé vitt helyzetekre alkalmazandó, a népirtás, illetve az emberiesség elleni és háborús bűncselekmények gyanúja miatt indított eljárásokhoz viszonyítva mintegy lex specialisként.

\subsection{Az agresszió büncselekményével kapcsolatos eljárásjogi kérdések}

A 15bis cikk (1) bekezdése alapvetésként rögzíti, hogy az ICC joghatóságot gyakorolhat az agresszió bủncselekménye felett olyan esetekben, amikor a 13. cikk a) pontja alapján valamely részes állam vagy a 13. cikk c) pontja alapján a föügyész indítja meg az eljárást. Ezzel párhuzamosan a 15ter cikk (1) bekezdése is hasonlóan rendelkezik a Római Statútum 13. cikk b) pont vonatkozásában, amikor is a Biztonsági Tanács terjeszt egy helyzetet a bíróság elé, mely utóbbi esetén az eljárás megindításának nem feltétele, hogy a BT elózetesen megállapítsa az agresszió cselekményének megtörténtét. ${ }^{201}$

198 Crawford, 1994, 147. o.

199 Crawford, 1995, 411. o.

200 Római Statútum 15bis cikk (9) bekezdés és 15ter cikk (4) bekezdés: „Az agresszió cselekményének meghatározása a Bíróságon kívüli szerv által a Bíróságnak e Statútum alapján tett megállapításait nem érinti.”

201 Kreß és von Holtzendorff, 2010, 1211. 0. 
A két szakasz (2) és (3) bekezdése szó szerint ugyanaz, melyek további feltételeket túznek a tényleges joghatóság-gyakorláshoz. A 15bis cikk és a 15ter cikk (2) bekezdése akként rendelkezik, hogy „a Bíróság csak akkor gyakorolhat joghatóságot az agresszió büncselekménye felett, ha azokat jelen módositások harminc Részes âllam általi megerôsitése vagy elfogadása után egy évvel követték el”, továbbá a (3) bekezdés kimondja, hogy „a Bíróság jelen cikk szerint joghatóságot gyakorol az agresszió felett, feltéve, hogy a Részes Államok erről 2017. január 1-je után döntést hoznak ugyanolyan többséggel, amely a jelen Statútum módositásának elfogadásához szükséges" [ez a gyakorlatban a 121. cikk (3) bekezdésével ${ }^{202}$ összhangban a részes felek kétharmadát jelentette, azaz 123 államból 82 államot]. S bár a kampali módosítások 2016. június 26-án elérték a 15bis cikk (2) bekezdésében és a 15ter cikk (2) bekezdésében előírt 30 ratifikációt, ez a 15bis cikk (3) bekezdése és a 15ter cikk (3) bekezdése szerint nem jelentette egyben azt, hogy az ICC 2017. június 26-tól automatikusan joghatóságot gyakorol az agresszió felett. A Részes Államok Közgyưlése a joghatóság tényleges „aktiválását” csak 2017. december 14-én szavazta meg - a jelenlévők konszenzusával -, ${ }^{203}$ a kampalai módosítások hatálybalépésének időpontját az azokat megerősítő, illetőleg elfogadó államokra ${ }^{204}$ nézve 2018. július 17-re túzve ki. E helyütt fontos rávilágítani, hogy az agresszió feletti joghatóság „aktiválásáról” szóló szavazáson való részvételnek nem volt feltétele a kampalai módosítások ratifikációja, ami egyenesen következik abból, hogy előbbihez a részes államok kétharmada szükségeltetett, utóbbihoz pedig elegendőnek bizonyult 30 állam ratifikációja. A 15ter cikk (2) bekezdésével kapcsolatban Roger S. Clark kiemeli, hogy a 30 ratifikáció követelménye csupán eljárási szempontból jelentett korlátozást a Biztonsági Tanácsra nézve, és mivel az abban foglaltak már teljesültek, a BT nemcsak a módosításokat elfogadó államokkal szemben, hanem bármely állammal szemben - így értelemszerúen a Római Statútumban nem részes államokkal szemben is - eljárást indíthat agresszió miatt a Nemzetközi Büntetőbíróság előtt. ${ }^{205}$

A két passzus „közös rendelkezéseinek” sora ezzel megszakad. A 15bis cikk (4) bekezdése csak a 13. cikk a) pont és 13. cikk c) pont szerinti eljárásokra alkalmazandó ún. „opt-out” klauzulát tartalmaz, amely úgy szól, hogy „a Bíróság a 12. cikkel összhangban joghatóságot gyakorolhat valamely Részes Állam agresszió cselekményéből fakadó agresszió büncselekménye felett, hacsak e Részes Állam a Bíróság Hivatalvezetőjéhez korábban benyújtott nyilatkoza-

202 Római Statútum 121. cikk (3) bekezdés: „3. A Részes Államok Közgyúlésének ülésén vagy a Felülvizsgálati Konferencián a módositás elfogadásához, ha nem sikerül konszenzust elérni, a Részes Államok kétharmados szavazattöbbsége szükséges."

203 Rome Statute ASP Resolution ICC-ASP/16/Res.5, 14 December 2017.

204 A kampalai módosításokat megerősítő, illetve elfogadó államok száma jelen sorok írásakor 39, a listát lásd: https://asp.icc-cpi.int/en_menus/asp/crime\%200f\%20aggression/pages/default.aspx [Letöltve: 2021. 04. 22.].

205 Clark, 2015, 788. o. 
tában nem jelentette ki, hogy nem fogadja el a Biróság joghatóságát az agresszió büncselekménye felett. Az ilyen nyilatkozatot bármikor vissza lehet vonni azzal, hogy a Részes Állam a nyilatkozattételtól számított három évig meggondolhatja magát." A módosításokat el nem fogadó, illetve nem ratifikáló részes államok jogállása az SWGCA többéves munkája során a tárgyalások hosszan sajgó Achilles-sarka volt. Megoldási javaslatként kezdetben felmerült, hogy a 12. cikk (1) bekezdése ${ }^{206}$ értelmében a kiegészítések ezen részes államokat is kötelezzék, hacsak az „opt-out” lehetőségét nem választják, ${ }^{207}$ míg mások a 121. cikk (5) bekezdésére ${ }^{208}$ hivatkozva az alávetés expressis verbis kinyilatkoztatása mellett érveltek, tekintet nélkül a ratifikációra. ${ }^{209}$

Kampalában végül e második álláspont képviselői kerekedtek felül, sajátos „opt-out”10 eljárást kodifikálva. Minthogy a Római Statútumhoz annak 120. cikke ${ }^{211}$ szerint fenntartásokat fúzni nem lehet, azok a részes államok, amelyek a módosításokat nem fogadták el kötelezőnek magukra nézve, az ICC Hivatalához benyújtott nyilatkozatukkal felmentést kérhettek az agresszió feletti joghatóság-gyakorlás alól. Azt azonban - esetjog hiányában - azóta sem sikerült tisztázni, hogy mi a helyzet azokkal az államokkal, amelyek a kampalai módosításokat nem ratifikálták, egyszersmind az imént említett „opt-out” lehetőségével sem éltek.

A 15bis cikk (4) bekezdésével kapcsolatban értelmezési kérdéseket vet fel, hogy a „valamely Részes Állam által elkövetett agresszióból fakadó agresszió büncselekménye" formulát általában véve a Római Statútumban részes államok agressziójára nézve, vagy csupán a kampalai módosításokat elfogadó, illetve ratifikáló részes államok agressziójára nézve kell-e vonatkoztatni. Szimplán a normaszöveg alapján azt mondhatjuk, hogy nyelvtani értelemben nem kell a kiegészítéseket elfogadó részes államokra szorítkoznunk, mindazonáltal utóbbinak ellentmondanak a Római Statútum 121. cikk (5) bekezdésében foglaltak: „[...] a módositáshoz hozzá nem járuló Részes Állam tekintetében a Bíróság nem gyakorolhatja joghatóságát a módositással érintett büntett tekintetében, ha azt az adott Részes Állam állampolgárai, vagy annak területén követték el”.

206 Római Statútum 12. cikk (1) bekezdés: „Az az Állam, amelyik a jelen Statútum Részesévé válik, egyúttal elfogadja a Bíróság joghatóságát az 5 . cikkben írt büntettek tekintetében."

207 Kreß és von Holtzendorff, 2010, 1213. o.; McDougall, 2013, 258-259. o.

208 Római Statútum 121. cikk (5) bekezdés: „A jelen Statútum 5, 6, 7. és 8. cikkének módositása a módosítást elfogadó Részes Államokra nézve egy évvel a megerősitő vagy elfogadó okirat letétbehelyezése után lép hatályba. A módositáshoz hozzá nem járuló Részes Állam tekintetében a Bíróság nem gyakorolhatja joghatóságát a módositással érintett büntett tekintetében, ha azt az adott Részes Állam állampolgárai, vagy annak területén követték el."

209 Van Schaack, 2010-2011, 598. o.

$210 \mathrm{Az}$ „opt-out”-modell alkalmazása sokkal nagyobb valószínúséggel vezet ahhoz, hogy az utólagos módosítások több államot kössenek, mint az „opt-in”-modell alkalmazása. Lásd erről bővebben: Galbraith, 2013, 309. o.

211 Római Statútum 120. cikk: „A jelen Statútumhoz nem lehet fenntartásokat tenni.” 
A 15bis cikk (4) bekezdésének nemcsak a 121. cikk (5) bekezdésével, hanem a 12. cikkel való viszonya is számos értelmezési kérdést hordoz magában. A többségi szakirodalom egyetért abban, hogy az ICC joghatósága fennáll akkor, ha mind az agresszor, mind az áldozat a Római Statútum részes állama és ratifikálta a kampalai módosításokat, ellenben nem nyújtott be mentesítési nyilatkozatot a bíróság Hivatalához. Abban is egyetértés mutatkozik, hogy az ICC joghatósága nem áll fenn akkor, ha az agresszor részes állam, egyszersmind élt az „opt-out” lehetőségével. ${ }^{212}$

A tekintetben is széles körú doktrinális összhangot láthatunk, hogyha az agresszor olyan részes állam, amelyik nem ratifikálta a 2010-ben elfogadott kiegészítéseket, és mentesítési nyilatkozatot sem nyújtott be, ám az áldozat ratifikálta a 2010-ben elfogadott kiegészítéseket, a bíróságnak a Római Statútum 12. cikk (2) bekezdés a) pontja alapján fennáll a joghatósága, függetlenül attól, hogy az áldozat korábban élt-e a mentesítés lehetőségével vagy sem. ${ }^{213}$ Marko Milanović azonban felhívja rá a figyelmet, hogy e helyütt felmerül a megszorító értelmezés lehetősége is, melynek fényében a bíróság joghatósága azért nem áll fenn, mert az agresszor nem fogadta el expressis verbis a kiegészítéseket a Római Statútum 121. cikk (5) bekezdése alapján. ${ }^{214}$

Azokban a helyzetekben, ahol az agresszor részes állam nem ratifikálta a kampalai módosításokat, és nem is tett „opt-out” nyilatkozatot, ugyanakkor az áldozat sem ratifikálta a 2010-ben elfogadott kiegészítéseket, az ICC nem bír joghatósággal az agresszió felett, függetlenül attól, hogy utóbbi élt-e a mentesítéssel vagy sem. ${ }^{215}$ Ez esetben a bíróságnak - elméletileg - akkor lehetne joghatósága, ha az a részes állam, amelyik nem ratifikálta a kampalai módosításokat, a Római Statútum 12. cikk (3) bekezdése ${ }^{216}$ alapján eseti alávetési nyilatkozatot tenne, jóllehet ennek a forgatókönyvnek a gyakorlati megvalósulására igencsak csekély esély mutatkozik. ${ }^{217}$

További bizonytalanságok övezik azt a szcenáriót, amikor az agresszor részes állam nem ratifikálta a kampalai módosításokat, és nem tett mentesítési nyilatkozatot, az áldozat pedig olyan részes állam, amelyik ratifikálta a 2010-ben elfogadott kiegészítéseket. Ezzel kapcsolatban kétféle értelmezés él a nemzetközi jogi szakirodalomban. Az első a „kiterjesztő” vagy „megengedő" nézet, miszerint az ICC joghatósága a 12. cikk (2) bekezdés a) pontja alapján

212 Heller, 2010 [Online]; McDougall, 2013, 261. o.; Reisinger Coracini, 2010, 782. o.; Milanović, 2012, 182. o.

213 McDougall, 2013, 261. o.; Reisinger Coracini, 2010, 782. o.; Milanović, 2012, 182. o.

214 Milanović, 2012, 182. o.

215 McDougall, 2013, 261. o.; Reisinger Coracini, 2010, 782. o.; Milanović, 2012, 182. o.

216 Római Statútum 12. cikk (3) bekezdés: „Ha Bíróság joghatóságának olyan Állam általi elfogadása szükséges a 2. bekezdés szerinti célból, amely a jelen Statútumban nem Részes Állam, az adott Állam a hivatalvezetöhöz benyújtott nyilatkozattal elfogadhatja az adott büncselekmény tekintetében a Bíróság joghatóságát. Az elfogadó Állam késedelem és kivétel nélkül a IX. Fejezetben meghatározottak szerint együttmüködik a Bírósággal."

217 McDougall, 2013, 261. o.; Reisinger Coracini, 2010, 782. o.; Kreß és von Holtzendorff, 2010, 1214. o. 
fennáll, tekintet nélkül arra, hogy az áldozat élt-e az „opt-out” lehetőségével vagy sem. ${ }^{218}$ A második a „megszorító” vagy „szigorító” nézet, melynek képviselői a statútum 121. cikk (5) bekezdése szerint azzal érvelnek, hogy a bíróságnak nem lehet joghatósága azért, mert az agresszor nem ratifikálta az utólagos kiegészítéseket. ${ }^{219}$

A fentihez hasonlóan válaszolható meg az a kérdés, hogy fennáll-e az ICC joghatósága akkor, ha az agresszor részes állam ratifikálta a módosításokat, mentesítési nyilatkozatot sem tett, de az áldozat részes állam nem ratifikált? A „kiterjesztô” értelmezés képviselői itt is a 12. cikk (2) bekezdés a) pontjára hivatkozva azt mondják, hogy az ICC-nek van joghatósága, míg a „megszorító” értelmezést támogatók a 121. cikk (5) bekezdéséből azt vezetik le, hogy az agresszió feletti joghatóság-gyakorláshoz mind az agresszornak, mind az áldozatnak ratifikálni kellene a kampalai módosításokat.220

A Római Statútum soron következő rendelkezése szintén csak a részes államok, valamint a föügyész által indított helyzetekre alkalmazandó szignifikáns korlátozást állapít meg, azaz a Biztonsági Tanácsot e passzusban rögzítettek újfent nem kötik. A 15bis cikk (5) bekezdése kimondja, hogy „azon államokkal szemben, amelyek e Statútumnak nem Részes Államai, a Bíróság nem gyakorolja joghatóságát az agresszió büncselekménye felett akkor, ha e büncselekményt nem Részes Állam állampolgára követte el, vagy nem Részes Állam területén követték el". Noha felbukkant olyan álláspont, mely szerint a 12. cikk (2) bekezdése értelmében az ICC-nek akkor is fennáll az agresszió feletti joghatósága, ha az áldozat nem részes állam, a többségi szakirodalmi narratíva ennek ellenkezője mellett érvel. ${ }^{221}$ Annyi bizonyos, hogy nem áll fenn a joghatóság akkor, ha az agresszor részes állam nem ratifikálta a kampalai módosításokat, és az áldozat a Római Statútumnak nem részes állama. Ugyanez áll arra az esetre, ha az agresszor részes állam élt az „opt-out” lehetőségével, és ez esetben mindegy is, hogy korábban ratifikálta-e a 2010-ben elfogadott kiegészítéseket. Szintén egyértelmű, hogy a bíróság nem gyakorolhat joghatóságot az agresszió felett akkor, ha az agresszor állam nem részes fél a Római Statútumban. Az a kérdés pedig továbbra is nyitva marad, hogy vajon el lehet-e fogadni az ICC agresszió feletti joghatóságát ad hoc, a Római Statútum 12. cikk (3) bekezdése alapján. 222

Tovább haladva, a 15bis cikk (6), (7) és (8) bekezdéseiben lényeges rendelkezéseket találhatunk a Biztonsági Tanácshoz kapcsolódóan. A 15bis cikk (6) bekezdése rögzíti, hogy „ha a Fö̈̈gyész arra a következtetésre jut, hogy az agresszió büncselekménye kivizsgálásának

\footnotetext{
218 McDougall, 2013, 261. o.; Reisinger Coracini, 2010, 782. o.; Milanović, 2012, 182. o.

219 Akande, 2011, 27. 0.

220 Akande, 2011, 27. o.; Milanović, 2012, 182. o.

221 Heller, 2010 [Online]; McDougall, 2013, 261. o.; Reisinger Coracini, 2010, 782. o.; Milanović, 2012, 182. o.

222 Akande és Tzanakopoulos, 2018, 954. o.; Stahn, 2010, 880. o.; McDougall, 2013, 264. o.; Reisinger Coracini, 2010, 781. o.; Kreß és von Holtzendorff, 2010, 1214. o.
} 
fennáll az észszerü alapja, akkor először meg kell vizsgálnia, hogy a Biztonsági Tanács megállapította-e az agresszió cselekményének elkövetését az érintett állam vonatkozásában. A Föügyész értesíti az Egyesült Nemzetek Fôtitkárát a Bíróság előtti helyzetról, ideértve valamennyi releváns információt és dokumentációt." Tehát a 15bis cikk (6) bekezdése nemcsak az ICC föügyésze által a Római Statútum 13. cikk c) pontja és 15. cikke alapján indult eljárásokra vonatkozik, hanem valamennyi részes állami utalással és proprio motu kezdeményezéssel indult eljárásra, azok közvetlenül a nyomozás megindítása előtti szakaszára. Az agresszió cselekménye elkövetésének megállapítása evidens azokban az esetekben, amikor a BT határozatában szó szerint az „agresszió cselekménye” kifejezést használja, ám az „erőszak” terminológiáját az ENSZ Alapokmányában Hoffmann Tamás szavaival élve "fogalmi káosz és tartalmi homály"223 övezi, ezért is gyakoribbak azok az esetek, amikor a Biztonsági Tanács határozataiban az agresszió cselekménye helyett az „agresszív állam” („a State being aggressive”) vagy az „agresszív viselkedés” („aggressive behaviour”) kifejezések szerepelnek. Az sem egyértelmú, hogy az agresszió cselekménye megállapításának a BT-határozat rendelkező részébe kell-e kerülnie, vagy elegendő, ha e határozat preambulumában az ENSZ főszerve az „agresszív állam” vagy az „agresszív viselkedés” miatt aggodalmát fejezi ki. A főtitkár értesítése előfeltétele a nyomozás megkezdésének, azokban az esetekben pedig, amikor a BT az agresszió cselekményének elkövetését nem állapította meg, a hat hónapos várakozási idő az értesítés napjától kezdődik.

A Római Statútum soron következő rendelkezései két alternatívát vázolnak fel: az első, hogy a BT az agresszió cselekményét megállapította, míg a második, hogy a fôtitkár értesítésétől számított hat hónapon belül erre nem került sor. A 15bis cikk (7) bekezdése alapján tehát a föügyésznek nincs további engedélyre szüksége a nyomozás megindításához akkor, ha az agresszió cselekményét a BT konstatálta, hacsak - a 15bis cikk (10) bekezdése ${ }^{224}$ szerint az agresszió mellett népirtás, emberiesség elleni vagy háborús bűncselekmények elkövetésének alapos gyanúja nem merül fel, tudniillik utóbbi esetén lehetséges olyan eset, hogy a tárgyalás-előkészítő tanácsnak külön engedélyeznie kell a nyomozás megindítását [így például a 15. cikk (3) bekezdése alapján, proprio motu eljárások esetén].

A 15bis cikk (8) bekezdése ezzel szemben akként rendelkezik, hogy „ha az értesitéstöl számitott hat hónapon belül nem hoznak ilyen döntést, a Fö̈̈gyész folytathatja a nyomozást az agresszió büncselekménye vonatkozásában, feltéve, hogy a 15. cikk alapján a tárgyalás-előkészitó kollégium engedélyezte a nyomozás megindítását az agresszió büncselekménye vonatkozásában, és

223 Hoffmann, 2019, 47. o.

224 Római Statútum 15bis (10) bekezdés és $15 t e r$ cikk (5) bekezdés: „E cikk nem érinti a joghatóság gyakorlására vonatkozó feltételeket az 5. cikkben található egyéb büncselekmények tekintetében." Tehát e rendelkezés a részes államok által, a Biztonsági Tanács által és a föügyész által indított eljárásokra is vonatkozik. 
a Biztonsági Tanács a 16. cikk alapján másképp nem határozott”. Tehát az agresszió cselekményének megállapítását tartalmazó BT-határozat hiányában a nyomozás megindítása mindenképp engedélyhez kötött, akkor is, ha azt valamely részes állam kezdeményezte - s ez utóbbit el kell határolnunk a fentebb ismertetett 15bis cikk (10) bekezdése szerinti esettől -, amikor is a kompetens bírói tanács az ICC tárgyalás-elókészítő kollégiuma, amelynek a 39. cikk (1) bekezdése ${ }^{225}$ szerint legalább hat bíróból kell állnia. Továbbá a 15bis cikk (8) bekezdésével az is nyilvánvalóvá vált, hogy a Biztonsági Tanács a Római Statútum 16. cikkében ${ }^{226}$ megállapított eljárást felfüggesztő hatásköre az „agressziós eljárásokra” éppúgy alkalmazható, mint a népirtás, illetve az emberiesség elleni és a háborús bủntettek esetén, azaz a BT 12 hónapra felfüggesztheti a nyomozást, illetve a büntetőeljárást az ENSZ Alapokmány VII. fejezete alapján.

Végül ismét elérkeztünk az elemzés során a már korábban említett, Kampalában sokat vitatott 15bis (9) és 15ter (4) cikkekhez, melyek kulcsfontosságúak mind az ICC autonómiája és büntetőbírósági funkciója, mind a tisztességes eljáráshoz való jog és az ártatlanság vélelme miatt. Emlékeztetőül érdemes felvillantani, hogy e két cikk leszögezi: „Az agresszió cselekményének meghatározása a Bíróságon kivuüli szerv által a Bíróságnak e Statútum alapján tett megállapitásait nem érinti." Az ICC tehát szabadon mérlegelhet: BT-határozat hiányában is megállapíthatja az agresszió cselekményének elkövetését, vagy dönthet úgy, hogy akkor sem történt agresszió, ha azt korábban a Biztonsági Tanács vagy akár a Nemzetközi Bíróság megállapította.

A fentieket összegezve talán nem túlzás azt állítani, hogy az ICC agresszió bûncselekménye feletti eljárási képessége sui generis joghatósági rendszert képez egy sui generis joghatósági rendszerben - kiváltképpen a részes államok és a föügyész által indított eljárásokban -, amit a bíróság időbeli, személyi és területi joghatóságára vonatkozó kü-

225 Római Statútum 39. cikk (1) bekezdés: „A birák megválasztása után amint lehetséges, a Bíróság a 34. cikk (b) pontja szerinti Kollégiumokba szerveződik. A Fellebbviteli Kollégium az elnökböl és négy biróból áll, az Elsőfokú Kollégiumot és a Tárgyalás-elókészitő Kollégiumot pedig egyenként legalább hat biró alkotja. A birák tanácsokba osztásának alapjául az egyes Kollégiumok feladatának jellege, valamint a Bíróságba választott bírák képesítése és tapasztalatai szolgálnak, úgy, hogy minden Kollégium megfelelő arányban tartalmazzon büntető anyagi és eljárásjogi, valamint nemzetközi jogi szaktudású bírót. Az Elsőfokú Kollégium és a Tárgyalás-előkészitô Kollégium föleg büntetôbírósági tárgyalási tapasztalattal rendelkezó birákból áll."

226 A Római Statútum e cikkének elemzésére az értekezés később egy külön fejezetet szentel A Nemzetközi Büntetôbíróság előtti nyomozás vagy büntetőeljárás felfüggesztése a Római Statútum 16. cikke alapján címmel, így a rendelkezés részletes elemzését lásd ott. 
lönbségek, valamint az eljárás megindításának előfeltételeire vonatkozó többletfeltételek eredményeznek.

Elsőként (i) idevehetjük az időbeli joghatóságra vonatkozó különbséget, melynek eredményeképpen a bíróság az agresszió búncselekménye felett csak 2018. július 17. óta gyakorol effektíve joghatóságot, míg ez az időpont a népirtás, az emberiesség elleni és a háborús deliktumok esetén 2002. július 1-jéig nyúlik vissza. Másodikként (ii) felhozható a személyi hatály leszúküulése, minthogy - ismét sorra nem véve a nem ratifikáló (vagy ratifikáló), illetve mentesítést nem kérő (vagy kérő) részes államokkal szembeni eljárási képességre vonatkozó lehetséges szcenáriókat - a kampalai módosításokat jelen sorok írásáig csupán 39 állam ratifikálta, holott a Római Statútum 123 részes féllel rendelkezik. Harmadikként (iii) a területi elven alapuló joghatóságot is korlátozás éri az „agressziós eljárásokban” a többi nemzetközi búncselekményhez képest, amikor a 15bis cikk (5) bekezdése úgy rendelkezik, hogy nem részes államok területén (részes állam állampolgára által) elkövetett deliktumok felett az ICC-nek nincs joghatósága. Ugyanezen rendelkezés a statútum személyi hatályát szintén szúkíti az agresszió tekintetében, minthogy nem részes államok állampolgárai által (részes államok területén) elkövetett agresszió esetén sem gyakorolhat a bíróság joghatóságot. S mint ahogyan azt láthattuk, a nyilvánvaló joghatóságbeli eltéréseken túl egyéb sajátos többletfeltételek is figyelembe veendők (például a módosítások külön ratifikációja vagy az „opt-out” nyilatkozat) az „agressziós eljárások” megindítása során.

Az azonban okvetlenül megjegyzendő, hogy e suigenerisjoghatósági rendszer a Biztonsági Tanács által ICC elé vitt helyzetekben kevésbé sajátságos a másik két eljárást indító mechanizmushoz képest, minthogy a BT-t a joghatósági korlátok közül egyedül az aktiváláshoz szükséges 30 ratifikáció és a visszamenő hatály tilalma kötötte, illetőleg köti. A Biztonsági Tanács hatáskörei a Római Statútum „rezsimjét” ismételten „megdöntik”, azaz a szerződéses normák meghajolnak a nemzetközi béke és biztonság imperatívusza előtt. Az ICC agresszió feletti joghatóságáról azt mondhatjuk, hogy az némiképp egyszerübbnek túnik - legalábbis az absztrakció és a jogi normák szintjén - a BT indította eljárásokban, mint a részes államok utalásai és a proprio motu búnvádi eljárások viszonylatában. Ám ezzel párhuzamosan azt sem szabad szem elől tévesztenünk, hogy jóllehet a normatív keretek adottak, sok praktikus kérdés továbbra is homályba vész, amelyek megválaszolása okvetlenül bírói joggyakorlatért „kiált". Az arra vonatkozó jóslatokba bocsátkozás, hogy fog-e indulni az ICC előtt „agreszsziós eljárás", s ha igen, vajon ez belátható időn belül megtörténhet-e, nem hálás feladata a nemzetközi jogászoknak, ugyanakkor a büncselekmény rendkívüli politikai érzékenysége, az erőszakot és az agressziót körülvevő fogalmi bizonytalanságok, valamint a joghatósági korlátok mellett - a jövőbe látás képességét nélkülözve is - határozottan az mondható, hogy az erre mutatkozó esély igencsak kevés. 


\section{A Nemzetközi Büntetőbíróság előtti nyomozás vagy büntetőeljárás felfüggesztése a Római Statútum 16. cikke alapján}

\subsection{A nyomozás vagy büntetőeljárás felfüggesztésének feltételei}

A bíróság előtti büntetőeljárások felfüggesztésének lehetőségéről („deferral”) a Római Statútum 16. cikke rendelkezik, ${ }^{227}$ mely kimondja, hogy „a jelen Statútum szerint, miután a Biztonsági Tanács az Egyesült Nemzetek Alapokmánya VII. fejezetének értelmében hozott határozatában erre kéri a Bíróságot, 12 hónapig nem indítható vagy folytatható nyomozás vagy büntetôeljárás; a kérelmet a Biztonsági Tanács ugyanazon feltételekkel megújithatja". ${ }^{28}$

A norma nyelvtani értelmezése során két észrevételt kell tenni: (i) a nyomozás vagy büntetőeljárás felfüggesztése során a Biztonsági Tanácsnak az ENSZ Alapokmány VII. fejezete alapján kell eljárnia; és (ii) ha a nyomozást vagy büntetőeljárást a BT felfüggesztette, ezen időtartam alatt a bíróság előtt nem lehet eljárást kezdeményezni vagy az eljárást tovább folytatni. A felfüggesztés időtartama legfeljebb 12 hónap lehet, ám a felfüggesztés ugyanezen feltételek mellett megújítható. A Római Statútum nem határozza meg, hogy hány alkalommal lehet a büntetőeljárást felfüggeszteni, ami arra enged következtetni, hogy a megújítások száma - legalábbis elméleti síkon - akár a végtelenbe is futhat. ${ }^{229}$

A statútum arra vonatkozó korlátot sem tartalmaz, hogy csak a BT által előterjesztett helyzetekből adódó vagy bármilyen eljárást fel lehet függeszteni, amiből az következik - és az alább tárgyalt gyakorlat is ezt támasztja alá -, hogy az eljárást indító mechanizmus (részes állam, BT vagy föügyész) irreleváns a 16. cikk alkalmazhatósága szempontjából.

Azon feltétel, miszerint a felfüggesztő határozat „az Egyesült Nemzetek Alapokmánya VII. fejezetének értelmében hozott" kell hogy legyen, azt jelenti, hogy a Biztonsági Tanács nem járhat el az Alapokmány 39. cikkében foglalt követelmények megvalósulásának hiányában, azaz a normára a béke veszélyeztetésére vagy megszegésére, illetve támadó cselekmény - akár agresszió cselekményének - elkövetésére esetén lehet hivatkozni.

A 39. cikkben foglalt feltételek figyelembevétele további kérdéseket von maga után. Az első, hogy ha a BT az Alapokmány VII. fejezete alapján határoz, akkor az ICC vizsgálhatja-e ennek jogszerűségét, az ebben foglalt feltételek fennállását? A második pedig, hogy ki

227 A rendelkezés Római Statútumba foglalásának egyéb lehetséges céljairól lásd: Kirs, 2009, 145-154. o.

228 Csapó, 2012, 42 . 0.

229 El Zeidy, 2002, 1516. o. 
határozza meg, hogy mit jelent a béke veszélyeztetése? Meghatározhatja-e az az állam vagy az a személy a béke veszélyeztetését, aki a büntetőeljárás felfüggesztéséból előnyökhöz jut? Mondhatná-e azt al-Bashír, hogy ő maga jelenti a veszélyt a nemzetközi békére és biztonságra, ezért saját eljárásának felfüggesztését kéri a BT által? A fenti kérdésekre sem a Római Statútum, sem az ENSZ Alapokmánya nem ad választ. ${ }^{230}$

A rendelkezés további fordulata, miszerint „nem indítható vagy folytatható nyomozás vagy büntetőeljárás", szintén kérdésfeltevést eredményez: a nyomozásnak, illetve büntetőeljárásnak konkrétnak kell lennie, vagy preemtív, pro futoro jellegú is lehet? A 16. cikk nyelvezetéből nem olvasható ki a válasz, mindazonáltal a Human Rights Watch ${ }^{231}$ és Robert Cryer $^{232}$ amellett érvelnek, hogy a felfüggesztés nem lehet absztrakt, hanem annak egy konkrét, bíróság elé terjesztett helyzet vonatkozásában kell történnie, melynek végét - Csapó Zsuzsannával egyetértve - a vádemelés jelenti. ${ }^{233}$ Onnantól kezdve tehát, hogy az eljárás a tárgyalási szakaszba lép, azaz a Föügyészi Hivatal vádat emelt és a tárgyalás-előkészítő tanács a vádindítványt megerősítette, a 16. cikk hatályát veszti az adott ügy viszonylatában.

A 16. cikk elfogadásának pillanatától kezdve heves vitákat gerjesztett. Egyes nézetek ${ }^{234}$ szerint e norma megkönnyíti a tartós megbékélést és az átmeneti igazságszolgáltatás által felkínált mechanizmusok alkalmazását, míg mások ${ }^{235}$ szerint a büntetlenség kultúráját szolgálja az elhúzódó béketárgyalásokkal. Szintén mások szerint a 16. cikk a nemzetközi közösség garanciája a kivételes biztonsági kockázatok kezelésére (például a béke veszélyeztetése, megsértése vagy agresszió elkövetése esetén). Ez utóbbival egyetértő államok a rendelkezés ilyen formában történő statútumba foglalását ellenezték, az ICC bírói függetlenségét és a terheltek tisztességes eljáráshoz való jogát féltve, ám végül szemet hunytak az aggályok felett azzal, hogy „az esetrőlesetre történő mérlegelésből adódófelelősség a Biztonsági Tanácsot terheli". ${ }^{236}$

E cikk a nemzetközi béke és biztonság fenntartása, valamint a nemzetközi büntetőjogi felelősségre vonás között feszülő esetleges érdekkonfliktusok feloldására szolgál, egyben a BT kezébe adott legerősebb eszköz az ICC előtti eljárások közvetlen befolyásolására. ${ }^{237}$

230 El Zeidy, 2002, 1519-1523. o.

231 Human Rights Watch: The ICC and the Security Council: Resolution 1422, Legal and Policy Analysis, elérhető: https://www.hrw.org/legacy/campaigns/icc/dics/1422legal.htm [Letöltve: 2019. 11. 30.].

232 Cryer, 2006, 222. 0.

233 Csapó, 2012, 42 . o.

234 Cryer et al., 2016, 170. o.

235 Report of the UN Secretary General, The Rule of Law and Transitional Justice in Conflict and Post-Conflict Societies, UN Doc. S/2004/616 (3 August 2004), \$64.

236 Verduzco, 2015, 57. o.

237 Bergsmo és Perić, 2008, 598. o. 
Eredetileg a Nemzetközi Jogi Bizottság '94-es Római Statútum-tervezetében ${ }^{238}$ a Biztonsági Tanács filterfunkciót töltött volna be a bíróság előtti eljárások megindításában. ${ }^{239}$ Az eljárás felfüggesztéséről szóló 16. cikket egyfajta kompromisszumos megoldásként iktatták be a Római Statútum normái közé, az ICC politikai függetlensége és a BT nemzetközi béke és biztonság fenntartásában kapott mandátuma közötti egyensúly megteremtése érdekében. ${ }^{240}$

A 16. cikkre a Dárfúr- és a Líbia-határozatok bevezető rendelkezéseiben is található utalás, miszerint: „A Biztonsági Tanács figyelembe veszi, hogy a Római Statútum 16. cikke alapján a Nemzetközi Büntetöbiróság nem kezdeményezhet, illetve folytathat nyomozást vagy büntetöeljárást 12 hónapig, amennyiben a Biztonsági Tanács erre felszólitja."

\subsection{Az eljárás felfüggesztése a gyakorlatban}

Jelen sorok írásáig a BT egyszer élt a nyomozás vagy büntetőeljárás felfüggesztésével kapcsolatos hatáskörével, amikor is a Római Statútum hatálybalépésével egyidejûleg hozott határozatával az ENSZ-békefenntartók ICC elôtti felelősségre vonásának vette elejét, majd ugyanezen határozat érdemi rendelkezéseit egy évvel később egy másik határozatban megújította.

A Biztonsági Tanács 2002-ben fogadta el 1422. számú határozatát, ${ }^{241}$ majd pedig 2003-ban az 1487. számút, ${ }^{242}$ melyek célja az volt, hogy a 16. cikk alapján az ICC előtti eljárások indítását meggátolják a Római Statútumban nem részes államok állampolgáraival szemben. ${ }^{24} \mathrm{~A}$ határozatok elfogadása az Amerikai Egyesült Államok politikai nyomásgyakorlásának volt köszönhető, aki azzal fenyegetőzött, hogy visszavonja a Bosznia-Hercegovina-i békefenntartó múveletekhez (United Nations Peacekeeping Mission in Bos-

238 A Nemzetközi Jogi Bizottság 1994. évi statútumtervezete, 26-74. o.

239 1994. évi Római Statútum-tervezet 23. cikk (3) bekezdés: „E Statútum rendelkezései alapján nem lehet büntetöeljárást inditani olyan, a nemzetközi békétés biztonságot veszélyeztetô vagy sértő helyzetekben, valamint agresszió elkövetése esetén, melyekkel az Egyesült Nemzetek Alapokmányának VII. fejezete alapján a Biztonsági Tanács foglalkozik addig, amig a Biztonsági Tanács másképp nem határoz", elérhető: https:/legal.un.org/ilc/texts/instruments/english/ commentaries/7_4_1994.pdf [Letöltve: 2019. 11. 20.].

240 Kirsch és Holmes, 1999, 8. o.

241 UN Doc. S/RES/1422 (12 July 2002).

242 UN Doc. S/RES/ 1487 (12 June 2003).

243 1422. (2002) BT-határozat 1. cikk: „A Biztonsági Tanács az Egyesült Nemzetek Alapokmányának VII. fejezete és a Római Statútum 16. cikke alapján felszólítja a Nemzetközi Büntetőbiróságot, hogy amennyiben olyan ügy kerül elé, amelynek a Római Statútumban nem részes, ugyanakkor az Egyesült Nemzetek által indított vagy engedélyezett békefenntartó müveletekben részt vevő állam állampolgára - e müveletekben jelenleg vagy korábban békefenntartóként szolgáló személy - az érintettje, 2002. július 1-jétól számított 12 hónapig függessze fel az ilyen eljárást vagy annak megindítását, kivéve, ha a Biztonsági Tanács másképp nem rendelkezik." Az 1487. (2003) BT-határozat 1. cikke a dátum eltérőségétől eltekintve a fentieket szó szerint átvette. 
nia-Herzegovina) folyósított anyagi finanszírozást, amennyiben a BT nem fogadja el ezen határozatokat, és nem vonja ki az amerikai katonákat az ICC joghatósága alól. ${ }^{244}$ El Zeidy és David Scheffer a határozatok „átpasszírozását” a BT-n egyértelmúen azzal magyarázzák, hogy az Egyesült Államoknak nem sikerült a BT-vel kapcsolatos elképzeléseit keresztülvinnie a római diplomáciai konferencián. ${ }^{245} \mathrm{E}$ két határozat érdekessége, hogy nem neveznek meg konkrétan olyan helyzetet, amelynek vonatkozásában az eljárást felfüggesztik, valamint nem indokolják meg, hogy mire alapozzák az ENSZ Alapokmány VII. fejezete szerinti határozat meghozatalát.

A határozatok absztrakt tartalma újabb kérdéseket vet fel. Az első és kétségkívül a legfontosabb, hogy fennálltak-e az ENSZ Alapokmány 39. cikkének feltételei, azaz kilátásban volt-e a béke veszélyeztetése vagy megszegése, illetve támadó cselekmény? A szakirodalomban uralkodó álláspont alapján a 39. cikk alkalmazásának kritériumai nem valósultak meg. Carsten Stahn véleménye szerint: „Az 1422. (2002) BT-határozattal megszületett kompromisszum elháritotta annak veszélyét, hogy a Biztonsági Tanács a jövőbeli békefenntartó müveleteket megvétózza [...] Ráadásul jelentős visszalépést jelent ahhoz képest, hogy az Egyesült Államok korábban állandó mentességet követelt az ENSZ békefenntartó müveleteiben szolgáló amerikai katonáknak."246 Stahn álláspontja értelmében ráadásul a BT az ENSZ Alapokmány VII. fejezetében szereplő hatásköreinek kereteit a végletekig feszítette, amikor a békefenntartók mentességét a nemzetközi békét és biztonságot veszélyeztető kérdésként kezelte és a 39. cikk hatálya alá vonta. ${ }^{247}$ Roberto Lavalle a fentiekkel egyetértve egyenesen „Alapokmány-ellenesnek” nevezte az 1422. (2002) határozatot, mivel az nem határozta meg sem a béke veszélyeztetését, sem a megszegését, illetve semmiféle támadó cselekményt, így nem állt rendelkezésre a BT-nek érvényes jogalap a határozat elfogadására. ${ }^{248} \mathrm{Az}$ Amnesty International úgy foglalt állást, hogy a BT azért nem kísérelte meg a béke veszélyeztetésének, megszegésének, illetve támadó cselekmény elkövetésének az alátámasztását, mert valójában egyik sem állt fenn. Az Amnesty International jelentéséhez Svájc is véleményt füzött, melyben hangot adott egyet nem értésének, miszerint nem látja, miért jelentené a nemzetközi béke és biztonság sérelmét az, ha egy nemzetközi büntetőbíróság joghatóságot gyakorol békefenntartók felett? ${ }^{249}$ Ezen érveket teljes mértékben el lehet fogadni, melyek alapján úgy tủnik, nem támasztható alá jogszerúen

\footnotetext{
244 Verduzco, 2015, 53. o.

245 El Zeidy, 2002, 1507-1508. o.; Scheffer, 2011, Chapters 7-8.

246 Stahn, 2003, 85. o.

247 Stahn, 2003, 104. o.

248 Lavalle, 2003, 195. o.

249 Amnesty International: International Criminal Court: The Unlawful Attempt by the Security Council to give US citizens Permanent Impunity from International Justice, elérhető: https://www.amnesty.org/download/ Documents/108000/ior400062003en.pdf [Letöltve: 2019. 12. 01.].
} 
az ENSZ Alapokmány 39. cikkének alkalmazása, és ebből adódóan a Római Statútum 16. cikkének alkalmazása sem.

A következő kérdés, amely a fentiekből következik, hogy vizsgálhatja-e az ICC érdemben a 39. cikk feltételeinek fennállását, vagy ha egy BT-határozat erre hivatkozik, akkor automatikusan el kell fogadnia az abban foglaltakat? Erre egyértelmüen nemleges válasz adható, tekintve, hogy a Biztonsági Tanácsot egyedül az ENSZ Alapokmány²50 24. cikk (2) bekezdése köti, az ICC tárgyalás-előkészítő tanácsai pedig nem gyakorolnak felülvizsgálati hatáskört felette. Ebből adódik az a következtetés is, hogy a 16. cikk szerinti eljárásokból teljes mértékben hiányoznak a fékek és ellensúlyok. Míg a 13. cikk b) pont szerinti aktusok esetén, azaz amikor a BT az ENSZ Alapokmány VII. fejezete alapján konfliktusos helyzetet utal a bíróság elé, a BT-határozat megszületése után először az ICC föügyésze mérlegel, hogy megindítja-e az eljárást és vádat emel-e, ${ }^{251}$ majd a tárgyalás-előkészítő tanács mérlegel, ${ }^{252}$ hogy megerősíti-e a vádat, a 16. cikk szerinti határozatokban foglaltakat a Föügyészi Hivatal és az ICC köteles tudomásul venni, mérlegelésre nincs már lehetôség.

Az 1422. (2002) és 1487. (2003) határozatok legalitásának további sarkalatos pontja, hogy a 16. cikk csak konkrét - azaz a vizsgálati szak lezárása után már megindítani tervezett vagy folyamatban lévő - nyomozás vagy büntetőeljárás során alkalmazható (konkretizáló megközelítés), avagy hatályba léphet-e egy ilyen BT-határozat még a konkrét nyomozás vagy büntetőeljárás megindítása előtt (preemptív megközelítés)? Ugyan a Római Statútum 16. cikkének szövege nem egyértelmű e kérdésben, számos szerző a travaux préparatoire alapján afelé tendál, hogy a rendelkezést konkrét eljárások során kell alkalmazni. Roberto Lavalle meglátása szerint a 16. cikk a jogalkalmazótól esetről esetre történő mérlegelést kíván meg, amihez elengedhetetlen a konkrét eljárás megléte. ${ }^{253}$ Carsten Stahn ${ }^{254}$ és Mohamed El Zeidy is hasonlóan látják, és utóbbi hozzáteszi, hogy „a Római Statútum nem határozza meg a nyomozás és büntetöeljárás fogalmát. Ugyanakkor rendelkezéseit értelmezve arra a következtetésre juthatunk, hogy a "nyomozás « egy olyan cselekményt foglal magában, amely vagy egy konkrét bíróság elötti helyzet vagy egy gyanúsítottal szemben folyik, míg a »büntetöeljárás" csakis egy meghatározott terhelttel szemben folyhat”. ${ }^{255}$ A preemptív felfüggesztés jogszerú lehetőségét a fenti szerzők tehát elvetik.

250 ENSZ Alapokmány 24. cikk (2) bekezdés: „A Biztonsági Tanácsnak e kötelességei teljesítése során az Egyesült Nemzetek céljaival és elveivel összhangban kell eljárnia. Azt a különleges hatáskört, amellyel a Biztonsági Tanács ezeknek a kötelességeknek teljesítése végettfel van ruházva, a VI., VII., VIII. és XII. fejezetek határozzák meg."

251 A nyomozás megindításáról lásd a Római Statútum 53. cikkét.

252 A tárgyalás-előkészítő tanács feladat- és hatásköreiről lásd a Római Statútum 57. cikkét.

253 Lavalle, 2003, 211. o.

254 Stahn, 2003, 89. o.

255 El Zeidy, 2002, 1512. o. 
Megválaszolásra vár az a kérdés is, hogy ki lehet-e vonni egy különleges kategóriát - mint például a jelenlegi és korábbi ENSZ-békefenntartókat - az ICC személyi joghatósága alól? A Római Statútum 27. cikkét ${ }^{256}$ olvasva bizonyossá válik, hogy a bíróság joghatósága alól nincs kivétel - legalábbis államfők, kormányfők, miniszterek, parlamenti képviselők és kormánytisztviselók vonatkozásában. Bár a határozatban megnevezett kategória nem szerepel expressis verbis a Római Statútumban, a „jelenleg vagy korábban békefenntartóként szolgáló személy" fogalom alatt olyan tág, a joghatóság alól kivont csoport érthetô, ami újfent megkérdőjelezi a 16. cikk jogpolitikai céljának teljesülését.

További kérdésként tehető fel, hogy jogszerủek-e az 1422. (2002) és 1487. (2003) BT-határozatok a tekintetben, hogy különbséget tesznek a Római Statútumban részes és harmadik államok állampolgárai között, hátrányos megkülönböztetéssel élve előbbiek javára, mivel utóbbiak korábbi és jelenlegi békefenntartóit emelik ki a határozatok az ICC személyi joghatósága alól. ${ }^{257}$ Neha Jain és Kevin Jon Heller megközelítése szerint e határozatokra a Római Statútum jogellenes kiegészítéseiként lehet tekinteni: a határozatok kivételt vájnak a statútumba, negatívan diszkriminálva a részes államok állampolgárait. ${ }^{258}$

Ám e kérdés megítélése már korántsem ilyen egyszerủ, ha az ENSZ Alapokmány 103. cikkében foglaltak felsejlenek előttünk: „Ha az Egyesült Nemzetek tagjainak a jelen Alapokmányból folyó és bármely egyéb nemzetközi megállapodásból eredő kötelezettségei összeütköznének, az Alapokmányból folyó kötelezettségeiket illeti elsőbbség." E kérdéssel korábban a Nemzetközi Bíróság a Lockerbie-ügyben ${ }^{259}$ foglalkozott, amikor is a BT az 1971. évi montreali egyezményben ${ }^{260}$ foglalt "aut dedere, aut judicare" elvtől ${ }^{261}$ eltérésre kényszerítette ${ }^{262}$ Líbiát, és kötelezte, hogy a terrorcselekménnyel gyanúsított líbiai terhelteket adja ki az Egyesült Államoknak büntetőeljárás lefolytatása céljából. Azonban - mint ahogyan arra Casten Stahn és Aly Mokhtar rámutatnak ${ }^{263}$ - a 748. (1992) BT-határozat legalitását a ICJ nem kérdőjelezte meg, ezzel szemben jelen esetben a szakirodalom kétségbe vonja az 1422. (2002) és 1487. (2003) határozatok, valamint a Római Statútum 16. cikkének alkalmazásának jogsze-

256 A rendelkezés részletes elemzését lásd Az együttmúködés, a nemzetközi elfogatóparancsok végrehajtása és a Biztonsági Tanács által kezdeményezett eljárások címú fejezetben.

257 Stahn, 2003, 93. 0.

258 Jain, 2005, 253. o.; Heller, 2013 [Online].

259 Questions of Interpretation and Application of the 1971 Montreal Convention Arising from the Aerial Incident at Lockerbie (Libya v. U.S.), 1992 I.C.J. Reports 114.

260 1973. évi 17. törvényerejű rendelet a polgári repülés biztonsága elleni jogellenes cselekmények leküzdéséről Montrealban, az 1971. évi szeptember hó 23. napján aláírt egyezmény kihirdetéséről.

261 1971. évi montreali egyezmény 7. cikk: „Ha az a Szerződő Állam, amelynek a területén a gyanúsított kézre került, a gyanúsítottat nem adja ki, köteles gondoskodni arról, hogy az ügy - mindennemü kivétel nélkül és függetlenül attól, hogy a büncselekményt a területén követték-e el - a büntetöeljárás lefolytatása céljából az illetékes hatóság elé kerüljön."

262 UN Doc. S/RES/748 (31 March 1992).

263 Stahn, 2003, 102. o.; Mokhtar, 2003, 311. o. 
rûségét. A Lockerbie-ügy és a Nemzetközi Büntetőbíróság előtti eljárás felfüggesztésének összevetését az is torzítja, hogy míg az 1971. évi montreali szerződés alanyai az államok, addig a Római Statútum normái az ICC föügyészének és bíráinak szolgálnak iránymutatásul. A bíróság a statútum 4. cikke ${ }^{264}$ értelmében önálló nemzetközi jogi jogalanyisággal bír, a BT határozatai pedig közvetlenül nem kötik, ellentétben az ENSZ-tagállamokkal, így például Líbiával.

\subsection{Az eljárás felfüggesztésére tett „kísérletek”}

Ami a nyomozás és a büntetőeljárás felfüggesztését illeti, 2008-ban az Afrikai Unió kérte az ENSZ Biztonsági Tanácsát, hogy függessze fel a dárfúri helyzet kapcsán indult, al-Bashír elleni eljárást a 16. cikk alapján, mivel az az AU meglátása szerint nem a tartós békét, a megbékélést és a konfliktus áldozatainak védelmét szolgálta, hanem tovább súlyosbította a humanitárius katasztrófát. ${ }^{265}$

Az idekapcsolódó esetjog második példája a Közép-afrikai Köztársasághoz füződik: 2008. augusztus 1-jén François Bozizé - az ország államfője - az ENSZ fôtitkárához címzett levelében a 16. cikkre hivatkozva kérte a BT-től az eljárás felfüggesztését. A közép-afrikai elnök arra kérte Ban Ki-Moon-t, hogy járjon közben a Biztonsági Tanácsnál egy olyan határozat elfogadása érdekében, amely továbbra is biztosítja a helyi hatóságok kizárólagos joghatóságát egy amnesztiáról szóló törvény által felölelt időszakban elkövetett cselekmények tekintetében (ezen törvényt az ún. átfogó békemegállapodás alapján fogadták el, mely 2008. június 21-én köttetett a közép-afrikai kormányzat, valamint három lázadó csoport között). ${ }^{266}$

Bozizé levele szerint a megkeresést az az ICC föügyészétől érkező tájékoztatás ösztönözte, miszerint a Főügyészi Hivatal kitüntetett figyelmet szentel a Közép-afrikai Köztársaság északi régiójában zajló erőszakos bűncselekmények elkövetése gyanújának. A Főügyészi Hivatal álláspontja értelmében ugyanis egyetlen, az ICC tárgyi joghatósága alá tartozó büncselekmény vonatkozásában sem lehetséges - büntethetőséget megszüntető okként - amnesztiát alkalmazni, dacára az erről szóló belső jogszabálynak. Az elnök a békefolyamat hátráltatását hozta fel indokként az ICC előtti eljárás felfüggesztésére, a helyi

264 Római Statútum 4. cikk: „(1) A Bíróság nemzetközi jogi személyiséggel rendelkezik. A feladatai elvégzéséhez és a céljai megvalósitásához szükséges jogosítványokkal is rendelkezik.

(2) A Bíróság funkcióités jogosítványait a jelen Statútumban meghatározott módon gyakorolhatja bármely Részes Állam, továbbá külön megállapodás révén, bármely más Állam területén."

265 African Union, Communique of the $142^{\text {nd }}$ Meeting of the Peace and Security Council (21 July 2008), UN Doc. S/2008/481 (23 July 2008), \$9.

266 Verduzco, 2015, 55. o. 
aktusok hiányát pedig a lázadó csoportok uralta területek „elérhetetlenségével” magyarázta. Az eset érdekessége, hogy sem arra nincs hivatalos bizonyíték, hogy az ENSZ fótitkára továbbította Bozizé levelét a BT-nek, sem arra, hogy a Biztonsági Tanács érdemben foglalkozott ezzel a megkereséssel.

Az eljárás felfüggesztése iránti harmadik kérelem Kenya kormányától érkezett az ICC-hez 2010-ben, miután a Föügyészi Hivatal proprio motu nyomozást indított a választások utáni erôszakos bủncselekmények alapos gyanúja miatt, majd hat nevesített gyanúsított ${ }^{267}$ ellen idézést adtak ki. Nem sokkal később a kenyai parlament gyorsan el is fogadott egy indítványt, amely szorgalmazta Kenya kilépését a Római Statútumból, továbbá hangsúlyozta, hogy a választások utáni (2007-2008) erőszak a helyi hatóságok kizárólagos joghatósága alá esik. ${ }^{268}$ Ezen indítvány arra ösztökélte a kenyai kormányt, hogy az Afrikai Unió támogatásával kérelmezze a Biztonsági Tanácsnál az eljárás felfüggesztését. 2011 januárjában az afrikai államfők soron következő AU-csúcsán határozott a szervezet a BT megkereséséről és Kenya kérelmének továbbításáról. Az AU kérelmét Kenya joghatóságának primátusára, valamint arra alapozták, hogy kellő időt kell hagyni az országnak, hogy felállítsanak egy speciális törvényszéket az állami szintû, belső jog alapján folyó büntetőeljárások lefolytatására. ${ }^{269}$

Végül 2011. március 18-án a Biztonsági Tanács, Kenya állandó ENSZ-képviselője és az AU tisztviselői megbeszélést tartottak az ICC előtti eljárás felfüggesztéséről, melynek eredményeképpen megállapításra került, hogy „a 16. cikk alkalmazásának feltételei nem állnak fenn”. ${ }^{270}$ A BT fó érve az eljárás fel nem függesztésére az volt, hogy az állam kérelmét a koalíciós kormányt alakító két párt közül csak az egyik támogatta. Azonban néhány nappal később Kenya kormánya megszerezte e koalíciós párt jóváhagyását is, majd tájékoztatta a BT-t, hogy a Narancs Demokratikus Mozgalom (Orange Democratic Movement) támogatja egy belső jog

267 Prosecutor's Application Pursuant to Art. 58 as to William Samuel Ruto, Henry Kiprono Kosgey, and Joshua Arap Sang, Situation in Kenya, ICC-01/09-30-REDI, PTC II, ICC, 15 December 2010; Prosecutor's Application Pursuant to Art. 58 as to Francis Kirimi Muthaura, Uhuru Muigai Kenyatta, and Mohammed Hussein Ali, Situation in Kenya, ICC-01/09-31-REDI, PTC II, ICC, 15 December 2010.

268 Parliament of Kenya, Motion No. 144 (adopted 22 December 2010). Lásd még: African Leaders Urge ICC to Drop Kenya Trials, Capital News, 27 May 2013, elérhető: https://www.capitalfm.co.ke/news/2013/05/africanleaders-urge-icc-to-drop-kenya-trials/ [Letöltve: 2019. 11. 24.]; African Union Summit on ICC Pullout over Ruto trial, BBC, 20 September 2013, elérhető: https://www.bbc.com/news/world-africa-24173557 [Letöltve: 2019. 11. 24.]; Helfer és Showalter, 2017, 1-52. o.

269 AU Assembly Decision, $16^{\text {th }}$ Session, Decision on the Implementation of the Decision on the International Criminal Court (31 January 2011), Assembly/AU/Dec.334 [XVI], \$6.

270 Quote of French Ambassador to the United Nations Ambassador Gerard Araud, 'UN Council Rejects Kenya's Deferral Bid’ Saturday Nation Kenya, 19 March 2011, elérhető https://nation.africa/kenya [Letöltve: 2019. 11. 24.]. 
alapján múködő „mechanizmus” létrehozását, amely a bưnelkövetők felelősségre vonására hivatott. ${ }^{271}$

Ez után nem sokkal, 2011. április 8-án a BT újabb megbeszélést hívott össze, majd bejelentették, hogy „a Biztonsági Tanács tagjai alapos mérlegelés után a kérdésben nem tudtak megegyezni”. ${ }^{272} \mathrm{~A}$ BT elnöke nyilatkozatában arról nem számolt be, hogy a BT tagjai Kenya érveivel nem értettek egyet, vagy hogy egymás között nem tudtak megegyezni az eljárás felfüggesztéséról. A Föügyészi Hivatal mindenesetre tovább folytatta az eljárást, és végül a hatból három terhelt ellen (Uhuru Kenyatta, William Ruto és Joshua Arap Sang) emelt vádat. Kenya eljárási képességének és hajlandóságának vizsgálata után pedig megállapították, hogy a Nemzetközi Büntetőbíróság joghatósággal rendelkezik a komplementaritás elve alapján. Az ügy 2013 márciusában újfent felszínre tört, amikor is - a választásokat megnyerve - Kenyattát Kenya elnökévé, Rutót pedig alelnökké választották. Kenya az AU és az ENSZ Közgyưlésének közbenjárásával újabb megbeszélés összehívását kérelmezte 2013. május 23-án, illetve levelek sorozatában kérelmezte a BT-nél az eljárás felfüggesztését. Az események végül ahhoz vezettek, hogy Marokkó, Ruanda és Togó előkészítették az eljárás felfüggesztéséről szóló BT-határozat tervezetét, ám az a szavazás során nem kapott a Biztonsági Tanácsban elég támogatást. ${ }^{273}$

Szudán, a Közép-afrikai Köztársaság és Kenya példájából az alábbi következtetések vonhatók le: (i) nem létezik egységes értelmezési gyakorlat az eljárás felfüggesztésének feltételeit, különösen az ENSZ Alapokmány 39. cikkében foglaltakat tekintve; (ii) nem létezik megfelelő "follow-up" eljárás a 16. cikk alapján benyújtott kérelem elutasítása esetén (átláthatóság és a nem várt kimenetelből adódó feszültségek hathatós kezelésének hiánya); valamint (iii) nem léteznek fékek és ellensúlyok a Római Statútum normáinak ilyen esetekben történő betartásának felügyeletére. (Például ilyen esetben nem lehet kifogást benyújtani a hatáskörrel rendelkező tárgyalás-előkészítő tanácshoz, tekintve, hogy az ICC - értelemszerúen nem kompetens a BT ellenőrzésében.)

Annak ellenére, hogy a 16. cikk a Nemzetközi Büntetőbíróság és a Biztonsági Tanács viszonyrendszerének kardinális jelentőségú normája, gyakorlati érvényesülése csekély figye-

271 Letter to the Security Council, Request of Kenya for Deferral under Article 16 of the Rome Statute (29 March 2011), UN Doc. S/2011/201.

272 Press Statement by the President of the Council Ambassador Nestor Osorio on the Request of Kenya for Deferral under Article 16 of the Rome Statute, UN Media Stakeout, 5:05 (8 April 2011), elérhető: https://www. unmultimedia.org/tv/webcast/2011/04/sc-president-nestor-osorio-colombia-on-dr-congo-security-council-media-stakeout-2.html [Letöltve: 2019 . 11. 24.].

273 A határozat megszületése mellett voksoltak Azerbajdzsán, Kína, Marokkó, Pakisztán, Oroszország, Ruanda és Togo (a Római Statútumban egyik sem részes állam); Argentína, Ausztrália, az Egyesült Királyság, Franciaország, Guatemala, Luxemburg, Dél-Korea (részes államok) és az USA (nem részes fél) pedig tartózkodtak. UN Doc. S/2013/660 (15 November 2013); UN Doc. S/PV.7060 (15 November 2013). 
lemben részesült az ENSZ-ben. E rendelkezés alkalmazása tekintetében is felvillantható a BT által előszeretettel vallott ,jogi minimalizmus” - tekintve például az al-Bashír-ügyet, amikor nem érkezett válasz az AU Közgyưlésének eljárásfelfüggesztő kérelmére, vagy amikor Kenya esetében elmaradt a nyilvános vita a BT-ben, valamint nem vettek fel a megbeszélésekrôl hivatalos jegyzőkönyvet sem. A fenti esetek kontraproduktívan hatottak a 16. cikk gyakorlati átültetésére, hiszen csak feszültséget és gyanút szültek a tekintetben, hogy a BT nem veszi érdemben figyelembe az AU által elöterjesztett kérelmeket.

Végül meg kell említeni, hogy a nyomozás vagy büntetőeljárás felfüggesztése a procedúra résztvevőire is negatív kihatással lehet: a terhelt tisztességes eljáráshoz való joga, az áldozatok eljárásban való részvételének joga, valamint nemzetközi fegyveres összeütközések, határokon átnyúló konfliktusok esetén egy Római Statútumban nem részes államok érdeke is sérül vagy sérülhet az eljárás elhúzódása miatt.

Összegezve tehát a fentebb leírtakat: a Római Statútum 16. cikke szerinti eljárás csak abban az esetben jogszerú, ha (i) a béke veszélyeztetése, megsértése fennáll, illetve támadó cselekményt követtek el; és (ii) folyamatban van olyan vizsgálat, nyomozás vagy büntetőeljárás, amelyet fel lehet függeszteni. Az ICC előtti eljárások felfüggesztése nem megalapozott az ENSZ Alapokmány VII. fejezetében foglaltak és konkrét, folyamatban lévő vizsgálat vagy eljárás hiányában. Így az eljárások preemptív felfüggesztése jogellenesnek minősül az ENSZ Alapokmány és a Római Statútum rendelkezéseinek értelmében. 
III.

RÉSZ

A Nemzetközi Büntetőbíróság

és a Biztonsági Tanács

kapcsolatának gyakorlati problémái 


\section{A Nemzetközi Büntetőbíróság és harmadik államok}

\subsection{A harmadik államok jogállásának lényeges nemzetközi jogi vetületei a Római Statútum szempontjából}

A következő fejezet a Nemzetközi Büntetőbíróság harmadik államokkal való kapcsolatát tekinti át, ugyanis a kötet későbbi részeiben tárgyalt, a joggyakorlatot kihívások elé állító problémák megértése érdekében fontos látni, hogy a BT által az ICC elé utalt helyzetekben harmadik államokról van szó, azaz a Biztonsági Tanács határozataival olyan országok kerültek a büntetőbírói fórum elé, amelyek nem ratifikálták a Római Statútumot. Ahogyan arról már korábban szó esett, a bíróság szerződéses rezsimje sajátosan érvényesül - vagy helyenként nem is érvényesül ${ }^{274}$ - akkor, ha az ENSZ főszerve kezdeményezte az ICC előtti eljárást.

A Római Statútumot megerősítő államok száma bizonyos értelemben győzedelmes diadalnak tekinthető, különösen akkor, ha figyelembe vesszük, hogy a nemzetközi jogban vízválasztónak számító öt éven belül sikerült elérni a hatálybalépéshez szükséges 60 ratifikációt. ${ }^{275}$ 2021-ben - e sorok írásakor - a statútum részes államainak száma 123,276 ami a nemzetközi közösség államainak majdnem kétharmadát felöleli, ám ha ezen államok népességszámát is figyelembe vesszük, akkor láthatjuk, hogy az emberiségnek csupán kevesebb mint a fele tartozik a szerződés területi joghatósága alá. Nem részes felek a Római Statútumban az Egyesült Államok, Kína és Oroszország sem, melyek a Biztonsági Tanács állandó tagjainak háromötödét teszik ki. A fentiekből kitûnik, hogy igen jelentős azoknak az államoknak a száma, népessége és politikai potenciálja, amelyek a Római Statútum vonatkozásában harmadik államoknak minősülnek, azaz a Nemzetközi Büntetőbíróságot létrehozó nemzetközi szerződést nem írták alá, nem erősítettek meg, vagy nem csatlakoztak hozzá.

274 Erre jó példa a Római Statútum 12. cikk (2) bekezdése.

275 A praktikusabb szemléltetés kedvéért álljon itt néhány statisztikai adat. A világ tíz legnépesebb országából csupán négy részes állam: Banglades, Brazília, Japán és Nigéria igen, míg az Egyesült Államok, India, Indonézia, Kína, Oroszország és Pakisztán nem. A világ húsz legnépesebb országából pedig csak nyolc tagállama van a Római Statútumnak. Ezek a fentebb felsorakoztatott államok, továbbá a Fülöp-szigetek, a Kongói Demokratikus Köztársaság, Mexikó és Németország. Egyiptom, Etiópia, Irán, Thaiföld, Törökország és Vietnám nem részes felek a statútumban. A Római Statútum részes feleiről lásd: https://asp.icc-cpi.int/ en_menus/asp/states\%20parties/Pages/states\%20parties\%20_\%20chronological\%2olist.aspx [Letöltve: 2019. 12. 14.].

276 A Római Statútum részes államainak kronologikus sorrendjét lásd: https://asp.icc-cpi.int/en_menus/asp/ states $\% 20$ parties/pages/the\%2ostates\%20parties\%20to\%20the\%20rome\%20statute.aspx [Letöltve: 2021.04 . 30.]. 
Az államok közötti nemzetközi szerződések jogáról szóló 1969. évi bécsi egyezmény ${ }^{277}$ 34. cikke kimondja, hogy „a szerződés harmadik állam ${ }^{278}$ számára - annak beleegyezése nélkül sem kötelezettségeket, sem jogokat nem hoz létre". E norma, mely hủen tükrözi a nemzetközi jog egyik klasszikus alapelvét, azaz az államok szuverén egyenlőségét, ebből adódóan pedig a beleegyezés, az önkéntes alávetés kulcsfontosságú szerepét, egészen a római jogig visszanyúló gyökerekkel bír (pacta tertiis nec nocent nec prosunt), ${ }^{279}$ és a nemzetközi bírói fórumok is többször vizsgálták.

Az Állandó Nemzetközi Bíróság a harmadik államok jogaival kapcsolatban 1926-ban a bizonyos lengyel felsö-sziléziai német érdekek ügyében rögzítette, hogy „egy szerződés a törvény erejével csak az abban részes államok között birr; e szerződés kétség esetén harmadik államok javára jogokat nem keletkeztet”, ${ }^{280}$ míg a harmadik államok kötelezettségei vonatkozásában 1932-ben a felsö-szavojai és Gex tartománybeli vámszabad övezetek ügyében úgy foglalt állást, hogy a versailles-i szerződés ${ }^{281}$ Svájcot akarata ellenére nem kötelezte. ${ }^{282}$ A Nemzetközi Bíróság az elv ugyanezen részét 1969-ben az északi-tengeri kontinentális talapzat ügyekben megerősítette, amikor kimondta, hogy az egyenlô távolságok elve nem tartozik a nemzetközi jog szokásjogi normái közé, és mivel a Német Szövetségi Köztársaság nem ratifikálta az 1958. évi genfi egyezményt, ${ }^{283}$ 1́gy a kontinentális talapzat elhatárolására szolgáló szerződéses szabályt vele szemben nem lehet alkalmazni. ${ }^{284}$

A szerződések relatív hatályának elve kétségkívül a szokásjog részét képezi, ${ }^{285}$ ugyanakkor nem tartozik a nemzetközi jog kógens normái közé, feltétlen alkalmazást nem vindikál. Ahogyan arra Szalai Anikó rámutat, „kivételes esetben a nemzetközi szerződés kihathat

277 1987. évi 12. törvényerejû́ rendelet a szerződések jogáról szóló, Bécsben az 1969. évi május hó 23. napján kelt szerződés kihirdetéséről 1987. szeptember 15-én.

278 1969. évi bécsi egyezmény 1. cikk h) pont: „a »harmadik állam« olyan államot jelent, amely nem részese a szerződésnek".

279 Corten és Klein, 2011, 467. o.

280 Certain German Interests in Polish Upper Silesia Case (Germany v. Poland), Judgment No. 7. 25 May 1926. P.C.I.J. Series A, No. 7, 30.

281 1919. évi versailles-i szerződés 435. cikk. 1921. évi XXXIII. törvénycikk az Észak-amerikai Egyesült Államokkal, a Brit Birodalommal, Franciaországgal, Olaszországgal és Japánnal, továbbá Belgiummal, Kínával, Kubával, Görögországgal, Nicaraguával, Panamával, Lengyelországgal, Portugáliával, Romániával, a SzerbHorvát-Szlovén Állammal, Sziámmal és Cseh-Szlovákországgal 1920. évi június hó 4. napján a Trianonban kötött békeszerződés becikkelyezéséről.

282 Free Zones Case of Upper Savoy and the District of Gex Case (France v. Switzerland), Judgment No. 46. 7 June 1932. P.C.I.J. Series A/B, No. 46, \$141.

283 1963. évi 6. törvényerejü rendelet a nyílt tengerről szóló, Genfben, 1958. április 29-én aláírt szerződés kihirdetéséről.

284 North Sea Continental Shelf Cases (Federal Republic of Germany v. Denmark and the Netherlands), Judgment of 20 February 1969, I.C.J. Reports 1969.

285 Villiger, 2009. 472. o. 
a nemzetközi jog más alanyaira is, anélkül, hogy ők a szerződésben részes féllé válnának", ${ }^{286}$ azaz a föszabály alóli kivételek lehetősége megengedett. Kovács Péter hét ilyen kivételt sorol fel, melyek a következők: (i) önkéntes kötelezettségvállalás az állam részéről; (ii) a szerződésben nem részes fél számára szóló ígérvény; (iii) érintkező megállapodások; (iv) a legnagyobb kedvezmény elvét alkalmazó szerződéses kapcsolatok; (v) az objektív helyzetet létesítő megállapodások; (vi) a ius cogens tartalmú szerződések; valamint (vii) a tiszta szokásjogi kodifikációs egyezmények. ${ }^{287}$

Szintúgy a pacta tertiis nec nocent nec prosunt elv jogszerú áttörésének minősül az ENSZ Alapokmány 108. cikkében szereplő eset, mely szerint „a jelen Alapokmány módosítása az Egyesült Nemzetek összes tagjaira nézve akkor lép hatályba, ha azt a Közgyülés tagjai kétharmad szótöbbséggel elfogadták, és az Egyesült Nemzetek tagjainak kétharmada, köztük a Biztonsági Tanács valamennyi állandó tagja, saját alkotmányos eljárásának megfelelően megerösítette". E rendelkezésből az következik, hogy az Alapokmány módosításának - mind az elfogadás, mind a ratifikáció tekintetében - elégséges feltétele, ha a szervezet összes tagjának kétharmada megszavazza és megerősíti azt (már amennyiben a kétharmados többség a BT állandó tagjait magában foglalja). ${ }^{288}$ Így a módosítást meg nem szavazó állammal szemben a módosított rendelkezés ugyanúgy hatályosul, mintha igennel szavazott volna (persze azt a valószínútlen esetet leszámítva, ha a módosítás miatt felmondja az ENSZ Alapokmányt, és kilép a nemzetközi szervezetből). ${ }^{289}$

Ami a Római Statútumot illeti, a szerződések relatív hatályának elvét az ICC tárgyalás-előkészítő tanácsa a bírósággal való együttmúködéssel kapcsolatban vizsgálta, és kimondta, hogy „csak a Római Statútum részes államai tartoznak együttmüködési kötelezettséggel a Bíróság felé. Tekintve, hogy a Statútum egy nemzetközi szerződés, vonatkoznak rá az 1969. évi bécsi egyezményben foglaltak, és a Statútum kizárólag csak akkor róhat kötelezettséget egy nem részes államra, ha az ebbe beleegyezett". ${ }^{290}$

286 Szalai, 2018, 46. o.

287 Kovács, 2016, 149-150. o.

288 Az ENSZ Alapokmányát négyszer módosították a '60-as években és egyszer 1973-ban, amelyek csupán a BT létszámának felemelését, a határozathozatalhoz szükséges többség módosítását és a Gazdasági és Szociális Tanács létszámának felemelését fogták át. Lásd: Sulyok, 2009, 125-189. o.

289 Az ENSZ-ből való kilépésre eddig egyszer került sor, akkor sem az Alapokmány módosítása miatt. 1965-ben Indonézia arról értesítette az ENSZ akkori főtitkárát, hogy felfüggeszti részvételét a nemzetközi szervezetben, válaszul arra, hogy Malajziát nem állandó BT-taggá választották. Ugyanakkor Indonézia távolmaradása nem tartott sokáig: az egy évvel később ténylegesen bekövetkezett kormányváltás után az állam ismét jelezte együttmúködési hajlandóságát a footitkár irányába, valamint részvételi szándékát a Közgyưlés következő ülésszakán. Lásd erről bővebben: Schwelb, 1967, 661-672. o.

290 Decision Regarding Omar Al-Bashir's Potential Travel to the State of Kuwait, The Prosecutor v. Omar Hassan Ahmad Al-Bashir, ICC-02/05-01/09-192, Pre-Trial Chamber II, 24 March 2014 (a hivatkozásokban a továbbiakban: Kuvait-határozat). 
Noha nem a harmadik államok jogállásához, hanem a Római Statútum értelmezése során alkalmazandó módszerekhez kapcsolódik, érdekességként érdemes e ponton felvillantani, hogy a nemzetközi büntetőjogi szakirodalomban felbukkant egy olyan álláspont, mely szerint az 1969. évi bécsi egyezmény szabályait bizonyos esetekben nemcsak hogy nem kell, nem is lehet a statútumra alkalmazni. Dov Jacobs amellett érvel, hogy a nemzetközi büntetőbíróságok joggyakorlata kevés figyelmet szentel a nemzetközi büntetőjog speciális természetének, kiváltképpen a törvényesség elve átható karakterének, és az 1969. évi bécsi egyezmény alkalmazhatóságát a büntetőjogi instrumentumok vonatkozásában eleve adottnak veszi. Jacobs a Római Statútum speciális szabályozási tárgyából, annak „kétarcúságából" indul ki: a statútum egyfelől a Nemzetközi Büntetőbíróság alapszabálya, büntető anyagi és eljárásjogi normák kódexe (például II. Fejezet - Joghatóság, elfogadhatóság és alkalmazandó jog), másfelól államok közötti kapcsolatokat szabályozó, hagyományos értelemben vett nemzetközi szerződés (például IX. Fejezet - Nemzetközi együttmúködés és jogsegély). E Janus-arcúság pedig a jogalkalmazótól eltérő értelmezési módszert kíván meg: ha a statútum „klasszikus nemzetközi szerződésként” viselkedik, akkor az 1969. évi bécsi egyezmény szabályai alkalmazandók rá, így például a harmadik államok jogai és kötelezettségei esetén. Ám ha alkalmazása során a statútum büntető anyagi és eljárásjogi kódexként funkcionál, akkor az 1969. évi bécsi egyezmény értelmezésre vonatkozó normái háttérbe szorulnak, mintegy másodlagossá válnak, és a büntetőjog eszköztára válik lex specialisszá. Eszerint például az in dubio pro reo elv alapján nem az 1969. évi bécsi egyezmény nyelvtani értelmezésre vonatkozó normáját kell segítségül hívni akkor, amikor a terheltre nézve kedvezőbb értelmezési eredményt elérő szabályt is alkalmazhatunk. ${ }^{291} \mathrm{~A}$ fentiekből az következik, hogy az 1969. évi bécsi egyezmény szabályainak alkalmazása nemcsak a harmadik államokra vonatkozó szabály, hanem más normák tekintetében is mint lex generalis funkcionál.

A harmadik államok jogállása tekintetében érdemes még egy számottevő, a jog világán túlmutató tényezőről szót ejteni, amire Mahnoush Arsanjani és Michael Resiman úgy utalnak, hogy a "múködésben lévő jog” (law-in-action), ${ }^{292}$ mely egy olyan íratlan, háttérszabályrendszert takar, amelyet a Római Statútum normáit fürkészve aligha lehet felfedni, ám mégis markáns színezetet ad a bíróság és harmadik államok viszonyának. Ez a „múködésben lévő jog” pedig nem más, mint a diplomácia. Annak ellenére, hogy a Nemzetközi Büntetőbíróság jog alkotta intézmény, egy olyan világban létezik, amelyet a politika szálai átszőnek, és ha az ICC bizonyos célokat el akar érni, akkor diplomáciai tevékenységbe kell bocsátkoznia, például azért, hogy új államok csatlakozzanak a Római

291 Jacobs, 2013 [Online].

292 Arsanjani és Resiman, 2005, 385. o. 
Statútumhoz, vagy azért, hogy akár a harmadik, akár a részes államokat az együttmúködésre rábírja. Mivel a harmadik államok által tanúsított együttmúködés pusztán a jóakarat függvénye, és a részes államok vonatkozásában sincsenek elrettentő szankciók kilátásba helyezve arra az esetre nézve, ha valamelyikük vonakodik a bírósággal együttmû́ködni, az ICC egyetlen eszköze a hajlandóság erősítésére a diplomácia marad ${ }^{293}$ márpedig az együttmúködés sikere a bíróság hatékonyságának és megítélésének egyik legjelentősebb fokmérője.

\subsection{A harmadik államok jogállása a Római Statútumban}

A Római Statútumban nem részes államok jogállását négy szempont szerint csoportosíthatjuk: (i) van fennálló kötelezettségük; (ii) lehetnek beálló kötelezettségeik; (iii) lehet kötelezettségnek nem minősülő jogi érintettségük; valamint (iv) vannak jogosultságaik is, amelyek az általános szerződéses gyakorlatban megszokottnál szélesebb körben illetik meg a statútumban nem részes államokat.

(i) Annak ellenére, hogy nem közvetlenül a Római Statútum valamely rendelkezésén alapul, a harmadik államok jogállásának tárgyalásánál elsőként tart említésre számot az objektív jogalanyiság kérdése, azaz hogy a Nemzetközi Büntetőbíróság jogalanyisága inter partes vagy erga omnes természetû́-e. Előbbi arra utal, amikor egy jogalany (nemzetközi szervezet vagy bíróság) jogalanyiságát csak a jogalanyt létrehozó nemzetközi instrumentumban részes feleknek kell elismerni, azaz a kívülállók részéről az sem jogellenes magatartás, ha az adott entitást nem létezőnek tekintik. Az erga omnes jogalanyiság azonban a nem részes felekkel szemben is hatályos, azaz az ilyen entitást nem lehet egyszerúen „semmibe venni”. Az ICC és harmadik államok viszonyában tehát ennek megítélése azt dönti el, hogy a Római Statútumban nem részes felek kötelesek-e a bíróságot nemzetközi jogalanyként elismerni.

A Nemzetközi Bíróság az objektív jogalanyiság kérdésével 1949-ben a Bernadotteügyben foglalkozott, amikor tanácsadó véleményében megállapította, hogy a tagállamok magas száma az ENSZ erga omnes jogalanyiságát megalapozza, ${ }^{294}$ így a szervezet felléphetett a főtitkár különmegbízottjának megölése ügyében az akkor még nem ENSZ-tagállam Izraellel szemben. Kovács Péter kiemeli, hogy a nemzetközi szervezetek és bíróságok objektív jogalanyiságának megítélésében kulcsfontosságú, hogy a Bernadotte-ügyben megállapított kritériumoknak az adott intézmény megfelel-e. Ennek kapcsán azt is hangsú-

293 Cryer, 2015, 262. o.

294 Reparation of Injuries Suffered in the Service of the United Nations, Advisory Opinion of 11 April 1949, I.C.J. Reports 1949, 185. \$. 
lyozza, hogy a szakirodalomban három lehetséges elmélet uralkodik az ICC objektív jogalanyiságáról: egy megerősítő - mely általában elfogadja a nemzetközi szervezetek objektív jogalanyiságát, és kívánatosnak is tartja azt -, egy elutasító és egy hezitáló - mely utóbbi szerint a kérdést csak az ICC és harmadik államok együttes gyakorlata alapján lehet megválaszolni. ${ }^{295}$

A Nemzetközi Büntetőbíróság tárgyalás-elókészítő tanácsa 2018 szeptemberében tanácsadó véleményt adott ki a bíróság Főügyészi Hivatalának kérelmére, melynek tárgya a joghatóság fennállása volt a rohingyák Bangladesbe deportálásának ügyében. ${ }^{296}$ Bár a tanács maga is megjegyezte, hogy a kérelem szorosan vett tárgyához a bíróság jogalanyiságának kérdése nem tartozik hozzá, véleményében ezzel az aspektussal is foglalkozott. Az ICC eljáró tanácsa a Nemzetközi Bíróság érvelését tartalmi szempontból lényegében véve átemelte: „E tanács álláspontja szerint a nemzetközi közösséget képviselō több mint 120 állam a nemzetközi joggal összhangban rendelkezik azzal a felhatalmazással, hogy egy objektív és ne csak általuk elismert jogalanyisággal bíró, »Nemzetközi Büntetőbiróságnak« nevezett entitást hozzon létre, és amely rendelkezik azzal a képességgel, hogy felvegye a nemzetközi közösség egészét érintő legsúlyosabb büntettek elleni harcot a komplementaritás szabta keretek között. Tehát az ICC létezése objektív tény. Másfelöl, az ICC egy olyan »jogi-bírói-intézményes« (»legal-judicial-institutional«) fórum, amely nemcsak magas számú részes államával, hanem - akár a Római Statútumot aláiró, akár alá nem író - nem részes államokkal is foglalkozottés együttmúködött." ${ }^{297}$ Mind az ICJ, mind az ICC érvelésének középpontjában kvantitatív szempont áll: az ENSZ Alapokmányban, illetve a Római Statútumban részes államok magas számára, a nemzetközi közösség menynyiségi reprezentativitására hivatkozva állapítják meg az ENSZ és a Nemzetközi Büntetőbíróság objektív jogalanyiságát.

Kovács Péter is meggyőzően érvel az ICC objektív jogalanyisága mellett: hangsúlyozza a bíróság harmadik államokkal történő együttmúködésének eddigi sikereit, valamint a BT Római Statútum 13. cikk b) pontja alatti jogosultságát, miszerint nem részes államok helyzeteit terjesztheti a bíróság elé. Meglátása szerint a statútumban található részes és nem részes államok közötti számos megkülönböztetés az ICC jogi személyiségére nincs közvetlen kihatással, az erga omnes természetű. (Továbbá záróakkordként azt is hozzáteszi, hogy „[...] vagy ha nem az, akkor annak kellene lennie".). ${ }^{298}$

295 Kovács, 2019a, 225-227. 0.

296 A rohingya-válság súlyos menekültügyi vonatkozásairól lásd részletesen az ENSZ menekültügyi szervezetének honlapját: https://www.unhcr.org/rohingya-emergency.html [Letöltve: 2021. 04. 25.].

297 Decision on the Prosecution's Request for a Ruling on Jurisdiction under Article 19(3) of the Statute, Preliminary examination of the Bangladesh / Myanmar Situation, ICC-RoC46(3)-01/18, Pre-Trial Chamber I, 6 September 2018. $\$ 48$.

298 Kovács, 2019a, 243. o. 
(ii) A beálló kötelezettség kifejezés arra utal, hogy az ilyen kötelezettség fennállása egy előfeltétel bekövetkezésétől függ, melynek jogszabályi háttere - a már korábban tárgyalt a Római Statútum 13. cikk b) pontjában érhető tetten. A bíróság elé utalás Ádány Tamás szavaival élve "a nemzetközi jog nyelvére lefordítva a Biztonsági Tanács ilyen tartalmú határozatát jelenti", 299 azaz ha a BT egy olyan nemzetközi békét és biztonságot veszélyeztető vagy sértő helyzetet utal az ICC elé, mellyel kapcsolatban feltehető, hogy a bíróság tárgyi joghatóságába tartozó bûntetteket követtek el, akkor kötelezettségek sorozata áll be az érintett állam(ok)ra nézve. Ezen határozatok érintettjei pedig az eddigi gyakorlat tükrében harmadik államok, ami logikusan következik abból az eljárásjogi könnyebbségből, hogy a részes államokban elkövetett nemzetközi bủntettek alapos gyanúja esetén a bíróság föügyésze ex officio kezdeményezheti az eljárást.

(iii) Jóllehet a kötelezettségnek nem minősülő jogi érintettség a harmadik államokat jellemzően bevett mértékú szuverenitáskorlátozással járó tûrésre kötelezi - tekintve, hogy az állam csak közvetett kötelezett a büntetőjogi felelősségre vont egyén után -, ezért ezen esetkört - amikor egy nemzetközi szerződés egy harmadik állam érdekére kihatással van, ám számára sem jogokat, sem kötelezettségeket nem keletkeztet - kifejezóbb érintettségnek, semmint passzív kötelezettségnek nevezni.

Az univerzális joghatóságot kategorikusan elvetve, a Római Statútum végleges normaszövege - a 12. cikk (2) bekezdése - a területi elv értelmében a nemzetközi büntetôbírói fórum büntetőhatalom-gyakorlását harmadik állam állampolgárai felett is megalapozza, majd a 12. cikk (3) bekezdése hozzáfúzi, hogy „ha Bíróság joghatóságának olyan állam általi elfogadása szükséges a (2) bekezdés szerinti célból, amely a jelen Statútumban nem részes állam, az adott állam a hivatalvezetőhöz benyújtott nyilatkozattal elfogadhatja az adott büntett tekintetében a Bíróság joghatóságát. Az elfogadó állam késedelem és kivétel nélkül a IX. Fejezetben meghatározottak szerint együttmúködik a Bírósággal". Így - nem számolva azzal az esettel, amikor a BT az ENSZ Alapokmányának VII. fejezete alapján, a Római Statútum 13. cikk b) pontjával összhangban utal egy nem részes állam területén dúló fegyveres konfliktust az ICC elé - a bíróság két esetben gyakorolhatja joghatóságát oly módon, mely harmadik állam érdekeit - és esetlegesen jogait is - érinti. ${ }^{300}$

Az első ezek közül, amikor olyan büncselekmények elkövetése miatt indul eljárás, amelyeket ugyan harmadik állam területén, ám részes felek állampolgárai követtek el. Utóbbi rendelkezés sohasem vívta ki a nem részes államok „ellenszenvét”, ellentétben a másik lehetőséggel, mely alapján harmadik felek állampolgárai által részes államok területén elkövetett bûntettek miatt indíthat az ICC föügyésze nyomozást. Részben e

299 Ádány, 2014, 179. o.

300 Ramanathan, 2005, 627-634., o. 
rendelkezésben rejlik az az ok, amely az ICC kitartó kritikusává avanzsálta az Egyesült Államokat, egyéb harmadik államokkal, például Indiával, Iránnal vagy Kínával egyetemben. ${ }^{301}$

Az Egyesült Államok többször tett bizonyítási kísérletet arra nézve, hogy a területi joghatóság ezen alesete a pacta tertiis nec nocent nec prosunt szokásjogi normáját sérti, és ebből adódóan az egész nemzetközi szerződés jogellenessége is kimondható. ${ }^{302} \mathrm{~A}$ szuperhatalom ellenszenvére és az e rendelkezésből adódó gyakorlati nehézségekre a közelmúlt eseményei szemléletes példával szolgálnak. 2019 áprilisában az ICC tárgyalás-előkészítő tanácsa nagy visszhangot keltett, amikor elutasította a föügyész arra vonatkozó indítványát, hogy az afganisztáni helyzetben nyomozást indítson. Afganisztán a Római Statútum részes állama, ugyanakkor a Főügyészi Hivatal által kezdeményezett előzetes vizsgálat nem csupán afgán állampolgárok, hanem Afganisztán területén más állam honosai által elkövetni vélt bűntettekre is fényt derített. A föügyész bizonyítékai értelmében alapos gyanú állt fenn arra nézve, hogy mind az amerikai fegyveres erők, mind az amerikai Központi Hírszerző Ügynökség (Central Intelligence Agency) tagjai háborús bưntetteket követtek el a 2001. szeptember 11-én történt terrortámadások kapcsán folytatott kihallgatások során.

A föügyészi indítvány szerint sokakat elfogtak, majd speciális fogvatartási központokba szállították őket annak gyanújával, hogy az al-Kaida, illetve a tálib fegyveres erők tagjai vagy a terrorszervezet szimpatizánsai, majd a harcolni nem képes fogvatartottakkal és a harcokban aktívan részt nem vevő civilekkel szemben a kihallgatások során kínzást, valamint kegyetlen, embertelen és megalázó bánásmódot követtek el. A tárgyalás-előkészítő tanács határozatában arra hivatkozott, hogy az események óta eltelt hosszú időtartam miatt a nyomozás engedélyezése már nem szolgálná az igazság érdekét. ${ }^{303} \mathrm{E}$ helyütt megjegyzendő, hogy a bíróság végső érve a nyomozás megindítása ellen meglehetősen puritán, melynek meggyőzőerejét tovább árnyalja a határozat megszületését megelőző heves tiltakozás az Egyesült Államok részéről: 2019 márciusában az amerikai külügyminiszter, Mike Pompeo kilátásba helyezte, hogy vissza fogják vonni vagy meg fogják tagadni a beutazási vízumot mind a bíróság fő̈gyészétől, mind a többi tisztviselőjétől, melyet nem sokkal a határozat megszületése előtt végül visszavontak. ${ }^{304}$

301 Lásd erről bővebben: Hirad, 2005, 635-648. o.; Zhu, 2014, 43-67. o.

302 Béres, 2015, 203-212. o.

303 Decision Pursuant to Article 15 of the Rome Statute on the Authorization of an Investigation into the Situation in the Islamic Republic of Afghanistan, Situation in Afghanistan, The Prosecutor v. Omar Hassan Ahmad Al-Bashir, ICC-02/17, Pre-Trial Chamber II, 12 April 2019.

304 A külügyminiszer nyilatkozata a világsajtóban is felkapott téma volt: https://www.reuters.com/article/ us-usa-icc-prosecutor/u-s-revokes-icc-prosecutors-entry-visa-over-afghanistan-investigation-idUSKCN1RG2NP [Letöltve: 2019. 05. 19.]; https://edition.cnn.com/2019/04/05/politics/icc-prosecutor-visa-revoked/ 
(iv) A Római Statútumban számos harmadik államok jogaira vonatkozó rendelkezést találhatunk. Ez részben azon államok eredményes közbenjárásának köszönhető, melyek ugyan részt vettek az 1998. évi római diplomáciai konferencián, ám egyáltalán nem állt szándékukban csatlakozni a szerződéshez. Robert Cryer meglátása szerint a csatlakozni nem kívánó államok száma végül azért lett annyira magas - és ebből adódóan a harmadik államokat érintő cikkek azért annyira gyakoriak és gondosan kimunkáltak a statútumban -, mert a kodifikációban részt vett államok többsége elutasította az Egyesült Államok azon javaslatát, miszerint az ICC csak akkor gyakorolhatott volna joghatóságot egy ügyben, ha mind az elkövetés helye szerinti, mind az elkövető állampolgársága szerinti állam részes fél a Római Statútumban. ${ }^{305}$

Általánosságban elmondható, hogy a Római Statútum a nem részes államokat számottevő jogi garanciákban részesíti. Ennek a kitüntetett figyelemnek a 18. cikk (1) bekezdése remek példája: „ha egy esetet a 13. cikk a) bekezdése alapján a Bíróság elé terjesztettek, és a föügyész úgy döntött, hogy a nyomozás meginditása indokolt, vagy a föügyész kezdeményezi a nyomozás meginditását a 13. cikk c) bekezdése és a 15. cikk szerint, a föügyész értesíti az összes részes államot és azon államokat, amelyek, a rendelkezésre álló adatokra figyelemmel, az adott büntettek felett általában joghatósággal rendelkeznének". A részes államok és államok megkülönböztetése beszédes: a fôügyésznek nemcsak a statútumban részes felek, hanem harmadik államok vonatkozásában is értesítési kötelezettsége áll fenn.

Szintúgy szemléletes példa, hogy a Római Statútum 18. cikk (2) bekezdése ${ }^{306}$ értelmében a nem részes felek elfogadhatósági kifogással élhetnek a bíróság elé került ügyek vonatkozásában. Utóbbi az 1969. évi bécsi egyezmény 36. cikk (1) bekezdésének hatálya alá tartozó eset, mely szerint: „a szerzódés valamely rendelkezése harmadik állam számára akkor teremt jogokat, ha a részes felek szándéka arra irányul, hogy e rendelkezéssel a harmadik államnak, vagy államok csoportjának, amelyhez a harmadik állam tartozik, vagy valamennyi államnak e jogokat megadják, és a harmadik állam ebbe beleegyezik. A harmadik állam beleegyezését mindaddig vélelmezni kell, amíg az ellenkezője nem tünik ki, feltéve, hogy a szerzödés másképpen nem rendelkezik. (2) Annak az államnak, amely az (1) bekezdésnek megfelelő jogával él, e jogot olyan feltételek mellett kell gyakorolnia, ahogy azt a szerződés elöirja, vagy ahogy ezt a szerződéssel összhangban

index.html [Letöltve: 2019. 05. 19.]; https://www.bbc.com/news/world-us-canada-47822839 [Letöltve: 2019. 05. 19.].

305 Cryer, 2015, 265. o.

306 Római Statútum 18. cikk (2) bekezdés: „az értesités átvételétôl számított egy hónapon belül az állam értesitheti a Bíróságot, hogy állampolgárai, vagy a joghatósága alá tartozó más személyek ügyében megindítja vagy megindította a nyomozást az 5 . cikkben írt bármelyik büntetteknek minősithetô azon büncselekmények miatt, amelyek összefüggésben állnak az államoknak küldöttértesitésben közölt információval. Ezen állam kérésére a föügyész átengedheti az adott személyek elleni nyomozás lefolytatását az államnak, kivéve, ha a Tárgyalás-előkészitő Tanács, a föügyész megkeresésére, a nyomozást engedélyezi." 
megállapitották." A szokásjogi természetú norma tehát vélelmezi a beleegyezés megadását a nem részes fél részéről egészen addig, ameddig a körülményekből más nem következik.

Ami a Nemzetközi Büntetôbírósággal való együttmúködést illeti, a Római Statútum nem ír eló együttmúködési kötelezettséget harmadik államok számára. (Mindemellett megjegyzendő, hogy ezek az államok jogosultak együttmúködni a bírósággal, mi több, az ICC is jogosult erre kifejezetten kérni őket. ${ }^{307}$ ) A statútum 90 . cikke ${ }^{308}$ pedig az együttmúködés során figyelembe veendő, a kiadatásra és átadásra alkalmazandó prioritások kérdését rendezi, melynek hatálya alá szintén bevonja a nem részes államokat.

Az együttmúködés legtöbb vitát generáló és a nemzetközi jogászoknak legtöbb fejtörést okozó pontja minden bizonnyal az immunitás jogintézményével kapcsolatban rajzolódott ki a Római Statútum két rendelkezésének látszólagos normakonfliktusából. Ugyan a részes államok a Római Statútum 27. cikke értelmében mind a személyi, mind a funkcionális immunitást expressis verbis eltörölték, a statútum 98. cikk (1) bekezdése szerint harmadik államok hatóságai elméletben hivatkozhatnak a személyi immunitás szokásjogi normájára. Itt három eset lehetséges, melyek közül az első kettő hipotetikus, az utolsó pedig gyakorlati:

(i) Az első, ha a bíróság olyan elkövetővel szemben jár(na) el, aki nem részes állam állampolgára (egyben az immunitás szempontjából releváns, hivatalos és magas rangú politikai tisztséget tölt be), ám részes állam területén követett el nemzetközi büncselekményt. Ebben az esetben az állampolgárság szerinti állam részérôl a funkcionális immunitás eltörlése, azaz a Római Statútum 27. cikkének az elfogadása hiányzik, és ezen harmadik állam hivatkozhat(na) állampolgára immunitására [12. cikk (2) bekezdés a) pont szerinti eset].

(ii) A második, ha a bíróság olyan elkövetővel szemben jár(na) el, aki nem részes állam állampolgára, ám ezen állam önkéntes alávetési nyilatkozattal elfogadta saját magára nézve a Római Statútum normáit - és ezáltal a Nemzetközi Büntetőbíróság joghatóságát is -, beleértve a 27. cikket, így az immunitás eltörlése e harmadik állam részéről megtörtént [12. cikk (3) bekezdés szerinti eset].

307 Római Statútum 15. cikk (2) bekezdés: „a fơ̈ügyész megvizsgálja a kapott információ valódiságát. Ennek érdekében kiegészitó információt kérhet államoktól, az Egyesült Nemzetek Szervezetének szerveitől, kormányközi vagy nem kormányzati szervezetektól, vagy más, olyan megbizható forrásokból, amelyeket megfelelőnek itél, valamint a Bíróság székhelyén irásbeli vagy szóbeli tanúvallomásokat vehet fel.”; Római Statútum 87. cikk (5) bekezdés: „a) A Bíróság felkérhet olyan államot is, amely a jelen Statútumnak nem részese, hogy a jelen Fejezetnek megfelelöen eseti megállapodás, vagy az állammal kötött nemzetközi szerződés alapján, illetve bármely más megfelelō alapon segítséget nyújtson. b) Amennyiben a Statútumban nem részes állam, amely eseti megállapodást vagy nemzetközi szerzódést kötött a Bírósággal, nem teljesíti a megállapodás vagy a nemzetközi szerzódés szerint benyújtott kérelmeket, a Bíróság értesíti erröl a Részes Államok Közgyúlését, vagy ha a Biztonsági Tanács utalta a Bíróság elé az ügyet, a Biztonsági Tanácsot."

308 A cikk szó szerinti ismertetésétől annak hosszas terjedelme miatt eltekintek, mivel a benne foglaltak a jelen téma szempontjából nem bírnak relevanciával. 
(iii) A harmadik, ha a bíróság olyan elkövetővel szemben jár el, aki nem részes állam állampolgára, és ezen harmadik állam helyzetét a BT utalta a bíróság elé (lásd: Szudán és Líbia). Ez utóbbi eset azért különösen érzékeny, mert az állampolgárság szerinti állam részéről mind a Római Statútumhoz való csatlakozás, mind az önkéntes alávetési nyilatkozat megtétele hiányzik, így a bíróság joghatóság-gyakorlásának közvetlen jogalapja a BT határozata, közvetett módon pedig ENSZ Alapokmányának VII. fejezete [13. cikk b) pont szerinti eset].

Mivel a három lehetőség közül csupán e harmadik bír gyakorlati jelentőséggel, ráadásul számos jogalkalmazási és jogértelmezési kérdést vet fel a Biztonsági Tanács által a Nemzetközi Büntetőbíróság elé vitt helyzetekben, így a későbbiekben majd jelen monográfiában is részletes kibontásra kerül. ${ }^{309}$

\section{A komplementaritás és a Biztonsági Tanács által kezdeményezett eljárások}

\subsection{Problémafelvetés: leszámolás a büntetlenség kultúrájával vs. azállamok büntetőmonopóliumánakigénye}

A Nemzetközi Büntetőbíróság mûködési hatékonyságát bírálók száma az utóbbi időben jelentősen gyarapodott mind a jogtudomány képviselői, mind a praktizáló jogászság körében, mely jelenség okait két fő csapásirány mentén követhetjük végig: ezek közül az egyik, hogy az ICC nem képes az általa kiadott letartóztatási parancsokat végrehajtani; míg a másik, hogy a bíróság nem képes a nemzeti szintű büntetőeljárások megindítását és lefolytatását megfelelően elősegíteni, az állami igazságszolgáltatást „pozitívan” ösztönözni. ${ }^{310}$ A két kritikai irány közül a második szimbiotikus kapcsolatban áll a komplementaritás, azaz a kiegészítő joghatóság jogintézményével, és mivel a BT által az ICC elé vitt helyzetek egyikében a bíróság előtti fó kérdést - többször is - az elfogadhatóság jogintézményének értelmezése képezte, így e kötet hasábjain elkerülhetetlennek mutatkozik a komplementaritás gyakorlati érvényesülésének mélységi elemzése.

A komplementaritás a Nemzetközi Büntetőbíróság létrehozásának és müködésének első számú letéteményese, a Római Statútum leginnovatívabb koncepciója és elfogadá-

309 Mind a 27. cikk, mind a 98. cikk részletes elemzését lásd Az együttmúködés, a nemzetközi elfogatóparancsok végrehajtása és a Biztonsági Tanács által kezdeményezett eljárások címú fejezetben.

310 Robinson, 2015, 323. o. 
sának sine qua nonja, mely a szerződés cikkeiben három helyen ölt testet. ${ }^{311}$ Koncepciójának célja sommásan az, hogy betöltse a büntetlenség pajzsán éktelenkedő réseket, mintegy ultima ratióként szolgálva azokban az esetekben, amikor az állami szintú büntetô igazságszolgáltatás tétlen az emberiség egészét sértő legsúlyosabb bưncselekmények elkövetôinek felelősségre vonásában. A Nemzetközi Büntetőbíróság felállításával megteremtett nemzetközi mechanizmus nem élvez elsőbbséget a nemzeti eljárásokkal szemben, továbbá nemzetközi fellebbviteli fórumnak sem minősül: az ICC a büntetőjogi eszközök sorában mintegy „végső mentsvárként” funkcionál. Kovács Péter a komplementaritás fó céljait (i) a részes államok szuverenitásának és joghatóságának tiszteletben tartásában; (ii) a klasszikus büntetőjogi alapelvek - többek között a ne bis in idem re - és az ICC múkködésének „közelítésében”; valamint (iii) a Nemzetközi Büntetőbíróság ügyterhének észszerú csökkentésében látja, ${ }^{312}$ illetve a fentiek mellett azt is kiemeli, hogy a komplementaritás az állami szintú büntetô igazságszolgáltatás egyfajta nemzetközi bírói ellenőrzését testesíti meg, ${ }^{313}$ mivel a Nemzetközi Büntetőbíróság „beavatkozása” szükségszerú kritikai színezettel bír: ha az ICC színre lép - ami egyrészt azt jelenti, hogy a joghatóság gyakorlásának komplex feltételei fennállnak, másrészt pedig, hogy az ügy elfogadható -, akkor az a nemzeti büntető igazságszolgáltatás súlyos hibáiról, diszfunkciójáról árulkodik.

Bár a komplementaritás elve nóvumként került a bíróság statútumába, a szakirodalom már régebb óta hangsúlyozza, hogy a nemzetközi jog által közvetlenül büntetni rendelt cselekmények miatti felelősségre vonás - csakúgy, mint a belső jogban szankcionált deliktumok esetén - elsődlegesen a nemzeti bíróságok feladata. ${ }^{314}$ Jóllehet a Római Statútum

311 Római Statútum Preambulum (10) bekezdés: „Hangsúlyozva, hogy a jelen Statútummal létrehozott Nemzetközi Büntetôbirróság a nemzeti büntetôjoghatóságokhoz képest kiegészitó jellegü.";

Római Statútum 1. cikk: „Ezennel létrehozzák a Nemzetközi Büntetőbiróságot (a továbbiakban: „Bíróság”), amely állandó intézmény, és a legsúlyosabb nemzetközi büntetteket elkövetôszemélyek fölött gyakorol joghatóságot a jelen Statútum szerint, és a nemzeti büntetố joghatóságokat egészíti ki";

Római Statútum 17. cikk (1) bekezdés: „A Preambulum 10. bekezdésére és az 1. cikkre tekintettel a Bíróság az ügyet elfogadhatatlannak minősiti, ha:

a) Azügyben joghatósággal rendelkezőÁllam nyomozást vagy büntetőeljárást indított, kivéve, ha az Állam nem hajlandó vagy nem képes a nyomozás vagy a büntetôeljárás megfelelő lefolytatására;

b) Azügyben joghatósággal rendelkezőÁllam nyomozást indított, és az Állam úgy határozott, hogy nem indít büntetőeljárást az érintett személy ellen, kivéve, ha a határozatot azért hozták, mert az Állam nem hajlandó vagy nem képes a megfelelóbüntetöeljárás lefolytatására;

c) Az érintett személyt a feljelentés tárgyául szolgáló magatartás miatt már felelósségre vonták, és a Bíróság a 20. cikk 3. bekezdése szerint nem járhatel;

d) Az ügy súlya nem indokolja a Bíróság további eljárását."

312 Kovács, 2017, 346. o.

313 Kovács, 2017, 358. o.

314 Római Statútum Preambulum (6) bekezdés: „Figyelmeztetve arra, hogy minden Állam kötelessége a nemzetközi büntettek elkövetőinek büntetőjogi felelösségre vonása". 
nem kötelezi az államokat a benne foglalt búncselekmények belső jogi szankcionálására, ${ }^{315}$ a komplementer joghatóság miatt többségük a nemzeti jogban való büntetni rendeltség bevezetését választotta annak érdekében, hogy a bíróság esetleges joghatóság-gyakorlását elkerülje. Mivel a statútum büntetőeljárást helyez kilátásba azokban az esetekben, amikor egy állam nem képes vagy nem hajlandó az elkövetőket megbüntetni, az ICC eljárása a nemzeti jogalkotó implementáló tevékenységének elégtelenségéről is súlyos bírálatot fejezhet ki. ${ }^{316}$ Ahogyan azt a Fő̈ugyészi Hivatal egyik hivatalosnak nem minősülő szakértői véleményében korábban összefoglalta, ${ }^{317}$ az állandó nemzetközi büntetóbírói fórum felállításának célja eredendően nem az volt, hogy a jövőben minden egyes, egyébként joghatóságába tartozó ügyben eljárjon. Éppen ellenkezőleg: a nemzetközi büntetőbírói fórum sikerének fokmérője az előtte folyó eljárások csekély száma lenne, tudniillik akkor az állami büntetô igazságszolgáltatás fogaskerekei olajozottan mủködnének. A fent leírt cél teljesülésének pedig alapvetô eszköze a nemzeti büntetőjog - a gyakorlatban fóképp a büntető anyagi jogi kódexek - következetes jogharmonizációja, amely a nemzeti szintû́ eljárások megindításának tárgyi előfeltétele. ${ }^{318}$

A kiegészítő joghatóság statútumba „emelésének” jogpolitikai indokai között első helyen (i) az állami szuverenitás „érintetlensége”, annak tiszteletben tartása áll, mely azért bír kiemelkedő jelentőséggel, mert a büntetőigény monopóliuma érvényesítésének - a vesztfáliai nemzetközi jogrend értelmében ${ }^{319}$ - kizárólagos jogosultjai hagyományosan az államok voltak, akik csak nehézkes kompromisszumok kíséretében voltak hajlandóak engedni e szuverenitás-attribútumukból. A komplementaritás pedig az az aranyközép, mely ehhez a kompromisszumhoz utat talált, és ellensúlyozta a büntetlenség elleni harc melletti elkötelezettséggel szemben a szuverenitás efféle csorbítását azáltal, hogy a nemzetközi mechanizmus kizárólag a statútumban lefektetett kivételes körülmények között léphet életbe. ${ }^{320} \mathrm{~A}$ kiegészítő joghatóság másik két jogpolitikai indoka sokkal inkább praktikus természetú, mint az első. Alkalmazása mellett szól az is, hogy (ii) mivel az ICC kapacitása - mind személyi állománya, mind a rendelkezésre álló anyagi források tekintetében - korlátozott, ügyterhe nyilvánvalóan véges. Harmadsorban (iii) a jogalkotó a komplementaritás Római Statútumba „emelésekor” szem előtt tartotta a helyi hatóságok privilegizált helyzetét, hiszen a nyomozás lefolytatása nemzeti szinten

315 Varga, 2006, 95-98. o.

316 Lásd erröl bővebben: Varga, 2012, 76-86. 0.

317 ICC Office of the Prosecutor: Informal expert paper: The principle of complementarity in practice, \$1, elérhető: https://www.icc-cpi.int/RelatedRecords/CR2009_02250.PDF [Letöltve: 2019. 11. 21.].

318 Varga, 2014, 81-83. o.

319 Hobbs, 2012-2013, 22. o.

320 Okechukwu, 2008, 362. o. 
sokkal eredményesebb a bizonyítási eszközökhöz való közvetlen hozzáférhetőség miatt (ilyenek például a tanúk beidézése, a szükséges okiratok beszerzése vagy a helyszíni szemle lefolytatása). ${ }^{321}$

Annak ellenére, hogy a kiegészítő joghatóság koncepciója a Római Statútumban több helyen felbukkan, a komplementaritás elemeinek fogalma a jogszabályszövegben meglehetősen általános, így a jogalkalmazás során időről időre számos értelmezési kérdés kerül a felszínre. E definíciók kibontásához a vizsgálódónak alapvetően három „segédeszköz” áll rendelkezésére: az első a statútum normaszövegének értelmezése, a második az a - már fentebb is idézett - nem hivatalos szakértői vélemény, melyet a Föügyészi Hivatal 2003-ban adott ki, a harmadik pedig a bíróság, különösképpen a tárgyalás-előkészítő tanácsok - illetve ha az elfogadhatósági kifogásról hozott döntés ellen a kifogástételre jogosultak jogorvoslati jogukkal kívánnak élni, abban az esetben a fellebbviteli tanács joggyakorlata. Utóbbi következetessége kiemelten fontos a bíróság hitelességének körülbástyázása és a politikai elfogultság vádjának elkerülése miatt, ellenben „sziklaszilárd" és konzekvens bírói joggyakorlatról nem minden esetben beszélhetünk, melyet a Szajf al-Iszlám Kadhafi és Abdullah al-Senussi ügyeiben ${ }^{322}$ benyújtott elfogadhatósági kifogásokat elbíráló határozatok szemléletesen példáznak: a bíróság ugyanazon tárgyalás-előkészítő tanácsa a két ügyben hasonló ténybeli alapokból kiindulva teljesen ellentétes következtetésekre jutott. Míg az eljáró kamara Szajf Kadhafi ügyében a Líbia által benyújtott kifogást 2013. május 31-én elutasította, ${ }^{323}$ addig az al-Senussi ügyében benyújtott kifogásnak - mintegy öt hónappal később - 2013. október 11-én helyt adott. ${ }^{324} \mathrm{~A}$ fellebbviteli tanács másodfokon mindkét határozatot helybenhagyta. Al-Senussi ügyével megszületett az ICC fennállásának első sikeres elfogadhatósági kifogása - azaz a vádemelés megtörténte után először került sor arra, hogy a bíróság saját joghatóságának hiányát megállapította -, ugyanakkor a döntés megalapozatlansága miatt mégsem könyvelhetô el a komplementaritás győzedelmes diadalának. ${ }^{325}$ Szajf Kadhafi néhány évvel később maga is elfogadhatósági kifogást nyújtott be az ICC-hez, melyet mind az első-, mind a másodfokú kamara újfent elutasított. Jelen fejezet célja tehát, hogy a líbiai helyzetből kibontakozott ügyek

321 Informal Expert Paper: The Principle of Complementarity in Practice, $\$ 5$.

322 The Prosecutor v. Saif Al-Islam Gaddafi and Abdullah Al-Senussi, ICC-01/11-01/11, Case Information Sheet, elérhető: https://www.icc-cpi.int/CaseInformationSheets/GaddafiEng.pdf [Letöltve: 2020. 05. 15.].

323 Decision on the admissibility of the case against Saif Al-Islam Gaddafi, Prosecutor v. Saif Al-Islam Gaddafi and Abdullah Al-Senussi, ICC-01/11-01/11, ICC Pre-Trial Chamber I, 31 May 2013 (a hivatkozásokban a továbbiakban: Szajf Kadhafi elsö ügye elsőfokú határozat).

324 Decision on the Admissibility of the Case of Abdullah Al-Senussi, Prosecutor v. Saif Al-Islam Gaddafi and Abdullah Al-Senussi, ICC-01/11-01/11-466-Red, ICC Pre-Trial Chamber I, 11 October 2013 (a hivatkozásokban a továbbiakban: Al-Senussi ügye elsőfokú határozat).

325 Tedeschini, 2015, 77. o. 
segítségével rávilágítson arra az esetjogi „törésvonalra”, ami a büntetlenséggel való leszámolás melletti egyetemes igény és az állami szuverenitás, az állami büntetőigény monopóliumának vindikálása között húzódik.

\subsection{Az elfogadhatóság tényállási elemei a Római Statútumban}

A Római Statútum 17. cikke ${ }^{326}$ határozza meg egy ügy ICC előtti elfogadhatóságának a feltételeit. Utóbbi és a komplementaritás nem szinonim fogalmak: a komplementaritás absztrakt értelmében a bíróság végső megoldás a büntetőjog eszközrendszerében, ezzel szemben az elfogadhatóság az a konkrét keretrendszer, melyen keresztül a komplementaritás múködik. ${ }^{327}$ Az elfogadhatóságról szóló rendelkezés szövege azonban jól tükrözi a komplementaritás lényegét: főszabály szerint a nemzeti bíróságnak kell eljárnia („alapeset”), ha pedig ez megfelelően történik, akkor az ügy az ICC elött elfogadhatatlan. Ennek fényében a statútum passzusai az elfogadhatatlanság (inadmissibility) alóli kivételeket sorakoztatják fel, vagyis azokat az eseteket, amikor az ICC mégis eljárhat („kivételes esetek").

Az elfogadhatóság vizsgálatára hivatott teszt kétfázisú és - ahogyan arra a Fő̈ugészi Hivatal a már korábban hivatkozott előzetes vizsgálatokról szóló szakpolitikai dokumentumában rávilágított - empirikus vizsgálatot igényel az eljáró kamara részéről. Ennek egyik

326 Római Statútum 17. cikk: „(1) A Preambulum 10. bekezdésére és az 1. cikkre tekintettel a Bíróság az ügyet elfogadhatatlannak minősiti, ha:

a) Az ügyben joghatósággal rendelkező Állam nyomozást vagy büntetőeljárást indított, kivéve, ha az Állam nem hajlandó vagy nem képes a nyomozás vagy a büntetőeljárás megfelelő lefolytatására;

b) Az ügyben joghatósággal rendelkezôÁllam nyomozást indított, és az Állam úgy határozott, hogy nem indít büntetöeljárást az érintett személy ellen, kivéve, ha a határozatot azért hozták, mert az Állam nem hajlandó vagy nem képes a megfelelő büntetőeljárás lefolytatására;

c) Az érintett személyt a feljelentés tárgyául szolgáló magatartás miatt már felelősségre vonták, és a Bíróság a 20. cikk 3. bekezdése szerint nem járhat el;

d) Az ügy súlya nem indokolja a Bíróság további eljárását.

(2) Adott ügyben az Állam hajlandósága hiányának megállapitása során a Bíróság, tekintettel a nemzetközi jog által elismert tisztességes eljárás alapelveire, mérlegeli, hogy a következő feltételek közül egy vagy több fennáll-e:

a) Az Állam az eljárást azért folytatta vagy folytatja le, illetôleg a határozatot azért hozta, hogy az érintett személyt kivonja a Bíróságjoghatósága alá tartozó, az 5. cikk szerinti büncselekményekért valóbüntetoójogi feleloosségre vonás alól;

b) Az eljárás folyamán indokolatlan késedelem következett be, amely az adott körülmények között összeegyeztethetetlen azérintett személy biróság eléallitásának szándékával;

c) Az eljárást nem függetlenül és pártatlanul folytatták vagy folytatják le, hanem oly módon, hogy adott körülmények között az összeegyeztethetetlen az érintett személy bíróság eléállitásának szándékával.

(3) Annak megállapitása érdekében, hogy adott ügyben az Állam nem képes az eljárás lefolytatására, a Bíróság megvizsgálja, hogy az Állam, saját nemzeti igazságszolgáltatásának teljes vagy súlyos összeomlása vagy hiánya miatt képtelen arra, hogy a vádlottat elfogja, vagy a szükséges bizonyitékokhoz és tanúvallomásokhoz hozzájusson, vagy egyébként az eljárást lefolytassa."

327 Newton, 2001, 52. o. 
eleme annak mérlegelése, hogy az ICC előtti ügyet a nemzeti bíróság érdemben tárgyalta-e vagy tárgyalja-e, illetve érdemi nyomozás folyt-e vagy folyik-e? A másik pedig annak mérlegelése, hogy az ügy megfelel-e a büncselekmények súlyára vonatkozó követelményének (gravity threshold)? A Római Statútum annak kérdését nem rendezi, hogy a teszt két komponense közül melyiket kell a jogalkalmazónak először megvizsgálnia, így a rendelkezés tényállási elemeinek sorrendjéhez igazodva itt is először a komplementaritásteszt, másodszor pedig a súlyossági feltételek képezik az elemzés tárgyát.

(i) A 17. cikk (1) bekezdés a) pont akként rendelkezik, hogy az ICC nem járhat el akkor, ha az ügyben egyébként joghatósággal rendelkező állam nyomozást vagy büntetőeljárást indított - tudniillik az eljárás valamely szakasza jelenleg is folyamatban van -, kivéve, ha az állam nem hajlandó vagy nem képes annak megfelelő lefolytatására (,jelen idő”). Ebben az esetben tehát a helyi eljárás a komplementaritás vizsgálatának idejében éppen zajlik, csak nem felel meg a statútum által támasztott követelményrendszernek - azaz a nemzeti hatóságok „látszattevékenysége” aktiválja az ICC joghatóságát akkor, ha a súlyossági feltétel emellett fennáll.

A Nemzetközi Büntetőbíróság fellebbviteli tanácsa a Katanga-ügyben ${ }^{328}$ rávilágított a 17. cikk (1) bekezdés a) pontja és a tétlenség (inaction) közötti markáns különbségre és az elhatárolás szükségességére, hangsúlyozva, hogy a tétlenség a hajlandóság, illetve a képesség hiányától megkülönböztetendő olyan esetkör, ami szintén a nemzetközi eljárás megindításához vezethet. Azt is hangsúlyozta ugyanakkor, hogy a tétlenség megállapítása nem eredményezi az ICC előtti eljárás automatikus megindítását, mert a bíróság fenntartja magának azt a diszkrecionális jogkört, hogy a statútum által előírt egyéb tényezők figyelembevételével az eljárás folytatását mérlegelje.. ${ }^{329}$ Tehát a fellebbviteli tanács a tétlenséget az eljárási hajlandóság és képesség hiányától egyértelmúen megkülönböztette: utóbbi kettő csak azután vizsgálható ténylegesen, hogy a nemzeti hatóságok az eljárást lefolytatták vagy az folyamatban van, ellenben tétlenség esetén nem is volt, és a vizsgálat pillanatában sem folyik eljárási cselekmény. ${ }^{330}$

(ii) A 17. cikk (1) bekezdés b) pontja tovább szélesíti a kivételek körét arra az esetre, amikor az ügyben joghatósággal rendelkező állam nyomozást indított, és úgy határozott, hogy nem indít büntetőeljárást az érintett személy ellen, kivéve, ha a határozatot azért hozták, mert az állam nem hajlandó vagy nem képes a megfelelő büntetőeljárás lefolytatására („múlt

328 Judgment on the Appeal of Mr. Germain Katanga against the Oral Decision of Trial Chamber II of 12 June 2009 on the Admissibility of the Case, Prosecutor v. Germain Katanga and Mathieu Ngudjolo Chui, ICC01/04-01/07-1497 OA 8, ICC Appeal Chamber, 25 September 2009, \$ 2 (a hivatkozásokban a továbbiakban: Katanga-ügy).

329 Katanga-ügy 85. \$.

330 Katanga-ügy 76. \$. 
idő"). Tehát a komplementaritás vizsgálatakor a nyomozati szak már befejeződött, azonban az állam a büntetőeljárást azért nem indította meg, mert nem volt hajlandó vagy nem volt képes annak megfeleló lefolytatására. Az ICC fellebbviteli tanácsa a Bemba-ügyben ${ }^{331}$ elfogadhatónak találta azt az esetet, amikor a közép-afrikai bíróság szándékosan azért nem folytatta le a nyomozás után a büntetőeljárást az egykori kongói alelnökkel szemben, hogy ügyét a Nemzetközi Büntetóbíróságnak ,átadhassa”.

A fentiekkel áll összefüggésben az ICC fellebbviteli tanácsának a Kenyatta és mások-ügyben ${ }^{332}$ megállapított tétele, miszerint elfogadhatósági kifogás benyújtása esetén az indítványozónak kell bizonyítania, hogy nemzeti szinten zajlott vagy zajlik érdemi eljárási cselekmény, azaz lépéseket tettek annak érdekében, hogy az elkövető felelősségre vonása az adott büncselekmény vonatkozásában megtörténjen (ilyen lépés lehet például a gyanúsítottak vagy tanúk kikérdezése, okirati bizonyítékok és orvosszakértői vélemény beszerzése). Ezeket a nyomozati cselekményeket ugyanakkor valóban meg kell lépnie az állami hatóságoknak, a hajlandóság és készség hangoztatása, a jövőre vonatkozó „ígérgetés” önmagában véve nem elég az ICC előtti eljárás "megakasztásához”. ${ }^{333}$

E helyütt érdemes szólni a fellebbviteli tanács Simone Gbagbo ügyében ${ }^{334}$ tett megállapításáról, ahol a másodfokú tanács az elefántcsontparti eljárást részletekbe menően, konkrétan értékelte. Az ügyben eljáró tárgyalás-előkészítő tanács arról határozott, ${ }^{335}$ hogy az ún. „ugyanazon terhelt, ugyanazon cselekménye” teszt (same person / same conduct test), azaz a tettazonosság tesztjének ${ }^{336}$ értelmében Simone Gbagbo ügye elfogadható az ICC eloott. Elefántcsontpart az elsőfokú határozat ellen fellebbezést nyújtott be arra hivatkozva, hogy a helyi büntetőbíróság az egykori elnök feleségét időközben 20 év szabadságvesztés-büntetésre ítélte, azaz a tárgyalás-előkészítő tanács határozata ténybeli

331 Judgment on the appeal of Mr Jean-Pierre Bemba Gombo against the decision of Trial Chamber III of 24 June 2010 entitled "Decision on the Admissibility and Abuse of Process Challenges", The Prosecutor v. Jean-Pierre Bemba Gombo, ICC-01/05-01/08-962, ICC Appeals Chamber, 23 October 2010, \$\$1, 74-75 (a hivatkozásokban a továbbiakban: Bemba-ügy).

332 Judgment on the appeal of the Republic of Kenya against the decision of Pre-Trial Chamber II of 30 May 2011 entitled "Decision on the Application by the Government of Kenya Challenging the Admissibility of the Case Pursuant to Article 19(2)(b) of the Statute", Prosecutor v. Francis Kirimi Muthaura, Uhuru Muigai Kenyatta and Mohammed Hussein Ali, ICC-01/09-02/11-274, ICC Appeals Chamber, 30 August 2011, \$\$1, 40 (a hivatkozásokban a továbbiakban: Kenyatta és mások-ügy).

333 Kenyatta és mások-ügy 40. \$.

334 Judgment on the appeal of Côte d'Ivoire against the decision of Pre-Trial Chamber I of 11 December 2014 entitled "Decision on Côte d'Ivoire's challenge to the admissibility of the case against Simone Gbagbo", Prosecutor v. Simone Gbagbo, ICC-02/11-01/12 OA, ICC Appeals Chamber, 27 May 2015 (a hivatkozásokban a továbbiakban: Simone Gbagbo ügye).

335 Decision on Côte d'Ivoire's challenge to the admissibility of the case against Simone Gbagbo, Prosecutor v. Simone Gbagbo, ICC-02/11-01/12, ICC Pre-Trial Chamber I, 11 December 2014.

336 Kovács, 2020, 61-72. o. 
értelemben már nem megalapozott. A fellebbviteli tanács előtt tehát az volt a kérdés, hogy elfogadhatóság elleni kifogás esetén az első- és a másodfokú eljárás között született nemzeti bírósági ítélet megalapozza-e a clausula rebus sic stantibus elvének sajátos érvényesülését az eljárásban? ${ }^{337}$ A másodfokú kamara válasza szerint nem, mivel a fellebbezés elbírása során nem vehetők figyelembe azok a tények, amelyek a megtámadott határozat megszületése után következtek be. A „még meg nem történt” tények értékelése a tárgyalás-előkészítő tanács értékelési szempontjain kívül esik, így azok felülvizsgálatára a fellebbviteli tanács sem jogosult. ${ }^{338} \mathrm{~A}$ fellebbezés elbírálása során a bizonyítási teher - tudniillik annak demonstrálása, hogy az ügy elfogadhatatlan az ICC előtt mindig a kifogástevőre hárul, ellenben Elefántcsontpart nem tudta bizonyítani, hogy a gazdasági és állam elleni búncselekmények vizsgálata során a tárgyalás-előkészítő tanács hibát vétett volna. ${ }^{339}$

(iii) Az elfogadhatóság kérdései címú cikk alatt még két másik esetkör szerepel. A 17. cikk (1) bekezdés c) pontja azt az esetet vázolja fel, amikor az érintett személyt a feljelentés tárgyául szolgáló magatartás miatt már felelősségre vonták, és a bíróság a 20. cikk (3) bekezdésében ${ }^{340}$ megfogalmazott kivételek hiányában nem járhat el. Ekkor a bíróságnak le kell folytatnia az „ugyanazon terhelt, ugyanazon cselekménye” tesztet, azaz hogy a nemzeti és a nemzetközi bíróság elôtt álló terhelt ugyanazon személy-e, és hogy ugyanazon büncselekmény miatt folyik-e az eljárás.

$\mathrm{Az}$ „ugyanazon terhelt” kritérium megállapítása különösebb gyakorlati nehézséget nem vet fel, ugyanakkor a tárgyalás-előkészítő tanács visszautasította a Kenyattaés mások-ügyben ${ }^{341}$ Kenya arra irányuló elfogadhatósági kifogását, hogy „a hierarchia azonos fokán álló terhelttel szemben már folyamatban van az ICC elött eljárás”. A kamara kiemelte, hogy az „ugyanazon terhelt" feltételét konkrétan és ténylegesen ugyanarra az egyénre kell vonatkoztatni.

Ellenben az „ugyanazon cselekmény” kritériumának megítélése az esetjogban már sokkal problematikusabb. Szintén a Kenyatta és mások-ügyben a fellebbviteli tanács akként foglalt állást, hogy az „ugyanazon cselekmény” feltételnek tartalmilag az ICC előtti vá-

337 Kovács, 2017, 355. o.

338 Simone Gbagbo ügye 43. \$.

339 Simone Gbagbo ügye 71. \$.

340 Római Statútum 20. cikk (3) bekezdés: „Akit másik bíróság a 6., 7. és 8. cikk értelmében tiltott cselekmény miatt már elitélt, a Bíróság ugyanazon cselekményért csak akkor ítélheti el, ha a másik bíróság eljárása:

a) Azt a célt szolgálta, hogy megvédjék az érintett személyt a Bíróság joghatósága alá tartozó büntett miatti büntetőjogi felelósségre vonás alól; vagy

b) Egyébként nem volt a nemzetközijog által elismert tisztességes eljárás szabályainak megfelelö, független vagy pártatlan eljárás, és úgy folyt le, hogy az adott körülmények között nem felelt meg az érintett személy bíróság elé állítása szándékának".

341 Kenyatta és mások-ügy 50. \$. 
dakkal meg kell egyeznie. ${ }^{342}$ A másodfokú kamara az „ugyanazon terhelt, ugyanazon cselekménye" tesztet kisebb módosítással alkalmazta a gyakorlatban, így találóbb a lefolytatott analízist inkább az "ugyanazon terhelt, tartalmilag ugyanazon cselekménye” tesztként aposztrofálni. Az ítéletet olvasva azonban hiányérzetünk támadhat, mivel a fellebbviteli tanács a továbbiakban nem részletezte, hogy a tartalmi hasonlóságoknak pontosan milyen mértekben kell fennállniuk és mire kell kiterjedniük. E többletfeltétel támasztásával a kamara a normaszövegben lefektetett tesztbe vitatható minőségi flexibilitást csempészett, mely felvetette annak a lehetőségét, hogy egy ügy még akkor is elfogadhatatlannak minősüljön az ICC előtt, ha a nemzeti büntetőeljárás nem teljesen ugyanazon vádpont szerint zajlott, illetve zajlik.

A Főügyészi Hivatal ezzel kapcsolatban Szajf Kadhafi és al-Senussi ügyében ${ }^{343}$ úgy foglalt állást, hogy „bár a »tartalmilag ugyanazon cselekmény« nem követeli meg, hogy a nemzeti büntetóeljárás az ICC elötti ügy valamennyi jellemzőjével azonosságot mutasson, e kritériumot nem lehet akként értelmezni, ami lehetôvé teszi az állam számára, hogy csak a kisebb vétségek esetében folytasson nyomozást" - és ezzel kijátssza az ICC elôtti eljárás lefolytatását. 2016-ban a Főügyészi Hivatal azonban az ügyszelekcióról és fontossági sorrendről szóló szakpolitikai dokumentumábann ${ }^{344}$ - visszautalva a fellebbviteli tanács Ruto és mások-ügyben ${ }^{345}$ tett megállapításaira - megerősítette, hogy az „ugyanazon terhelt, tartalmilag ugyanazon cselekménye” kritériumot kell figyelembe venni az elfogadhatósági teszt lefolytatásakor.

További gyakorlati dilemmaként jelenhet meg a „cselekmény” definiálása. A fellebbviteli kamara a Kenyatta és mások-ügyben úgy foglalt állást, hogy kiindulási pontként a Római Statútum 58. cikke346 alapján kibocsátott letartóztatási parancsban vagy idézésben, illetve a 61. cikk ${ }^{347}$ alapján a tárgyalás-előkészítő tanács által megerősített vádindítvány szerinti cselek-

342 Kenyatta és mások-ügy 38. \$.

343 Prosecution's Response to "Libyan Government's further submissions on issues related to the admissibility of the case against Saif Al-Islam Gaddafi", Prosecutor v. Saif Al-Islam Gaddafi and Abdullah Al-Senussi, ICC01/11-01/11-276-Red2, ICC Pre-Trial Chamber I, 12 February 2013, \$\$ 28-29 (a hivatkozásokban a továbbiakban: Szajf Kadhafiés al-Senussi ügye).

344 ICC Office of the Prosecutor: Policy Paper on Case Selection and Prioritisation, 15 September 2016, elérhető: https://www.icc-cpi.int/itemsDocuments/20160915_OTP-Policy_Case-Selection_Eng.pdf [Letöltve: 2019. 02. 21.].

345 Judgment on the appeal of the Republic of Kenya against the decision of Pre-Trial Chamber II of 30 May 2011 entitled "Decision on the Application by the Government of Kenya Challenging the Admissibility of the Case Pursuant to Article 19(2)(b) of the Statute", Prosecutor v. Francis Kirimi Muthaura, Uhuru Muigai Kenyatta and Mohammed Hussein Ali, ICC-01/09-02/11-274, ICC Appeals Chamber, 30 August 2011.

346 A Római Statútum 58. cikke a letartóztatási parancs vagy idézés tárgyalás-előkészítő tanács általi kibocsátásáról rendelkezik. A szakasz szó szerinti idézésétől e ponton eltekintek, egyrészt annak hossza miatt, másrészt pedig azért, mert a benne foglalt részletszabályok megismerése jelen probléma megértése szempontjából nem releváns.

347 A Római Statútum 61. cikke a vád tárgyalás előtti megerősítéséről rendelkezik, mely a tárgyalás-előkészítő tanács hatáskörébe tartozik. A szakasz szó szerinti idézésétől az 58. cikk kapcsán a lábjegyzetekben megfogalmazott okok miatt ez esetben is eltekintek. 
ményeket kell alapul venni. ${ }^{34}$ Így azt, hogy mi minősül tartalmilag egyazon cselekménynek esetről esetre, az ügy összes körülményét figyelembe véve kell a tárgyalás-elókészítő tanácsnak mérlegelnie. ${ }^{349}$

Mindazonáltal a jogalkalmazóban újabb értelmezési kérdésként merült fel, hogy a "cselekmény" terminológia vizsgálata mind a specifikus ténybeli háttéreseményeket felöleli-e (történeti tényállás), vagy csupán a terhelt vádiratban szereplő búncselekményeit? Azaz meg kell-e a kamarának azt is vizsgálnia, hogy a nemzeti vádhatóság ugyanazon tényállás alapján emelt-e vádat, mint az ICC, vagy a történeti tényállás és a vádpontok közötti kapcsolatot figyelmen kívül hagyhatja? A tárgyalás-előkészítő tanácsok gyakorlata a Laurent Gbagbo ügyében ${ }^{350}$ tett megállapítással cseng össze, miszerint egy ICC előtti ügy „specifikus eseményekből tevődik össze, melyek közben egy vagy több beazonositott gyanúsított a biróság joghatóságába tartozó büntetteket valószinúsíthetően elkövetett". ${ }^{351}$ E megközelítés azt sugallja, hogy a „cselekmény” eseményspecifikus fogalom, melyből pedig következik, hogy a kifogást benyújtó félnek az egyes eseményekre hivatkozva kell bizonyítania a beadványában foglalt vádak azonosságát, tehát e kapcsolat nem hagyható figyelmen kívül.

Ellenben a tárgyalás-elókészítő tanács a fenti megközelítését később kisséárnyalta. Szajf Kadhafi első ügyében ugyanis arra jutott, hogy a bíróság előtti korábbi ügyekkel ellentétben a kibocsátott letartóztatási parancsban szereplő események felsorolása „nem adja vissza a bünösség azon sajátos formáját, mely Kadhafi úrral szemben felmerült", mivel az abban szereplő cselekmények listája „nem kimerító jellegü". ${ }^{352}$ Ebből arra lehet következtetni, hogy a terhelt büncselekményeinek felsorolását elég példákkal illusztrálni, és valamennyi nemzeti hatóság előtti eljárásban szereplő vád releváns lehet az „ugyanazon cselekmény” vizsgálata szempontjából addig, amíg az ICC elôtti eljárás vádpontjaiban szereplő cselekményekkel tartalmilag hasonló bưntetteket fed le, a történeti tényállástól függetlenül. Ez alapján pedig egy állam sikeresen megtámadhatja egy ügy elfogadhatóságát a Nemzetközi Büntetőbíróság előtt arra hivatkozva, hogy hasonló búncselekmények miatt nyomoz - tekintet nélkül arra,

348 Kenyatta és mások-ügy 39. \$

349 Szajf Kadhafiés al-Senussi ügye 34. \$.

350 Decision on the Prosecutor's Application Pursuant to Article 58 for a warrant of arrest against Laurent Koudou Gbagbo, Prosecutor v. Laurent Gbagbo, ICC-02/11-01/11-9-Red, ICC Pre-Trial Chamber III, 30 November 2011, \$10.

351 A tárgyalás-előkészítő tanács más ügyekben is ugyanerre a következtetésre jutott. Lásd: Decision concerning Pre-Trial Chamber I's Decision of 10 February 2006 and the Incorporation of Documents into the Record of the Case against Mr Thomas Lubanga Dyilo, Prosecutor v Thomas Lubanga Dyilo, ICC-01/04-01/06-8-Corr, ICC Pre-Trial Chamber I, 24 February 2006, \$3 (a hivatkozásokban a továbbiakban: Lubanga-ügy); valamint Decision on the Prosecution Application under Article 58(7) of the Statute, Prosecutor v. Ahmad Harun and Ali Kushayb, ICC-02/05-01/07-l-Corr, ICC Pre-Trial Chamber I, 27 April 2007, \$14.

352 Szajf Kadhafiés al-Senussi ̈̈gye 81-83. \$\$. 
hogy e büncselekmények az ICC előtti vádpontokkal adekvát történeti tényállást takarnak vagy sem. Ezzel a kamara a Főügyészi Hivatal meglátásával is szembefordult az eseményspecifikus mérlegelés és az egyes események elkövetési ideje és helye beazonosításának szükségessége kapcsán, mivel elôbbi szerint a „cselekmény” olyan „büntetendő cselekményekre utal, amelyek egy meghatározott helyen és idöben, egy bizonyos eseménysorozat részeként történnek meg".353

(iv) Végül a 17. cikk (1) bekezdés d) pontja kimondja, hogy az ICC akkor is megszünteti az eljárást, ha az ügy súlya nem indokolja, hogy a bíróság tovább folytassa azt. A rendelkezés jogpolitikai indoka mögött az a meglátás húzódik, hogy az ICC egy olyan állandó jellegú büntetőbírói fórum, amely a nemzetközi közösség egészét érintő legsúlyosabb bưntettek szankcionálására hivatott.

A bûntettek „súlyát” a Római Statútum nem definiálja, annak pontos tartalma tûri a vitát. E fogalom kibontására a tárgyalás-előkészítő tanács a Lubanga-ügyben vállalkozott akkor, amikor a terhelt elleni letartóztatási parancsot kibocsátotta 2006-ban. A kamara elsőként felhívta a figyelmet a 17. cikk (1) bekezdésének chapeau-jában szereplő megfogalmazására, mely úgy szól, hogy „a Preambulum 10. bekezdésére és az 1. cikkre tekintettel a Bíróság az ügyet elfogadhatatlannak minősiti, ha [...]", és arra jutott, hogy e rendelkezés eltérést nem engedő norma: ${ }^{354}$ ha a 17. cikkben szereplő esetkörök fennállnak, akkor az ügyet elfogadhatatlannak kell nyilvánítani. (A tanács a Római Statútum angol nyelvú hiteles szövegét alapul véve a „shall” segédige használatát hangsúlyozta.) Tehát az ügy elfogadhatatlan akkor is, ha annak súlya nem indokolja a Nemzetközi Büntetőbíróság további eljárását. 355

A tárgyalás-előkészítő tanács felhívta rá a figyelmet, hogy a súlyosság kritériuma két különböző szakban is értékelendő az ICC eljárása során. Az első az, amikor a Főügyészi Hivatal azt mérlegeli, hogy az előzetes vizsgálat lezárása után egy absztrakt helyzetben kezdeményezzen-e nyomozást, a második pedig az, amikor a nyomozás után azt mérlegeli, hogy egy konkrét ügyben egy konkrét terhelt ellen emeljen-e vádat. ${ }^{356}$

A Lubanga-ügyben eljáró tanács a súlyosság feltételének minőségi tényezőit illetően kifejtette, hogy a büncselekményeknek jellegüket tekintve szisztematikusnak vagy széles körûnek kell lenniük, azaz „izolált” deliktumok nem alapozhatják meg az ICC joghatóságát, míg másik mérlegelési szempontként a bûncselekmények által a nemzetközi közösség egé-

353 Szajf Kadhafiés al-Senussi ügye 78. \$, valamint a határozat 175. és 176. lábjegyzete.

354 Tehát a norma nem diszpozitív, ugyanakkor kógens rendelkezésnek szándékosan nem nevezem a ius cogens sajátos nemzetközi jogi jelentésével való összekeverés elkerülése érdekében.

355 Lubanga-ügy 43. \$.

356 Lubanga-ügy 44. \$. 
szében kiváltott kollektív rémületet emelte ki. ${ }^{357}$ Hozzátette, hogy a súlyossági kritérium statútumba foglalásával a jogalkotó célja az volt, hogy ezzel is erôsítse az ICC előtti eljárások elrettentô hatását. ${ }^{358} \mathrm{~A}$ kamara e helyütt az elrettentő hatás és a generális prevenció tekintetében egyéb faktorok fontosságáról is szólt. Egyrészt fontosnak tartotta annak számbavételét, hogy milyen pozícióban lévő elkövetô ellen kezdeményez eljárást a Főügyészi Hivatal, másrészt pedig, hogy a terhelt mennyiben játszott kulcsszerepet a szisztematikus vagy széles körủ bûncselekmények előfordulásában. Továbbá az állami szereplők, nem állami szereplők, szervezetek és fegyveres csoportok elkövetésben való részvételét emelte ki azzal, hogy az ICC előtt mindig azoknak az egyéneknek kell felelniük, akik főszerepet játszottak a nemzetközi bứntettek eszkalálódásában. ${ }^{359}$

A 17. cikket olvasva kitûnik, hogy valamennyi vizsgálati kritériumot átszövi a „megfelelő" eljárás sztenderdje, amely nem más, mint a nemzeti eljárásokra vonatkoztatott minőségi mérce. ${ }^{360} \mathrm{~A}$ római diplomáciai konferencián felmerült álláspontok ismeretében megállapítható, hogy a részt vevo államok a "hatékony” jelzőt szándékosan nem használták annak túlzott konkrétsága miatt. Ezért esett utóbb a választás inkább a „megfelelol” jelzőre, mely bár széles körû elismerésnek örvendett, ennek használatát is sokan ellenezték pont azért, mert jelentése nagyon absztrakt és túlzottan homályos természetû. ${ }^{361}$

Ráadásul a "megfelelőség” fogalmát a Római Statútum sehol sem definiálja. Az értelmezés tekintetében annyi bizonyos, hogy a „megfelelő” jelentését a „jóhiszeműétől” el kell határolni, mivel attól, hogy egy állam jóhiszemú a büntetőeljárás lefolytatását tekintve, attól még nem biztos, hogy eljárása érdemi is. ${ }^{362}$ Talán Andreas Zimmermann lényeglátása túnik a legmeggyőzőbbnek, amikor azt írja, hogy „egy eljárás akkor megfeleló, ha valóban arra irányul, hogy a terheltet felelösségre vonják, nem pedig egy, a vádlott tényleges büntetőeljárástól való megóvását szolgáló, megrendezett színjáték zajlik birósági díszletek között". ${ }^{63}$

E helyütt továbbá megjegyzendő, hogy a nemzetközi emberi jogi sztenderdeknek - különösen a tisztességes eljáráshoz való jognak - való megfelelés vizsgálata érdekes megítélés alá esik a komplementaritás szempontjából akkor, ha figyelembe vesszük, hogy az ICC nem minősül sem nemzetközi fellebbviteli bírói fórumnak, sem emberi jogi bíróságnak. Utóbbit tükrözi, hogy a római konferencián egyértelmúen elutasították Olaszország arra vonatkozó javaslatát, ${ }^{364}$ hogy a tisztességes eljáráshoz való jog sérelme prima

357 Lubanga-ügy 46. \$.

358 Lubanga-ügy 48. \$.

359 Lubanga-ügy 51-52. \$\$.

360 Holmes, 1999, 49. o.

361 Holmes, 2002, 674. o.

362 Holmes, 2002, 674. o.

363 Zimmermann, 1998, 184. o.

364 Draft Proposal by Italy, UN Doc. A/AC.249/1997/WG.3/IP.4, 5 August 1997. 
facie ok legyen egy ügy ICC elötti elfogadhatóságához ${ }^{365}$ - tehát „pusztán” az alapján nem lehet kimondani az állam hajlandóságának hiányát, hogy a nemzeti büntetőeljárás nem felel meg mindenben a nemzetközi emberi jogi sztenderdeknek. Ha így volna, az ICC a nemzeti büntetőbíróságok fellebbviteli fórumává válna, ami viszont ellentétben állna a komplementaritással és általában véve a Római Statútummal. ${ }^{366} \mathrm{~A}$ többségi szakirodalmi álláspont ${ }^{367}$ ellenben elismeri azt, hogy a vádlott jogainak "durva” megsértése a hajlandóság hiányát jelentheti.

\subsection{Azállami hatóságok hajlandóságának és képességének hiánya a Fö̈̈gyészi Hivatal szakértői véleményében}

Jóllehet az ICC Föügyészi Hivatalának nem hivatalos szakértői véleményei (expert papers) és szakpolitikai dokumentumai (policy papers) normatív erővel nem rendelkeznek, mind a jogtudomány, mind a jogalkalmazás számára hasznos értelmezési segédletként funkcionálnak. Ez alól a komplementaritásról szóló szakértői vélemény sem kivétel, mely az elfogadhatóság elemeinek megértéséhez közelebb vihet minket.

A közjogi méltóságok és állami tisztviselők gyakori érintettsége a nemzetközi bûncselekmények elkövetésében tendenciózusnak mondható, és nem ritka eset, amikor az állam különféle kifinomult módszereket alkalmaz annak érdekében, hogy a politikai elithez tartozó személyek bűnösségét elfedje, bûntetteiket „tisztára mossa”. Ugyanakkor az állami hatóságok hajlandóságának hiánya politikailag érzékeny és bizonyíthatóságát tekintve technikailag nehéz. ${ }^{368} \mathrm{~A}$ fentieket figyelembe véve, a Római Statútum 17. cikk (2) bekezdés a)-c) pontjai szerint az állam hajlandóságának hiánya akkor állapítható meg, (i) ha az állam az eljárást azért folytatta vagy folytatja le, illetőleg az állami bíróság azért hozott határozatot, hogy az érintett személyt kivonja az ICC joghatósága alá tartozó, az 5. cikk szerinti büntettekért való büntetőjogi felelősségre vonás alól [17. cikk (2) bekezdés a) pont]; vagy (ii) ha az eljárás folyamán indokolatlan késedelem következett be, amely az adott körülmények között összeegyeztethetetlen az érintett személy bíróság elé állításának szándékával [17. cikk (2) bekezdés b) pont]; vagy (iii) ha az eljárást nem függetlenül és pártatlanul folytatták vagy folytatják le, hanem oly módon, hogy adott körülmények között az összeegyeztethetetlen az érintett személy bíróság elé állításának szándékával [17. cikk (2) bekezdés c) pont]. Utóbbi

365 Holmes, 1999, 50. o.

366 Fife, 2000, 66-67. o.

367 Mégret és Samson, 2013, 585-586. o.; Tedeschini, 2015, 80. o.

368 Informal expert paper: The principle of complementarity in practice, $\$ 44$. 
az állam részéről egyfajta szándékos és szubjektív döntést feltételez, amely a felelősségre vonás elkerülésére irányul. ${ }^{369}$

A Fő̈gyészi Hivatal szakértői véleménye kitér arra, hogy állami szinten sem okvetlenül egységes az egyes hatóságok hajlandósága. Például lehet, hogy a „bírói ág” hajlandó lenne az eljárást lefolytatni, ám a végrehajtó ág nem, és elképzelhető a „szelektív hajlandóság” is, amikor az állami hatóságok az ellenzéki lázadó csoportok által elkövetett bûncselekmények miatti felelősségre vonásra nyitottak, ám a kormányzathoz kötődő bứncselekmények vonatkozásában már vonakodnak igazságot szolgáltatni. ${ }^{370}$

Megjegyzendő továbbá, hogy a hajlandóság vizsgálatánál eljárási és intézményes tényezôket kell értékelni, nem pedig a lefolytatott eljárás eredményét. Ha például a helyi bíróság úgy dönt, hogy a vádlottat felmenti, még ha észszerúen úgy is tûnik, hogy el kellett volna a terheltet ítélnie, az ICC akkor sem alapozhatja erre a hajlandóság hiányát, ugyanis ez sértené - mintegy predesztinálná - a vádlott tisztességes eljáráshoz való jogát - tudniillik az ártatlanság vélelmét - a nemzetközi eljárás során. ${ }^{371}$

A szakértői véleményből kitûnik, hogy a hajlandóság értékelésekor a hatóságok motivációját nemcsak vélelmezni, hanem bizonyítani is kell, azaz hogy a cél az elkövető büntetőjogi felelősségre vonástól való megóvása. Utóbbira a politikai befolyásra, szándékos akadályoztatásra és késedelemre vonatkozó bizonyítékokból lehet következtetni, továbbá az olyan „intézményes tökéletlenségekből", mint a nyomozó hatóság, az ügyészség és a bíróság politikai alárendeltsége, valamint olyan eljárási szabálytalanságokból, melyek az érdemi nyomozás és büntetőeljárás hiányára utalnak. Értelemszerúen e faktorok kevert elegye is a hajlandóság hiányára enged asszociálni. ${ }^{372}$ (Utóbbi elemet a Föügyészi Hivatal külön hangsúlyozta a BT-nek készített egyik jelentésében, külön kiemelve, hogy egy állam elsődlegesen akkor nem hajlandó a nyomozás vagy a büntetőeljárás lefolytatására, ha magatartása azt célozza, hogy a gyanúsítottat a felelősségre vonástól megóvja.) ${ }^{373}$

Végül, de nem utolsósorban a Föügyészi Hivatal véleményének 4. számú mellékletében találhatunk fogódzókat a hajlandóság hiányának feltárásához. Ami az elkövető büntetőjogi felelősségre vonástól való megóvását illeti, a vélemény szerint e célzat a „bennfentesek" vallomásaival, írásbeli dokumentumokkal (például hatályos jogszabályokkal, parancsokkal, amnesztiáról szóló rendeletekkel, utasításokkal, magánlevelezéssel) bizonyítható,

369 Saxum, 2009-2010, 3. o.

370 Informal expert paper: The principle of complementarity in practice, $\$ 45$.

371 Informal expert paper: The principle of complementarity in practice, $\$ 46$.

372 Informal expert paper: The principle of complementarity in practice, $\$ 47$.

373 Report of the Prosecutor on Darfur to the UN Security Council: Highlights and Analysis, Citizens for Global Solutions, 2005, \$2, elérhető: https://globalsolutions.org/search/node/darfur [Letöltve: 2016. 06. 12.]. 
csakúgy, mint szakértők vallomásaival, akik tanúbizonyságot tudnak tenni a rendszer átpolitizáltságáról.

Az állami hatóságok képességét illetően a Fő̈̈gyészi Hivatal szakértői véleménye a késedelem tekintetében leszögezi, hogy valamennyi eljárási szakaszban azt kell megvizsgálni, hogy az arányban áll-e a más - hasonlóan összetett - ügyekben szokásosnak mondható késedelem időtartamával, hogy igazolható-e, és hogy összeegyeztethető-e az elkövető feleloosségre vonásának szándékával. A függetlenség magyarázata során a szakértői vélemény az ügyészség és a bíróság autonómiáját, az ügyészek és bírák kinevezésének menetét, a kormányzó hatalom természetét, a nyomozásba és büntetőeljárásba való politikai befolyás mértékét, valamint a bírósági ítéletek „előre eldöntött” jellegét emeli ki. Az utolsó értékelésre számot tartó elem a pártatlanság fogalma, melynek kapcsán a Főügyészi Hivatal véleménye a gyanúsítottak és az eljáró hatóságok között esetlegesen előforduló és elfogultságot megalapozó tényezőkre hívja fel a figyelmet. A 4. számú melléklet olyan körülményeket sorakoztat fel, amelyek önmagukban nem alapozzák meg a hajlandóság hiányát, azonban a fentebb felsorolt tényezőkhöz társulva már számításba veendők. Így például, ha a hatóságok a bűncselekmények elkövetéséről tudva semmiféle eljárást nem kezdeményeznek, vagy ha sok eljárás indult, ám észszerủ időn belül egyik sem fejeződött be, vagy ha a nyomozás maga nem érdemi, vagy ha az eljárás során felhasznált bizonyítékok nem megfelelőek, vagy ha a nyomozók, ügyészek, bírák merőben eltérnek az ügyben a szokásos gyakorlattól. ${ }^{374}$

Az állam hajlandóságának hiányával összehasonlítva az eljárás lefolytatására vonatkozó képesség hiányának megállapítása némileg egyszerúbbnek bizonyul az ICC szemszögéből nézve, mivel ezt a kritériumot több objektív tényező határozza meg. A Római Statútum 17. cikk (3) bekezdése szerint: „Amikor adott ügyben [a Bíróság] megállapítja, hogy az Állam nem hajlandó az eljárás lefolytatására, a Bíróság megvizsgálja, hogy az Állam, saját nemzeti igazságszolgáltatásának teljes vagy súlyos összeomlása vagy hiánya miatt képtelen arra, hogy a vádlottat elfogja, vagy a szükséges bizonyitékokhozés tanúvallomásokhoz hozzájusson, vagy egyébként az eljárást lefolytassa”. A fentieket summázva tehát az állam akkor képtelen a büntetőeljárás lefolytatására, ha bírósági rendszere összeomlott vagy elérhetetlen.

Azonban azt a statútum nem tisztázza, hogy az állam tehetetlenségének megállapítására konkrétan milyen eljárásban és milyen tényezők figyelembevételével kerüljön sor. A már fentebb is említett jelentésben a Föügyészi Hivatal kifejtette, hogy az állam az eljárás lefolytatására akkor nem képes, ha jogrendszere „nem létezik”, vagy „átszövi” a társadalmi

374 Informal expert paper: The principle of complementarity in practice, Annex 4: List of indicia of unwillingness or inability to genuinely carry out proceedings. 
elégedetlenség, a háború, illetve a korrupció. ${ }^{375}$ Ezáltal az állam tétlensége az emberi erőforrás és intézmények hiányából ered, amikor is az állam jogrendszere, illetôleg közigazgatása teljesen összeomlott. ${ }^{376}$

A Fơügyészi Hivatal nem hivatalos szakértői véleményének 4. számú melléklete az eljáró hatóságok képességének hiányára utaló tényezőket is felsorakoztat, melyek a szükséges emberi erőforrások (nyomozók, ügyészek, bírák) hiánya, a bírósági infrastruktúra hiánya, a megfelelő büntető anyagi vagy eljárásjogi jogszabályok hiánya, a bírói igazságszolgáltatáshoz való hozzáférés hiánya, továbbá amnesztia és mentelmi jog indokolatlan alkalmazása.

\subsection{Az elfogadhatóság megtámadása a Római Statútum 19. cikke alapján}

Az ICC csakúgy, mint a nemzeti hatóságok, valamennyi előtte lévő ügyben köteles saját joghatóságát ex offico vizsgálni, mely kötelezettség gyakorlati címzettje a Föügyészi Hivatal és az adott ügyben kompetens tárgyalás-előkészítő tanács. A Római Statútum 19. cikk (2) bekezdés a)-c) pontjai ${ }^{377}$ ezzel összhangban lehetőséget biztosítanak arra, hogy az arra jogosultak a tárgyalás-elókészítő szakban joghatósági vagy elfogadhatósági kifogást nyújtsanak be a bírósághoz.

Kifogást tehet (i) a vádlott vagy az a személy, akivel szemben letartóztatási parancsot, illetve az 58. cikk ${ }^{378}$ szerint idézést bocsátottak ki; (ii) az ügyben joghatósággal

375 Report of the Prosecutor on Darfur to the UN Security Council: Highlights and Analysis, Citizens for Global Solutions, $\$ 6$.

376 Saxum, 2009-2010, 4. o.

377 Római Statútum 19. cikk (2) bekezdés: „Az ügy elfogadhatóságáta 17. cikkben meghatározott indokkal vagy a Bíróság joghatóságát kifogással megtámadhatja:

a) A vádlott, vagy az a személy, akivel szemben elfogatóparancsot, illetve az 58. cikk szerint idézést bocsátottak ki;

b) Az ügyben joghatósággal rendelkezôÁllam, azzal az indokkal, hogy az ügyben nyomozást folytat vagy folytatott, illetöleg az ügyben a büntetöeljárás lefolytatása folyamatban van, vagy azt lefolytatták; vagy

c) Az az Állam, amelytől a 12. cikk értelmében a joghatóság elfogadását be kell szerezni."

378 Római Statútum 58. cikk: „(1) A tárgyalás-elókészitő tanács a fơ̈ügyész megkeresésére, a nyomozás megkezdése után bármikor kibocsáthat elfogatóparancsot, ha a föügyész által benyújtott kérelem és bizonyitékok vagy más információk megvizsgálása után meggyőzőött arról, hogy:

a) Alapos gyanú áll fenn arra nézve, hogy az adott személy a Bíróság joghatósága alá tartozó büncselekményt követett el;és

b) A személy letartóztatása szükségesnek látszik annak biztositása érdekében, hogy:

(i) A személy a tárgyaláson megjelenjen,

(ii) A személy ne akadályozza vagy veszélyeztesse a nyomozást vagy a bírósági eljárást, vagy

(iii) Ha helyzet úgy kivánja, megakadályozzák, hogy az adott személy folytassa a büncselekmény vagy olyan kapcsolódó büncselekmény elkövetését, amely a Bíróság joghatósága alá tartozik, és ugyanazon körülményekből származik.

(2) A fö̈̈̈yész megkeresése a következő a da tokat tartalmazza:

a) A személy nevétés más fontos személyi adatait;

b) A személy által feltehetően elkövetett, és a Bíróság joghatósága alá tartozó büncselekmények pontos tényállását; 
rendelkezó állam azzal az indokkal, hogy az ügyben nyomozást folytat vagy folytatott, illetőleg az ügyben a büntetőeljárás lefolytatása folyamatban van, vagy azt lefolytatták; vagy (iii) az az állam, amelytől a 12. cikk³79 értelmében a joghatóság elfogadását be kell szerezni.

A 19. cikk eredetileg a joghatóság körül keletkező esetleges jogviták eldöntése érdekében került bele a Római Statútumba, ellenben mára már az állami szuverenitásért vívott csaták látens fegyverévé avanzsálódott. ${ }^{380}$ E rendelkezés szerinti eljárás résztvevői az ügyészség, a védők és az áldozatok képviselői lehetnek, ám az államok részvétele némileg vitatott azokban az esetekben, amikor valamely másik fél indítványozta az eljárást. A tárgyalás-előkészítő tanács a Kenyatta és mások-ügyben kimondta, hogy ha a védelem kezdeményezi az elfogadhatósági eljárást, akkor abban az állam nem vehet részt. Utóbbi csak akkor lehet perbeli fél a 19. cikk szerinti eljárásban, ha abban való érdekeltsége az ICC statútumából egyértelmúen következik, így például a 19. cikk (2) bekezdés b) pontja szerint maga nyújtott be kifogást.

c) Azon tények rövid leírását, amelyekrōl azt állítják, hogy amelyekre a feltételezett bûncselekményeket alapozzák;

d) Azon bizonyitékok és egyéb információk összefoglalását, amelyek alátámasztják annak az alapos gyanúját, hogy az adott személy a büncselekményt elkövette; és

e) Azoknak az okoknak az ismertetését, amelyek miatt a fö̈̈gyész szükségesnek tartja a személy letartóztatását.

(3) Az elfogatóparancs tartalmazza:

a) A személy nevétés más fontos személyi adatait;

b) A Bíróság joghatósága alá tartozó azon büncselekmények pontos tényállását, amelyek miatt a személy letartóztatását kérik;

c) Azon tények rövid leírását, amelyek a feltételezett büncselekmények részét képezik.

(4) Az elfogatóparancs addig marad hatályban, amig a Bíróság másképp nem határoz.

(5) Az elfogatóparancs alapján a Bíróság kérheti a személynek a IX. Fejezet szerinti előzetes letartóztatását, vagy letartóztatását és átadását.

(6) A föügyész kérheti a tárgyalás-előkészítő tanácsot, hogy módositsa az elfogatóparancsot a benne foglalt büncselekmények minősitésének megváltoztatásával vagy új büncselekményekkel való kiegészítésével. A tárgyalás-előkészítő tanács módosítja az elfogatóparancsot, ha alapos gyanú áll fenn arra nézve, hogy a személy elkövette a megváltoztatott minősitésü büncselekményeket, illetve a további büncselekményeket.

(7) Az elfogatóparancs helyett a fö̈̈gyész a tárgyalás-elókészitoó tanácstól idézés kibocsátását is kérheti. Ha a tárgyalás-előkészitő tanács meggyőződött arról, hogy alapos gyanú áll fenn arra nézve, hogy az adott személy elkövette a terhére rótt büncselekményt, és az idézés elegendő annak biztosítására, hogy a személy megjelenjék a Bíróság előtt, idézést bocsát ki, (a fogva tartáson kívüli) szabadságot korlátozó feltételekkel vagy ezek nélkül, ha arról a nemzeti jog is rendelkezik. Az idézés a következő adatokat tartalmazza:

a) Azérintett személy nevétés az azonositásához célszerü minden más adatot;

b) Azt a pontos időpontot, amikor az érintett személynek meg kell jelennie;

c) Annak a Bíróság joghatósága alá tartozó büncselekménynek a pontos tényállását, melynek elkövetésével az adott személyt gyanúsítják; és

d) Azon tények rövid leírását, amelyek a feltételezett büncselekmény részét képezik. Az idézést az adott személynek kézbesitik."

379 Római Statútum 12. cikk (3) bekezdés: „Ha Bíróság joghatóságának olyan Állam általi elfogadása szükséges a 2 . bekezdés szerinti célból, amely a jelen Statútumban nem Részes Állam, az adott Állam a hivatalvezetőhöz benyújtott nyilatkozattal elfogadhatja az adott büncselekmény tekintetében a Bíróság joghatóságát. Az elfogadó Állam késedelem és kivétel nélkül a IX. Fejezetben meghatározottak szerint együttmüködik a Bírósággal."

380 Stahn, 2015, 328. o. 
A bíróság tárgyalás-előkészítő tanácsa e következtetéssel párhuzamosan megjegyezte, hogy ez nem jelenti egyben azt, hogy az eljárás során a jövőben az állam érdekeltsége egyáltalán nem merülhet fel..$^{381}$

\subsubsection{Esetjogi kontrasztok: Líbia elfogadhatósági kifogásai}

A Főügyészi Hivatal a komplementaritás gyakorlati értelmezéséről szóló szakértői véleményében külön kitér a kiegészítő joghatóság érvényesülésére a Biztonsági Tanács által a Nemzetközi Büntetôbíróság elé utalt szituációkban. Ebben kimondja, hogy a komplementaritás „ugyanolyan” szerepet játszik ezekben a helyzetekben, mint a részes államok által kezdeményezett és a proprio motu indított eljárásokban, ugyanakkor e megállapítás némi árnyalást igényel: a komplementaritás általános érvényesülése ugyanis nem jelent egyet azzal, hogy a BT az általa indított eljárásokban az elfogadhatóság előzetes vizsgálatára jogosult, ${ }^{382}$ mivel ez a Fő̈ugyészi Hivatal és a tárgyalás-előkészítő tanács kizárólagos hatáskörébe tartozik. ${ }^{383}$ Ezért a komplementaritás szerepe a Biztonsági Tanács által kezdeményezett eljárásokban - azok „dinamikai” különbségei miatt - rendkívül sajátos, különös tekintettel az időtényezőre.

Carsten Stahn emlékeztet rá, hogy az idő rövidsége okán az ICC kiegészítő joghatósági feltételeinek maradéktalan fennállása e szituációkban a legvalószínúbb annak ellenére, hogy természetesen ekkor is „ugyanúgy” lehetősége van arra a (poszt)konfliktusos államoknak, hogy érdemi eljárást indítsanak vagy folytassanak - csak éppen ennek megvalósítására nagyon kevés idő áll rendelkezésükre. ${ }^{384} \mathrm{~A}$ Biztonsági Tanács a dárfúri helyzetet 2005. március 31-én utalta az ICC elé, majd a Fő̈ugyészi Hivatal a nyomozás megindításáról két hónappal később határozott. Ugyanerre Líbia öt napot kapott: a BT 1970. (2011) - egyhangúan és rekordgyorsasággal elfogadott - határozata 2011. február 26-án látott napvilágot, Luis Moreno-Ocampo március 3-án bejelentette az előzetes vizsgálat lezárását és a nyomozás megindítását, három hónappal később pedig a tárgyalás-előkészítő tanács kibocsátotta a terheltek elleni letartóztatási parancsokat. Ezen „fénysebességư” eljárási cselekményekkel a Főügyészi Hivatal minden bizonnyal a büntetlenség elleni harc melletti elkötelezettségét és arra gyakorolt hatását próbálta maximalizálni, ${ }^{385}$ ellenben ehelyett inkább arra világított rá, hogy

381 Kenyatta és mások-ügy 9. \$.

382 A komplementaritást az előzetes vizsgálat alá vont helyzetek esetén még nem, csak a konkrét esetek sajátosságait figyelembe véve lehet vizsgálni. Utóbbit egyrészt a Főügyészi Hivatal teszi meg a vádemelés alkalmával, másrészt a tárgyalás-előkészítő tanács a vád megerősítése, illetve a fellebbviteli tanács az elfogadhatósági kifogások elbírálása során.

383 Informal expert paper: The principle of complementarity in practice, $\$ \$ 68-70$.

384 Stahn, 2015, 309. o.

385 Hobbs, 2012-2013, 22. o. 
a komplementaritás kibontakozását a BT által kezdeményezett eljárásokban az időtényező meggátolhatja.

Ennek ellenére a bírói gyakorlat számos értelmezési hozadékkal járult hozzá a komplementaritás kibontásához - mely elv lényegében véve meghatározza az ICC szerepét és helyét a nemzetközi jogrendben - a Biztonsági Tanács által kezdeményezett eljárásokban is, különös tekintettel Szajf Kadhafi ${ }^{386}$ és Abdullah al-Senussi ügyeire. ${ }^{387}$ Így a továbbiakban a líbiai helyzet segítségével kerül bemutatásra, hogy milyen további gyakorlati kérdések kerültek felszínre a komplementaritással kapcsolatban a BT által az ICC elé vitt helyzetekben. A Szajf Kadhafi és Abdullah al-Senussi ügyeiben hozott határozatok indokolását a tárgyalás-előkészítő tanács a Római Statútum 17. cikke mentén haladva két logikai láncra fúzte fel: az állam eljárási képességének hiányát elemezte a 17. cikk (3) bekezdése tükrében; valamint azt vizsgálta meg, hogy a tisztességes eljáráshoz való jog sérelme milyen mértekben veendő figyelembe az eljárási hajlandóság hiányának vizsgálata során. Utóbbiak fényében ugyanaz az eljáró kamara a két ügyben eltérő következtetésre jutott: az al-Senussi-ügyben Líbia elfogadhatósági kifogásának helyt adott és az eljárást megszüntette, míg Szajf Kadhafi első ügyében az elfogadhatósági kifogást elutasította. A monográfia soron következő része tehát e két határozat elemzésére tesz kísérletet, majd rátér a Kadhafi második ügyében ismételten elutasított elfogadhatósági kifogásra.

7.4.1.1. Szajf Kadhafi első ügyének elfogadhatósága a tárgyalás-előkészítő tanács határozata tükrében

Líbia a Római Statútum 19. cikk (2) bekezdés a) pontja alapján elfogadhatósági kifogást nyújtott be Szajf Kadhafi ügyében a Nemzetközi Büntetőbírósághoz 2012. május 1-jén arra hivatkozva, hogy a nemzeti igazságszolgáltatási szervek aktívan nyomoznak az ügyében. ${ }^{38}$ A tárgyalás-előkészítő tanács a kifogást elbíráló határozatot 2013. május 31-én hozta meg, melyben megállapította, hogy Szajf al-Iszlám Kadhafi ügye389 elfogadható az ICC előtt, Líbia kifogását pedig elutasította.

A tárgyalás-előkészítő tanács elsőfokú határozata a fellebbviteli tanács addigi joggyakorlatával összhangban megerősítette, hogy bár a komplementaritás elvének tükrében a nemzeti büntetőeljárások élveznek preferenciát, ez nem mentesíti a kifogást tevő államot

386 Az ügyről bővebben lásd a Nemzetközi Büntetőbíróság honlapját: https://www.icc-cpi.int/libya/gaddafi [Letöltve: 2019. 12. 09.].

387 Az ügyről bővebben lásd a Nemzetközi Büntetőbíróság honlapját: https://www.icc-cpi.int/Pages/item.aspx?name $=$ pr1034\&ln=en [Letöltve: 2019 . 12. 09.].

388 Application on behalf of the Government of Libya pursuant to Article 19 of the ICC Statute, The Prosecutor v. Saif Al-Islam Gaddafi and Abdullah Al-Senussi, ICC-01/11-01/11-130-RedICC Pre-Trial Chamber I, 1 May 2012. 389 Szajf Kadhafi ügyeinek elemzését lásd bővebben: Kovács, 2020, 72-76. 
a bizonyítási teher alól. Mivel Szajf Kadhafi ügyében pontosan ez volt a helyzet, így Líbiának kellett (volna) azt bebizonyítania, hogy konkrét lépéseket tesz az egykori de facto miniszterelnök megfelelő felelősségre vonásának irányába. ${ }^{390}$

Az ügyben elsőként megválaszolandó kérdés az volt, hogy a líbiai és az ICC előtti eljárás „ugyanazon cselekmény” miatt folyik-e? A tárgyalás-előkészítő tanács - szintén a bíróság korábbi esetjoga fényében - abból indult ki, hogy az analízis során a történeti tényállás szerinti cselekményeket és nem azok büntetőjogi minősítését kell alapul venni. Líbia büntető törvénykönyve az emberiesség elleni büncselekményeket a vádban szereplő bưntettek elkövetésének idején nem szankcionálta, ám ez a bíróság értékelése szerint nem jelentette azt per se, hogy más minősítéssel nem történhetett volna meg ugyanazon történeti tényállás alapján a megfelelő felelősségre vonás. Sôt az eljáró tanács rávilágított arra, hogy az sem szükséges az ügy elfogadhatatlanságának megállapításához, hogy a nemzeti eljárás valamennyi letartóztatási parancsban szereplő vádpontot felölelje: elég, ha a cselekmények ugyanazon „eseménysorozat részeként történnek meg”. ${ }^{391}$ A tárgyalás-előkészítő tanács végső következtetése azt volt, hogy bár valóban történtek "előremutató lépések" Szajf Kadhafi felelősségre vonásának irányába, Líbia nem tudta bizonyítani, hogy a helyi hatóságok „ugyanazon cselekmények” okán folytatnak eljárást, mint az ICC.

Ahogyan azt a fellebbviteli tanács 2009-ben a Katanga-ügyben megfogalmazta, az eljárási hajlandóság és képesség csak akkor vizsgálható, ha a bíróság meggyőződött róla, hogy a nemzeti és a nemzetközi búnvádi eljárás tárgyát „ugyanazon cselekmények” képezik, máskülönben - az eljáró másodfokú tanácsot szó szerint idézve - „a ló elé fognánk be a szekeret”. ${ }^{392}$ Ezzel szemben a tárgyalás-előkészítő tanács figyelme jelen ügyben azután szegeződött az eljárási képesség hiányára, hogy a tettazonosság kritériumának nemteljesülését már megállapította. Az elsőfokú kamara végül kimondta Líbia eljárási képességének hiányát, nyitva hagyva a kérdést, hogy vajon önmagában az „ugyanazon személy, ugyanazon cselekménye” tesztre alapozva is az ügy elfogadhatóságáról határozott volna? Az analízis sorrendje és logikai íve disszonáns, tekintettel arra, hogy a tárgyalás-előkészítő tanács azt is kimondta, hogy az eljárási hajlandóságot azért nem vizsgálta meg, mert az eljárási képesség hiányának megállapításával az ügy elfogadhatósága már úgyis eldőlt.. ${ }^{393}$

A vizsgálat kronológiája tehát a Katanga-ügyben megállapított „lépcsőzetes” sorrend szerint logikus: (i) először az „ugyanazon személy, ugyanazon cselekménye” tesztre érdemes 
fókuszálni, ha annak eredménye pozitív, akkor (ii) az eljárási képességre, ha pedig annak is pozitív a megítélése, akkor következhet (iii) az eljárási hajlandóság értékelése. Megállapítható tehát, hogy a leginkább objektív faktor irányából a leginkább szubjektív faktor irányába észszerủ a vizsgálatot lefolytatni.

Fontos azonban megjegyezni, hogy a gyakorlatban e szempontokat nem lehet vegytisztán, egymástól elkülönítve kezelni: az „ugyanazon személy, ugyanazon cselekménye” teszt kiértékelése során okvetlenül szükséges bizonyos mértékben a hatóságok eljárási hajlandóságának - mintegy „járulékos” - figyelembevétele is, melyre a határozat azon sora enged következtetni, hogy „a benyújtott bizonyitékok kielégito” mértékben demonstrálták, hogy a líbiai hatóságok számos elöremutató lépést tettek Kadhafi úr büntetôjogi felelősségre vonásának irányába”394 (mely megállapítás egyébiránt nehezen egyeztethető össze az eljárási hajlandóság hiányával).

Ami az eljárási képesség részletes elemzését illeti, az elsőfokon eljáró kamara az állami jogrendszerből, annak büntető anyagi és eljárásjogi jogintézményeiből indult ki. A líbiai büntető eljárásjogi kódex rendelkezései közül a 106. \$-t emelte ki, mely előírja, hogy a terheltnek a nyomozati szakasztól kezdődően joga van a védőhöz - mind akkor, amikor az ügyészség kihallgatja, mind akkor, amikor a tanúkkal szembesítik. ${ }^{395}$ Líbia beadványában arra hivatkozott, hogy az igazságügyi minisztérium felvette a kapcsolatot az abban illetékes szervekkel azért, hogy SzajfKadhafi számára megfelelő jogi képviseletet biztosíthassanak, ám a kifogás benyújtásáig - a magas fokú biztonsági kockázat miatt - nem tudtak még védőt kirendelni. Azt is kiemelte, hogy Kadhafi kihallgatása során a jogi képviselő jelenlétének nélkülözésével nem követtek el jogsértést, mert utóbbi csak akkor jogellenes, ha a kirendelés már korábban megtörtént. ${ }^{396}$

Ezen érvek dacára a tárgyalás-előkészítő tanács a Római Statútum 17. cikk (3) bekezdése értelmében megállapította, hogy a nemzeti igazságszolgáltatási rendszer „elérhetetlen" a terhelt számára, mivel a líbiai hatóságok sem a vádlottat, sem a tanúkat nem voltak képesek elóállítani. ${ }^{397}$ Felhívta rá a figyelmet, hogy az elfogadhatóság vizsgálatakor Szajf Kadhafit egy zintani irreguláris milícia tartotta fogva, akit a központi kormányzat erőfeszítéseinek dacára sem sikerült kézre keríteni, és mivel a líbiai büntető eljárásjog alapján in absentia tárgyaláson a vádlott bủnösségét megállapítani nem lehet, az eljárás lefolytatása sem lehetséges. ${ }^{398}$

394 Szajf Kadhafi elsö ügye elsőfokú határozat 52-54. \$\$.

395 Szajf Kadhafi első ügye elsôfokú határozat 201-202. \$\$.

396 Tedeschini, 2013, 84. o.

397 Szajf Kadhafi elsö ügye elsôfokú határozat 205. \$.

398 Szajf Kadhafi első ügye elsőfokú határozat 206-208. \$\$. 
A határozatot összegezve elmondható, hogy a tárgyalás-előkészítő tanács anélkül mondta ki a líbiai hatóságok képtelenségét a megfeleló eljárás lefolytatása tekintetében, hogy az elfogadhatósági teszt hajlandóságra vonatkozó kérdéseit érdemben megvizsgálta volna. ${ }^{399}$ Abban azonban a korábbi határozatokhoz hú maradt, hogy az elfogadhatóság vizsgálatakor a kifogás elbírálásának pillanatában megtörtént tényeket vette alapul, kizárva az értékelésből a jövőbeni eljárásokra vonatkozó ígéreteket. ${ }^{400}$

7.4.1.2. Abdullah al-Senussi ügyének elfogadhatatlansága a tárgyalás-előkészítő tanács határozata tükrében

Líbia a Római Statútum 19. cikk (2) bekezdés b) pontja alapján elfogadhatósági kifogást nyújtott be al-Senussi ügyében is a Nemzetközi Büntetőbírósághoz 2013. április 2-án. Az ügyben eljáró tárgyalás-előkészítő tanács a kifogást elbíráló határozatot 2013. október 11-én hozta meg, melyben a Kadhafi-ügyben lefolytatott vizsgálatot megismételve eltérő jogi következtetéseket vont le, és Líbia kifogásának helyt adva al-Senussi ügyét elfogadhatatlannak nyilvánította.

Az elsőfokú kamara az ügy elfogadhatóságát a Katanga-ügyben korábban megvont kontúrok szerint vizsgálta meg, így elsőként a tettazonosság tesztjét folytatta le. Ennek kapcsán Líbia beadványában azzal érvelt, hogy az elfogadhatóság vizsgálatánál az „ügy” fogalmát kiterjesztően kellene az ICC-nek értelmeznie azért, hogy a helyi ügyészség autonómiája és diszkrecionális jogköre bizonyos mértékben megmaradhasson a vádban foglalt cselekmények meghatározása felett. ${ }^{401}$

Az eljáró bírói tanács amellett foglalt állást, hogy a letartóztatási parancsban foglalt bủncselekmények nem a vádlott által elkövetett büntettek egyedi megnyilvánulásai (unique manifestations) voltak, hanem csupán példák nem kimerítő jellegú illusztratív listája, így a letartóztatási parancsban foglaltakat az „ugyanazon cselekmény” kritériumának értékelésekor összehasonlítási alapként figyelembe venni lehet ugyan, de nem kötelező. Ennek alapján - a Kadhafi-ügyben megállapított összehasonlítási alapot erodálva - a tárgyalás-elókészítő tanács megállapította, hogy az al-Senussi ügyében indított helyi eljárásban felhozott vádak „tartalmilag ugyanazon cselekményeket” ölelik fel, mint a Föügyészi Hivatal által emelt vádpontok (számos civil és politikai disszidens megölése Bengáziban 2011. február 15. és 20. között, mely mögött a líbiai állam rendszerellenes forradalom leverésére irányuló szisztematikus politikája rejlett). ${ }^{402}$ 
Ami az eljárási hajlandóság és képesség hiányát illeti, a tárgyalás-elókészítő tanács - igazodva a Líbia beadványában foglaltakhoz - jelen ügyben e két kategóriát együttesen vizsgálta. ${ }^{403} \mathrm{~A}$ terhelt eloállítása al-Senussi esetében - Kadhafival ellentétben - megvalósult, tekintve, hogy a kifogás elbírálásának pillanatában a vádlott a líbiai hatóságok ôrizetében volt. ${ }^{404} \mathrm{~A}$ kamara elutasította a védelem arra vonatkozó érvét, miszerint a központi hatóságok nem gyakorolnak tényleges közhatalmat az al-Hadba büntetés-végrehajtási intézet felett a határozatban ennek ellenkezőjéről olvashatunk. ${ }^{405}$

A bizonyítékok - különösen a tanúk - kapcsán a tárgyalás-előkészítő tanácsnak a Líbiában uralkodó közbiztonsági kihívásokat kellett ismételten megvizsgálnia. ${ }^{406}$ Arra jutott, hogy Líbia szükséges mennyiségú bizonyítékot (okiratok, tanúk) szolgáltatott és a helyi büntetőeljárás előrehaladását alátámasztotta. A tanúvédelmi programok hiányára vonatkozó korábbi aggályait a kamara nem tartotta fenn. ${ }^{407}$

E megállapítás helyességét sokan kétségbe vonták. Egyrészt a védelem több NGO és hírügynökség jelentését a kamara figyelmébe ajánlotta, amelyek az üggyel összefüggésben álló bírákkal és ügyészekkel szembeni erőszakos cselekményekről számoltak be (például arról, hogy az ügyben kirendelt ügyészt 2013 májusában egy milícia elrabolta és bántalmazta). ${ }^{408}$ Christine Van den Wyngaert bíró a határozathoz - szokatlan formai módon - nyilatkozatot csatolt, amiben Ali Zeidan líbiai miniszterelnök 2013. október 10-én történt elrablását is biztonsági kockázatként értékelte, melynek kapcsán további információkérést tartott volna szükségszerûnek az ügy elbírálásához. ${ }^{409}$

A tárgyalás-előkészítő tanács a kifogás elbírálása során végezetül a védő kirendelésének elmulasztását értékelte, mely a két ügy megközelítése közötti inkoherencia legszembetûnőbb pontja. Míg a Kadhafi-ügyből azt szû̉rhettük le, hogy a védő kirendelésének elmulasztása olyan súlyos eljárási szabályszegésnek minősül, hogy az ügy elfogadható az ICC előtt, addig al-Senussi ügyében a védő hiányát a kamara nem értékelte ilyen "durva” jogsértésnek, mi több, figyelembe vette, hogy a terhelt fogva tartásának helyszínére tekintettel a védő kirendelése nem annyira kockázatos, mint Kadhafi esetén, amit az is szemléltet, hogy több ügyvéd is jelezte már a képviselet ellátására való hajlandóságát. ${ }^{410}$ A korábbi esetjog fényében - Kenyatta és mások-ügy, Szajf Kadhafi első

403 Al-Senussi ügye elsőfokú határozat 170-171. \$\$.

404 Al-Senussi ügye elsőfokú határozat 294. \$.

405 Al-Senussi ügye elsőfokú határozat 264. \$.

406 Al-Senussi ügye elsófokú határozat 286-288. \$\$.

407 Al-Senussi ügye elsőfokú határozat 298-301. \$\$.

408 Tedeschini, 2015, 86. o.

409 Declaration of Judge Christine Van den Wyngaert, elérhető: https://www.icc-cpi.int/RelatedRecords/ CR2013_07447.PDF [Letöltve: 2020 . 01. 03.].

410 Al-Senussi ügye elsőfokú határozat 308. \$. 
ügye $e^{411}$ - a tárgyalás-elkészítő tanács e ponton hibát vétett, mivel egy olyan tényt értékelt, ami a kifogás elbírálásának pillanatában nem állt fenn, pusztán a jövőre vonatkozó spekulációnak minősült.

A fentiek alapján a tárgyalás-előkészítő tanács megállapította, hogy al-Senussi ellen „ugyanazon cselekmény” miatt folyik bûnvádi eljárás Líbiában, mint a Nemzetközi Büntetőbíróság előtt, továbbá hogy a helyi hatóságok hajlandóak és képesek az eljárás lefolytatására, ezért az ügy - a Római Statútum 17. cikk (1) bekezdés a) pontja alapján - elfogadhatatlan az ICC előtt. ${ }^{412}$

7.4.1.3. Szajf Kadhafi első ügyének elfogadhatósága és Abdullah al-Senussi ügyének elfogadhatatlansága a fellebbviteli tanács ítéletei tükrében

A fellebbviteli tanács Szajf Kadhafiti3 és al-Senussi ügyében ${ }^{414}$ 2014. májusban, illetve júliusban hozta meg a másodfokú határozatokat. A fellebbezést elbíráló kamara mindkét határozatban foglaltakat - azaz a tárgyalás-előkészítő tanács inkoherens megközelítését - fenntartotta.

A Kadhafi első ügyében hozott elsőfokú határozat ellen Líbia nyújtott be fellebbezést, melyben kérte a fellebbviteli kamarát, hogy a határozatot változtassa meg és elfogadhatósági kifogását hagyja helyben. ${ }^{45}$ Ahogyan az fentebb említésre került, az elsőfokú bírói tanács úgy találta, hogy Líbiának nem sikerült megfelelő bizonyítékok hiányában alátámasztania, hogy a nemzeti büntetőeljárás keretei az ICC előttiével megegyeznek, melyet a fellebbviteli tanács is határozatában rögzített. ${ }^{416}$ Ennek fényében kirajzolódik, hogy az első- és másodfokú kamara megerősítette, hogy a 19. cikk szerinti eljárásokban a bizonyítás terhe a kifogástevőre - így jelen esetben az államra - hárul. ${ }^{177}$ Líbia ugyanakıkor fellebbezésében ez ellen érvelt:

411 A korábbi gyakorlatban kijelölt útra ugyanakkor az ICC tárgyalás-előkészítő kamarája Simone Gbagbo ügyében visszakanyarodott. Lásd az 5.2. pontot.

412 Al-Senussi ügye elsőfokú határozat 311. \$.

413 Judgment on the appeal of Libya against the decision of the Pre-Trial Chamber I of 31 May 2012 entitled "Decision on the admissibility of the case against Saif Al-Islam Gaddafi", The Prosecutor v. Saif Al-Islam Gaddafi, ICC-01/11-01/11-547-Red, ICC Appeals Chamber, 21 May 2014 (a hivatkozásokban a továbbiakban: Szajf Kadhafi elsö ügye másodfokú itélet).

414 Judgment on the appeal of Mr Abdullah Al-Senussi against the decision of the Pre-Trial Chamber I of 11 October 2013 entitled "Decision on the admissibility of the case against Abdullah al-Senussi", The Prosecutor v. Saif Al-Islam Gaddafi, ICC-01/11-01/11-565, ICC Appeals Chamber, 24 July 2014 (a hivatkozásokban a továbbiakban: al-Senussi ügye másodfokú itélet).

415 A fellebbviteli határozathoz Ušacka bíró különvéleményt csatolt, melyben bírálta az elsőfokon eljáró tanácsot a terhelt „ugyanazon cselekményének” minősítése miatt. A különvélemény meglepő érvelése alapján a bíróságnak mindkét ügyet elfogadhatatlannak kellett volna nyilvánítania. Lásd: Dissenting Opinion of Judge Anita Ušacka, elérhető: https://www.icc-cpi.int/RelatedRecords/CR2014_04275.PDF [Letöltve: 2020. 01. 12.]. 416 Szajf Kadhafi elsö ügye másodfokú itélet $45 \$$.

417 Szajf Kadhafi elsö ügye másodfokú itélet 21 \$. 
előadta, hogy a Római Statútum „erốs vélelmet állitfel a nemzeti büntetőeljárások mellett”, és ezért a 17. cikket a bíróságnak eszerint kellene értelmeznie. ${ }^{418}$ Bár utóbbi Líbia kifogásának minden bizonnyal legerősebb argumentuma volt, a fellebbviteli tanács elutasította arra hivatkozva, hogy "a komplementaritás nem jelent egyet azzal, hogy valamennyi ügyet a nemzeti biróságoknak kell elbirálniuk". ${ }^{419}$

Ezzel párhuzamosan megjegyzendő, hogy vélhetően a Biztonsági Tanács által az ICC elé terjesztett helyzetekben a legcsekélyebb a 19. cikk bizonyíthatóságának esélye és a legvalószínúbb a nemzeti eljárások melletti vélelem csorbulása. Mivel a részes államok eljárásindítását a legtöbb esetben saját „tehetetlenségük” katalizálja, olyankor a vélelem is megdőlni látszik eljárási hajlandóságuk és képességük tekintetében. ${ }^{420} \mathrm{Az}$ ICC föügyésze pedig csak részes állammal szemben indíthat proprio motu eljárást, ezáltal a helyi hatóságok eljárása mellett szóló vélelem megdöntése itt sem vet fel szuverenitás-aggályt a Római Statútum önkéntes elfogadása miatt. Azonban amikor az eljárást a Biztonsági Tanács kezdeményezi, „kvázi” előzetes értékelést végez az érintett államról - azaz hogy nem akarja, illetve nem tudja az elkövetőket felelősségre vonni -, s ekkor okozza a nemzeti eljárások melletti vélelem megdöntése a legfeltûnőbb szuverenitástorzulást. ${ }^{421}$

A fellebbviteli tanács felhívta továbbá a figyelmet a Katanga-ügyben meghatározott logikai lépcsőre - és a tárgyalás-előkészítő tanács hibájára - a komplementaritástesztet illetően, melynek értelmében a hajlandóság és a képesség, illetve a „megfelelőség” vizsgálata csak akkor nyer relevanciát, ha ugyanaz az ügy van az ICC előtt, mint a nemzeti rendes bíróság előtt. Ezzel szemben, ha az ügyek azonossága nem bizonyosodik be, akkor nincs értelme a „megfelelőséget” vizsgálni. ${ }^{422}$ A fellebbviteli kamara utóbbiakat alátámasztva a fellebbezés negyedik pontjában foglaltakra nem tért ki, és az eljárási hajlandóság és képesség vizsgálatától eltekintett, egyes álláspontok ${ }^{423}$ szerint utat nyitva az al-Senussi ügyben benyújtott fellebbezés elutasításának.

Al-Senussi ügyében a védelem nyújtott be fellebbezést a Nemzetközi Büntetôbírósághoz, melyben - többek között - olyan új bizonyítékokra hivatkoztak, amelyek a másodfokú határozat elején elutasításra kerültek. ${ }^{424} \mathrm{~A}$ fellebbezésben a tettazonosság kritériumának nemteljesülését is felhozták, melyet a fellebbviteli tanács - a Kenyatta és mások-,

418 Szajf Kadhafi elsö ügye másodfokú itélet 77 \$. 419 Szajf Kadhafi elsö ügye másodfokú itélet 78 \$.

420 Gioia, 2006, 1114. o.

421 Holmes, 2002, 668. o.

422 Szajf Kadhafi elsö ügye másodfokú itélet 213. \$.

423 Tedeschini, 2015, 93. o.

424 Al-Senussi ügye másodfokú itélet 213. \$. 
valamint a Ruto és mások-ügyben foglaltakkal összhangban - a történeti tényállásra alapozva elutasított.

Az al-Senussi és a Kadhafi első ügye között húzódó legvitatottabb ellentmondás a jogi képviselő biztosítása elmaradásának különböző értékelése volt, melyet a 17. cikk (3) bekezdés alapján utóbbi esetben az elsőfokon eljáró kamara úgy értékelt, hogy Líbia „egyébként [nem hajlandó] az eljárás lefolytatására”, míg al-Senussi esetében a jövőre vonatkozó „bizonygatás” elegendő volt ahhoz, hogy a védő hiányától a bíróság eltekintsen. A fellebbviteli tanács az elsőfokú határozat erre irányuló tévedését nem javította ki, és továbbra is a két terhelt fogva tartása helyének különbözőségére alapozta a jogi képviselő lehetséges jövőbeni kirendelésének „jóslatát”. Mindazonáltal e ponton is ismételten megjegyzendő, hogy egyes szerzők $\mathrm{k}^{425}$ a jogi képviselet hiányát olyan durva eljárási jogsértésnek tartják, ami önmagában megalapozhatja az ügy elfogadhatóságát.

Összességében elmondható, hogy a két ügy eltérő kimenetelében a döntő szempontot a terheltek fogvatartási helyszínének különbözősége szolgáltatta: al-Senussit a líbiai hatóságok tartották fogva, Szajf Kadhafit pedig egy irreguláris zintani milícia. Ugyanakkor egyéb szempontokat is figyelembe kellett volna vennie a bíróságnak a kifogások elbírálásakor, és nem kellett volna eltérően közelítenie a jogi képviselet hiányának kérdéséhez. A Római Statútumban foglalt rendelkezések helyes értelmezését csak az ICC szolgáltathatja, ugyanakkor ebben a bírói gyakorlat egészen addig nem tud kiteljesedni, amíg hasonló ténybeli alapokon nyugvó ügyekben inkoherens megközelítést alkalmaz, és árgus szemú kritikusai örömére aláássa saját hitelességét.

\subsubsection{Szajf Kadhafi elfogadhatósági kifogása 26}

2018. június 6-án Szajf Kadhafi maga is elfogadhatósági kifogást nyújtott be az ICC tárgyalás-előkészítő tanácsához arra hivatkozva, hogy 2015. július 28-án a tripoli büntetőbíróság elítélte „tartalmilag ugyanazon cselekményért”, mint amit a Nemzetközi Büntetőbíróság előtti vádak takarnak, valamint hogy a 2015-ben elfogadott líbiai amnesztiatörvény ${ }^{427}$ értelmében 2016. április 12-én - vagy ekörül - de iure szabadult a zintani

425 Mégret és Samson, 2015, 585-586. o.; Tedeschini, 2015, 80. o.

426 Decision on the "Admissibility Challenge by Dr. Saif Al-Islam Gaddafi pursuant to Articles 17(1)(c), 19 and 20 (3) of the Rome Statute", The Prosecutor v. Saif Al-Islam Gaddafi, ICC-01/11-01/11, ICC Pre-Trial Chamber I, 5 April 2019 (a hivatkozásokban a továbbiakban: Szajf Kadhafi második ügye elsőfokú határozat).

427 Kadhafi beadványa szerint a 2005. évi VI. törvény amnesztiában részesített minden olyan líbiai állampolgárt, akit 2011. február 15-től kezdődően a törvény hatálybalépéséig (2015. szeptember 6.) elítéltek, beleértve a büntetett elóélet miatti hátrányoktól való mentesítést is. Lásd: Admissibility Challenge by Dr. Saif Al-Islam Gaddafi pursuant to Articles 17(1)(c), 19 and 20(3) of the Rome Statute, The Prosecutor v. Saif Al-Islam Gaddafi, 
büntetés-végrehajtási intézetből. ${ }^{428}$ A tárgyalás-előkészítő tanács a terhelt kifogását a Római Statútum - a már fentebb ismertetett - 17. cikk (1) bekezdés c) pontja és 19. cikk (2) bekezdés a) pontja, valamint a 20. cikk (3) bekezdése, ${ }^{429}$ a 21. cikk (1) bekezdés a) pontja, illetve (2)-(3) bekezdései, ${ }^{430}$ valamint az ICC Eljárási és Bizonyítási Szabályzatának 58. szabálya ${ }^{431}$ alapján bírálta el. ${ }^{432} \mathrm{~A}$ határozat tartalmilag négy érdemi kérdést vizsgál az elfogadhatósági kifogás vonatkozásában: (i) a szabadlábon lévő terhelt (relatív) perbeli jogképességét; (ii) az anyagi jogeró és a ne bis in idem elv kapcsolatát; (iii) az in absentia itélethozatalt a res iudicata követelményének fényében; valamint (iv) az amnesztia alkalmazhatóságát a nemzetközi bưncselekmények (jelen esetben emberiesség elleni bủncselekmények) esetén. ${ }^{433}$

(i) A Kadhafi beadványára adott válaszában ${ }^{434}$ a Föügyészi Hivatal azzal érvelt, hogy a szabadlábon lévő terhelt nem rendelkezik perbeli jogképességgel az elfogadhatósági kifogás benyújtása tekintetében, ${ }^{435}$ mivel ellene 2011 óta nemzetközi elfogatóparancs van érvényben, azóta pedig sem a líbiai kormány, sem az ICC előtt nem adta fel magát büntetőeljárás le-

ICC-01/11-01/11, ICC Pre-Trial Chamber I, 5 June 2018, \$25 (a hivatkozásokban a továbbiakban: Szajf Kadhafi második ügye védói beadvány).

428 Szajf Kadhafi második ügye elsőfokú határozat 5.\$.

429 Római Statútum 20. cikk (3) bekezdés: „3) Akit másik biróság a 6., 7. és 8. cikk értelmében tiltott cselekmény miatt már elitélt, a Bíróság ugyanazon cselekményért csak akkor itélheti el, ha a másik bíróság eljárása:

a) Azt a célt szolgálta, hogy megvédjék az érintett személyt a Bíróság joghatósága alá tartozó bunncselekmény miatti büntetójogi felelösségre vonás alól; vagy

b) Egyébként nem volt a nemzetközijogáltal elismert tisztességes eljárás szabályainak megfelelö, független vagy pártatlan eljárás, és úgy folyt le, hogy az adott körülmények között nem felelt meg az érintett személy biróság elé állítása szándékának."

430 Római Statútum 21. cikk: „(1) A Bíróság a következőket alkalmazza:

a) Elsősorban a jelen Statútumot, a Büncselekmények Tényállási Elemeit, továbbá az Eljárási és Bizonyitási Szabályokat; $[\ldots]$

(2) A jogi alapelveket és más szabályokat a Bíróság úgy alkalmazhatja, ahogyan azokat korábbi döntéseiben értelmezte.

(3) A jog jelen cikknek megfelelő alkalmazásának és értelmezésének összhangban kell állnia a nemzetközileg elismert emberi jogokkal, és nem lehet hátrányosan megkülönböztető a nemek 7. cikk 3. bekezdésében meghatározott szempontja, életkor, faj, börszín, nyelv, vallás vagy vallásos meggyőződés, politikai vagy egyéb vélemény, nemzeti, etnikai vagy társadalmi származás, vagyon, születés vagy egyéb helyzet szerint."

431 Az ICC Eljárási és Bizonyítási Szabályzatának e pontja a Római Statútum 19. cikke szerinti eljárásokkal kapcsolatban állapít meg részletszabályokat, így például rendelkezik a beadványok írásbeliségének követelményéről, a meghallgatás lehetőségéről, az észrevételek megtételéről, illetve a joghatóság és elfogadhatóság elbírálásának kötött sorrendjéről.

432 Szajf Kadhafi második ügye elsôfokú határozat 18. \$.

433 Megjegyzendő, hogy a bíróság e kérdéseket nem önmagukban, hanem a belső jog - jelen esetben a líbiai büntető anyagi és eljárási jog - tükrében elemzi.

434 Public redacted version of "Prosecution response to 'Admissibility Challenge by Dr. Saif Al-Islam Gaddafi pursuant to Articles 17(1)(c), 19 and 20(3) of the Rome Statute" filed on 28 September 2018 (ICC-01/11-01/11653-Conf), Prosecutor v. Saif Al-Islam Gaddafi, ICC-01/11-01/11, ICC Pre-Trial Chamber I, 11 October 2018 (a hivatkozásokban a továbbiakban: Szajf Kadhafi második ügye föügyészi beadvány).

435 Szajf Kadhafi második ügye fö̈̈̈yészi beadvány 2-3., 83-96. \$\$. 
folytatása céljából („menekül az igazságszolgáltatás elől”).436 Ebből a Főügyészi Hivatal azt a következtetést vonta le, hogy az elfogadhatósági kifogás elutasítása esetén nem lenne valószínúsíthetô, hogy Kadhafi „feladná magát” a líbiai kormánynak a büntető igazságszolgáltatás foganatosítása végett. ${ }^{437}$

Az eljáró kamara az ügyészi érveléssel nem értett egyet, mivel a Római Statútum 19. cikk (2) bekezdése egyértelmúen kimondja, hogy az a személy, akivel szemben letartóztatási parancsot bocsátottak ki, az ügy elfogadhatóságát megtámadhatja, ellenben ezzel párhuzamosan nem szükségszerú a vádlott megjelenése az ICC előtt. ${ }^{438}$ Továbbá jelen esetben a 19. cikk (4) bekezdése ${ }^{439}$ sem jelentett eljárási akadályt, mert az első elfogadhatósági kifogást a Kadhafi-ügyben nem a terhelt, hanem Líbia nyújtotta be. A tárgyalás-előkészítő tanács a Szajf Kadhafi első ügyében hozott elsőfokú határozatban foglaltakra is felhívta a figyelmet, azaz hogy az 1970. (2011) BT-határozat csupán Líbiára - a contrario a terheltre nem - ró együttmúködési kötelezettséget, ami teljesen független az elfogadhatósági kifogás benyújtására való jogosultságtól. Utóbbi az állami együttmúködési kötelezettség elmulasztásának dacára megilleti a terheltet, mi több, még az együttmúködésre kötelezett - ám arra nem hajlandó államot is. ${ }^{440}$

(ii) Az elfogadhatósági kifogásról szóló beadványban Kadhafi védői további érvként hozták fel, hogy a tripoli büntetőbíróság 2015. július 28-án az egykori de facto miniszterelnökre halálbüntetést szabott ki, ez pedig megfelel azon elfogadhatatlansági kritériumoknak, hogy a terhelttel szemben a helyi bíróság ugyanazon búncselekmény vádjában járt el, továbbá kimeríti a Római Statútum 20. cikk (3) bekezdés a)-b) pontjában szereplő, a vádlott megóvását szolgáló, illetve az eljárás megfelelőségére (tisztességes eljáráshoz való jog, függetlenség és pártatlanság) vonatkozó egyéb negatív feltételeket. ${ }^{441}$

Azonban a tárgyalás-előkészítő tanács egyrészt hangsúlyozta, hogy a bizonyítási teher mindig a kifogást tevőre - jelen esetben a védelemre - hárul, másrészt, hogy a ne bis in idem elvet és annak felsorolt részelemeit a statútum 21. cikk (3) bekezdése szerint a nemzetközi emberi jogi sztenderdekkel összhangban kell értelmezni és bizonyítani, ${ }^{442}$ azaz a helyi bírósági eljárásnak olyan „végleges” ítélettel kell zárulnia, amely anyagi jogerővel

436 Szajf Kadhafi második ügye fö̈ügyészi beadvány 2-3., 85. \$\$.

437 Szajf Kadhafi második ügye fö́ugyészi beadvány 3. \$.

438 Szajf Kadhafi második ügye elsőfokú határozat 22. \$.

439 Római Statútum 19. cikk (4) bekezdés: „Az ügy elfogadhatóságáról vagy a Biróság joghatóságáról szóló döntést a 2. bekezdésben írt bármely személy vagy Állam csak egy ízben támadhatja meg. A kifogást a tárgyalás elótt vagy annak megkezdésekor jelentik be. Kivételes esetekben a Bíróság engedélyezheti annak egynél több alkalommal, vagy a tárgyalás megkezdése után történő benyújtását. Az ügy elfogadhatóságának kifogásolása a tárgyalás megkezdésekor, vagy a Bíróság engedélyével késöbb, csak a 17. cikk 1. bekezdésének (c) pontja alapján nyújtható be."

440 Szajf Kadhafi második ügye elsőfokú határozat 24. \$.

441 Szajf Kadhafi második ügye védôi beadvány 2., 24., 34. \$\$.

442 Szajf Kadhafi második ügye elsőfokú határozat 31-32. \$\$. 
(res iudicata) ${ }^{433}$ rendelkezik. ${ }^{444}$ Utóbbit a kamara részint a Bemba-ügy, részint az ad hoc törvényszékek joggyakorlatának részletgazdag felidézésével támasztotta alá. A Bemba-ügyben egy másik tárgyalás-előkészítő tanács elutasította a védelem arra vonatkozó érveit, hogy a nyomozási bíró eljárást megszüntetô végzése érdemi ${ }^{445}$ és végleges, azaz res iudicata természetú. ${ }^{446} \mathrm{Az}$ ICTY, az ICTR és az IRMCT kapcsán a határozat kiemeli, hogy bár a Római Statútum 20. cikk (3) bekezdésében nem szerepel expressis verbis az anyagi jogerő követelménye, a fenti nemzetközi büntető törvényszékek joggyakorlata egyértelmú ebben a kérdésben. ${ }^{477}$ Továbbá a határozat többször is említi, hogy a Római Statútum 20. cikk (3) bekezdését a Polgári és Politikai Jogok Nemzetközi Egyezségokmánya ${ }^{448} 14$. cikk (7) bekezdésével ${ }^{449}$ összhangban (is) kell értelmezni, amelyből egyértelmúen kirajzolódik a res iudicata elv követelménye.

E helyütt a tanács az in absentia ítélethozatalt vette még górcső alá, melyről a líbiai büntető eljárásjog úgy rendelkezik, hogy ha a távollévő terheltet egyszer sikerül őrizetbe venni, az eljárást újból kell kezdeni. ${ }^{450} \mathrm{~A}$ védelem azon érvét, hogy a vádlott videokapcsolattal való jelenlétét úgy kell tekinteni, mintha az ítélethozatal in presentia történt volna, a tárgyalás-elökészítő tanács elutasította. ${ }^{451}$ Ismét a Bemba-ügyre hivatkozva a bírák nem vizsgálták felül a belső jog nemzeti bíróság általi alkalmazásának megfelelőségét, tekintve, hogy az ICC-nek prima facie el kell fogadnia a helyi igazságszolgáltatási szervek határozatainak érvényét és hatályát, hacsak a nemzetközi eljárás során kényszerítő erejú bizonyíték nem merül fel ennek

443 A tárgyalás-előkészítő tanács az anyagi jogerő értelmezése kapcsán az Emberi Jogok Európai Bíróságának és a Nemzetközi Bíróságnak a joggyakorlatát hívta segítségül, melyek szerint az ítélet res iudicata természete azt jelenti, hogy az ellen rendes jogorvoslattal nem lehet élni, vagy a felek a rendes jogorvoslat lehetőségét kimerítették, vagy a benyújtásra nyitva álló határidőt elmulasztották; továbbá a res iudicata elv jogbiztonsági követelményeket is szolgál, mind a perbeli felek, mind az eljáró bíróság szempontjából. Lásd: Szajf Kadhafi második ügye elsőfokú határozat 49. \$.

444 Szajf Kadhafi második ügye elsőfokú határozat 36. \$.

445 „Érdemi elbírálás” alatt az ICC joggyakorlata a felmentést vagy elítélést érti, az eljárás pro forma megszüntetését nem sorolja ide.

446 Bemba-ügy 248. \$.

447 A kamara az ICTR gyakorlatából a Semanza-és a Nzabirinda-ügyeket, az IRMCT gyakorlatából az Orić-ügyet, továbbá a Polgári és Politikai Jogok Nemzetközi Egyezségokmányának 14. cikk (7) bekezdését, az Emberi Jogok Európai Egyezménye Hetedik Kiegészítő Jegyzőkönyvének 4. cikk (1) bekezdését, valamint az Emberi Jogok Amerikai Egyezményének 8. cikk (4) bekezdését hozta fel példának. Lásd: Szajf Kadhafi második ügye elsôfokú határozat 37-46. \$\$. Utóbbit lásd még: Raisz, 2010, 281-295. o.

448 1976. évi 8. törvényerejû́ rendelet az Egyesült Nemzetek Közgyưlése XXI. ülésszakán, 1966. december 16-án elfogadott Polgári és Politikai Jogok Nemzetközi Egyezségokmánya kihirdetéséről.

449 PPJNE 14. cikk (7) bekezdés: „Senkivel szemben sem lehet büntetőeljárást indítani vagy büntetést kiszabni olyan büncselekmény miatt, amely miatt az adott ország törvényének és büntetőeljárásának megfelelően jogerôs itélettel már elitélték vagy felmentették."

450 Szajf Kadhafi második ügye elsőfokú határozat 48. \$.

451 Szajf Kadhafi második ügye elsőfokú határozat 48-51. \$\$. 
ellenkezőjét indikálva. ${ }^{452}$ Jelen ügyben azonban a kamara szükségtelen beavatkozásként értékelte a líbiai eljárásba történő efféle beavatkozást, az állami jogalkalmazás helyességének felülvizsgálatát. ${ }^{453}$

(iv) A védelem beadványára reflektálva az elsőfokú határozat a közkegyelem kérdésével is foglalkozott, és arra jutott, hogy a 2015-ben elfogadott líbiai amnesztiatörvény tárgyi hatálya ${ }^{454}$ a Kadhafi ellen felhozott vádpontokban szereplő büncselekményekre (emberölés, emberrablás, erőszakos eltúnés és kínzás) nem terjed ki. A kamara kitért arra, hogy a terhelt ellen 2011. június 26-án kibocsátott letartóztatási parancs szerint alapos gyanú áll fenn arra nézve, hogy a vádlott emberiesség elleni bûncselekményeket (emberölést és üldözést) követett el, ehhez párhuzamosan pedig egyértelmúen társul az az „eróteljesen növekedö tendencia a nemzetközi jogban", ${ }^{455}$ hogy súlyos és szisztematikus emberi jogi jogsértések esetén közkegyelmet és egyéni kegyelmet nem lehet adni. .56

A fentiekre tekintettel tehát a tárgyalás-előkészítő tanács úgy találta, hogy a helyi bíróságok Szajf Kadhafi ügyében érdemi és végleges ítéletet nem hoztak, a védelemnek pedig nem sikerült a Római Statútum 17. cikk (3) bekezdésében és a 20. cikk (3) bekezdés a) pontjában foglaltakat ${ }^{457}$ bizonyítania, így a tanács a vádlott elfogadhatósági kifogását elutasította.

A tárgyalás-előkészítő tanács határozata ellen Szajf Kadhafi fellebbezett, ${ }^{458}$ amelyet az ICC fellebbviteli tanácsa 2020. március 9-én hozott egyhangú ítéletével ${ }^{459}$ elutasított. A védelem

452 Bemba-ügy 66. \$ és Szajf Kadhafi második ügye elsőfokú határozat 52. \$.

453 Szajf Kadhafi második ügye elsőfokú határozat 53. \$.

454 State of Libya Libyan House of Representatives, Law 6/2015 on General Amnesty, elérhető: https://www. legal-tools.org/doc/2c966c/pdf/ [Letöltve: 2020.05.17.]. Az amnesztiatörvény 3. cikke felsorolja azokat a búncselekményeket, melyek elkövetése esetén közkegyelem nem adható. Ezek: terrorcselekmény, kábítószer-csempészet, kábítószer-kereskedelem, szexuális bántalmazás, „személyazonosság-alapú emberölés” (kvázi a gyưlölet-bûncselekmény egyik formája), emberrablás, erőszakos eltűnés, kínzás, egyes (iszlám) saría büncselekmények és a korrupció valamennyi alakzata.

455 Ezzel kapcsolatban a tárgyalás-előkészítő tanács elsősorban az Emberi Jogok Amerika-közi Bíróságának, illetve az Emberi Jogok Európai Bíróságának, az Ember és Népek Jogainak Afrikai Bizottságának, az ENSZ Emberi Jogi Bizottságának, az ICTY-nak, az SCSL-nek és az ECCC-nek joggyakorlatára tért ki. Lásd: Szajf Kadhafi második ügye elsófokú határozat 62-76. \$\$.

456 Szajf Kadhafi második ügye elsőfokú határozat 60-61. \$\$.

457 Mivel a Római Statútum 20. cikk (3) bekezdésében foglalt feltételek kumulatívak, így annak a) pontjában szereplő feltétel bizonyításának sikertelensége miatt a tárgyalás-előkészítő tanács szükségtelennek tartotta, hogy a b) pontban szereplő feltételeket részletesen megvizsgálja. Lásd: Szajf Kadhafi második ügye elsőfokú határozat $79 . \$$.

458 Defence Appeal Brief in support of its appeal against Pre-Trial Chamber I's "Decision on the 'Admissibility Challenge by Dr. Saif Al-Islam Gadafi pursuant to Articles 17(1)(c), 19 and 20(3) of the Rome Statute", The Prosecutor v. Saif Al-Islam Gaddafi, ICC-01/11-01/11, Appeals Chamber, 20 May 2019.

459 Judgment on the appeal of Mr Saif Al-Islam Gaddafi against the decision of Pre-Trial Chamber I entitled 'Decision on the "Admissibility Challenge by Dr. Saif Al-Islam Gadafi pursuant to Articles 17(1)(c), 19 and 20(3) of the Rome Statute"' of 5 April 2019, The Prosecutor v. SaifAl-Islam Gaddafi, ICC-01/11-01/11, Appeals Chamber, 9 March 2020 (a hivatkozásokban a továbbiakban: Szajf Kadhafi második ügye másodfokú itélet). 
a fellebbezésben azzal érvelt, hogy az elsőfokon eljáró tanács jogi tévedésbe esett (i) egyrészt akkor, amikor a Római Statútum 17. cikk (1) bekezdés c) pontját és a 20. cikk (3) bekezdését úgy értelmezte, hogy egy ICC előtti ügy elfogadhatatlanságához res iudicata „természetư" ítéletre van szükség; (ii) másrészt akkor, amikor a líbiai amnesztiatörvény terheltre vonatkoztatását nem minősítette az ügy végleges lezárásának. ${ }^{460}$

(i) A fellebbviteli tanács megerősítette, hogy a helyi büntetőeljárás lefolytatására a terhelt távollétében került sor, melyet mind a tripoli bíróság, mind a líbiai kormány, mind a tárgyalás-előkészítő tanács álláspontja alátámasztott, ám ennek ellenkezőjét - tudniillik hogy a vádlott „biztonsági okokból” videokapcsolaton keresztül megvalósított alkalmi bekapcsolódása a tárgyalásokba személyes jelenlétnek minősül - a védelemnek nem sikerült bizonyítania, Líbia büntetô eljárásjoga alapján pedig az in absentia ítélet a res iudicata követelményével nem egyeztethető össze. ${ }^{461} \mathrm{~A}$ másodfokon eljáró kamara az elsőfokú tanáccsal ellentétben a res iudicata terminológiát szándékosan nem használta, helyette a Római Statútumban szereplő fordulatot [„az érintett személyt (...) már felelősségre vonták”] alkalmazta, és az ítélet véglegességét hangsúlyozta azzal, hogy utóbbi követelménye teljes mértékben összhangban áll a komplementaritás keretrendszerével, valamint az államok joghatóságának elsőbbségével. ${ }^{462}$ A fellebbviteli bírák szerint a tárgyalás-elôkészítő tanács az ad hoc törvényszékek és a különböző emberi jogi fórumok gyakorlatát a ne bis in idem elv és az emberi jogi sztenderdek kapcsán hiba nélkül azonosította be és értelmezte, így a terhelt fellebbezését a fentiek tekintetében elutasította. ${ }^{463}$

(ii) A fellebbezés második pillérét a védelem arra alapozta, hogy még ha a Római Statútum 17. cikk (1) bekezdés c) pontja és 20 . cikk (3) bekezdése meg is követelik az állami büntetőeljárás véglegességét, az ügy továbbra is elfogadhatatlan az ICC előtt, mert a 2015-ben elfogadott líbiai amnesztiatörvény értelmében a terhelt kegyelemben részesült. ${ }^{464} \mathrm{~A}$ fellebbviteli tanács az elsőfokú határozatot ezen érv tekintetében szintén helyben hagyta - irrelevánsnak tekintve a védelem „személyazonosság-alapú emberölés” és emberölés megkülönböztetésére vonatkozó érveit -, megerősítve, hogy a líbiai amnesztiatörvényt a Kadhafi által elkövetett deliktumokra nem lehet alkalmazni. ${ }^{465} \mathrm{~A}$ másodfokú ítélet a tárgyalás-elókészítő tanács által az amnesztia és a nemzetközi bưncselekmények kapcsolatáról írtakat obiter dictumnak minősítette arra hivatkozva, hogy az ügy érdemben eldönthető pusztán Líbia belső joga alapján, mert az amnesztiatörvény

460 Szajf Kadhafi második ügye másodfokú itélet 5 . \$. 461 Szajf Kadhafi második ügye másodfokú itélet 49-53. \$\$. 462 Szaif Kadhafi második ügye másodfokú itélet 61. \$. 463 Szajf Kadhafi második ügye másodfokú itélet 62-63. \$\$. 464 Szajf Kadhafi második ügye másodfokú itélet 85 . \$. 465 Szajf Kadhafi második ügye másodfokú itélet 87. \$. 
tárgyi hatálya egyértelmúen nem alkalmazható a Kadhafi elleni vádakban szereplő bưncselekményekre. ${ }^{466}$

A másodfokú ítélethez csatolt rövid párhuzamos indokolásukban ${ }^{467}$ Chile Eboe-Osuji tanácselnök és Solomy Balungi Bossa bíró a komplementaritás elemi lényegéhez kapcsolódóan fejtettek ki néhány absztrakt gondolatot, kiragadva a védelem azon érvét, hogy a Nemzetközi Büntetőbíróságnak nem feladata az állami bíróság ítéletének felülvizsgálata, mert az ICC „nem Líbia Legfelsóbb Bírósága”, az olyan döntés pedig, amelyik túlságosan beleássa magát a belső jog értelmezésébe, szem elől téveszti a komplementaritás valódi célját. ${ }^{468}$ Eboe-Osuji és Bossa bírák - egyetértve az amicus curie álláspontjával - hangsúlyozták: „az, hogy a komplementaritás rendszere ténylegesen mennyire járul hozzá a büntetlenség felszámolásához, teljes mértékben attól függ, hogy a gyakorlatban hogyan alkalmazzák". (Tudniillik ha az ICC indokolatlanul beleavatkozik a nemzeti szintű büntetőeljárásba, azzal pont a Római Statútum és a komplementaritás érvényre juttatása ellen hat). Rávilágítottak továbbá a komplementaritás elméleti „vonzereje” és gyakorlati elfogadottsága közötti éles kontrasztra - azaz amint felmerül az alkalmazása egy konkrét ügyben, rögtön megjelenik az állami „szuverenitást” védelmező tiltakozás ${ }^{469}$-, és felvetették azt a dilemmát, hogy vajon valóban lehet-e büntetlenségről beszélni akkor, ha a terhelt a helyi büntetőeljárás és elítélés után részesült kegyelemben, valamint hogy ilyen esetben mennyiben ütközik az ügy elfogadhatóvá nyilvánítása a kétszeres értékelés tilalmával? ${ }^{470} \mathrm{~A}$ bírák e „filozofikus" kérdéseket maguk is nyitva hagyták.

Az aktuális joggyakorlat tükrében a Biztonsági Tanács által a Nemzetközi Büntetőbíróság elé vitt helyzetek legfontosabb jogi problémáinak elemzése során a komplementaritás részletes vizsgálata elengedhetetlennek bizonyul, az eddig az ICC által tárgyalt líbiai ügyek tengelye ugyanis vitathatatlanul az elfogadhatóság körül forgott, s mint a részes államok és föügyész által kezdeményezett büntetőeljárások esetén, a bíróság kéktaláros testülete újabb értelmező adalékokkal gazdagította a nemzetközi büntetőjogi juriszdikciót ezen egyedülálló joghatóság-koncepció tekintetében.

466 Szajf Kadhafi második ügye másodfokú itélet 96 . \$.

467 Concurring Separate Opinion of Judge Eboe-Osuji and Judge Bossa, elérhető: https://www.icc-cpi.int/RelatedRecords/CR2020_00905.PDF [Letöltve: 2020. 05. 17.] (a hivatkozásokban a továbbiakban: Eboe-Osuji és Bossa birák párhuzamos indokolása).

468 Eboe-Osuji és Bossa birák párhuzamos indokolása 2. \$.

469 Eboe-Osuji és Bossa bírák párhuzamos indokolása 5-6. \$\$.

470 Eboe-Osuji és Bossa bírák párhuzamos indokolása 7-8. \$\$. 
A vizsgált ügyek közül a Szajf Kadhafi második ügyében tett bírói megállapítások tesznek hozzá értékesebb hozadékot a jogtudomány fejlődéséhez, mivel a Kadhafi első ügyében, illetve az al-Senussi ügyében hozott döntések inkoherenciája a védő kirendelése elmulasztásának értékelésében utóbbiakat egyértelmúen az ICC kevésbé „jól sikerült” határozatai és ítéletei közé számúzte, mely következetlenség könnyen elhintette a politikai alapú elfogultság és a pártatlanság hiányát felhozó bírálatok magjait. Szajf Kadhafi két ügye nyilvánvalóan de iure kevésbé összehasonlítható az eltérő történeti tényállások és ebből adódóan a kifogást benyújtók (először Líbia, aztán maga a vádlott) eltéró érvei, továbbá a bíróság által értékelt eltérő szempontok miatt, így erre jelen kötet sem vállalkozik, ugyanakkor a Kadhafi második ügyében hozott döntések értékelésére ${ }^{471}$ per se érdemes néhány gondolatot szentelni még e fejezet lezárása előtt.

A tárgyalás-előkészítő tanács határozata elsőként az elfogadhatósági kifogás benyújtására való jogosultság - vagy általánosabban a terhelt relatív perbeli jogképességének - kérdésével foglalkozott, melyet egyrészt a Római Statútum 19. cikk (4) bekezdésének első fordulatának („Az ügy elfogadhatóságáról vagy a Bíróság joghatóságáról szóló döntést a 2. bekezdésben írt bármely személy vagy Állam csak egy ízben támadhatja meg") értelmezésével tisztázott. Ez alapján nyilvánvalóvá vált, hogy az egyszeri megtámadás lehetőségét a kifogástételre jogosultak vonatkozásában egyenként, és nem az összes kifogástevőre egyetemlegesen kell értelmezni. Az, hogy a joghatósággal rendelkező állam korábban kifogást nyújtott be, és azt a bíróság elutasította, nem zárja ki, hogy a terhelt később ugyanezen jogával éljen. Másrészt az elsőfokon eljáró kamara kategorikusan tisztázta, hogy a 19. cikk (2) bekezdés a) pontja alapján a terhelt elfogadhatósági kifogástételére való jogosultságának nem előzetes feltétele, hogy feladja magát az ICC előtt, ami részben a fenti szakasz nyelvtani értelmezéséből - és bár a tanács nem hivatkozott rá, vélhetően az in dubio pro reo elvből is -, részben az 1970. (2011) BT-határozat személyi hatályából adódik (tudniillik a Biztonsági Tanács a jövőbeli terhelteket nem, csak Líbiát kötelezte az ICC-vel való együttmüködésre).

Mind az elsőfokú határozat, mind a fellebbviteli tanács ítélete tekintélyes terjedelemben foglalkozott az elfogadhatósági kifogásban hivatkozott állami bíróság ítéletének véglegességével. Jóllehet a tárgyalás-előkészítő tanács a Bemba-ügy, valamint az ICTY, az ICTR és az IRMCT joggyakorlatának és a PPJNE 14. cikk (7) bekezdésének felidézésével meggyőzően érvelt amellett, hogy a nemzeti bíróságok ítéletének véglegességén az anyagi jogerőt kell érteni, a másodfokú ítélet az elsőfokon eljáró tanács érvelésének

471 E helyütt csak azokat a megállapításokat villantom fel, amelyek a nemzetközi jog szempontjából relevánsak, és mellőzöm azokat a következtetéseket (in absentia elítélés, líbiai amnesztiatörvény tárgyi hatálya), amelyeket a bíróság a belső jog alapján vont le. 
helyben hagyása mellett a res iudicta terminológiát szándékosan nem alkalmazta, megmaradva a Római Statútum szikár szóhasználata [„,az érintett személyt (...) már felelösségre vonták"] mellett.

Szintén figyelemre méltó a tárgyalás-előkészítő tanács gazdag esetjogi merítése a nemzetközi emberi jogi fórumok előtti ügyekből, mellyel meggyőzően érvelt - az ICC történetében elsőként - az amnesztia nemzetközi büncselekményekre való alkalmazhatósága ellen. Noha a Római Statútum az amnesztia kérdését szándékosan mellőzi, a kamara álláspontjából egyértelmúen kirajzolódik a "no peace without justice” megközelítése. Ezzel szemben a fellebbviteli tanács - feltehetően a kegyelem demokratikus átmenetben és társadalmi megbékélésben játszott kettős („kényszeredett, de szükséges”) hatásai ${ }^{472}$ miatt - az amnesztia és a nemzetközi búncselekmények kapcsolatának elemzésétôl eltekintett, s úgy utasította el a védelem erre irányuló fellebbezését pro forma belső jogi érvekre hivatkozva, hogy az elsőfokú tanács erre vonatkozó érvelését obiter dictumnak minősítette.

A Szajf Kadhafi második ügyében hozott döntésekkel kapcsolatban megállapítható, hogy a tárgyalás-előkészítő tanács sokkal bátrabban közelített az esetben felmerülő, „széles spektrumú" nemzetközi büntetőjogi kérdések vizsgálatához, mint a fellebbviteli szak, és utóbbi az elsőfok megállapításait ugyan helyben hagyta, azt „biztonsági játékot úzve" tette, azaz csupán a Római Statútum értelmezésére és Líbia belső jogára alapozva ítélkezett.

472 Cryer et al., 2016, 569-573. o. 


\section{Az együttmülködés, a nemzetközi elfogatóparancsok végrehajtása és a Biztonsági Tanács által kezdeményezett eljárások}

\subsection{Problémafelvetés: az államföi immunitás és a büntetlenség elleni harc}

Az immunitás jogintézménye a kortárs nemzetközi jog egyik „divatos” területe, elég csak visszatekinteni a Nemzetközi Bíróság esetjogának elmúlt 20 évére, ${ }^{473}$ vagy rápillantani a Nemzetközi Jogi Bizottság ágendájára, ${ }^{474}$ melyen az állami tisztviselók külföldi büntető joghatóság alóli immunitása aktuális témaként ${ }^{475}$ szerepel.

Az (államfôi) immunitás a Nemzetközi Büntetőbíróságot is komoly kihívások elé állítja, hiszen a bíróság múködési hatékonyságát érő legsúlyosabb kritikák egyike, hogy az ICC nem képes az általa kiadott letartóztatási parancsoknak érvényt szerezni, nem képes a terhelteket elóállítani és a büntetőeljárást lefolytatni, végső soron pedig nem képes a nemzetközi büntető igazságszolgáltatásban ráosztott szerepet betölteni. Utóbbi állítás különösen igaz akkor, amikor a Biztonsági Tanács által kezdeményezett eljárásokról és harmadik államok állampolgárságát viselő vádlottakról van szó.

A fenti probléma Dov Jacobs szerint teoretikusan leegyszerúsítve két, a nemzetközi jog által egyaránt védendő jogterület logikai perspektívából közelíthető meg: az állami szuverenitás és az emberi jogok, konkrétabban az államfói immunitás és a nemzetközi büncselekmények áldozatainak szemszögéből. ${ }^{476}$ Megállapításával egyetértve, a jogi probléma átláthatóságát elősegítendő egy metodológiai térkép felvázolása tűnik célszerűnek, melyet - az ICC és a Római Statútumban nem részes államok együttmúködését, valamint az államfői immunitás kérdését is figyelembe véve - három befolyásoló tényező szerint lehet megrajzolni.

Az osztályozás az eljárást indító mechanizmusokból indul ki, mely alapján három olyan elméleti eset létezik, amikor egy Római Statútumban nem részes állam állampolgára

473 Jurisdictional Immunities of the State (Germany v. Italy: Greece Intervening), Judgment of 3 February 2012, I.C.J. Reports 2012, 99; Case Concerning Certain Questions of Mutual Assistance in Criminal Matters (Djibouti v. France), Judgment of 4 June 2008, I.C.J. Reports 2008, 177; Case Concerning the Arrest Warrant of 11 April 2000 (Democratic Republic of the Congo v. Belgium), Judgment of 14 February 2002, I.C.J. Reports 2002, 3 (a hivatkozásokban a továbbiakban: Yérodia-ügy).

474 A Nemzetközi Jogi Bizottság aktuális tevékenységéról és a munka állásáról lásd: https:/legal.un.org/ilc/status.shtml [Letöltve: 2020. 01. 27.].

$475 \mathrm{Az}$ állami tisztviselők külföldi büntető joghatóság alóli immunitásának címú jogterület kodifikációját és progresszív továbbfejlesztését a Nemzetközi Jogi Bizottság 2006-ban túzte programjára. A munka jelen állása szerint az ILC 2019. évi 71. ülésszakján Concepción Escobar Hernández rapporteur hatodik jelentését tárgyalta, mely javarészt eljárásjogi kérdésekre helyezte a hangsúlyt. Lásd: https://legal.un.org/ilc/summaries/4_2.sht$\mathrm{ml}$ [Letöltve: 2020. 01. 20.].

476 Jacobs, 2015, 281. o. 
a bíróság elé kerülhet vádlottként. Az első az, (i) amikor egy részes állam területén egy nem részes állam állampolgára követ el nemzetközi bủncselekményt [Római Statútum 12. cikk (2) bekezdés ${ }^{477}$, és a részes állam az ICC elé utalja a konfliktusos helyzetet. Ennek analóg alkategóriája, ha egy nem részes állam a Római Statútum 12. cikk (3) bekezdésében ${ }^{478}$ biztosított lehetőséggel élve, ad hoc jelleggel az ICC elé utalja a konfliktusos helyzetet, és szintén nem részes állam állampolgárával szemben merül fel büncselekmény elkövetésének alapos gyanúja. Az önkéntes alávetés a területileg érintett állam részérôl mindkét esetben fennáll.

A második, (ii) amikor egy részes állam területén egy nem részes állam állampolgára követ el nemzetközi búncselekményt, és a Főügyészi Hivatal az ICC elé utalja az ügyet. Az önkéntes alávetés esete - a szerződés ratifikálása, az ahhoz való önkéntes csatlakozás alapján vélelmezve - szintén fennáll, még ha a területi elven nyugvó joghatóság-gyakorlást egyes harmadik államok - így például az Egyesült Államok - hevesen bírálják is.

A harmadik, (iii) amikor egy nem részes állam területén egy nem részes állam állampolgára követ el nemzetközi bưncselekményt, és a Biztonsági Tanács az ICC elé terjeszti a konfliktusos helyzetet. Ekkor az önkéntes alávetés teljes mértékben hiányzik, így ezen esetkör az első kettőhöz képest jogilag más megítélés alá esik, „érzékenyebb atmoszférát” teremt, és az ebből adódó jogviszonyokban nemcsak a Római Statútumot, hanem az ENSZ Alapokmányát és a Biztonsági Tanács vonatkozó határozatát is irányadó jogforrásként kell alkalmazni. Ellenben az némileg vitatott, hogy ilyenkor mely normák vonatkoznak a harmadik államokra? Csupán az ENSZ Alapokmánya, a Biztonsági Tanács konkrét határozata és - természetesen - a nemzetközi szokásjog, vagy a Római Statútum rendelkezéseit is alkalmazni kell rájuk? (Ez az esetkör - a későbbi vizsgálódás megkönnyítése érdekében a továbbiakban „vertikális hatály” cím alatt kerül említésre, mivel itt az ICC és harmadik államok jogviszonyáról van szó.) Valamint azt is szükséges megvizsgálni, hogy mely normák vonatkoznak ezen harmadik államokra a Római Statútumban részes államokkal való együttmúködés során? Csupán a nemzetközi szokásjog, vagy itt is alkalmazni kell rájuk a Római Statútumot? (Praktikusan: „horizontális hatály”.).79

477 Római Statútum 12. cikk (2) bekezdés b) pont: „A 13. cikk a) vagy c) pontja szerinti esetekben a Bíróság akkor gyakorolhatja joghatóságát, ha a következóÁllamok közül egy vagy több Részese a jelen Statútumnak, vagy elfogadta a Bíróság joghatóságát a 3. bekezdésnek megfelelően: Az az Állam, amelynek a büncselekmény elkövetésével vádolt személy az állampolgára."

478 Római Statútum 12. cikk (3) bekezdés: „Ha Bíróság joghatóságának olyan Állam általi elfogadása szükséges a 2. bekezdés szerinti célból, amely a jelen Statútumban nem Részes Állam, az adott Állam a hivatalvezetőhöz benyújtott nyilatkozattal elfogadhatja az adott büncselekmény tekintetében a Bíróság joghatóságát. Az elfogadó Állam késedelem és kivétel nélkül a IX. Fejezetben meghatározottak szerint együttmüködik a Bírósággal."

479 Jacobs, 2015, 284-286. o. 
A probléma kusza szálai még tovább gabalyodnak, ha az adott helyzet kapcsán az elkövető hivatalos minőségének fennállása is felmerül. Ekkor az alkalmazandó jogforrások meghatározása után azt is meg kell vizsgálni, hogy e jogforrások hogyan rendelkeznek a hivatalos minőség kérdéséról nemzetközi büntetőbírói fórumok eljárása esetén - mind anyagi jogi, mind eljárásjogi értelemben. Tudniillik, hogy a nemzetközi szerződések, a szokásjog és a nemzetközi bíróságok gyakorlata hogyan rendelkeznek az immunitásról és a hivatalos minőség fennállásának (ir)relevanciájáról.

Az ICC gyakorlatában e probléma a következő módon jelentkezik. Amikor a tárgyalás-elókészítő tanács kibocsát egy letartóztatási parancsot, akkor - bizonyos egyéb objektív feltételek fennállása esetén - kötelezi a Római Statútumban részes államokat a letartóztatás foganatosítására és a terhelt átadására. Abban az esetben, ha a megkeresett és a terhelt állampolgársága szerinti állam is részese a statútumnak, akkor az együttmû́ködési hajlandóság szemszögéből aligha beszélhetünk problematikus esetről, mivel a terhelt állampolgársága szerinti állam a szerződés ratifikációjakor vagy az ahhoz való csatlakozáskor önként vállalta a statútumban foglalt jogi kötelezettségek teljesítését, valamint hogy adott esetben állampolgárait a nemzetközi bírói fórum előtti felelősségre vonásnak aláveti. ${ }^{480}$

Jelen fejezet tehát azt a jogilag és politikailag érzékeny kérdést járja körbe, amikor a nemzetközi elfogatóparancsban nevesített személy állampolgárság szerinti állama nem részes fél a Római Statútumban. Utóbbi esetben ugyanis felmerül a kérdés, hogy vajon a letartóztatási parancs végrehajtása nem vezet-e az államok oldaláról egyéb nemzetközi jogi kötelezettségük, nevezetesen az államfőknek, kormányfőknek, külügyminisztereknek és diplomatáknak járó mentességnek a megsértéséhez?

A fenti probléma legmarkánsabb gyakorlati megnyilvánulása - már-már klasszikus, ám tragikus iskolapéldája -, hogy a Nemzetközi Büntetőbíróság 2009 márciusa óta nem képes Omár al-Bashír ${ }^{81}$ - e sorok írásakor immár csak egykori - szudáni államfő letartóztatását foganatosítani annak ellenére, hogy erre számos alkalommal adódott volna lehetősége a Római Statútumban részes államoknak. Ami a volt szudáni elnök megváltozott jogállását illeti, megjegyzendő, hogy al-Bashír 2019 tavaszáig volt az afrikai ország államfője, amikor is katonai erők az egyre fokozódó tiltakozások közepette hivatalából - majdnem 30 év után - elmozdították. Az ügy jelen állása kapcsán Fatou Bensouda a Biztonsági Tanácshoz

480 Gondoljunk például az ICC-hez segítségért forduló „erőtlen” kormányokra és a nem állami szereplőkre, így például Ugandának és az Úr Ellenállási Hadseregének vagy a Kongói Demokratikus Köztársaságnak az eseteire. Lásd: Situation in Uganda, elérhető: https://www.icc-cpi.int/uganda [Letöltve: 2020. 05. 20.]; Situation in the Democratic Republic of the Congo, elérhető: https://www.icc-cpi.int/drc [Letöltve: 2020.05 .20 .].

481 The Prosecutor v. Omar Hassan Ahmad Al-Bashir, ICC-02/05-01/09, Case Information Sheet, elérhető: https://www.icc-cpi.int/CaseInformationSheets/albashirEng.pdf [Letöltve: 2020. 05. 20.]. Lásd erről bővebben: Béres, 2015, 11-26. o. 
intézett 2019. június 19-i jelentésében ${ }^{482}$ hangsúlyozta annak jelentőségét, hogy Szudánban komoly politikai átalakulás zajlik: 2019. február 22-én, több hónapos kormányellenes tüntetéseket követően, al-Bashír elnök különleges jogrendet hirdetett ki, majd 2019. április 11-én az ország védelmi minisztere, Ibn Aufa szúnni nem akaró kormányellenes megmozdulások közepette bejelentette, hogy al-Bashirt letartóztatták, az alkotmányt felfüggesztették, a törvényhozást feloszlatták, ezzel párhuzamosan pedig létrehozták az Átmeneti Katonai Tanácsot (Transitional Military Council). A Fóügyészi Hivatal információi szerint al-Bashírt egy kartúmi büntetés-végrehajtási intézetbe szállították, a helyi média pedig arról számolt be, hogy a szudáni hatóságok pénzmosással, terrorizmusfinanszírozással és kormányellenes tüntetők megölésével vádolják. Bensouda jelentésében ezzel párhuzamosan nyomatékot adott annak, hogy a komplementaritás elvének értelmében al-Bashir felelősségre vonása elsősorban a helyi büntetőbíróságok feladata. 2019 decemberében nagy port kavart a világsajtóban a hír, ${ }^{483}$ hogy al-Bashírt korrupció, megvesztegetés és deviza jogellenes birtoklásának vádja miatt mindössze két év szabadságvesztés-büntetésre ítélték, melyet - tekintettel időskorára - nem börtönben, hanem egy rehabilitációs intézetben kell letöltenie. Az enyhe vádak és kiszabott büntetés ellen újabb tüntetések ütötték fel a fejüket Szudánban, követelve al-Bashír 1989-es államcsínyben való részvételének kivizsgálását, továbbá az ICC Főügyészi Hivatala vádindítványában szereplő búntettekért - többek között népirtásért való felelősségre vonását.

A monográfia a továbbiakban szem elôtt tartja al-Bashír megváltozott nemzetközi jogi státuszát, ugyanakkor a bemutatni szánt probléma ábrázolása céljából továbbra is egykori államfői minőségében hivatkozik rá. Jelen fejezet ezáltal a releváns jogszabályi háttér bemutatása, a konkrét jogi probléma lehatárolása, a lehetséges metodológiai megközelítések megvonása, valamint a probléma gyakorlati nehézségeinek ismertetése után a jogirodalomban és a joggyakorlatban fellelhető esetleges elméleti megoldások feltárását és ütköztetését túzi ki céljául.

482 Twenty-Ninth Report of the Prosecutor of the International Criminal Court to the United Nations Security Council Pursuant to UNSCR 1593 (2005), elérhető: https://www.icc-cpi.int/itemsDocuments/ 190619-rep-otp-UNSC-Darfur-Sudan-ENG.pdf [Letöltve: 2020. 01. 25.].

483 Lásd a világsajtó vezető hírügynökségeinek honlapjait: https://www.theguardian.com/world/2019/dec/14/sudanese-court-sentences-omar-al-bashir-to-2-years-in-prison; https://www.aljazeera.com/news/2019/12/14/ sudans-omar-al-bashir-sentenced-to-two-years-for-corruption; https://www.bbc.com/news/world-africa-50794096; https://www.euronews.com/2019/12/14/ousted-sudan-president-bashir-convicted-for-corruption [Mind letöltve: 2020.01 .25 .]. 


\subsection{A probléma normatív háttere}

\subsubsection{Az együttmüködési kötelezettség a Biztonsági Tanács 1593. (2005) határozatában}

A probléma jogszabályi hátterének feltárásához ismét a Biztonsági Tanács 1593. (2005) határozatát ${ }^{484}$ és a Római Statútum idevonatkozó rendelkezéseit szükséges közelebbről megvizsgálni.

Mint ahogyan arról korábban már szó esett, a dárfúri konfliktust a Biztonsági Tanács 1593. (2005) határozata utalta az ICC elé 2005. március 31-én. Ami a határozat terjedelmét illeti, a normaszöveg rövid és tömör - mindössze két oldal -, valamint - a BT-határozatok viszonylatában teljesen megszokott módon - általánosító, ami nem kevés jogértelmezési kérdésnek biztosít gazdag táptalajt. Mindazonáltal ez az általánosítás a Nemzetközi Büntetőbíróság szempontjából tekintve egyben kívánatosnak is mondható, ha figyelembe vesszük, hogy a Biztonsági Tanács nem igazságszolgáltatási szerv, így nem gyanúsíthat és vádat sem emelhet, mely utóbbira a Római Statútum a Főügyészi Hivatalnak biztosít kizárólagos felhatalmazást.

Az együttmúködés kérdéséről az 1593. (2005) BT-határozat 2. cikke rendelkezik, mely kimondja, hogy „a Biztonsági Tanács úgy határoz, hogy Szudán kormánya és a dárfúri konfliktus többi résztvevője a birósággal és a föügyésszel teljes mértékben köteles együttmüködni, valamint e határozat alapján számukra minden szükséges segítséget biztositani. Továbbá, bár a Biztonsági Tanács elismeri, hogy a Római Statútumban nem részes államokra a Római Statútum semmiféle kötelezettséget nem ró, valamennyi államot, illetve az érintett regionális és nemzetközi szervezeteket arra hivja fel, hogy ők is teljes mértékben müködjenek együtt a Bírósággal."

A norma szövegéből kitűnik: annak ellenére, hogy a Biztonsági Tanács megtehette volna, a határozat a harmadik államokat együttmüködésre nem kötelezi. Úgyszintén a részes államok együttmúködési kötelezettségének megerősítésére sem kerül sor, így ezen államok együttműködési kötelezettsége továbbra is „csupán” közönséges nemzetközi szerződéses normákból fakad. A határozat egyedül Szudánt szólítja fel expressis verbis, hogy múködjön együtt a bírósággal, mely Szudánra nézve az ENSZ Alapokmányának 25. cikke értelmében kötelező erejü.

A határozat szövege Szudán jogállására sem tér ki, azaz érintetlenül hagyja azt a kérdést, hogy a dárfúri helyzet bíróság elé terjesztése után a Római Statútum normái ugyanúgy vonatkoznak-e rá, mint a statútumban részes államokra? Ugyan a BT-határozat megerősíti azt, hogy az együttmúködés tekintetében a nem részes államokra a statútum semmiféle kötele-

484 A határozat eredeti nyelven elérhetô: https:/www.icc-cpi.int/NR/rdonlyres/85FEBDiA-29F8-4EC4-9566-48E DF55CC587/283244/N0529273.pdf [Letöltve: 2020. 01. 27.]. 
zettséget nem ró, de Szudánt külön megnevezve kiemeli e körből. A határozat szövegének nyelvtani értelmezéséből kiindulva pedig sem az állam „megváltozott” jogállása mellett, sem ellene nem lehet megalapozottan érvelni.

A normaszövegből levonható következtetéseket összegezve megállapítható, hogy a határozat megfogalmazása a hatékonyság szempontját figyelembe véve nem szerencsés. A nemzetközi közösség valamennyi, vagy legalább a Római Statútumban részes államainak említése azért lett volna normatív szempontból célszerü, mert így a nevesített államoknak az ENSZ Alapokmány 103. cikkére visszavezethető kötelezettsége lett volna adott esetben a jogsegély nyújtása, amely minden más szerződéses normából eredő nemzetközi kötelezettséggel szemben egyértelmúen primátust élvezett volna, ráadásul elejét vehette volna több jogértelmezési probléma kialakulásának. Másfelól a határozat semmiféle támogató (follow-up) mechanizmust nem biztosít az ICC részére, és ezt a határozat utólete is alátámasztotta: a bíróság a BT által elé terjesztett helyzetekkel magára maradt mind anyagi, mind politikai szempontból. ${ }^{485}$

\subsubsection{Azállamföi immunitás és az együttmüködési kötelezettség a Római Statútumban}

A Római Statútumot illetôen elsőként a - már korábban is idézett - 27. cikk bír a vizsgált témakör szempontjából kardinális jelentőséggel. A hivatalos minőség figyelmen kívül hagyása a büntetôjogi felelősség szempontjából - mely címet a 27. cikk is viseli - összecseng a nürnbergi Nemzetközi Katonai Törvényszék joggyakorlatával, illetve a nemzetközi szokásjoggal. Az elvet elsőként a náci főbưnösök felelősségre vonása során mondták ki, és ma - mint az ún. nürnbergi elvek egyike - már vitathatatlanul a nemzetközi szokásjog részét képezi. ${ }^{486}$

A 27. cikk két, elsőre talán összecsengő, ám semmiképpen sem korrelatív ${ }^{487}$ kapcsolatban álló normát rögzít, melyek közül a cikk (1) bekezdése a hivatalos minőség figyelmen kívül hagyását tartalmilag büntető anyagi jogi szempontból szabályozza, azaz hogy egy

485 Trahan, 2013, 465-468. o.

486 1950-ben az ENSZ Közgyúlésének 177 (II) határozata felszólította a nemzetközi szokásjog kodifikációjáért és progresszív továbbfejlesztéséért felelős kisegítő szervét, a Nemzetközi Jogi Bizottságot, hogy gyüjtse össze a nemzetközi jog azon alapelveit, melyek a nürnbergi Nemzetközi Büntető Törvényszék gyakorlata fényében szokásjogi erővel rendelkeznek. Mivel a törvényszék chartájában szereplő nemzetközi büntetőjogi elvekről a KGY-ben megállapítást nyert, hogy szokásjogi természetűek, így az ILC-re csupán az a feladat várt, hogy foglalja őket össze és bocsássa a kész szövegtervezetet szavazásra. Lásd részletesen a Vöröskereszt Nemzetközi Bizottságának honlapját, elérhető: https://ihl-databases.icrc.org/ihl/INTRO/390 [Letöltve: 2020. 01. 24.]. 487 A korrelatív kapcsolat hiánya alatt azt értem, hogy az anyagi jogi előfeltétel szükséges előfeltétele az eljárásjoginak, ugyanakkor az anyagi jogi előfeltétel fennállása nem vonja maga után az eljárásjogi feltételt, és az eljárásjogi feltételből nem következtethetünk az anyagi jogi feltételre. 
hivatalos minőségú elkövető büntető anyagi jogi felelőssége is okvetlenül fennáll az ICC előtt. A 27. cikk (1) bekezdése szerint: „A jelen Statútum a hivatalos minőségre való tekintet nélkül egyaránt vonatkozik minden személyre. Semmilyen körülmények között sem mentesíti az adott személyt a jelen Statútum szerinti büntetőjogi felelôsség alól különösen az állam-vagy kormányföi tisztséggel, kormány-vagy parlamenti tagsággal, választott képviselői vagy kormányhivatalnoki tisztséggel járó hivatalos minőség, és mint olyan, nem indokolja a büntetés mérséklését." E norma személyi hatálya az állami tisztviselőkre vonatkozik azzal, hogy a felsorolás nem kimerítő jellegư. ${ }^{488} \mathrm{Az}$ ún. funkcionális immunitásra összpontosító rendelkezés célja, hogy valamennyi állami tisztviselőt lefedjen, nem pusztán azokat, akiket expressis verbis meg is említ. ${ }^{489}$

Ezzel szemben a 27. cikk (2) bekezdése a hivatalos minőségében cselekvő elkövető felelősségét büntető eljárásjogi perspektívából közelíti meg: „A nemzeti vagy a nemzetközi szabályok szerint a hivatalos minőséggel járó mentességek vagy különleges eljárási szabályok nem akadályozzák a Bíróságot az adott személy fölöttjoghatóságának gyakorlásában." A rendelkezés tehát azt rögzíti, hogy az immunitás a büntetőeljárás megindításának nem szabhat gátat, másképpen szólva megteremti az ICC joghatóság-gyakorlásának procedurális alapját. ${ }^{490}$ A Római Statútum egyik kommentárjában William Schabas kiemeli, hogy a 27. cikk (2) bekezdése értelmében valamennyi nemzetközi szokásjogi mentesség is irrelevánssá válik, mivel a jogszabályhely egyaránt utal a nemzeti és nemzetközi szabályokra. ${ }^{491}$

A 27. cikket mint a Római Statútum részes feleinek állami tisztviselőit megillető mentességeket eltörlő normát kell értelmezni. ${ }^{492} \mathrm{~A}$ statútumhoz való csatlakozással az állam hozzájárul ahhoz, hogy az ICC joghatóságot gyakoroljon tisztviselői felett, azaz kettejük (a bíróság és az állam) relatív viszonyában az immunitásról feltételesen lemondott. Claus Kreß és Kimberly Prost a Triffterer-féle kommentárban, ${ }^{493}$ valamint Schabas saját kommentárjában ${ }^{494}$ arra a következtetésre jut, hogy a részes államok egymás közötti jogviszonyukban - azaz „horizontálisan” - is lemondanak az immunitásról, amit a hivatkozott szerzők arra alapoznak, hogy a nemzetközi elfogatóparancsok végrehajtása ellenkező esetben számos alkalommal ellehetetlenülne, a rendelkezés pedig kiüresedne. A fentivel ellentétes értelmezést Akande is aggályosnak véli, különösen a 27. cikk 98. cikk (1) bekezdéssel való párhuzamos alkalmazásának eseteiben (részletesen lásd lentebb). ${ }^{495}$

488 Triffterer, 2008, 779-793. o.

489 Gaeta, 2002, 975-1001. o.

490 Triffterer, 2008, 791. o.

491 Schabas, 2010, 446-453. o.

492 Kreß és Prost, 2008, 1601-1619. o.

493 Kreß és Prost, 2008, 1607. o.

494 Schabas, 2010, 450. o.

495 Akande, 2004, 420. o. 
Mivel a monográfia soron következő részei egy olyan probléma bemutatására tesznek kísérletet, ami egy nem részes állam sajátja, így külön kell szólni a 27. cikk alkalmazhatóságáról harmadik államok viszonylatában. A főszabály itt is az, amit az 1969. évi bécsi egyezmény 34. cikke rögzít, azaz hogy a Római Statútum a nem részes felek vonatkozásában sem jogokat, sem kötelezettségeket nem hoz létre, a statútum részes államai egy harmadik fél állami tisztviselőjének mentességéről értelemszerüen nem mondhatnak le. ${ }^{496}$

Mi a helyzet azonban akkor, ha e harmadik állam hivatalban lévő tisztviselője a Biztonsági Tanács határozata útján kerül a Nemzetközi Büntetőbíróság elé? Hogyan kell értelmezni ilyen esetekben a 27. cikket? A kérdésről a tárgyalás-előkészítő tanács elsóként akkor foglalt állást, amikor 2009-ben al-Bashír ellen az első nemzetközi elfogatóparancsot kibocsátotta. A kamara konklúziója az volt, hogy a szudáni államfó nem élvez immunitást az ICC előtt. ${ }^{497} \mathrm{~A}$ tárgyalás-előkészítő tanács teleologikus értelmezést alkalmazva egyrészt hangsúlyozta, hogy a Római Statútum elsődleges célja, hogy a nemzetközi bủntettek elkövetôi büntetlenségének véget vessen. ${ }^{498}$ Másrészt következtetését arra alapozta, hogy hivatalos minőségre való tekintet nélkül a statútumot minden terheltre nézve alkalmazni kell, a hivatalos minőség büntetőjogi felelősség akadályát nem képezheti, a büntetés enyhítését nem eredményezheti, és a Nemzetközi Büntetőbíróságot eljárásában semmi esetre sem akadályozhatja. ${ }^{499} \mathrm{~A}$ kamara arra is rávilágított, hogy a 21. cikk (1) bekezdés a) pontja ${ }^{500}$ értelmében a bíróságnak a Római Statútumot valamennyi előtte lévő ügyben alkalmaznia kell, így harmadik államok BT által előterjesztett helyzeteiben is..$^{501}$

A bíróság ezen határozata megosztja a kommentátorokat. Schabas azon az állásponton van, hogy a kamara a 27. cikket helytelenül értelmezte, mivel az 1969. évi bécsi egyezmény 34. cikkét ${ }^{502}$ nem hagyhatta volna figyelmen kívül. ${ }^{503} \mathrm{Kreß}$ és Gaeta más véleményt képviselnek. Előbbi szerző szerint a 27. cikk (2) bekezdést harmadik államokra is alkalmazni kell akkor, amikor a BT utal egy nem részes felet az ICC elé azért, mert ilyenkor a harmadik állam

496 Schabas, 2010, 450 . o.

497 Warrant of Arrest for Omar Hassan Ahmad Al Bashir, The Prosecutor v. Omar Hassan Ahmad al-Bashir, ICC02/05-01/09, Pre-Trial Chamber I, 4 March 2009, \$41 (a hivatkozásokban a továbbiakban: elsỏ letartóztatási parancs al-Bashír ellen).

498 Elsőletartóztatási parancs al-Bashír ellen 42. \$.

499 Elsőletartóztatási parancs al-Bashír ellen 43. \$.

500 Római Statútum 21. cikk (1) bekezdés a) pont: „A Bíróság a következőket alkalmazza: Elsősorban a jelen Statútumot, a Büncselekmények Tényállási Elemeit, továbbá az Eljárási és Bizonyítási Szabályokat."

501 Elsőletartóztatási parancs al-Bashír ellen 44. \$.

502 1969. évi bécsi egyezmény 34. cikk: „A szerződés harmadik állam számára-annak beleegyezése nélkül-sem kötelezettségeket, sem jogokat nem hoz létre."

503 Schabas, 2010, 451. o. 
analógia útján részes állami jogállásba kerül. ${ }^{504}$ Gaeta szintén alkalmazhatónak tartja a rendelkezést harmadik államokra is, azonban a tárgyalás-elôkészítő tanács határozatban levezetett érvelését nem tartja meggyőzőnek. ${ }^{505}$

Két évvel később a tárgyalás-előkészítő tanács ismét foglalkozott ugyanezzel a kérdéssel a Malawit a bírósággal való együttmúködés hiánya miatt elmarasztaló határozatában. ${ }^{506} \mathrm{E}$ döntésében a kamara megerősítette álláspontját, miszerint al-Bashír nem élvez immunitást a Nemzetközi Büntetôbíróság előtt. ${ }^{507}$ Ami sajnálatos a határozat kapcsán, hogy érvelése meglehetôsen gyenge lábakon áll, ezért a szakirodalomban sok támadás érte. A bírák indokolásukat részint az ICTY és ICTR statútumaira alapozták, annak ellenére, hogy a két ad hoc törvényszék statútuma nem törölte el expressis verbis az állami tisztviselők immunitását, míg a Római Statútum 27. cikke igen. A kamara a Yérodia-ügyben hozott obiter dictumra is kitér, miszerint hivatalban lévő magas rangú állami tisztviselők „néhány” nemzetközi büntetőbíróság előtt felelősségre vonhatók, beleértve e csoportba az ICC-t is. ${ }^{508} \mathrm{~A}$ határozat Antonio Cassese álláspontját is idézi, mely szerint a személyes immunitás mögötti ok függ attól, hogy nemzeti vagy nemzetközi büntetőbíróság eloott folyik eljárás. ${ }^{509} \mathrm{Az}$ eljáró tanács szerint a 27. cikk nemzetközi szokásjogi normát foglal írásba, nemcsak a funkcionális, hanem a személyes immunitás tekintetében is. Ennek kapcsán a nemzetközi büntetőjogi szakirodalom nem jutott még nyugvópontra: nem lehet teljes bizonyossággal kimondani, hogy a személyes immunitás terén a szokásjog fennállásának feltételei fennállnak. A tárgyalás-előkészítő tanács határozatai azt a meggyőződést tükrözik, hogy a nemzetközi bűncselekmények személyes immunitás alóli kivételt hoznak létre. A mérleg serpenyőjébe az ICC fellebbviteli tanácsa rakott némi ellensúlyt, amikor Jordániát elmarasztalta al-Bashír le nem tartóztatása miatt 2019 májusában, és kimondta, hogy a nemzetközi bíróságok előtti eljárások esetén nem lehet immunitásra hivatkozni. ${ }^{510}$

A jogi kontúrok felvázolása érdekében másodikként a Római Statútum Nemzetközi együttműködés és jogsegély címú IX. fejezetéből kell néhány rendelkezést kiemelni. Az államok együttmúködése a nemzetközi jog egyik alapelveként definiálható, és mivel

$504 \mathrm{Kreß}, 2012$, 223-265. o.

505 Gaeta, 2009, 315-332. o.

506 Decision Pursuant to Article 87(7) of the Rome Statute on the Failure by the Republic of Malawi to Comply with the Cooperation Requests Issued by the Court with Respect to the Arrest and Surrender of Omar Hassan Ahmad Al Bashir, The Prosecutor v. Omar Hassan Ahmad Al Bashir, ICC Pre-Trial Chamber I, ICC-02/0501/09-140-tENG, 12 December 2011 (a hivatkozásokban a továbbiakban: Malawi-határozat).

507 Malawi-határozat 36. \$.

508 Malawi-határozat 33. \$.

509 Malawi-határozat 34. \$.

510 Judgment in the Jordan Referral re Al-Bashir Appeal, The prosecutor v. Omar Hassan Ahmad Al-Bashir, ICC02/05-01/09-397, ICC Appeals Chamber, 6 May 2019 (a hivatkozásokban a továbbiakban: Jordánia-itélet). 
az ICC - a modern nemzetközi büntető igazságszolgáltatás történetében nem egyedülálló módon $^{511}$ - saját végrehajtó apparátussal nem rendelkezik, ezen elv a Nemzetközi Büntetőbíróság esetében különös jelentőséggel bír:512 ha a bíróság döntéseinek érvényt akar szerezni, akkor az államok együttmúködéséhez, külső segítséghez kell folyamodnia. A IX. fejezet eljárástechnikai, dokumentációs és titokvédelmi szabályokat is rögzít, valamint az Interpollal és egyéb nemzetközi szervezetekkel való együttmúködés mellett rendezi a nem részes államokkal való együttmúködés legkézenfekvőbb esetét is, melyet ad hoc megállapodás formájában irányoz elô. ${ }^{513}$ Ezek közül az alábbiakban csupán a vizsgált probléma megértéséhez feltétlenül szükséges szabályok sorakoztatnak fel.

Először is a Római Statútum 86 . cikke, ${ }^{514}$ mely kimondja a részes államok általános együttmúk ködési kötelezettségét; a 87. cikk (1) bekezdése, ${ }^{515}$ mely rögzíti ennek technikai szabályait; továbbá a 87 . cikk (5) bekezdése, ${ }^{516}$ mely felvázolja a statútumban nem részes államok együttmúködésének lehetőségét is: az ICC valamennyi államtól - tehát eseti megállapodás vagy egyéb nemzetközi szerződés alapján a nem részes államoktól is - jogosult határozatainak végrehajtásához segítséget kérni. Az együttmúködési kötelezettség elmulasztásának lehetséges jogkövetkezményeit a 87. cikk (7) bekezdése $e^{517}$ tartalmazza. A bíróság a kötelezettség teljesítésének elmaradásáról határozatot hozhat és értesítheti a Részes Államok Közgyúlését, vagy ha a Biztonsági Tanács utalta a szóban forgó helyzetet az ICC elé, akkor az „incidensről” a BT-t is tájékoztathatja. A megengedő megfogalmazásból következtethetünk a normák diszpozitív természetére, és az is kimondható, hogy az e rendelkezésben foglalt szankciók sem súlyosnak, sem önkéntes jogkövetésre motivá-

511 Az ENSZ ad hoc törvényszékei sem rendelkeztek saját végrehajtó szervekkel. Lásd erről bővebben: Cryer et al., 2016, 509-530. 0 .

512 Kovács, 2019b, 90. 0.

513 Kovács, 2019b, 87. o.

514 Római Statútum 86. cikk: „A Részes Államok a jelen Statútum rendelkezéseinek megfelelöen teljes mértékben együttmüködnek a Bírósággal a Bíróság joghatóságába tartozó büntettek miatti nyomozás és büntetőeljárás során."

515 Római Statútum 87. cikk (1) bekezdés a) pont: „A Bíróság jogosult a Részes Államok együttmúködését kérni. A megkereséseket diplomáciai úton vagy más olyan megfelelő módon továbbítják, amelyet a Részes Államok a megerōsítéskor, az elfogadáskor, a jóváhagyáskor vagy a csatlakozáskor megjelölnek. A megjelölést késóbb a Részes Államok az Eljárási és Bizonyítási Szabályoknak megfelelően módosítják."

516 Római Statútum 87. cikk (5) bekezdés: „a) A Bíróság felkérhet olyan Államot is, amely a jelen Statútumnak nem részese, hogy a jelen Fejezetnek megfelelően eseti megállapodás, vagy az Állammal kötött nemzetközi szerződés alapján, illetve bármely más megfelelö alapon segítséget nyújtson.

b) Amennyiben a Statútumban nem részes Állam, amely eseti megállapodást vagy nemzetközi szerződést kötött a Bírósággal, nem teljesíti a megállapodás vagy a nemzetközi szerződés szerint benyújtott kérelmeket, a Bíróság értesíti erről a Részes Államok Közgyülését, vagy ha a Biztonsági Tanács utalta a Bíróság elé az ügyet, a Biztonsági Tanácsot."

517 Római Statútum 87. cikk (7) bekezdés: „Ha a Részes Állam a jelen Statútum rendelkezéseivel ellentétben nem tesz eleget az együttmüködés iránti megkeresésnek, és ezzel akadályozza a Bíróságot a jelen Statútumban meghatározott feladatai és jogosítványai gyakorlásában, a Bíróság határozatot hozhat errōl, és a kérdést a Részes Államok Közgyülése elé terjeszti, illetve ha Biztonsági Tanács utalta az ügyet a Bíróság elé, a Biztonsági Tanács elé utalhatja az ügyet.” 
lónak nem nevezhetők. Kiemelésre tart még számot a 89. cikk (1) bekezdése, ${ }^{518}$ mely arról rendelkezik, hogy az ICC jogosult attól az államtól a vádlott letartóztatását és átadását kérni, melynek a területén a terhelt tartózkodik. Vélelmezhető, hogy mivel utóbbi rendelkezés az együttmúködés szükségszerúségének egyik konkrét esetét nevezi meg, így különös relevanciával bír.

Végül, de nem utolsósorban a Római Statútum 98. cikk (1) bekezdésében foglaltakat érdemes alaposabban megvizsgálni, amelynek lényege, hogy az ICC nem terjeszthet elő olyan átadás vagy jogsegély iránti kérelmet, amely a megkeresett államot olyan cselekményekre kényszerítené, amelyek ellentétesek lennének annak nemzetközi jogi kötelezettségeivel. A 98. cikk (1) bekezdés tehát olyan helyzetekben alkalmazandó, amikor a Római Statútum valamely részes állama harmadik államokkal szemben fennálló nemzetközi jogi kötelezettségeit - így a nemzetközi szokásjogon alapuló diplomáciai mentességet - sértené meg akkor, ha a bírósággal együttműködne. E szakasz két további magyarázatra szorul. Az egyik, hogy a „nemzetközi jogi kötelezettség” nemzetközi szerződésen, szokásjogon vagy általános jogelven alapulhat, ${ }^{519}$ ám a szerződésen alapuló mentességre nem a 98. cikk (1) bekezdésének, hanem (2) bekezdésének szabályai lesznek irányadók. A másik, hogy a rendelkezés teleologikus értelmezése tükrében pontosítani kell, mit ért a 98. cikk (1) bekezdése "harmadik állam” alatt? Ugyanis amíg a 98. cikk (2) bekezdése „küldő államot” említ, szembetûnő, hogy a 98. cikk (1) bekezdése nem ezt teszi. Az 1969. évi bécsi egyezmény 2. cikk (1) bekezdés h) pontja értelmében a főszabály az, hogy „a »harmadik állam « olyan államot jelent, amely nem részese a szerződésnek”. Azonban e norma diszpozitív tartalmú, ezáltal a szerződéskötő felek eltérhetnek tőle - mint ahogyan az a 98. cikk (1) bekezdése esetében is történt. A többségi szakirodalmi álláspont tükrében itt „harmadik állam” alatt olyan államot kell érteni, ami nem a megkeresett állam. ${ }^{520}$ Ennek fényében a 98. cikk (1) bekezdése szerinti „harmadik állam” akár egy, a Római Statútumban részes állam is lehet, ugyanakkor megjegyzendő, hogy ezen államok a 27. cikk (2) bekezdése alapján a diplomáciai mentességekről lemondtak, ezért a vizsgált probléma esetükben nem releváns.

Ha azonban a jelen cikk szerinti „harmadik állam” a Római Statútumnak nem részes állama, egymásnak ellentmondó kötelezettségek kereszttüzébe kerülhet. Amennyiben

518 Római Statútum 89. cikk (1) bekezdés: „A Bíróság bármely olyan Államnak előterjeszthet személyek letartóztatására és átadására irányuló megkeresést, a kérelem alátámasztására szolgáló, a 91. cikkben meghatározott anyagokkal együtt, amelynek területén az adott személy található, és az adott Állam együttmüködését kéri az adott személy letartóztatása és átadása érdekében. A Részes Államok a jelen Fejezet rendelkezései és nemzeti eljárási szabályaik szerint teljesítik a letartóztatás és az átadás iránti kérelmet."

519 Schabas, 2010, 1040-1041. o.

520 Kreß és Prost, 2008, 1606. o.; Schabas, 2010, 1039. o. 
az ICC megkeresése és a megkeresett állam „harmadik állammal” szembeni kötelezettsége között normakonfliktus alakul ki, akkor azt a nemzetközi szokásjog alapján kell elbírálni. ${ }^{521}$ Mint ahogyan az a következő pontban olvasható, a szokásjog az immunitásnak két fajtáját ismeri, melyek a funkcionális immunitás és a személyes immunitás: az első az állam nevében eljáró tisztviselőket védi, a másik pedig a magas rangú állami tisztviselőket. Ma már egyértelmú - és ezt tükrözi a Római Statútum 27. cikk (2) bekezdése is -, hogy a funkcionális immunitás nem vonhatja ki az egyént a nemzetközi büncselekményekért való felelősség alól. Ezzel szemben a személyes immunitás megítélése a szakirodalomban vitatott.

Amikor egy részes államot az ICC megkeres együttmúködés céljából, az felvetheti a fennálló „nemzetközi jogi kötelezettségek” megsértésének lehetőségét. Hogy ez valóban felmerül-e vagy sem, attól függ, hogy erre a „végrehajtó” részes államra úgy tekintünk, mint amelyik saját, vagy úgy, mint amelyik az ICC nevében jár el, annak joghatóságát gyakorolja. A tárgyalás-elókészítő tanács szerint ezen államok az ICC végrehajtó apparátusaként járnak el, ami lehetôvé teszi, hogy együttmúködési kötelezettségüknek eleget tegyenek egyéb fennálló „nemzetközi jogi kötelezettségek” megsértése nélkül.

Összegezve tehát elmondható, az ICC az államok együttmúködése nélkül csupán „félkarú óriás", ${ }^{522}$ mivel saját rendőri, közigazgatási és büntetés-végrehajtási szervek hiányában önmaga nem képes saját döntéseinek végrehajtására. Ennek fényében, a Római Statútum részes államait - inkább kevesebb, semmint több sikerrel - arra kötelezi, hogy múködjenek közre a terheltek letartóztatása és az ICC-nek történő átadása tekintetében. A nemzetközi közösség számos esetben láthatott már az elfogatóparancs végrehajtásának elmulasztására példákat, amikor is a Római Statútum részes államai elmulasztották al-Bashír letartóztatását a 98. cikk (1) bekezdésére hivatkozva, holott az egykori szudáni államfó hivatalosan tartózkodott ezen államok területén. ${ }^{523}$

\subsubsection{Azállamföi immunitás a nemzetközi szokásjogban és a nemzetközi biróságok joggyakorlatában}

A szuverén egyenlőség elve a nemzetközi közjog egyik princípiuma, melyet az ENSZ Alapokmány 2. cikk (1) bekezdése írásba is foglal. ${ }^{524}$ Ezt az alapelvet két másik elvre bonthatjuk, melyek az állami szuverenitás és az államok (jogi) egyenlősége. ${ }^{525} \mathrm{~A}$ szuverén egyenlősége

521 Kreß és Prost, 2008, 1608. o.

522 Cassese, 1998, 13. o.

523 Tladi, 2015, 1028-1029. o.

524 ENSZ Alapokmány 2. cikk (1) bekezdés: „A Szervezet valamennyi tag szuverén egyenlőségének elvén alapszik.”

525 Kovács, 2016, 273-279. o. 
elvéből kiindulva továbbá bizonyos állami tisztviselők - akik államuk nevében járnak el immunitást élveznek a nemzetközi büntetőeljárásokkal szemben. A követ „szentsége” az államok közötti kapcsolatok egyik legősibb alapelve, melynek értelmében a diplomáciai képviselő személye ellen letartóztatás vagy őrizetbe vétel egyáltalán nem foganatosítható. ${ }^{526}$

A természetes személyeket megillető immunitásnak két fajtája van. ${ }^{527} \mathrm{Az}$ első kategória (i) bizonyos személyeket véd, azaz főképp az állami tisztségviselő magánszemélyi minőségének védelmére hivatott, ez az ún. személyes immunitás (ratione personae). A második kategória (ii) pedig bizonyos cselekményeket részesít védelemben, azaz az állami tisztségviselók hivatalos minőségben elkövetett cselekményeihez fưződik, ez az ún. funkcionális immunitás (ratione materiae).

A ratione personae immunitás lényege, hogy a privilegizált, magas rangú állami tisztviselők hivatalos missziójukat mindennemú zavaró körülménytől és beavatkozástól mentesen teljesíthessék, így a személyes immunitás speciális pozíciókhoz csatlakozik és csupán tisztviselők szúk körét védi.

A személyes immunitás legfőbb jellemzői közé tartozik, hogy (i) eljárásjogi jellegú védelmet biztosít - azaz az állami tisztségviselőt sérthetetlennek tekinti egy másik állam büntető joghatóságával szemben. (ii) Teljes mértékú sérthetetlenséget nyújt - azaz mind a hivatalos, mind a magánszemélyi minőségben elkövetett cselekmények esetén hivatkozható - még olyan cselekmények esetében is, amelyeket hivatalba lépése elött követett el a mentességet élvező személy. (iii) Csupán a Nemzetközi Bíróság által 2002-ben, a Yérodia-ügyben konkrétan nevesített tisztségviselőket védi: államfőket, kormányfőket, külügyi tárcáért felelős minisztereket, diplomatákat, valamint a nemzetközi szervezetekhez akkreditált képviselőket. ${ }^{528}$ (iv) A személyes immunitás a funkcionális immunitással ellentétben a hivatalos minőség megszúnésével véget ér, mely a jogintézmény céljából ered, tekintve, hogy esszenciája a hivatali tevékenység végzésének zavartalanságában rejlik. (v) Nem erga omnes hatályú norma, így például a diplomaták esetén csak a küldő, a fogadó és a tranzitállam vonatkozásában hivatkozható. ${ }^{529}$ Valamint hogy (vi) a nemzetközi bíróságok előtti alkalmazása a szakirodalomban sokáig tûrte a vitát, ám a többségi álláspont afelé tendál, hogy - a ratione materiae immunitáshoz hasonlóan (lásd alább) - erre sem lehet nemzetközi fórumok előtt hivatkozni.

526 Bába és Sáringer, 2018, 119. o.

$527 \mathrm{Az}$ immunitás jogintézményét a belső jog szintén ismeri és alkalmazza, így hazánkban sem ismeretlen e fogalom (mentelmi jog). Mindazonáltal a belső jog szintjén felmerülő immunitás kérdésével nem foglalkozom, mivel jelen téma szempontjából különösebb relevanciával nem bír. Lásd: Cassese, 2008, 302-303. 0., 314. o.

528 Yérodia-ügy $51-55$. \$.

529 Cassese, 2008, 302-304. o. 
Dapo Akande meglátása szerint a személyes immunitás nemzetközi büncselekmények esetén egyáltalán nem vehető figyelembe, ${ }^{530}$ és Antonio Cassese is hasonlóan vélekedik: „Öszszegezve: a nemzetközi szokásjog szerint az állami tisztségviselők személyes immunitása a nemzetközi biróságokat, illetöleg törvényszékeket nem gátolhatja meg abban, hogy a nemzetközi büncselekmények elkövetésével gyanúsitott, illetve vádolt személyek ügyében eljárjanak, ha az ügyben a szóban forgó bíróság, illetóleg törvényszék egyébként joghatósággal rendelkezik."531

E kérdés nyugvópontra helyezése felé az ICC fellebbviteli tanácsa 2019. május 6-án jelentős lépést tett, amikor elmarasztalta Jordániát az al-Bashír elleni elfogatóparancsok végrehajtásának elmulasztása miatt. Az ICC bírái a Jordánia-határozatban akként foglaltak állást, hogy a nemzetközi szokásjog nem biztosít személyes immunitást nemzetközi bíróságok vonatkozásában, ${ }^{532}$ és arra jutottak, hogy a bíróság eljárhat hivatalban lévő magas rangú állami tisztviselókkel szemben akkor, ha a Római Statútum nem részes államainak tisztviselỏi és ezen harmadik államok nem önként mondtak le az immunitásról.

A ratione materiae immunitás az „állam cselekménye” elméletében (act of State doctrine) gyökerezik és valamennyi tisztségviselőre alkalmazandó, aki állami kötelezettséget teljesít (nem magánjellegú szuverén aktusok). E teória szerint az a személy, aki egy szuverén állam nevében cselekszik, nemzetközi jogi jogsértésért elviekben nem vonható felelősségre addig, amíg e hivatalos minősége fennáll - így a mentessége megszúnéséig nemzetközi szinten kizárólag az állam vonható felelősségre.

A funkcionális immunitás legfóbb jellemzői között említhető, hogy (i) anyagi jogi természetư jogintézmény: habár az állami tisztségviselő kötelezett a nemzetközi közjog és a másik állam anyagi jogának betartására, ha mégis megsérti akár a nemzetközi, akár a belső jogot, ez a jogsértés nem neki, hanem az államának tudható be. (ii) Mind a de iure, mind a de facto állami tisztségviselőket védelemben részesíti. (iii) Az állami tisztség megszúnésével nem ér véget. (Ennek oka, hogy mivel a cselekmény jogilag az államnak tudható be, ha a hivatalos tisztség megszúnik, a felelősség az államot továbbra is terheli.) (iv) Valamint erga omnes természetû́ norma, ami azt jelenti, hogy bármelyik állammal szemben lehet jogszerúen hivatkozni rá.

A Nemzetközi Bíróság a Yérodia-ügyben hozott ítéletének obiter dictumában ${ }^{33}$ úgy érvelt, hogy az államfőknek járó funkcionális immunitás egy másik állammal szemben abszolút, és akkor is alkalmazandó, ha a terheltet nemzetközi büncselekmény elkövetésével vádolják: „nem vezethetô le a nemzetközi szokásjogból a büntető joghatóság alóli immunitásra, illetve sérthetet- 
lenségre vonatkozó kivétel, még arra az esetre nézve sem, ha a hivatalban lévő külügyminisztert háborús, illetve emberiesség elleni büntettek elkövetésével vádolják". ${ }^{534}$

Ezzel szemben Awn Shawkat Al-Khasawneh ${ }^{535}$ és Christine Van den Wyngaert ${ }^{536}$ bírák az ítélethez fúzzött különvéleményükben kifejtették, hogy meglátásuk szerint nemzetközi büncselekmények esetén a funkcionális immunitás sem nemzetközi, sem nemzeti szinten nem alkalmazandó. Dapo Akande szintén az ítélet különvéleményében kifejtettekkel ért egyet, ám meglátása szerint a Nemzetközi Bíróság az immunitás kérdését a személyes immunitás szemszögéből közelítette meg, így a fenti tételt is akként kell értelmezni. ${ }^{537}$ Cassese nemzetközi büntetójogi tankönyvében pedig arra a következtetésre jut, hogy a nemzetközi büntetőbíróságok előtt a funkcionális immunitás megszúnése - mint norma - szokásjogi szintre emelkedett, amit több precedenssel igyekszik alátámasztani. ${ }^{538}$

Ezek a következők. (i) Nem esetjogi példa, ám fontos, hogy a funkcionális immunitás nemzetközi bưncselekmények imperatívusza előtti meghajlása elsőként a nürnbergi Nemzetközi Katonai Törvényszék Chartájában érhetô tetten, miszerint az immunitás pajzsa többé nem védi meg a magas rangú állami tisztségviselőket a háborús bủntettek, illetőleg a béke és az emberiesség elleni bûncselekmények miatti felelősségre vonástól, mely az ún. nürnbergi elvek között harmadikként került felsorolásra. (ii) E kérdés eljáró bíróság előtt elsőként Adolf Eichmann volt SS-főtiszt, illetve a Nemzetiszocialista Német Munkáspárt vezető tagja ügyében merült fel, ${ }^{539}$ ahol az izraeli legfelsőbb bíróság egyértelműen arra az álláspontra helyezkedett, hogy a hivatalos minőségükben cselekvő állami tisztségviselők a nemzetközi bűncselekmények miatti felelősségre vonás alól a funkcionális immunitásra hivatkozva nem mentesülhetnek. (Itt azonban fontos kiemelni, hogy e példa a többihez képest kilóg a sorból, mivel az eljáró jeruzsálemi bíróság nem minősült nemzetközi bírói fórumnak, hanem egyetemes joghatóság alapján gyakorolt joghatóságot Eichmann felett.) (iii) Időrendben másodikként az ICTY joggyakorlatából hozhatunk fel példákat. Az ICTY

534 Yérodia-ügy 58. $\$$.

535 Concerning the Arrest Warrant of 11 April 2000 (Democratic Republic of Congo v. Belgium) Dissenting Opinion of Judge Al-Khasawneh, elérhetô: https://www.icj-cij.org/files/case-related/121/121-20020214-JUD-0107-EN.pdf [Letöltve: 2017. 01. 17.].

536 Concerning the Arrest Warrant of 11 April 2000 (Democratic Republic of Congo v. Belgium) Dissenting Opinion of Judge Van den Wyngaert, elérhető: https://www.icj-cij.org/files/case-related/121/121-20020214-JUD01-09-EN.pdf [Letöltve: 2017. 01. 17.].

537 Akande, 2009, 334. o.

538 Cassese, 2008, 305-306. o.

539 Attorney General v. Adolf Eichmann, Criminal Case No. 40/46, Judgment, District Court of Jerusalem, Israel, 11 December 1961, \$\$309-312. 
mind Radovan Karadžić ügyében, ${ }^{540}$ mind Anto Furundžija ${ }^{541}$ és Slobodan Milošević ügyében ${ }^{542}$ arra hivatkozott, hogy az ICTY Statútumának 7. cikk (2) bekezdése ${ }^{543}$ - amely a hivatalos minőség figyelmen kívül hagyásáról rendelkezik - szokásjogi erővel bír. Két évvel később a törvényszék a Krstić-ügyben hasonló konklúziót vont le: „Jóllehet [...], hogy az államok között a funkcionális immunitás ezen cselekmények tekintetében fennáll, de helytelen volna azt sugallni, hogy ezen immunitás nemzetközi büntetôbiróságok elött létezik". ${ }^{44}$ Mi több, az ICTY fellebbviteli tanácsa a Blaskić-ügyben ${ }^{545}$ már expressis verbis azzal érvelt, hogy a funkcionális immunitás nemzetközi bűncselekmények esetén a felelősség alól nem mentesít. (iv) Ugyanezt az álláspontot sajátította el az Egyesült Királyság Lordok Házának két bírája, Lord Millet és Lord Phillips, a volt chilei diktátor, Augusto Pinochet ügyében - párhuzamosan megjegyezve, hogy ebben az ügyben szintén nem nemzetközi büntetőbírói fórumról van szó -, ${ }^{546}$ csakúgy, mint (v) a SCSL a volt libériai elnök, Charles Taylor ${ }^{57}$ büntetőjogi felelőssége és a funkcionális immunitás kapcsolata vonatkozásában.

A funkcionális immunitás doktrínája a nemzetközi szokásjogban finoman csiszolódott az évek során a nemzetközi büntető igazságszolgáltatás hajnalától - a nürnbergi pertől napjainkig. A szokásjogi szabály alóli kivételként eközben kristályosodott ki az a tétel, hogy az állami tisztviselők nemzetközi bűncselekmények elkövetése esetén a funkcionális immunitásra nem hivatkozhatnak. ${ }^{548}$ Napjainkban az emberi jogok védelme és a nemzetközi bű́ncselekmények jogszerû megtorlása a nemzetközi közösség legfóbb prioritásai közé tartoznak, és ebből adódik az a fentebb felvázolt tendencia is, amely az állami szuverenitásból adódó tradicionális alapelvet, a funkcionális immunitás érvényesülését lerontja. ${ }^{549}$

540 Prosecutor v. Radovan Karadžić, IT-95-5/18-T, Judgment, International Tribunal for the Prosecution of Persons Responsible for Serious Violations of International Humanitarian Law Committed in the Territory of the Former Yugoslavia since 1991, The Hague, 24 March 2016, \$24.

541 Prosecutor v. Anto Furundžija, IT-95-17/1-T, Judgment, International Tribunal for the Prosecution of Persons Responsible for Serious Violations of International Humanitarian Law Committed in the Territory of the Former Yugoslavia since 1991, The Hague, 10 December 1998, \$140.

542 Prosecutor v. Slobodan Milošević, IT-02-54, Decision on the Preliminary Motions, 8 November 2001, \$28.

543 ICTY Statútum 7. cikk (2) bekezdés: „Valamennyi vádlott hivatalos pozíciója-akár államföi, kormányfói vagy felelös beosztású kormánytisztviselői-, sem e személy bünösségének, sem büntetésének megállapitása során enyhitő körülményként nem vehetófigyelembe."

544 Prosecutor v. Krstić, IT-98-33, Decision on Application of Subpoenas, I July 2003, \$26.

545 Prosecutor v. Tihomor Blaskić, IT-95-14-A, Judgment, International Tribunal for the Prosecution of Persons Responsible for Serious Violations of International Humanitarian Law Committed in the Territory of the Former Yugoslavia since 1991, The Hague, 29 July 2004, \$ 41.

546 Regina v. Bartle and the Commissioner of Police for the Metropolis and others ex parte Pinochet / Regina v. Evans and another and the Commissioner of Police for the Metropolis and others ex parte Pinochet, Opinions of the Lords of Appeal for Judgement in the Cause, House of Lords, 25 November 1998, \$\$ 171-179, \$\$186-190. 547 The Prosecutor v. Charles Ghankay Taylor, Case No. SCSL-03-01-A, Judgment, Special Court for Sierra Leone, The Hague, 26 September 2013, \$\$ 52-53 (a hivatkozásokban a továbbiakban: Taylor-ügy).

548 Kreß és Prost, 2008, 1608. o.

549 Cassese, 2008, 308. o. 


\subsection{A tárgyalás-elókészitő tanácsok határozatai az al-Bashír-ügyben}

Az ICC tárgyalás-előkészítő tanácsa al-Bashír ellen két letartóztatási parancsot bocsátott ki: ${ }^{50}$ az elsőben öt rendbeli emberiesség elleni bưntett és két rendbeli háborús búntett, a másodikban három rendbeli népirtás elkövetésével vádolják. Az ok, amiért a tárgyalás-elókészítő tanács két letartóztatási parancsot adott ki, hogy az elsőben - bizonyítékok hiányára hivatkozva - nem szerepelt a népirtás vádja. Ez ellen azonban 2010. február 3-án Luis Moreno-Ocampo fellebbezést nyújtott be, amit a bíróság fellebbviteli tanácsa elbírált, majd úgy határozott, hogy alapos gyanú áll fenn arra vonatkozóan, hogy al-Bashír közvetett tettes, illetve társtettes genocídium - a statútum által definiált első három elkövetési magatartásával megvalósított ${ }^{551}$ - elkövetésében. ${ }^{552} \mathrm{Az}$ eljáró tanács az al-Bashír elleni első letartóztatási parancs kibocsátásakor a Nemzetközi Büntetőbíróság Hivatalához az államfó letartóztatása és átadása iránt kérelmet nyúitott be azzal, hogy továbbítsák a megkeresést a Római Statútum valamennyi részes államának, valamint a Biztonsági Tanács azon tagjainak is, amelyek nem részes felek a statútumban.

A Római Statútum 86. cikke és 89. cikke alapján a szerződésben részes államok, amenynyiben a terhelt államterületükön tartózkodik, kötelesek letartóztatását foganatosítani és ôt a bíróságnak átadni. Ugyanakkor felmerült az a kérdés, hogy nem sértené-e meg fennálló nemzetközi jogi kötelezettségeit az a részes állam, amelyik az államfőt letartóztatná? Ugyanis Szudán nem részes fél a statútumban, és a szerződések relatív hatályának elvéből kiindulva egy szerződésben részes és nem részes állam vonatkozásában főszabály szerint a nemzetközi szokásjog normái irányadóak a szerződéses normákkal szemben. A nemzetközi szokásjog pedig az államfőket, kormányfóket, külügyminisztereket és diplomatákat mentességgel illeti meg a külföldi államok büntető joghatóság-gyakorlásával szemben. ${ }^{553}$ Eszerint, ha az államfő külföldön tartózkodik, sérthetetlennek kell tekinteni, így a külföldi állam büntetô joghatóságot nem gyakorolhat felette, amibe az is beletartozik, hogy egy másik állam rendôri szervei ôt nem tartóztathatják le.

550 Second Warrant of Arrest for Omar Hassan Ahmad Al Bashir, The Prosecutor v. Omar Hassan Ahmad Al Bashir, ICC-02/05-01/09, Pre-Trial Chamber I, 12 July 2010 (a hivatkozásokban a továbbiakban: második letartóztatási parancs al-Bashír ellen).

551 Római Statútum 6. cikk: „A jelen Statútum alkalmazásában a népirtás büntette alatt bármelyik következő cselekmény értendő, amelyet valamely nemzeti, etnikai, faji vagy vallási csoport, mint olyan, teljes vagy részleges megsemmisitésének szándékával követnek el:

a) csoport tagjainak megölése;

b) csoport tagjai testi vagy lelki épsége elleni súlyos sérelem okozása;

c) csoportnak szándékosan olyan életfeltételek közé kényszeritése, amelyek a csoport teljes vagy részleges fizikai megsemmisülését okozhatják."

552 Második letartóztatási parancs al-Bashír ellen 6. \$.

553 Akande, 2004, 407-409. o. 
Ahhoz tehát, hogy valamelyik állam az ICC által kiadott elfogatóparancsot jogszerúen végrehajthassa, valamint al-Bashírt - államfôként - jogszerủen letartóztathassa, illetve a bíróságnak átadhassa, elengedhetetlen, hogy a nemzetközi szokásjog által támasztott akadályt valamilyen más jogforrásból származó norma - mint lex specialis - lerontsa. A letartóztatást elrendelő határozatban a tárgyalás-előkészítő tanács al-Bashír mentességére csak implicite tért ki, a mögötte meghúzódó okfejtésre azonban már egyáltalán nem: „al-Bashír jelenlegi pozíciója - azaz hogy egy Statútumban nem részes állam államföje - jelen ügyben a Bíróság joghatóságára nézve semmiféle kihatással nem bír". ${ }^{554}$ E tétel kimondásakor a tárgyalás-előkészítô tanács figyelembe vette a Római Statútum Preambulumában megfogalmazott legfontosabb célkitúzést, miszerint a nemzetközi közösség egészét érintő legsúlyosabb bủntettek nem maradhatnak büntetlenül.555 Továbbá a tárgyalás-előkészítő tanács a joghatóság gyakorlásának jogszerúségét arra alapozta, hogy amikor a Biztonsági Tanács a dárfúri helyzetet az ICC elé utalta, akkor azt is elfogadta, hogy a konfliktus feltárásához kapcsolódó nyomozás - csakúgy, mint az azt követő esetleges büntetőeljárás - a statútum által biztosított jogszabályi keretek között zajlik majd..$^{556}$

Ellenben annak általános elismerése, hogy a bíróság joghatóságot gyakorolhat hivatalban lévő államfók felett, illetve annak kimondása, hogy az államfők nem hivatkozhatnak a mentességre az ICC elôtt, még önmagában véve nem oldja meg az immunitás-problémát. Ahhoz ugyanis, hogy a bíróság egy vádlottat ôrizetbe vehessen, szükség van a gyakorlatban egy olyan végrehajtó államra, mely a terheltet előzetesen letartóztatja. Ebből adódóan a mentesség kérdése valójában úgy merül fel, hogy lehet-e hivatkozni az immunitásra a letartóztatási parancsot végrehajtó állam hatóságaival szemben? (A Nemzetközi Bíróság elôtt lezajlott Yérodia-ügyboől ${ }^{57}$ kiindulva az immunitás egy másik állam hatósága szemszögéből a vádlottal szembeni büntethetőségi akadályként merül fel. ${ }^{558}$ )

A tárgyalás-előkészítő tanács a letartóztatási parancs kibocsátásakor az állami szinten érvényesülő immunitást nem vette figyelembe, mint ahogyan a statútum 27. cikk és 98 . cikk (1) bekezdésének kapcsolatáról sem tett említést. E mulasztás komoly hiányosságként róható a terhére, mert a fennálló szokásjogi kötelezettségek teljes mértékben indokolták volna az eljáró tanács részéről a jogi állásfoglalást, valamint a tôlük való eltérés indokolását is. E tekintetben a tárgyalás-előkészítő tanács két lehetséges megközelítés közül választhatott volna: (i) az első, hogy elismeri ugyan, hogy a 27. cikk eltörli az immunitást az ICC tekinte-

554 Második letartóztatási parancs al-Bashír ellen 41. \$.

555 Akande, 2004, 336. o.

556 Második letartóztatási parancs al-Bashír ellen 45. \$.

557 Yérodia-ügy 51-55. \$\$.

558 Cryer et al., 2016, 547. o. 
tében, azonban a 98. cikk (1) bekezdés továbbra is megőrzi őket az egyes államok vonatkozásában; (ii) a második pedig, hogy a 27. cikk nemcsak a bíróság, hanem az egyes államok szintjén is eltörli az immunitást azokban az esetekben, amikor az állami hatóságok az ICC nevében járnak el.

Teljes mértékben egyet lehet érteni Dapo Akande álláspontjával, aki szerint, ha a 27. cikket csak az ICC szintjén alkalmaznánk, akkor - figyelembe véve az ICC előtt potenciálisan felelősségre vonandó személyi kört - a benne foglalt rendelkezések súlytalanná válnának. Mivel a bíróságnak nincsenek önálló végrehajtó szervei, így az első álláspont elismerése a 27. cikk kiüresedését vonná maga után. Ez esetben ugyanis a nemzetközi bưncselekmény elkövetésével vádolt, ámde mentességet élvező vádlott csak abban az esetben kerülhetne az ICC elé, ha önkéntesen feladná magát a büntetőbírói fórum előtt. Könnyedén belátható, hogy utóbbi gyakorlati realitása igencsak csekély, így egy olyan rendelkezés válna abszolút impotenssé, amelyik főszerepet tölt be a büntetlenség elleni harcban és a Római Statútum rezsimjében, végső soron pedig a hatékonyság elvének gyakorlati megvalósulásában. ${ }^{59}$ A kritikai élú megjegyzések számát csak tovább gyarapítja, hogy a tárgyalás-előkészítő tanács az itt felsorolt jogi problémákat a második letartóztatási parancsról hozott határozatban sem tisztázta.

Fatou Bensouda a dárfúri helyzetről szóló 2019. decemberi jelentésében ${ }^{560}$ üdvözölte a Szudánban végbement közelmúltbeli eseményeket, és hangsúlyozta, hogy reményekkel telve tekint az ICC és az ország jövőbeli „komplementer” együttmúködése elé. Ugyanakkor az a megállapítás, miszerint az ICC a nemzetközi büntető igazságszolgáltatásban ráosztott szerepet - az államok együttmúködési kötelezettségének sorozatos elmulasztása miatt - ez idáig nem volt képes betölteni, továbbra is helytálló marad.

$\mathrm{Az}$ „együtt nem múködési eljárás” jellemzően úgy indul, hogy a Fôügyészi Hivatal vagy az ICC Hivatala a médián keresztül tudomást szerez al-Bashír jövőbeli látogatásáról valamely részes államba. Ezután jelentést küld a hatáskörrel rendelkező tárgyalás-előkészítő tanácsnak és az ICC hivatalvezetőjének, aki szóbeli figyelmeztetést intéz az illetékes hágai nagykövetségeken keresztül a helyi hatóságok felé. Mivel ez rendszerint nem vezet eredményre, a következő lépéseket már utólagosan az eljáró tárgyalás-elókészítő tanács teszi meg: határozatot hoz, amelyben felszólítja a helyi hatóságokat, hogy adják ki hivatalos állásfoglalásukat a szudáni államfő közelmúltbeli látogatásáról.

559 Akande, 2004, 337-338. o.

560 Thirtieth Report of the Prosecutor of the International Criminal Court to the United Nations Security Council Pursuant to UNSCR 1593 (2005), elérhető: https://www.icc-cpi.int/test-new-master/Pages/pr-new.aspx?name=2019-12-19-otp-stat-UNSC-sudan [Letöltve: 2020 . 01. 25.]. 
A szudáni helyzet bíróság elé kerülése óta az ICC tárgyalás-elókészítő kamarái számos alkalommal hoztak olyan határozatot, melyek kimondták Szudán vagy valamelyik Római Statútumban részes állam együttmúködési kötelezettségének elmulasztását, illetve indítványozták az al-Bashir és egyéb körözött személyek letartóztatásában együtt nem múködő államok elleni szükséges intézkedések megtételét, és több esetben az eljáró tárgyalás-előkészítő tanács értesítette a Részes Államok Közgyúlését, illetve a Biztonsági Tanácsot. E határozatok kronológiai sorrendben az alábbiak.

A tárgyalás-előkészítő tanács (Pre-Trial Chamber I) elsőként Csád ${ }^{561}$ és Kenya ${ }^{562}$ együtt nem múködéséről informálta a Biztonsági Tanácsot és a Részes Államok Közgyúlését 2010. augusztus 27-én, ezt követte Dzsibuti ${ }^{53}$ 2011. május 12-én. Az első marasztaló döntés Malawival szemben született 2011. december 12-én (lásd fentebb), egy nappal később pedig Csáddal ${ }^{564}$ szemben látott hasonló döntés napvilágot. Utóbbi ellen még egy második marasztaló döntést ${ }^{565}$ hozott a bíróság 2013. március 26 -án. A bíróság egy másik tárgyalás-előkészítő tanácsa (Pre-Trial Chamber II) 2013. szeptember 5-én Nigériát ${ }^{566}$ szólította fel együttmúködésre, majd 2014. április 9-én újabb marasztaló döntést adtak ki - a Biztonsági Tanács és az ASP értesítésének kíséretében -, ezúttal a Kongói Demokratikus Köztársaság ${ }^{567}$ ellen.

561 Decision informing the United Nations Security Council and the Assembly of the States Parties to the Rome Statute about Omar Al Bashir's recent visit to the Republic of Chad, The Prosecutor v. Omar Hassan Ahmad Al Bashir, ICC-02/05-01/09-109, ICC Pre-Trial Chamber I, 27 August 2010 (a hivatkozásokban a továbbiakban: I. Csád-határozat).

562 Decision informing the United Nations Security Council and the Assembly of the States Parties to the Rome Statute about Omar Al Bashir's presence in the territory of the Republic of Kenya, The Prosecutor v. Omar Hassan Ahmad Al Bashir, ICC-02/05-01/09-107, ICC Pre-Trial Chamber I, 27 August 2010 (a hivatkozásokban a továbbiakban: Kenya-határozat).

563 Decision informing the United Nations Security Council and the Assembly of the States Parties to the Rome Statute about Omar Al Bashir's recent visit to Djibouti, The Prosecutor v. Omar Hassan Ahmad Al Bashir, ICC-02/05-01/09-129, ICC Pre-Trial Chamber I, 13 May 2011 (a hivatkozásokban a továbbiakban: I. Dzsibuti-határozat).

564 Decision pursuant to article 87(7) of the Rome Statute on the refusal of the Republic of Chad to comply with the cooperation requests issued by the Court with respect to the arrest and surrender of Omar Hassan Ahmad Al Bashir, The Prosecutor v. Omar Hassan Ahmad Al Bashir, ICC-02/05-01/09-140-tENG, ICC Pre-Trial Chamber I, 13 December 2011 (a továbbiakban a hivatkozásokban: II. Csád-határozat).

565 Decision on the Non-compliance of the Republic of Chad with the Cooperation Requests Issued by the Court Regarding the Arrest and Surrender of Omar Hassan Ahmad Al Bashir, The Prosecutor v. Omar Hassan Ahmad Al Bashir, ICC-02/05-01/09-140-151, ICC Pre-Trial Chamber II, 26 March 2013 (a hivatkozásokban a továbbiakban: III. Csád-határozat).

566 Decision on the Cooperation of the Federal Republic of Nigeria Regarding Omar Al Bashir's Arrest and Surrender to the Court, The Prosecutor v. Omar Hassan Ahmad Al Bashir, ICC-02/05-01/09-159, ICC Pre-Trial Chamber II, 5 September 2013 (a hivatkozásokban a továbbiakban: Nigéria-határozat).

567 Decision on the Cooperation of the Democratic Republic of the Congo Regarding Omar Al Bashir's Arrest and Surrender to the Court, The Prosecutor v. Omar Hassan Ahmad Al Bashir, ICC-02/05-01/09-195, ICC Pre-Trial Chamber II, 9 April 2014 (a hivatkozásokban a továbbiakban: DRC-határozat). 
Az ICC tárgyalás-előkészítő tanácsa következőként Dzsibutit ${ }^{568}$ és Ugandát ${ }^{569}$ marasztalta el 2016. július 11-én, majd a Dél-afrikai Köztársaságot 2017. július 6-án,, âm utóbbi incidenst nem terjesztette az ASP és a BT elé. Végül 2019. május 6-án született meg a Nemzetközi Büntetőbíróság legelső másodfokú ítélete e tárgyban, mely Jordániát újfent elmarasztalta együttmúködési kötelezettségének elmulasztása miatt.

A fentebb nevesített államok közös jellemzői, hogy (i) valamennyi részes állama a Római Statútumnak; (ii) valamennyi államterületére hivatalos látogatást tett al-Bashír az elmúlt években, végül pedig, hogy (iii) egyikük sem hajtotta végre - a Római Statútum 98. cikk (1) bekezdésére hivatkozva - a bíróság által kiadott letartóztatási parancsokat, holott erre a 89. cikk (1) bekezdése alapján kötelesek lettek volna. A kérdés tehát továbbra is az, hogy milyen kapcsolatban áll egymással a 27. cikk és a 98. cikk (1) bekezdése, azaz hogy előbbi eltörli-e a felsorolt államok fennálló nemzetközi szokásjogi kötelezettségeit az államföi immunitás vonatkozásában? Jóllehet a tárgyalás-előkészítő tanácsok szép számban foglalkoztak a két cikk egymáshoz való viszonyával, a bíróságnak - jó ideig - nem sikerült egységes joggyakorlatot kialakítania: az elsőfokú határozatok érvelése több helyen gyenge lábakon áll, ám ami a bíróság külsô megítélése szempontjából ennél sokkal aggasztóbb, hogy az esetjog ebben a kérdésben is inkoherens.

2019 két szempontból is fordulatot hozott az ügyben. Az első, hogy a Jordánia-itélettel megszületett az első fellebbviteli döntés a kérdésben, amely több jogértelmezési vitának várva várt végét jelentette. A második pedig, hogy elmozdították al-Bashírt államfői hivatalából, amivel az immunitásprobléma egyelőre kihunyt. Ellenben a két rendelkezés egymáshoz való viszonyának megítélése miatt a kamarák álláspontjai és az azok között meghúzódó ellentétek továbbra is szemléletesek a jövőbeli jogértelmezési kérdések tisztán látása okán.

568 Decision on the non-compliance by the Republic of Djibouti with the request to arrest and surrender Omar Al Bashir to the Court and referring the matter to the United Nations Security Council and the Assembly of the State Parties to the Rome Statute, The Prosecutor v. Omar Hassan Ahmad Al Bashir, ICC-02/05-01/09-266, ICC Pre-Trial Chamber II, 11 July 2016 (a továbbiakban a hivatkozásokban: II. Dzsibuti-határozat).

569 Decision on the non-compliance by the Republic of Uganda with the request to arrest and surrender Omar Al Bashir to the Court and referring the matter to the United Nations Security Council and the Assembly of State Parties to the Rome Statute, The Prosecutor v. Omar Hassan Ahmad Al Bashir, ICC-02/05-01/09-267, ICC PreTrial Chamber II, 11 July 2016 (a továbbiakban a hivatkozásokban: Uganda-határozat).

570 Decision under article 87(7) of the Rome Statute on the non-compliance by South Africa with the request by the Court for the arrest and surrender of Omar Al-Bashir, The Prosecutor v. Omar Hassan Ahmad Al Bashir, ICC-02/05-01/09-302, ICC Pre-Trial Chamber II, 6 July 2017 (a hivatkozásokban a továbbiakban: Dél-Afrika-határozat). 
8.3.1. A „vertikális hatály" vizsgálata: az együttmüködési kötelezettség és az immunitás összeütközése esetén alkalmazható megközelitési módok

A fenti tényállásból adódó kérdések megválaszolása előtt kardinális jelentőségűnek mutatkozik annak tisztázása, hogy még ha maga az ICC a vádlott immunitását figyelmen kívül is hagyhatja, ugyanennek a terheltnek a mentessége az ICC által kiadott letartóztatási parancsot végrehajtó államoknak már komoly fejtörést okozhat. ${ }^{571}$

Tehát ha a bíróság megkeresést intéz egy államhoz egy nem részes állam terheltjének letartóztatása és átadása miatt, akkor először is azt kell tisztáznia, hogy az ICC valóban képes jogszerủen joghatóságot gyakorolni a konkrét terhelt ügyében („vertikális hatály”). Ha a válasz igen, akkor másodszor annak vizsgálata következik, hogy a vádlott letartóztatására a statútum által kötelezett állam ilyen cselekménye jogszerűnek minősül-e, azaz nem ütközik a megkeresett állam egyéb fennálló nemzetközi jogi kötelezettségeibe („horizontális hatály"). Ha a válasz itt is igenlő, akkor harmadszor azt kell mérlegelni, hogy a megkeresett állam valóban hajlandó lenne-e letartóztatni a körözött személyt („politikai dimenzió”). Már e ponton fontosnak látszik előrebocsátani, hogy míg az első két „tisztán jogi” kérdésre „tisztán jogi” érvekkel alátámasztva pozitív válasz adható, addig a harmadik kérdés egyértelmúen nemleges választ indikál az érintett államok ellentétes politikai akaratából adódóan, ami a jogi érvek dacára - legyenek azok bármilyen meggyőzőek is - teljességgel megbénítja a felelősségre vonást.

A szakirodalomban az elmúlt évek során az első két kérdés megválaszolására több lehetséges megközelítés kristályosodott ki, melyek közül az egyik (i) a problémák megoldását az „új keletư” nemzetközi szokásjog immunitás-normáiban keresi; egy másik (ii) a BT 1593. (2005) határozatának szövegére és a főszerv hatásköreire, valamint az ENSZ Alapokmány VII. fejezetére való hivatkozást véli kulcsfontosságúnak; míg egy harmadik (iii) a kérdésre adható korrekt választ egyszerúen abban látja, hogy az ICC bírái kötelesek a Római Statútum - így a 27. cikk - alkalmazására; (iv) végezetül az ICC fellebbviteli tanácsa a Jordánia-itéletben arra utalt, hogy bár Szudán nem részes állam, a Római Statútumot - és annak 27. cikkét - rá nézve is ugyanúgy alkalmazni kell, mint a szerződésben részes felekre. A soron következő részek ezeket a perspektívákat veszik sorra.

571 Jacobs, 2015, 286. o. 
8.3.2. A „vertikális hatály" vizsgálata a Malawi-határozat tükrében: az immunitás-kérdés megközelítése a nemzetközi szokásjog szemszögéből

Az első lehetséges igazolási módszer ismertetésekor azt kell tüzetesen megvizsgálni, hogy létezik-e a kortárs univerzális szokásjogban olyan norma, amely a nemzetközi törvényszékek előtti immunitás védőpajzsát áttöri. A nézet képviselőinek sommás következtetése szerint e norma fennállása lehetôvé teszi az ICC számára a jogszerú joghatóság-gyakorlást a nem részes államok hivatalos minőségú állampolgárai felett - még ha utóbbiakat a pacta tertiis nec nocent nec prosunt elve alapján a Római Statútum nem is köti, a szokásjogi norma ellenben igen, melyet a 27. cikk (1) bekezdése - mintegy tiszta kodifikációs normaként - ez esetben csupán írásba foglal..$^{572}$

A tárgyalás-előkészítő tanács ezt a megközelítési módot alkalmazta 2011-ben a Malawi-határozatban. A tanács úgy látta, hogy a kérdés eldöntéséhez meg kell vizsgálni, hogy létezik-e az általános nemzetközi jogban olyan szabály, amely mind a korábbi, mind az aktuálisan hivatalban lévő államfőket immunitásban részesíti a nemzetközi bíróságok előtt. ${ }^{573}$ Ennek érdekében a nemzetközi büntetőbíráskodás történetéből több példát felidézett, időben egészen a második világháborúig visszamenően, amikor is a nürnbergi elvek között kifejtésre került, hogy egy természetes személy hivatalos pozíciója e személyt büntetőjogi felelősségétől nem fosztja meg, illetve a büntetőeljárás megindításával szemben immunitásban nem részesíti. ${ }^{574} \mathrm{~A}$ határozatban foglalt történeti példák ${ }^{575}$ felsorakoztatásának egyetlen „szépséghibája”, hogy a tárgyalás-előkészítő tanács összevon két külön kezelendő kérdést: azt, hogy megakadályozhatja-e a hivatalos minőség egy természetes személy büntetőjogi felelősségét, illetve hogy gátat szabhat-e az immunitás az ICC tényleges joghatóság-gyakorlásának.

Ahogyan az már korábban említésre került, a Római Statútum 27. cikke e két fogalmat külön-külön szemléli: az (1) bekezdés az immunitás büntető anyagi jogi, a (2) bekezdés pedig az eljárásjogi oldalával foglalkozik. És míg elmondható, hogy napjainkra az (1) bekezdés szokásjogi tartalma a nürnbergi juriszdikció és a Nemzetközi Jogi Bizottság kodifikációs tevékenységének olvasztótégelyében egyértelmúen elfogadottá vált, a fentebb feltárt kérdés tisztázása terén utóbbi nem segít, az eljárásjogi immunitás fennállása tekintetében nem ad iránymutatást. Ebből adódik, hogy jelen vita eldöntésében a tárgyalás-előkészítô tanács által a Malawi-határozatban felhozott érvek ${ }^{576}$ (a nürnbergi és a tokiói Nemzetközi Katonai

572 Gaeta, 2009, 315. o.

573 Malawi-határozat 22. \$.

574 Malawi-határozat 23. \$.

575 Malawi-határozat 22-36. \$\$.

576 Malawi-határozat 24-27., 30., 31. \$\$. 
Törvényszékek Chartái, az ICTY Statútuma, az ICTR Statútuma) túlnyomóan irrelevánsnak bizonyulnak, mivel elsődlegesen anyagi jogi perspektívából közelítik meg az államfői immunitást. ${ }^{577}$

A Malawi-határozatban felhozott egyetlen érdemi példa a Yérodia-ügy megemlítése volt, melyben a Nemzetközi Bíróság akként érvelt - amellett, hogy megerősítésre került a nemzeti bíróságok előtti személyes immunitás fennállása -, hogy „egy hivatalban lévő vagy korábbi külügyminiszter egyes nemzetközi biróságok elött a büntetoóljárás terheltje lehet, amennyiben e biróságok joghatósággal rendelkeznek. Idesorolandó a volt Jugoszláviával foglalkozó Nemzetközi Büntető Törvényszék, illetve a Ruandával foglalkozó Nemzetközi Büntető Törvényszék - amelyeket a Biztonsági Tanács határozatai hoztak létre az Egyesült Nemzetek Alapokmányának VII. fejezete értelmében -, illetve idesorolandó az 1998. évi Római Statútummal megalakuló, jövőbeli Nemzetközi Büntetóbíróság. Utóbbi Statútuma kifejezetten rögzíti a 27. cikk (2) bekezdésében, hogy »a nemzeti vagy a nemzetközi szabályok szerint a hivatalos minőséggel járó mentességek vagy különleges eljárási szabályok nem akadályozzák a Bíróságot az adott személy fölött joghatóságának gyakorlásában«."ᄁ78

Paola Gaeta és William Schabas a fenti bekezdést a nemzetközi törvényszékek előtti immunitásra való hivatkozás elvetésének normatív értékeléseként illeti, ${ }^{579}$ míg Dapo $A k a n d e^{580}$ már óvatosabban fogalmaz, mivel úgy véli, ez a megközelítés a kérdés leegyszerűsítéséhez vezet. Akande emlékeztet rá, hogy a Yérodia-ügyben hozott ítélet fenti része obiter dictum, azaz a kérdésnek az ICJ elôtt lévő ügy érdemi elbírálásában szerves része nem volt, csupán a bírák fejezték ki arról alkotott véleményüket, hogy a nemzetközi bûncselekmények elkövetőinek büntetlenségéhez az eljárásjogi immunitás elismerésével nem járulnak hozzá. ${ }^{581}$ Másodszor - Dov Jacobs szerint -, az ICJ az általa nevesített különböző nemzetközi büntetôbírói fórumok között létrehozásuk módja szerint disztingvál. Ha a nemzetközi törvényszéket a Biztonsági Tanács határozata hozta létre az ENSZ Alapokmány VII. fejezete alapján, akkor észszerúen következtethetünk arra, hogy a törvényszékek statútumaiban olvasható immunitás eltörlésére vonatkozó rendelkezések az ICTY és az ICTR vonatkozásában az egész nemzetközi közösségre nézve kötelezőek. Ellenben, ha a törvényszéket egy szerződés hozta létre - csakúgy, mint a SCSL-t vagy az ICC-t -, akkor pusztán feltételezhetjük, hogy mivel nemzetközi búncselekményekkel állunk szemben, így a pacta tertiis nec nocent nec prosunt alóli kivétel jöhet létre, és emiatt a szerződésben nem részes államok az immunitásra sikeresen nem hivatkozhatnak. Jacobs szerint sokkal észszerübb értelmezésnek tủnik, hogy a bírói fórum nem

577 Jacobs, 2011 [Online].

578 Yérodia-ügy 61. \$.

579 Gaeta, 2009, 322. o. Schabas, 2008, 513. o.

580 Akande, 2004, 418. o.

581 Yérodia-ügy 60. \$. 
az aktuális nemzetközi jog tartalmának normatív értékelését vezette le, hanem a bírák csupán tényszerủ példákat vázoltak fel arra nézve, amikor nemzetközi bíróságok az immunitást mint a joghatóság gyakorlásának akadályát eltávolították. Továbbá úgy véli, a megfogalmazás finomsága ${ }^{582}$ is arra enged következtetni, hogy nem a nemzetközi bíróságok előtt általánosságban alkalmazandó, szokásjogból levezetett normatív tétel felvázolásáról van szó. Harmadsorban azt is megjegyzi, hogy a Nemzetközi Bíróságnak definiálnia kellett volna a "nemzetközi bíróság” fogalmát, melyek előtt általánosságban az immunitásra nem lehet hivatkozni. Jacobs illusztrációképpen azt az egyszerú példát hozza fel, hogy ha két állam - amelyek bíróságai előtt egyebként nyilvánvalóan jogszerúen lehet hivatkozni az államfői immunitás fennállására - aláír egy közös „nemzetközi büntetőbíróságot” létrehozó bilaterális szerződést, ezzel az aktussal önmagában véve az államfói immunitást nem törölhetik el. ${ }^{583} \mathrm{~A}$ példa sarkított jellegének ellenére a fent idézett szerzővel egyet lehet érteni abban, hogy az immunitás falának ledöntéséhez, az új szokásjogi norma kialakulásához ennél valóban többre van szükség.

A Malawi-határozat a kérdést tovább vizsgálva az SCSL fellebbviteli tanácsára is hivatkozik, mely a Taylor-ügyben szintén megkísérelte e probléma megoldását. Érvelése szerint „észre kell venni, hogy a Biztonsági Tanács a nemzetközi béke és biztonság fenntartásáért való felelősségéből fakadó kötelezettségének végrehajtása során az Egyesült Nemzetek tagjainak nevében jár el. Így az Egyesült Nemzetek és Sierra Leone között létrejött megállapodás egy, az Egyesült Nemzetek valamennyi tagja és Sierra Leone között létrejött megállapodás. Ebböl adódóan a megállapodás az egész nemzetközi közösség akaratát juttatja kifejezésre. Az ilyen feltételekkel létrehozott Különleges Bíróság pedig valódi nemzetközi jelleggel birr. ${ }^{n 84}$ Mindazonáltal Schabas úgy vélekedik, hogy a SCSL jogi érvelése nem áll szilárd lábakon. Meglátása szerint a Biztonsági Tanács részvételének ilyen irányú megközelítése nem egyeztethető össze a nemzetközi szervezetek jogával és annak elismerésével, hogy az ilyen szervezetek - különösképpen az ENSZ - a tagokétól elkülönülő, önálló jogalanyisággal rendelkezik. ${ }^{585}$ Összességében véve, ha a bizonytalan jogi okfejtés dacára a nemzetközi szokásjog tartalmára vonatkozó érvet el is fogadnánk, az azt jelentené, hogy tekintet nélkül arra, hogy az ügy miként került az ICC elé, ${ }^{586}$ a bíróság jogosult lenne a nem részes államok állampolgárai feletti joghatóságot gyakorolni.

582 Yérodia-ügy 61. \$: „egyes nemzetközi bíróságok előtt [...] amennyiben e bíróságokjoghatósággal rendelkeznek”.

583 Jacobs, 2015, 288. o.

584 Taylor-ügy 38-39. \$\$.

585 Schabas, 2016 [Online].

586 Gondoljunk például a Római Statútum 11. cikk (3) bekezdésére, amikor egy nem részes állam ad hoc jelleggel a bíróság joghatóságát magára nézve kötelezőnek ismeri el, vagy például a 12. cikk (2) bekezdés (a) pontjára, amikor egy részes állam területén egy nem részes állam állampolgársága szerinti elkövető követi el a bûntettet. 
Az ICC joggyakorlata ugyanakkor az utóbbi években a Malawi-határozatban kifejtetteknek hátat fordított. Al-Bashír Kongói Demokratikus Köztársaságban tett látogatása után a fogadó államot elmarasztaló döntésében egy másik tárgyalás-előkészítő tanács a Malawi-határozatban foglaltak ellen úgy érvelt, hogy „figyelembe véve, hogy a Statútum egy multilaterális nemzetközi szerződés, amelyre a szerzôdések jogáról szóló bécsi egyezmény szabályai vonatkoznak, a Statútum harmadik Államokra nézve - beleegyezésük nélkül-kötelezettségeket nem hozhat létre. Ezért a Statútum 27. cikk (2) bekezdésében meghatározott rendelkezések elviekben csak azokra az államokra vonatkoznak, amelyek ehhez hozzájárultak."587 Mindazonáltal a két döntés közötti kirívó inkoherencia mellett a Malawi-határozat önmagában véve is elhibázottnak tûnik azért, mert az anyagi jogi és az eljárásjogi vetületeket egyszerủen összemosta.

\subsubsection{A „vertikális hatály" vizsgálata a Kongói Demokratikus Köztársaságot elmarasztaló határozat tükrében: \\ a kérdés megközelitése a Biztonsági Tanács határozata szemszögéből}

Az ICC második megközelítése szerint egy, a Római Statútumban nem részes állam állampolgárságát viselő hivatalos minőségủ terhelt immunitásának eltörlése a Biztonsági Tanács határozatából adódik. Amikor a tárgyalás-előkészítő tanács 2014-ben elmarasztalta al-Bashír le nem tartóztatása miatt a Kongói Demokratikus Köztársaságot, ${ }^{588}$ felhagyott a Malawi-határozatban leírt állásponttal, és új vizekre evezett: kimondta, hogy a Római Statútum 27. cikk (2) bekezdését a nem részes államokra nem lehet alkalmazni a szokásjogban keresett igazolás alapján,, ${ }^{589}$ és - Schabast idézve - „egy sokkal árnyaltabb és finomabb prepozíciót" fogadott el. ${ }^{590}$ Ugyanakkor a tárgyalás-előkészítő tanács azt már nem indokolta pontosan, hogy miért fordított hátat az ügyben korábban eljáró tárgyalás-előkészítő tanács érvelésének, aminek elmulasztása miatt a bíróság nem kevés és nem ok nélkül megfogalmazott kritikai észrevételt vívott ki magának. ${ }^{591}$

Az eljáró tanács e határozatában a Biztonsági Tanács 1593. (2005) határozatára összpontosított, e perspektívából igyekezve az államfői immunitás elvetésére igazolást találni. A DRC-határozatban a bírák érvelésüket a 98. cikk (1) bekezdésére építették fel - vá-

587 DRC-határozat 26. \$.

588 E döntés érvelése sem bizonyult sikeresebbnek a Malawi- és Csád-határozatok érdemi részénél. A határozat egyetlen része, amelyet egyáltalán nem ért semmiféle kritika, az ICC szerepére vonatkozik, vagyis hogy e bíróság az egyetlen kompetens szerv az immunitás fennállásáról való döntéshozatalban. Lásd: Boschiero, 2015, 631-632. o.

589 DRC-határozat 26. \$.

590 Schabas, 2011 [Online].

591 Gaeta, 2011 [Online]. 
lasztásuk indokolásának újbóli elmulasztása mellett -, és abból indultak ki, hogy „mivel az al-Bashírhoz kapcsolódó immunitás a Bíróság elötti büntetőeljárás eljárási akadályát képezné, a Biztonsági Tanács határozatában elóirányzott együttmüködési kötelezettséget úgy kell értelmezni, amely a Bíróság elótti eljárás valamennyi gátját eltávolítja, beleértve az immunitás megszüntetését is”, majd a tanács ezután arra a következtetésre jut, hogy „a Biztonsági Tanács Omar al-Bashír államfói tisztségéhez a nemzetközi közjog normái alapján füzött immunitást hallgatólagosan eltörölte". ${ }^{592}$ Tehát a tárgyalás-előkészítő tanács úgy látta, hogy az immunitásról való lemondásra a 98. cikk (1) bekezdése alapján Szudán részéről nincs szükség, hiszen a Biztonsági Tanács 1593. (2005) határozata a fennálló eljárásjogi akadályt már „implicite” eltörölte. ${ }^{593}$ Noha maga a végkövetkeztetés észszerúnek és hatékonysági szempontból tetszetősnek tûnhet, a 98. cikk (1) bekezdésére történő ugrás némileg zavaros - mivel a korábban eljáró tárgyalás-előkészítő tanács gondolatmenetét a 27. cikk (2) bekezdése köré építette -, és a DRC-határozat érvelése sem nevezhető maradéktalanul koherensnek.

Az olvasóban rögtön felmerülhet az a kérdés, hogy vajon a Biztonsági Tanács egyáltalán jogosult-e arra, hogy egy nemzetközi szokásjogban megszilárdult normától hallgatólagosan eltérjen? Mint ahogyan arra Manuel Ventura is felhívja a figyelmet: ha a Biztonsági Tanács egy szokásjogi normától el akar térni, akkor annak kifejezettnek kell lennie, azaz a hallgatólagos eltérés nem megengedett. ${ }^{594}$ Ugyanakkor a helyes megközelítés a bíróság előtt lévő ügy szempontjából aligha életképes: a Biztonsági Tanács 2005-ben nem láthatta előre, hogy a Főügyészi Hivatal 2009-ben vádat fog emelni a szudáni államfővel szemben, és az is jogellenes gyakorlat lett volna a részéről, ha erre bármiféle utalást tesz. Itt is hangsúlyozni kell, hogy a BT politikai szerv, és a vádemelés tekintetében hatáskörrel nem rendelkezik.

\subsubsection{A „vertikális hatály" vizsgálata:}

a kérdés megközelitése a Római Statútum 27. cikk (2) bekezdése felól

A kérdés megközelítésének utolsó és egyben legegyszerủbb módja, ha fontolóra vesszük, hogy a 27. cikk (2) bekezdése a részes és nem részes államok állampolgárai között nem disztingvál, és abból indulunk ki, hogy a 21. cikk ${ }^{595}$ értelmében az ICC bírái

592 DRC-határozat 29. \$.

593 Boschiero, 2015, 640. o.

594 Ventura, 2015, 996. o.

595 Római Statútum 21. cikk: „(1) A Bíróság a következóket alkalmazza:

a) Elsősorban a jelen Statútumot, a Büncselekmények Tényállási Elemeit, továbbá az Eljárási és Bizonyitási Szabályokat;

b) Másodsorban, adott esetben, az ügyben alkalmazandó egyezményeket és a nemzetközi jog alapelveit és szabályait, ideértve a nemzetközi jognak a fegyveres konfliktusokra vonatkozó, általánosan elismert alapelveit; 
első helyen a Római Statútumot kötelesek alkalmazni, akkor abból az is következik, hogy a bírák ipso iure kötelesek a 27. cikk (2) bekezdésének alkalmazására, azaz a bíróság előtti eljárás valamennyi akadályának, így az immunitásnak a figyelmen kívül hagyására. Ez a módszer az ICC jelenlegi gyakorlatával összecseng: az al-Bashír ellen kiadott első letartóztatási parancsban olvasható, hogy a Római Statútum 21. cikke értelmében a nemzetközi jog egyéb jogforrásaira történő hivatkozás nem szükséges a 27. cikk tartalmának meghatározása és alkalmazása érdekében, mert annak tartalma egyértelmú és köti a bírákat. ${ }^{596}$

Azonban e megközelítés sem nélkülözi a szakirodalomban a kritikát: Paola Gaeta akként érvel, hogy ezen érvelés figyelmen kívül hagyja a 27. cikk szerződéses természetét, amely a szerző szerint mélyebb nemzetközi szokásjogi analízis nélkül a nem részes államokra nem terjeszthető ki. Dov Jacobs vitába száll Gaetával, mivel szerinte a fenti kritika nem veszi figyelembe sem a 27. cikk tényleges kifejezésmódját, sem az ICC bíráinak funkcióját. Jacobs meglátása szerint a 27. cikket technikai értelemben nem az államoknak címezték: a paragrafus egy lehetséges eljárásjogi akadály figyelmen kívül hagyásáról rendelkezik - melynek valódi címzettjei a bírák -, így helytelen megközelítésre vall, ha azt vizsgáljuk, hogy e cikk Szudánra nézve kötelező erővel bír-e, merthogy valójában nem ez a kérdés, és e felfogás a bírák szerepének félreértéséhez vezethet. A nemzeti bírákhoz hasonlóan - akiket kötnek az adott állam jogszabályai - az ICC-t a Római Statútumban foglaltak kötik, és az eljáró tanácsok nem rendelkeznek diszkrecionális jogkörrel a jogszabályi keretektől való eltérésre. Úgy véli, hogy az már más lapra tartozna, ha esetlegesen az ICC nemzetközi jogi értelemben jogellenesen járna el Szudánnal - mint egy, a Római Statútumban nem részes állammal szemben -, mint ahogyan a belső jog alkalmazása is vezethet nemzetközi jogsértéshez, merthogy az ICC bírái is kerülhetnének hasonló helyzetbe a statútum alkalmazása során. Ebben az esetben azonban értelemszerúen nem maga a bíró, hanem a bíróság mint a nemzetközi jog önálló alanya felelne az esetlegesen beálló jogsérelemért. ${ }^{597}$

c) Ha az elóbbiek nem lehetségesek, a Bíróság által a világ jogrendszereinek nemzeti szabályaiból levezetett általános jogelveket, ideértve, adott esetben, azoknak az Államoknak a nemzeti jogát, amelyek egyébként általában joghatósággal rendelkeznének a büncselekmény tekintetében, ha ezek a jogelvek nem ellentétesek a jelen Statútummal, a nemzetközi joggal, továbbá a nemzetközileg elismert normákkal és követelményekkel.

(2) A jogi alapelveketés más szabályokat a Bíróság úgy alkalmazhatja, ahogyan azokat korábbi döntéseiben értelmezte.

(3) A jog jelen cikknek megfelelő alkalmazásának és értelmezésének összhangban kell állnia a nemzetközileg elismert emberi jogokkal, és nem lehet hátrányosan megkülönböztető a nemek 7. cikk 3. bekezdésében meghatározott szempontja, életkor, faj, börszín, nyelv, vallás vagy vallásos meggyőződés, politikai vagy egyéb vélemény, nemzeti, etnikai vagy társadalmi származás, vagyon, születés vagy egyéb helyzet szerint."

596 Második letartóztatási parancs al-Bashír ellen 44. \$.

597 Jacobs, 2015, 292. o. 
Sommásan tehát azt mondhatjuk, hogy e megközelítés elsajátításának következménye az lenne, hogy az ICC joghatóságot gyakorolhat a nem részes államok állampolgárai felett, tekintet nélkül arra, hogy a helyzet a Biztonsági Tanács által, egy részes állam kezdeményezésével, vagy a föügyész proprio motu utalásával került a bíróság elé.

\subsubsection{A "horizontális hatály" vizsgálata:}

az együttmüködési kötelezettség az egyes részes államok oldalán

Ha az imént felsorakoztatott érvek alapján elfogadnánk, hogy az ICC jogszerúen járhat el a nem részes államok hivatalos minőségú állampolgárai felett, akkor a soron következő kérdés az, hogy ilyen esetekben fennáll-e az egyes államok letartóztatási és átadási kötelezettsége?

E ponton ugyanis rá kell mutatni még egy apró metodológiai gócpontra. Ha elfogadjuk, hogy a Római Statútum 27. cikke a nem részes államokra is vonatkozik, akkor abból hajlamosak lehetünk azt a következtetést levonni, hogy a 27. cikk minden, a 98. cikk (2) bekezdése alapján felmerülő immunitásszerủ eljárási akadályt eltávolít. Erre a legjobb példa a DRC-határozatban olvasható, amikor a tárgyalás-előkészítő tanács a 27. cikk (2) bekezdéséből kiindulva arra a következtetésre jutott, hogy horizontális szinten a Kongói Demokratikus Köztársaság és Szudán között sincsen semmi akadálya a letartóztatási parancsok végrehajtásának. ${ }^{598}$

Ugyanakkor ez a következtetés - ahogyan arra már fentebb is történt utalás - korántsem magától értetôdő. Ha át is vesszük az eljáró tanácsok fentebb felsorakoztatott álláspontját - miszerint az immunitás a bíróság előtti büntetőeljárást nem akadályozza -, ez csakis vertikálisan, azaz az ICC és a harmadik állam koordináta-rendszerében alkalmazható. Azonban a 98. cikk (2) bekezdésének tárgyi hatálya másra vonatkozik: a Római Statútumban részes és nem részes államok viszonyára, tehát ez esetben egy horizontálisan érvényesülő normáról van szó. Ha a kérdést így szemléljük, akkor arra juthatunk, hogy míg az ICC joghatóságot gyakorolhat olyan államok állampolgárai felett, akik egyébként a szokásjognak köszönhetően az immunitásból eredő előnyöket élvezhetnék, utóbbi nem jelenti azt, hogy a 98. cikk (1) bekezdése ennek a személynek a letartóztatását és átadását nem akadályozhatná meg - ha pedig nem akadályozhatná meg, akkor vélhetôen egyáltalán nem lett volna értelme a 98. cikk (1) bekezdés statútumba foglalásának. ${ }^{599}$

Azért nem sajátítható el egyszerúen az az álláspont, hogy a 27. cikk alkalmazása a 98. cikk (1) bekezdése alapján hivatkozható immunitás valamennyi fajtáját automatikusan és logikai 
szükségszerúséggel eltávolítja, mert utóbbi jogszerủ alkalmazhatósága további igazolásokat követel a vizsgálódótól. Ebben a körben is a fentebb ismertetett három szempontot kell sorra venni: (i) a szokásjogot; (ii) a Biztonsági Tanácsot; valamint (iii) a statútum alkalmazásának kötelezettségét a bírák számára.

Ami a nemzetközi szokásjogot illeti, meg kell nézni, hogy létezik-e olyan norma, amely megszünteti az immunitást a nemzetközi büntetőbírói fórumoknak történő átadás céljából foganatosított letartóztatás vonatkozásában. E gondolatmenet az, amelyet a kezdetben eljáró tárgyalás-előkészítő tanács is megkísérelt végigvinni - mondhatni inkább kevesebb, semmint több sikerrel - a Malawi-határozatban: „E Tanács figyelembe vette, hogy a nemzetközi közösség elkötelezettsége az immunitás elutasítása mellett - azon esetekben, amikor nemzetközi bíróságok nemzetközi büncselekmények elkövetésének alapos gyanúja miatt bocsátanak ki letartóztatási parancsot - elérte a kritikus tömeget. Ha valaha szükséges is volt hangsúlyozni, többé már nem kell, hogy jelen kontextusban a nemzetközi szokásjog immunitásra vonatkozó normái alkalmazandók.ºo Ezen érvelésből továbbra sem olvasható ki a 27. cikk vertikális és a 98. cikk (1) bekezdésének horizontális hatályának felismerése, és sem az állami gyakorlat, sem az opinio iuris komolyabb vizsgálata nem áll mögötte.

Sokkal „elegánsabb” és jobban védhető álláspont lett volna a tárgyalás-előkészítő tanács részéről, ha nem azzal érvel, hogy a 27. cikkben deklarált norma szokásjogi természetû és két állam horizontális viszonyában történő alkalmazhatóságát is szokásjogi természetû́ norma támasztja alá, hanem inkább azzal, hogy ha a 27. cikkben deklarált norma szokásjogi természetû, akkor két állam horizontális viszonyában a hatékonyság elve és a büntetlenség elleni harc imperatívusza indokolhatja e rendelkezés alkalmazhatóságát. A tárgyalás-elókészítő tanács a hatékonyság szemszögéből való megközelítésre 2013-ban a II. Csád-határozatban már sokkal nagyobb hangsúlyt fektetett, amikor is számításba vette, hogy az ICC a nemzeti bíróságoktól eltérően önálló végrehajtási mechanizmussal nem rendelkezik, így főképp az államok együttmúködésére kell hagyatkoznia, amely nélkül mandátumát képtelen betölteni. Mindazonáltal az államok részéről politikai okokból eredôen hiányzik az együttmúködési hajlandóság, és ha nem vezethetők le jogszerûen a Biztonsági Tanács határozatából a végrehajtáshoz szükséges jogkövetkezmények, akkor a határozat szövege kiüresedik, a Biztonsági Tanács utalási hatásköre pedig impotenssé válik. ${ }^{601}$

Továbbá fontolóra kell venni, hogy ha elfogadjuk a szokásjogra való hivatkozást, akkor e norma nemcsak a Római Statútum részes államaira, hanem valamennyi létező államra együttmüködési kötelezettséget ró - amennyiben a bíróság az együttmúködést kérelmezi -, 
így olyan esetekben is, amikor az immunitással kapcsolatban nem merül fel kérdés - tekintve, hogy az univerzális nemzetközi szokásjog minden államra nézve kötelező. Azonban erősen kétséges, hogy a Római Statútum „megalkotói” a szóban forgó rendelkezések lefektetésekor ilyen súlyos és jogilag megkérdőjelezhető jogkövetkezményeket tartottak volna szem előtt, hiszen ez aránytalanul elnagyoltan, ultra vires szembemenne a szerződések relatív hatályának elvével. ${ }^{602}$

Ami a Biztonsági Tanácshoz kapcsolódó érvet illeti, szintén azt kell körbejárni, hogy az ENSZ főszerve a horizontális immunitás mellett a vertikális immunitást is eltörölte-e. Utóbbi érvelés a DRC- és a II. Dzsibuti-határozatokban érhető tetten. ${ }^{603}$ Ezzel az érvvel kapcsolatban is ugyanazok a kérdések terjeszthetők elö, mint amik a „vertikális hatállyal”: eltörölhet-e a Biztonsági Tanács hallgatólagosan egy szokásjogi normát? A tárgyalás-elökészítő tanács arra vonatkozó érve, hogy ha bárhogy máshogy tekintünk az immunitásra, akkor a Biztonsági Tanács határozatában a Szudánra vonatkozó együttmúködési és segítségnyújtási kötelezettség teljes mértékben értelmét veszítené, ide is értendő. ${ }^{604} \mathrm{E}$ hipotézissel kapcsolatban Paola Gaeta arra világít rá, hogy érvelése nem minden esetben állja meg a helyét, minthogy például a kiadatásról szóló nemzetközi egyezmények sem válnak attól értelmetlenné, mert egy állam nem tud kiadni egy nemzetközi elfogatóparancsot egy államfó, kormányfő vagy külügyminiszter ellen. ${ }^{605}$

A második kérdés ezzel kapcsolatban, hogy kiterjed-e egyáltalán a hatásköre a Biztonsági Tanácsnak az immunitás kifejezett eltörlésére? Az ICC esete az ad hoc törvényszékek esetétől teljességgel különbözik, hiszen utóbbiakat a Biztonsági Tanács határozatai állították fel, így felállításuk teljes mértékben az ENSZ Alapokmány VII. fejezete alapján történt. Ellenben a Római Statútum egy multilaterális nemzetközi szerződés - az ICC pedig egy, az ENSZ-től független, önálló nemzetközi jogalanyisággal bíró fórum -, amely nem az ENSZ Alapokmány VII. fejezetének égisze alatt jött létre. ${ }^{606} \mathrm{E}$ felvetés kihangsúlyozása ugyanakkor teljesen feleslegesnek tűnik abból a szempontból, hogy az ENSZ Alapokmányának 39. cikkéből levezethető, hogy a Biztonsági Tanács a nemzetközi béke helyreállítása érdekében jogosult az általa szükségesnek tartott rendszabályok foganatosítására, így jogosult a szokásjogi normák felülírására is.

Továbbá a tárgyalás-elôkészítő tanácsot a DRC-határozat miatt azért érték még kritikák, mert többen úgy vélték, hogy az eljáró kamara félreérti a jogi helyzetet, amikor Szudán együttmúkködési kötelezettségét vizsgálja, mivel utóbbi esete nem tartozik a 98. cikk (2) be-

602 Jacobs, 2015, 294. o.

603 DRC-határozat 29. \$.; II. Dzsibuti-határozat 11. \$.

604 DRC-határozat 29. \$.

605 Gaeta, 2014 [Online].

606 Jacobs, 2015, 295. o. 
kezdés hatálya alá, tekintve, hogy a Biztonsági Tanács határozata csupán „felhívja”, semmint kötelezi az államokat, hogy múködjenek együtt a bírósággal. Mindazonáltal e kritika nem lát a bírák érvelése mögé: ami mellett a tárgyalás-előkészítő tanács érvelni próbál - még ha azt kissé sután is teszi -, az az, hogy mivel Szudánnak egyértelmúen fennáll az együttmúködési kötelezettsége, így e kötelezettséget a statútummal összhangban kell értelmezni. Így a 98. cikk (1) bekezdés alapján valóban nem lehetne hivatkozni semmiféle együttmúködési kötelezettségre sem, mert a harmadik állam olyan jogállásba kerülne, mintha a Római Statútumnak részes állama lenne.

\subsubsection{A politikai dimenzió vizsgálata: az Afrikai Unió}

A Nemzetközi Büntetóbíróságról szóló tudományos diskurzusokban gyakran kerül szóba a bíróság és az Afrikai Unió problémás kapcsolata, ${ }^{607}$ melynek egyik gócpontja alBashír ügyéből bontokozott ki: az eset olyan intenzív regionális politikai feszültséget generált az utóbbi években, hogy több afrikai állam is bejelentette, jobbnak látja, ha felmondja a Római Statútumot. ${ }^{608}$ És bár a tényleges kilépésig mostanáig csupán Burundi jutott el, nem lehet figyelmen kívül hagyni azt a tónust, ahogyan az Afrikai Unió megszólítja tagállamait, ha az ICC-ről van szó: a volt szudáni elnök külföldi látogatásai alkalmával a regionális nemzetközi szervezet több alkalommal szólította fel tagállamait bírósággal történő együttmûködés megtagadására.

E viszony elmérgesedésének fô okát az Afrikai Unió azon vádpontjával lehetne sommásan összefoglalni, hogy az ICC egy neoimperialista intézmény, amely a kontinenst jogtalanul veszi célba. Már a nürnbergi Nemzetközi Katonai Törvényszék felállítása óta időről időre felsejlik a nemzetközi büntető igazságszolgáltatással kapcsolatban az a meglátás, hogy az valójában nem más, mint a győztesek megtorló eszköze a legyőzöttek felett (victors' justice). Ahogyan arról William Schabas is ír, a nemzetközi büntető igazságszolgáltatás „a konfliktusban győztes félnek lehetöséget biztosit arra, hogy démoni szinekben tüntesse fel az ellenfelet, tisztára mossa a maga büneit, és életben tartsa az igazságtalanságot" ${ }^{609} \mathrm{E}$ klasszikus kettős mérce az AU szerint az ICC esetében abban ölt testet, hogy a bíróság gyakorlatában állandósultak az afrikai helyzetekkel kapcsolatos ügyek, ellenben ha a Római Statútum normái valamelyik másik földrészen szenvednek sérelmet, afelett a bírói fórum nagyvonalúan átsiklik. ${ }^{610}$ Noha e kritikák megfogalmazódásakor még valóban igaz volt, hogy csak

607 Béres, 2019, 5-18. o.

608 Arnould, 2017 [Online].

609 Schabas, 2017, 6. o.

610 Du Plessis, 2009, 442-443. o. 
afrikai helyzetekkel foglalkozott a nemzetközi büntetőbírói fórum, jelen sorok írásakor a déloszét, ${ }^{611}$ a palesztin, ${ }^{612}$ a bangladesi-mianmari ${ }^{613}$ és az afganisztáni ${ }^{614}$ konfliktusokkal ez a hegemónia már megtört, valamint egyéb, nem afrikai helyzetek vonatkozásában is sor került előzetes vizsgálatokra. ${ }^{615}$

Másfelól az az egyszerú statisztikai tény is beszédes, hogy bár jelenleg tíz afrikai helyzet van az ICC előtt, ebből öt esetben maga a konfliktus anyaállama folyamodott segítségért az ICC-hez: Uganda, ${ }^{616}$ a Kongói Demokratikus Köztársaság, ${ }^{617}$ a Közép-afrikai Köztársaság ${ }^{618}$ (két alkalommal) és Mali ${ }^{619}$ - így ezek az esetek aligha írhatók a bíróság elfogultságának számlájára. Kenya, ${ }^{620}$ Elefántcsontpart, ${ }^{621}$ Burundi, ${ }^{622}$ Grúzia, Banglades/ Mianmar és Afganisztán - esetén pedig az ICC Fő̈ugyészi Hivatala proprio motu kezdeményezett hivatalból előzetes vizsgálatot, majd nyomozást. Felmerülhet a kérdés, hogy vajon a bíróság fő̈ügészei saját hatáskörben történő eljárásindításukkal célkeresztbe állították-e Afrikát?

Erre a kérdésre egyértelmúen nemleges válasz adható a bíróság előtti eljárásindítás garanciáinak köszönhetően. Egyrészt maga a Főügyészi Hivatal eljáráskezdeményezése még véletlenül sem esetleges: szigorúan szabályozott folyamatról van szó, melyhez komplex követelményrendszer társul. Ezek megismerésének legjobb eszközei a Főügyészi Hivatal által előszeretettel - ám egyes nézetek ${ }^{623}$ szerint eltúlzott mennyiségben és gyakorisággal - kiadott ún. szakpolitikai dokumentumok, nevezetesen a már korábban is hivatkozott 2013. novemberi szakpolitikai dokumentum az előzetes vizsgálatokról, valamint 2016 szeptemberéből a bíróság előtti helyzetek kiválasztásáról és

611 A konfliktusról és az eljárás előrehaladásáról bővebben lásd az ICC honlapját: https://www.icc-cpi.int/ georgia [Letöltve: 2021. 04. 12.].

612 A konfliktusról és az eljárás előrehaladásáról bővebben lásd az ICC honlapját: https://www.icc-cpi.int/palestine [Letöltve: 2021. 04. 12.].

613 A konfliktusról és az eljárás előrehaladásáról bővebben lásd az ICC honlapját: https://www.icc-cpi.int/bangladesh-myanmar [Letöltve: 2021. 04. 12.].

614 A konfliktusról és az eljárás előrehaladásáról bővebben lásd az ICC honlapját: https://www.icc-cpi.int/afghanistan [Letöltve: 2021.04 . 12.].

615 Kolumbia, Nigéria, Gabon (lezárt), Guinea, Honduras (lezárt), Irak, Comore-szigetek (lezárt), Koreai Köztársaság (lezárt), Fülöp-szigetek, Ukrajna, Venezuela (lezárt), lásd: https://www.icc-cpi.int/pages/pe.aspx [Letöltve: 2020 . 01. 06.].

616 Lásd bővebben az ICC honlapján: https://www.icc-cpi.int/uganda [Letöltve: 2021. 04. 12.].

617 Lásd bővebben az ICC honlapján: https://www.icc-cpi.int/drc [Letöltve: 2021. 04. 12.].

618 Lásd bővebben az ICC honlapján: https://www.icc-cpi.int/car; https://www.icc-cpi.int/carII [Letöltve: 2021.

04. 12.].

619 Lásd bővebben az ICC honlapján: https://www.icc-cpi.int/mali [Letöltve: 2021. 04. 12.].

620 Lásd bővebben az ICC honlapján: https://www.icc-cpi.int/kenya [Letöltve: 2021.04.12.].

621 Lásd bővebben az ICC honlapján: https://www.icc-cpi.int/cdi [Letöltve: 2021. 04. 12.].

622 Lásd bővebben az ICC honlapján: https://www.icc-cpi.int/burundi [Letöltve: 2021. 04. 12.].

623 William A. Schabas nyitóbeszéde a Galwayben 2018. június 18-án, az Irish Centre for Human Rights által szervezett, International Criminal Court Summer School 2018: The ICC and Africa címú nyári egyetemen. 
az előnyben részesítés szempontjainak meghatározásáról szóló. E dokumentumok elvi kereteket szabnak a Fôügyészi Hivatal tevékenységének, és voltaképpen a múvelt nemzetek által elismert olyan általános jogelvek foglalatai, amelyek valamennyi modern demokratikus jogállam igazságszolgáltatási rendszerét áthatják: ilyen a függetlenség, a pártatlanság és az objektivitás, melyek zsinórmértékként szolgálnak a nemzetközi büntetőeljárások megindításánál. ${ }^{624} \mathrm{~A}$ szakpolitikai dokumentumok ún. jogi szempontokat is meghatároznak, mely általánosnak hangzó alcím alatt a joghatóság, az elfogadhatóság és az igazság érdeke kerül a mérleg serpenyőibe. ${ }^{625}$ Ezen túl az egyes ügyek kiválasztásakor az elkövetni vélt bưncselekmények tárgyi súlya és a gyanúsított vélt felelőssége nagy súllyal esik a latba, ${ }^{626}$ valamint nyilvánvalóan olyan elérendő jogpolitikai célok is befolyásoló tényezőként játszanak közre, mint az átláthatóság, a büntetlenség felszámolása és a prevenció. ${ }^{627}$

Másrészt a proprio motu eljárások ellensúlyát képezi az ICC tárgyalás-előkészítő tanácsainak voltaképpeni „nyomozási bíró” szerepe is, mivel az ilyen eljárások megindítása csakis a bírák felhatalmazásával történhet a Római Statútum 15. cikk (4) bekezdése ${ }^{628}$ alapján. (Emellett megjegyzésre érdemes, hogy a tárgyalás-előkészítő tanács pontos szerepéről, hatáskörének terjedelméről a Római Statútum - a föügyészről szóló - 15. cikke szerinti eljárásban még az ICC bírái között is megoszlanak a vélemények. Ez tisztán körvonalazódik Kovács Péter párhuzamos indokolásában, amelyet a déloszét helyzet kapcsán indított föügyészi nyomozás engedélyezésében hozott határozathoz fúzött. ${ }^{629}$ )

Az afrikai regionális nemzetközi szervezet kritikájának másik méregfoga a Biztonsági Tanács eljáráskezdeményezô jogosultsága, valamint ennek kapcsán a hivatalban lévő államfók elleni vádemelések kérdése. ${ }^{630} \mathrm{Nem}$ meglepő módon az AU első hivatalos „bíróságellenes” felszólalása ${ }^{631}$ közvetlenül az utánra tehetô, hogy az ICC Főügyészi Hivatala 2009-ben - miután 2005 márciusában a BT az ICC elé utalta a dárfúri konfliktust, és kiadta az első letartóztatási parancsot Omar al-Bashír ellen. Az ezt követő években

624 Policy Paper on Preliminary Examinations 7-8. \$\$.

625 Policy Paper on Case Selection and Prioritisation 9-12. \$\$.

626 Policy Paper on Case Selection and Prioritisation 12-15. \$\$.

627 Policy Paper on Preliminary Examinations 22-25. \$\$.

628 Római Statútum 15. cikk (4) bekezdés: „Ha a tárgyalás-elókészitő tanács a kérelem és az ahhoz csatolt bizonyító iratok megvizsgálása után azt állapitja meg, hogy a nyomozás meginditása indokolt, és az ügy a Bíróság joghatósága alá tartozónak látszik, engedélyezi a nyomozás megkezdését, anélkül, hogy ez késóbb befolyásolná a Bíróság arra vonatkozó döntését, hogy az ügy a joghatósága alá tartozik-e és elfogadható-e."

629 Decision on the Prosecutor's Request for Authorization of an Investigation. Separate Opinion of Judge Péter Kovács, Situation in Georgia, ICC Pre-Trial Chamber, Doc. ICC-01/15-12-Anx1, 27 January 2016.

630 Maunganidze és du Plessis, 2015, 66. o.

631 AU Assembly: „Decision on the Meeting of African States Parties to the Rome Statute of the ICC, Thirteen Ordinary Session" 3 July 2009, Doc. Assembly/AU/13(XIII), \$10. 
az AU ICC elleni megnyilvánulásai csak még tovább gyarapodtak, a helyzetet pedig tovább tetézte a kenyai Uhuru Muigai Kenyatta ${ }^{632}$ elleni vádemelés. És bár a Kenyatta elleni vádakat a bíróság Főügyészi Hivatala elégtelen bizonyítékokra hivatkozva 2014 decemberében ejtette, al-Bashír esetére mind a mai napig feszülten figyel a nemzetközi közösség.

Ahogyan arról már az előzőekben szó esett, az ügy homlokterében az államfői immunitás, valamint az ICC és az államok együttmúködésének kérdése áll. Utóbbi vonatkozásában - az AU álláspontja szerint - a Római Statútumban nem részes államokat még akkor sem lehetne együttmúködésre felszólítani, ha az adott konfliktusos helyzetet a BT utalta a bíróság elé. Ezen túlmenően az al-Bashír elleni első elfogatóparancs kibocsátása után kifejezetten azt javasolta valamennyi afrikai államnak, hogy tartózkodjon az ICC-vel való együttmúkködéstől a szudáni elnök ügyében. ${ }^{633}$ Tette ezt annak ellenére, hogy a nemzetközi visszhang - több jogvédő szervezet, például az Amnesty International és a Human Rights Watch - lelkesen üdvözölte az al-Bashír elleni elfogatóparancs kiadásának hírét. ${ }^{634}$ Az AU emellett felszólította a BT-t, hogy a Római Statútum 16. cikke értelmében 12 hónappal halassza el az ügyben a nyomozást. A fenti felhívás abba a nem szerencsés helyzetbe hozta a Római Statútum afrikai részes államait, ${ }^{635}$ hogy válasszanak fennálló nemzetközi jogi kötelezettségeik közül: ezek egyrészt az AU tagállamaiként a szervezethez kötik őket, másrészt a Római Statútum részes államaiként a bíróság felé tartoznak. ${ }^{636}$ Megjegyzendő, hogy mivel az AU Közgyúlésének határozatai csupán ajánlási értékúek, így valódi normakonfliktus a nemzetközi szervezet határozata és a Római Statútum - mint nemzetközi szerződés - között nem áll fent, mindazonáltal az e határozat által generált politikai feszültség vitathatatlanul intenzív.

Azóta, hogy az ICC tárgyalás-elókészítő tanácsa kibocsátotta az elnök elleni első elfogatóparancsot, al-Bashír számos afrikai államban tett hivatalos látogatást az AU csúcstalálkozóin, elsôként Kenyában. Kenya a Római Statútum részes állama - nemcsak

632 Decision on the Confirmation of Charges Pursuant to Article 61(7)(a) and (b) of the Rome Statute, The Prosecutor v. Uhuru Muigai Kenyatta, ICC Pre-Trial Chamber II, ICC-01/09-02/11-382-Red, 29 January 2012.

633 Decision on the Meeting of African States Parties to the Rome Statute of the ICC, Thirteen Ordinary Session, 3 July 2009, Doc. Assembly/AU/13(XIII), \$10.

634 Human Rights Watch: ICC: Bashir Warrant is Warning to Abusive Leaders, elérhető: https://www.hrw.org/ news/2010/02/03/icc-bashir-warrant-warning-abusive-leaders [Letöltve: 2020. 01. 09.]; Amnesty International: ICC Issues Arrest Warrant for Sudanese President Al Bashir, elérhető: https://www.amnesty.org/en/ latest/news/2009/03/icc-issues-arrest-warrant-sudanese-president-al-bashir-20090304/ [Letöltve: 2020. 01. 09.].

635 Az Afrikai Uniónak az 54 afrikai állam közül 53 tagállama, egyedül Marokkó nem csatlakozott a szervezethez, továbbá a Római Statútumban sem részes fél.

636 Tladi, 2009, 57. o. 
aláírta, hanem 2008-ban ki is hirdette ${ }^{637}$ a szóban forgó szerződést -, ennek ellenére elmulasztotta foganatosítani a szudáni elnök letartóztatását 2010 augusztusában. Kenya mulasztása az ICC első „együtt nem múködésről” szóló marasztaló döntéséhez vezetett, ${ }^{638}$ amelyet ugyebár sok másik hasonló határozat követett egyéb afrikai államokkal szemben. Bár ezek az államok részben az AU felszólításának eleget téve nem múködtek együtt a bírósággal a korábbi elnök letartóztatásában, nem lehet kategorikusan kijelenteni, hogy a Római Statútumban részes valamennyi afrikai állam negatív attitûdöt képvisel az ICC-vel szemben. E helyen említésre érdemesek Dél-Afrika kötelezettségszegésének közvetlen előzményei, ugyanis a pretoriai végrehajtó apparátus tétlenségének elsődleges oka túlmutat az AU-nak való megfelelés kérdésén, mivel az ENSZ és az AU közös dárfúri békefenntartó missziójában (United Nations - African Union Hybrid Operation in Darfur) szolgáló dél-afrikai egységeket blokád alá vették a szudáni kormányerők. ${ }^{639}$ Azonban sok afrikai állam továbbra is együttmúködik a bírósággal különböző kérdésekben, akár effektív jogsegélynyújtásról, akár az ICC eszmei támogatásáról van szó.

Végezetül idekívánkozik, hogy az AU Közgyưlése 2017 februárjában meghirdette az ún. kollektív kilépési stratégiáját a Római Statútum afrikai részes államai számára. Ennek hatására három állam, Burundi, a Dél-afrikai Köztársaság és Gambia jelezte is, hogy a Római Statútumot fel kívánják mondani. A tényleges kilépésig ugyan csak Burundi jutott el - mivel a dél-afrikai legfelső bíróság alkotmányellenesnek találta a felmondásra vonatkozó nyilatkozatot, Gambiában pedig kormányváltás következtében változott a hivatalos álláspont -, ugyanakkor magának a kilépés lehetőségének a felmerülése is komoly kritikával és kihívással szembesítette az ICC-t. ${ }^{640}$ További aggodalomra tarthat számot, hogy az ASP 2019. év decemberi ülésszakján a Dél-afrikai Köztársaság újfent hangot adott kilépési szándéka fontolgatásának. ${ }^{641}$

A regionális nemzetközi szervezet ${ }^{642}$ az al-Bashír-üggyel kapcsolatos dilemmák gyứrújében két „ICC-n kívüli megoldási javaslattal” állt elő, melyek közül az egyik, hogy az AU égisze alatt múködő bírói fórum, az Ember és Népek Jogainak Afrikai Bírósága ${ }^{433}$ tárgyi jog-

637 Kenya's International Crimes Act, Nairobi, 1 January 2009.

638 Decision requesting observations from the Republic of Kenya, The Prosecutor v. Omar Hassan Ahmad Al Bashir, ICC Pre-Trial Chamber I, ICC-02/05-01/09, 25 October 2010.

639 A nemzetközi közösséget azért is érte különös meglepetésként az a tény, hogy az AU védelmébe vette a szudáni államfôt, mert a regionális nemzetközi szervezet által indított dárfúri misszió (African Union Mission for Sudan, AMIS) kiváltképpen al-Bashír közbenjárásának köszönhetően fulladt kudarcba. Lásd bővebben: Besenyő, 2016.

640 Labuda, 2017 [Online].

641 Guilfoye, 2017 [Online].

$642 \mathrm{Az}$ afrikai emberi jogvédelmi mechanizmusról lásd bővebben: Marinkás, 2018, 136-169. o.

643 A bíróság múködéséről lásd bővebben: Kecskés, 2018, 190-195. o. 
hatóságát ki kellene terjeszteni egyes nemzetközi és transznacionális bủncselekményekre, ${ }^{644}$ míg a másik, hogy az Afrikai Unió - az ENSZ Közgyưlésén keresztül - tanácsadó véleményt kezdeményez a Nemzetközi Bíróságtól.

Ami az ACJHR büntető joghatósággal történő felruházását illeti, többéves tárgyalások után, 2014 júniusában fogadta el az AU Közgyúlése az Afrikai Bíróság statútumának módosításáról szóló ún. Malabo Jegyzőkönyvet, ${ }^{645}$ amelyet megnyitottak a ratifikálni szándékozó államok előtt. Az ACJHR joghatóságának kiszélesítése elsőre minden bizonnyal kecsegtető lépésnek mutatkozik a büntetlenség teljes felszámolása felé vezető rögös úton, azonban az ötlet valódi múködőképességét nyilvánvalóan csak a tényleges múködés tudná igazolni. Mindazonáltal a tervezet jelenlegi szövege tartalmaz néhány anomáliát - így például az alkotmányellenes kormányváltás jogintézményét -, ami valószínúsíthetően annak a „szakmaiatlan” elôzménynek a következménye, hogy a dokumentum szövegét sehol nem tették hozzáférhetővé az NGO-k és más külsős szakértők számára. ${ }^{646} \mathrm{~A}$ tervezetben foglaltaknak a joggyakorlatba való átültetéséhez hatékony segítséget nyújthatott volna a széles körú szakmai párbeszéd, különösen olyan összetett kérdések vonatkozásában, mint a joghatóság, a bưncselekmények tényállási elemei, az immunitás, a szervezeti struktúra, a végrehajtás, a belső jogra kifejtett hatások stb. ${ }^{647}$

Az AU Bizottsága akként foglalt állást e kérdésben, hogy a joghatóság kiterjesztésének gondolatát nem a nemzetközi szervezet „ICC-ellenessége” motiválta, hanem egyéb okok vezetettek a módosítások elôterjesztéséhez: (i) az AU szerint sok állam az univerzális joghatóság gyakorlásával visszaél; (ii) azok a kihívások, amelyeket Hissène Habré volt csádi elnök Szenegálban történt felelősségre vonása generált, valamint (iii) hogy az alkotmányellenes kormányváltást mint sui generis bưncselekményt szankcionálják. Még ha a fentiek igazságtartalmát nem is cáfoljuk, mégiscsak naivitás lenne azt feltételezni, hogy a tervezet megszületése nem hozható összefüggésbe az AU bíróságellenes attitúdjével - már csak a kiterjesztett joghatóságról való tárgyalások kezdetének időpontja is nagyon beszédes: közvetlenül azután indult meg a párbeszéd, hogy az ICC kiadta az első nemzetközi elfogatóparancsot al-Bashir ellen 2009-ben.

644 Draft Protocol on Amendments to the Protocol of the Statute of the African Court of Justice and Human Rights, Doc. Exp/Min/IV/Rev.7., Addis Abeba, 14-15 May 2012.

645 Protocol on Amendments to the Protocol on the Statute of the African Court of Justice and Human Rights, elérhető: https://au.int/en/treaties/protocol-amendments-protocol-statute-african-court-justice-and-humanrights [Letöltve: 2020.01 .31$.$] .$

646 Maunganidze és du Plessis, 2015, 79. o.

647 Du Plessis, 2012 [Online]. 
Az ACJHR büntető joghatóságának expanziójával kapcsolatban felmerül még egy kérdés: mégis mennyibe kerülne ez az AU-nak? Tudniillik a nemzetközi búncselekményekkel kapcsolatos eljárások lefolytatásához egyrészt szükség van megfelelő szakértelemmel és tapasztalattal bíró jogászokra, másrészt technikai eszközökre. Csak egy példa: az ICC költségvetése több mint tizennégyszerese az Afrikai Bíróság „büntető ügyszak" nélkül múködő struktúrája büdzséjének, és mintegy kétszerese az AU egész költségvetésének. ${ }^{648}$

Ami még a gyakorlatban esetlegesen felmerülő problémákat illeti, vajon hogyan alakulna ez esetben az ACJHR és az ICC kapcsolata? Hogyan viszonyulna egymáshoz e két bíróság joghatósága? E kérdés megválaszolása igencsak elsődlegesnek mutatkozik, tekintve, hogy az 54 afrikai államból 53 tagállama az AU-nak és 34 részes állama a Római Statútumnak, ennek ellenére a tervezet nem szabályozza a két bírói fórum kapcsolatát. Ebből következően lehetséges, hogy belső jogi aktusokra lenne szükség a módosítást ratifikáló, a Római Statútumban részes államok részéról a két bíróság közötti joghatósági kapcsolat tisztázásához.

Egyébiránt - kicsit eltekintve a bíróság joghatóságának esetleges kiterjesztésétől az ACJHR jelenlegi formájában is tartogat potenciált a nemzetközi büntető igazságszolgáltatás számára. A 2011-ben lezajlott arab tavasz derekán az ACJHR egyhangúan megszavazva kiadott egy határozatot, melyben ideiglenes intézkedéseket rendelt el, válaszul a Líbiában kibontakozó krízishelyzetre. ${ }^{649} \mathrm{~A}$ határozat felszólította Líbiát, hogy azon nyomban hagyjon fel minden olyan jogsértő cselekménnyel, amely az emberi élet kioltásával és a személyi integritás csorbításával járna. Az ACJHR e lépése merész volt és jól időzített: a bírói fórum felmérte az eset súlyát, és a konfliktusban részes felek álláspontjának meghallgatását nélkülözve az emberi életekre veszélyt jelentő azonnali kockázatra figyelemmel járt el. ${ }^{650} \mathrm{Nem}$ sokkal később a BT az ENSZ Alapokmányának VII. fejezete alapján eljárva az ICC elé terjesztette a líbiai konfliktust.

Az Afrikai Unió másik „megoldási javaslata” a kérdés Nemzetközi Bíróság elé utalása, azaz tanácsadó véleményezési eljárás kezdeményezése az ENSZ bírói szerve elött. Mivel e sorok írásakor (még) nincs folyamatban eljárás az ICJ előttt, így annak kimeneteléről - egyáltalán a bíróságnak feltehető kérdésekről - nehéz szólni. Mindazonáltal Csapó Zsuzsanna meggyőzően érvel amellett, ${ }^{651}$ hogy az Afrikai Unió könnyebben meggyőzhető lenne egy „,független szakértő" véleménye által, semmint az ICC által kibocsátott verdiktekkel. 2018-ban

648 Du Plessis, 2012 [Online].

649 Order for Provisional measures, African Commission on Human and People's Rights v. Great Socialist Peop-

le's Libyan Arab Jamahiriya, App. No. 004/2011, (25 March 2011).

650 Oder, 2011, 495-510. o.

651 Csapó, 2019, 19-35. o. 
a tanácsadó vélemény kívánalma a Nemzetközi Büntetőbíróság esetjogában is feltűnt: a Dél-Afrika-határozathoz füzött különvéleményében ${ }^{652}$ Marc Perrin de Brichambaut a kérdés ICJ elé terjesztése mellett érvelt.

Azonban a tanácsadó vélemény születését is sok aggály övezi. Milyen fényt vetne az ICC hitelességére? Milyen hatással lenne a - kötelező erővel nem bíró - vélemény a szereplőkre: akár a Nemzetközi Büntetőbíróság, akár az Afrikai Unió követné az abban foglaltakat? S nem tûnne úgy, hogy a Nemzetközi Bíróság „pálcát tör” az ICC felett? A nemzetközi bírói fórumok egymásra hatása - vagy legalábbis a Nemzetközi Bíróság más nemzetközi bírói fórumokra hatása - a nemzetközi jog fejlődésének esszenciális lépcsőfoka, mely más jogterületeknél, így például az emberi jogoknál is kiemelt jelentőséghez jut. ${ }^{653} \mathrm{Az}$ interakció a nemzetközi büntetőjog fejlődése szempontjából kétségkívül áldásos lehetne, még ha a kérdés politikai vetületeit tekintve érzékeny is.

Ami pedig a Nemzetközi Bíróság által adható válaszokat illeti, Csapó Zsuzsanna logikus éleslátással szedi három csokorba az adható válaszokat aszerint, hogy (i) a Római Statútumban részes vagy nem részes államföjéről van szó; (ii) ki lenne köteles letartóztatni az államfőt; (iii) a Biztonsági Tanács kezdeményezte-e az eljárást. ${ }^{64}$

A fentieket kiegészítve érdemes lehet emlékezni az Állandó Nemzetközi Bíróság előtti Kelet-Karélia-ügyre:655 a PCIJ nem adott tanácsadó véleményt arra hivatkozva, hogy az állam beleegyezése előfeltétele a tanácsadó véleménynek olyan esetekben, melyek bilaterális jogvitákat érintenek. Bár a Kelet-Karélia-elvre a Nemzetközi Bíróság később közvetlenül sohasem hivatkozott, időről időre felmerült a bíróság esetjogában, különböző színezetet öltve. ${ }^{656}$ A kérdés csak az, hogy vajon a Nemzetközi Bíróság leporolná-e az elvet a vizsgált jogi probléma „horizontális hatálya” tekintetében? Vagy érdemi válasszal szolgálna?

652 Minority Opinion of Judge Marc Perrin de Brichambaut, elérhető: https://www.icc-cpi.int/RelatedRecords/ CR2017_04403.PDF [Letöltve: 2020. 02. 08.].

653 Raisz, 2009, 27. o.

654 Csapó, 2019, 28-29. o.

655 The Status of Eastern Carelia, Advisory Opinion, 7 February 1923, P.C.I.J. Series, No. 5.

656 Burton, 2019, 2. o. 


\subsection{A fellebbviteli tanács ítélete az al-Bashír-ügyben}

Al-Bashír 2017. március 29-én Ammánba utazott azért, hogy részt vegyen az Arab Liga csúcstalálkozóján. Jordánia - mint részes állam - a Római Statútum IX. fejezete alapján köteles lett volna a szudáni államföt ott-tartózkodása alatt letartóztatni [89. cikk (1) bekezdés ${ }^{657}$ ], aminek elmulasztása miatt „együtt nem múködési” eljárás indult ellene. Ennek során a tárgyalás-előkészítő tanács a Jordánia-határozatban ${ }^{658}$ megállapította, hogy az állam megszegte a Római Statútum szerint fennálló nemzetközi jogi kötelezettségeit, továbbá értesítette a Részes Államok Közgyưlését és a Biztonsági Tanácsot a közel-keleti országban történt incidensről a 87. cikk (7) bekezdése ${ }^{659}$ szerint. Emellett kimondta, hogy Szudán - bár nem részes fél a Római Statútumban - az 1593. (2005) BT-határozat értelmében ugyanúgy köteles együttmúködni a bírósággal, mintha az volna, és hogy a statútum 98. cikk (2) bekezdésére ${ }^{660}$ ez esetben nem lehet hivatkozni. ${ }^{661}$

Az elsőfokú határozat ellen Jordánia fellebbezést nyújtott be, ${ }^{662}$ így a bíróság történetében elsőként kerülhetett sor arra, hogy a fellebbviteli kamara állást foglaljon az „államfői immunitás vs. részes államok együttműködési kötelezettsége” kérdéséről, mely lehetőség több szempontból is különösen örvendetes. Az egyik ezek közül, hogy a Római Statútum 119. cikk (1) bekezdése ${ }^{663}$ értelmében az ICC-t megilleti az ún. hatáskör meghatározására vonatkozó hatáskör (compétence de la compétence), és mivel a fenti kérdés egyértelmúen ebbe

657 Római Statútum 89. cikk (1) bekezdés: „A Bíróság bármely olyan Államnak elöterjeszthet egy személy letartóztatására és átadására irányuló megkeresést, a kérelem alátámasztására szolgáló, a 91. cikkben meghatározott anyagokkal együtt, amelynek területén az adott személy található, és az adott Állam együttmúködését kéri az adott személy letartóztatása és átadása érdekében. A Részes Államok ajelen Fejezetrendelkezései és nemzeti eljárási szabályaik szerintteljesítik a letartóztatás és az átadás iránti kérelmet."

658 Decision under article 87(7) of the Rome Statute on the non-compliance by Jordan with the request by the Court for the arrest and surrender or Omar Al-Bashir, The Prosecutor v. Omar Hassan Ahmad Al-Bashir, ICC02/05-01/09, ICC Pre-Trial Chamber II, 11 December 2017 (a hivatkozásokban a továbbiakban: Jordánia-határozat).

659 Római Statútum 87. cikk (7) bekezdés: „Ha a Részes Állam a jelen Statútum rendelkezéseivel ellentétben nem tesz eleget a Bíróság együttmúködés iránti megkeresésének, és ezzel akadályozza a Bíróságot a jelen Statútumban meghatározott feladatai és hatásköre gyakorlásában, a Biróság megállapithatja ezt, és az ügyet a Részes Államok Közgyúlése elé terjesztheti, illetve ha Biztonsági Tanács utalta az ügyet a Bíróság elé, a Biztonsági Tanács elé utalhatja az ügyet."

660 Római Statútum 98. cikk (2) bekezdés: „A Bíróság nem terjeszthet elő olyan átadás iránti megkeresést, amely a Megkeresett Államot arra kényszerítené, hogy olyan nemzetközi szerzödéses kötelezettségével ellentétesen cselekedjen, amely szerint a küldő Állam hozzájárulása szükséges ahhoz, hogy az adott Államhoz tartozó személyt átadhassa a Bíróságnak, kivéve, ha a Bíróság előzetesen megszerzi a küldô Állam együttmüködését az átadáshoz szükséges hozzájáruláshoz."

661 Jordánia-határozat 32. \$.

662 The Hashemite Kingdom of Jordan's appeal against the "Decision under article 87(7) of the Rome Statute on the non-compliance by Jordan with the request by the Court for the arrest and surrender [of] Omar AlBashir", The Prosecutor v. Omar Hassan Ahmad Al-Bashir, ICC-02/05-01/09, ICC Appeals Chamber, 12 March 2018.

663 Római Statútum 119. cikk (1) bekezdés: „a Bíróság igazságszolgáltatási feladataival kapcsolatosan felmerülő bármely vitában a Bíróság dönt". 
a kategóriába esik, így az ICC hitelessége szempontjából szerencsés, ha nemcsak elvileg jogosult, de a gyakorlatban is lehetőséget kap rá, hogy ezen hatáskörével éljen. A másodfokú határozat másik pozitív hozadéka, hogy a fellebbviteli határozatok joggyakorlat-egységesítő hatása erősebb, azaz a tárgyalás-elôkészítő tanácsok számára is iránytúként szolgálhat a bíróság előtti jövőbeli esetek elbírálásához, a határozatok érvkészletének autoritásához.

A fellebbviteli tanácsnak - tekintélyes létszámú amicus curiae bevonása mellett ${ }^{664}$ - három fő szempontot kellett értékelnie a másodfokú ítélet meghozatala során. A fellebbezés első két pillérét tartalmi hasonlóságuk miatt - tudniillik hogy al-Bashír immunitást élvezett-e a nemzetközi jog alapján - a kamara egyhangúan és együttesen bírálta el, míg Jordánia harmadik érve - mely arra vonatkozott, hogy a tárgyalás-előkészítő tanács tévedett, amikor a jordániai incidenst az ASP és a BT elé terjesztette - kapcsán a többségi állásponthoz Luz del Carmen Ibáñez Carranza és Solomy Balungi Bossa bírák különvéleményt csatoltak. ${ }^{665}$

A fellebbezés első két pillérének elbírálásához a másodfokú tanács három szempontot mérlegelt, így (i) hogy az ország, melynek államfojjéről szó van, a Római Statútumnak nem részes állama; (ii) hogy ez az ország az ENSZ tagállama; és (iii) hogy a határozat, mely ezen államot az ICC elé utalta, az ENSZ Alapokmány VII. fejezete alapján született. ${ }^{666}$ Leegyszerúsítve, a bírák arra keresték a választ, hogy al-Bashír Szudán államfőjeként immunitást élvezett-e, vagy az együttmúködés kérése előtt az ICC-nek be kellett volna szereznie Szudántól a diplomáciai mentességről való lemondást? ${ }^{\text {?67 }}$

(i) A fellebbviteli tanács megvizsgálta, hogy létezik-e a szokásjogban ${ }^{68}$ olyan norma, amely meggátolja a bíróságot joghatósága gyakorlásában. Utóbbiról úgy ítélte meg, hogy különösen fontos a tárgyalás-előkészítő tanácsok esetjogát szétziláló inkoherencia leküzdése szempontjából. A kamara - a Yérodia-üggyel összhangban - megállapította, hogy a par in parem non habet imperium elvével összhangban valóban létezik olyan szokásjogi norma, amely a többi államnak megtiltja, hogy joghatóságot gyakoroljanak egy másik állam államfője felett (fôszabály), ${ }^{669}$ ellenben azt is megállapította, hogy a Római Statútum 27. cikk (2) be-

664 Az Afrikai Unió és az Arab Liga mellett Annalisa Ciampi, Paola Gaeta, Yolanda Gamarra, Claus Kreß, Flavia Lattanzi, Konstantinos D. Magliveras, Michael A. Newton, Roger O'Keefe, Darryl Robinson, Robert Cryer, Margaret de Guzman, Fannie Lafontaine, Valerie Oosterveld, Carsten Stahn, Nicholas Tsagourias és Andreas Zimmermann kapcsolódtak be az ügybe a „bíróság barátjaként”.

665 Joint Dissenting Opinion of Judge Luz del Carmen Ibáñez Carranza and Judge Solomny Balungi Bossa, elérhetô: https://www.icc-cpi.int/RelatedRecords/CR2019_02622.PDF [Letöltve: 2020. 05. 21.].

666 Jordánia-ítélet 96 . \$.

667 Jordánia-ítélet 97. \$.

668 A fellebbviteli tanács, bár rámutatott, hogy a fellebbezés a nemzetközi szokásjogra nem hivatkozik, úgy ítélte meg, hogy ennek vizsgálata szervesen kapcsolódik a mentesség fennállásáról való döntéshez. Lásd: Jordánia-ítélet 98-99. \$\$.

669 Jordánia másodfokú itélet 101., 114. \$\$. 
kezdésében lefektetett szabály (kivétel) több egy „közönséges” szerződéses normánál. Utóbbi tartalma szintén szokásjogi normát ${ }^{670}$ tükröz, azaz sem az egybevágó tartós gyakorlat, sem az opinio juris vizsgálata nem támasztja alá azon érvelést, hogy létezik olyan norma, mely a nemzetközi büntetőbíróságok joghatóság-gyakorlását államfők felett meggátolná (alkivétel hiánya). ${ }^{671}$ Ugyanakkor azt is kiemelte, hogy ezen alkivétel hiánya nem jelenti azt, hogy a főszabály nem jelent problémát az ICC letartóztatási parancsait végrehajtó államok és Szudán horizontális viszonyában. ${ }^{672} \mathrm{~A}$ fellebbviteli tanács felelevenítette a Malawi-határozat és a Taylor-ügy azon közös megállapítását, hogy a nemzetközi szokásjogban nem létezik olyan norma, mely elismeri az államfői mentességet a nemzetközi bíróságok joghatóság-gyakorlásával szemben. ${ }^{673}$

A 27. cikk (2) bekezdése és a 98. cikk egymáshoz való viszonyának áttekintése során a fellebbviteli tanács megerősítette a nemzetközi jogi mentességek vertikális hatálya (államok ICC) és horizontális hatálya (állam - állam) közötti különbséget, és elutasította Jordánia arra vonatkozó érvét, hogy a 27. cikk (2) bekezdése csak a bíróság joghatóság-gyakorlására vonatkozik, ám a letartóztatás foganatosítására és ICC-nek való átadásra már nem. ${ }^{674} \mathrm{Ez}$ abból is következik, hogy a bíróság joghatóságába tartozó bưncselekmények - mint például a népirtás - a nemzetközi jog legelemibb, ius cogens szabályainak megsértését szankcionálják, s mint olyanok, erga omnes együttmúködési kötelezettséget rónak az államokra e deliktumok megelőzése, üldözése és megbüntetése terén. ${ }^{675} \mathrm{~A}$ határozatban az is hangsúlyt kapott, hogy az együttmüködésre kötelezett részes államoknak az államfő́t nem saját joghatóság-gyakorlásuk céljából kellene letartóztatniuk, mert ilyen esetekben az ICC joghatóság-gyakorlásához nyújtanak segítséget. ${ }^{676}$

(ii) A fellebbviteli tanács érveinek második pillére az 1593. (2005) BT-határozat joghatásainak vizsgálatára vállalkozott, különös tekintettel az államfői immunitás kérdésére. A kamara rávilágított, hogy a 13. cikk b) pontja azért került bele a Római Statútumba, hogy a bíróság ezáltal segíthesse a Biztonsági Tanácsot az ENSZ Alapokmány VII. fejezet szerinti kötelezettsége, a nemzetközi béke és biztonság fenntartásában. Azt is kimondta, hogy a 13.

670 A 27. cikk (2) bekezdése szokásjogi természetének alátámasztásához a fellebbviteli kamara felidézte a nürnbergi elveket, a népirtás megelőzéséről és megbüntetéséről szóló 1948. évi New York-i egyezményt, az ICTY, ICTR és az SCSL statútumait, valamint a tárgyalás-előkészítő tanácsok joggyakorlatát. Lásd: Jordánia másodfokú itélet 100-119. \$\$.

671 Jordánia másodfokú itélet 116-117. \$\$.

672 Jordánia másodfokú itélet 120-132. \$\$.

673 Jordánia másodfokú itélet 109. \$.

674 Jordánia másodfokú itélet 122. \$.

675 Jordánia másodfokú itélet 123. \$.

676 Jordánia másodfokú itélet 127. \$. Lásd még: Joint Concurring Opinion of Judges Eboe-Osuji, Morrison, Hofmański and Bossa 387-413. \$\$, elérhető: https://www.icc-cpi.int/RelatedRecords/CR2019_02595.PDF [Letöltve: 2020.05 .21 .]. 
cikk b) pont gyakorlati előnye, hogy a BT-nek többé már nem szükséges új ad hoc büntető törvényszékeket felállítania, mert így az ICC lényegében véve bármikor „rendelkezésre áll” számára. 677

(iii) Továbbá a másodfokú kamara hangsúlyozta, hogy az 1593. (2005) BT-határozat valamennyi ENSZ-tagállam vonatkozásában kötelező erővel rendelkezik, függetlenül attól, hogy a Római Statútumnak részes államai-e, és ezzel párhuzamosan a határozatban szereplő teljes körú együttmúködési kötelezettség jogkövetkezményei kapcsán megjegyezte, hogy Szudánnak formálisan ugyanúgy együtt kell a bírósággal múködnie, mint ha a Római Statútum részes állama lenne. Mi több, a fellebbviteli tanács úgy látta, hogy a teljes körü együttmúködési kötelezettség a részes államok valamennyi olyan kötelezettségét felöleli, ami a bíróság hatékony joghatóság-gyakorlásához szükséges, és így magába olvasztja a 27. cikk (2) bekezdését is. ${ }^{678}$ Ennek alapján a fellebbviteli tanács kimondta, hogy a 98. cikk (1) bekezdése alapján Szudánnak nem kellett lemondani az államfői immunitásról a letartóztatási parancs végrehajtása előtt, minthogy az államfőii immunitás nem állt fenn. ${ }^{679}$

A másodfokú határozatot összegezve tehát elmondható, hogy a fellebbviteli kamara az 1593. (2005) BT-határozat 2. cikkéből indult ki, mely teljes körủ együttmúködési kötelezettséget állapított meg Szudán számára. E formulát pedig a másodfokú kamara kiterjesztően és teleologikusan értelmezve kiterjesztette valamennyi olyan esetre, ami az ICC hatékony fellépéséhez, a büntetlenség elleni harcban kapott mandátuma betöltéséhez szükséges. A Nemzetközi Büntetôbíróság kimondta, hogy bár Szudán nem részes állama a Római Statútumnak, a BT-határozatnak köszönhetően a bírósággal együtt kell múködnie. A fellebbviteli kamara Jordánia fellebbezését elutasította, a tárgyalás-előkészítő tanács határozatát helybenhagyta, és megállapította, hogy a közel-keleti állam megsértette a Római Statútum 87. cikk (7) bekezdéséből adódó kötelezettségét, amikor al-Bashír letartóztatását elmulasztotta. ${ }^{680}$

Jelen fejezet szemléletesen példázza, hogy a Biztonsági Tanács eljáráskezdeményezésekor a gyakorlatban leginkább problémásnak mutatkozó eset az együttmúködés és a nem részes államok magas rangú állami tisztviselőit megillető személyi immunitás keresztmetszetéből bontakozik ki, különösképpen al-Bashír korábbi szudáni elnök ügyének kö-

677 Jordánia másodfokú itélet 135. \$.

678 Jordánia másodfokú itélet 141-143. \$\$.

679 Jordánia másodfokú itélet 145-149. \$\$.

680 Jordánia másodfokú itélet $1-2$. \$\$. 
szönhetően. ${ }^{681}$ Minthogy Szudán nem részes fél a Római Statútumban, a dárfúri fegyveres konfliktus helyzetét a BT 1593. (2005) határozata utalta az ICC elé, a határozat 2. cikke pedig csak egyetlen harmadik államra, Szudánra rótt teljes körú együttmúködési kötelezettséget. Az együttmúködésről rendelkező rész kapcsán a bíróság a Kuvait-határozatban rámutatott, hogy bár hatásköreit tekintve a BT megtehette volna, a többi Római Statútumban nem részes államot nem kötelezi együttmúködésre, pusztán arra ösztönzi ôket. Ha azonban a határozat valamennyi harmadik állam számára elôírta volna az együttmúködést, a kötelezettség jogalapja közvetetten az ENSZ Alapokmányából nyerte volna erejét, mellyel számos jogalkalmazási és jogértelmezési vitának elejét lehetett volna venni. ${ }^{682}$ Utóbbiból pedig akad bőven, mivel az utóbbi kilenc évben az ICC tárgyalás-előkészítő tanácsai rendkívül széles skálán mozgó érvekkel próbálták alátámasztani az (akkori) szudáni államfő letartóztatásának jogszerûségét, az immunitás hiányát és a részes államok együttmúködési kötelezettségét.

Goran Sluiternél olvashatjuk, hogy a Biztonsági Tanács 1593. (2005) határozatának 2. cikke nem tisztázza egyértelmúen, hogy Szudán együttmúködési kötelezettségét a statútummal összhangban - és így a 27. cikk (1) és (2) bekezdésével összhangban - kell-e értelmezni. ${ }^{683}$ Ugyanakkor ez a feltevés könnyen cáfolható, ha figyelembe vesszük, hogy a Római Statútum adta jogszabályi keretrendszer az egyetlen, amelyen belül az ICC múködni képes. ${ }^{684}$ Ezt a Római Statútum 1. cikke is kihangsúlyozza: „a Biróság joghatóságát és múködését a jelen Statútum rendelkezései szabályozzák". Utóbbi szabály alól a statútum kivételt nem határoz meg, Így, ha egy konfliktus a Biztonsági Tanács közbenjárásának köszönhetően a bíróság elé kerül, akkor az egyetlen jogtechnikai lehetőség, ha onnantól kezdve rá nézve a Római Statútumot alkalmazzuk a pacta tertiis nec nocent nec prosunt elvét áttörve. Ezáltal értelemszerúen mind az anyagi és az eljárásjogi immunitás problémája, mind a részes és nem részes államok közötti horizontális viszonylatban alkalmazandó normák problémája áthidalhatóvá válna: a 27. cikk egyértelmúen eltörölné az immunitást, valamint az a probléma sem merülne fel, hogy mivel Szudán nem részes állama a statútumnak, ezért egy részes állam és Szudán vonatkozásában a nemzetközi szokásjogot kell alkalmazni. Másfelől meggyőző a fellebbviteli tanács által a Jordánia-itéletben megfogalmazott azon elvi tétel is, hogy az államoknak erga omnes kötelezettsége áll fenn a nemzetközi búncselekmények elleni harcban tanúsítandó együttmúködésre nézve, amit a Római Statútum Preambulumában szintén olvashatunk,

681 Ellentétben például az előző fejezetben bemutatott komplementaritással, melynek problémái nem kifejezetten a Biztonsági Tanács által az ICC elé vitt helyzetek sajátjai, minthogy a kiegészítő joghatóság feltételrendszerének valamennyi eljárást kezdeményező mechanizmus esetén fenn kell állnia, azaz utóbbi esetén állandóan visszatérő jogalkalmazási kérdésről van szó.

682 Kuvait-határozat 9. \$.

683 Sluiter, 2008, 876-877. o.

684 Akande, 2009, 334. o.; de Wet, 2015, 1058. o. 
miszerint a részes felek megerősítik azt, hogy „[...] a nemzetközi közösség egészét érintő legsúlyosabb büntettek nem maradhatnak büntetlenül, és a hatékony felelösségre vonást nemzeti intézkedésekkel és a nemzetközi együttmúködés erösitése révén kell biztositani”.

Bár a fellebbviteli tanács érvelésében e gondolattal nem találkozhatunk, fontos megjegyezni, hogy az ENSZ Alapokmány 2. cikk (5) bekezdése a nemzetközi jog alapelvei között rögzíti az együttmúködési kötelezettséget, miszerint: „A Szervezet összes tagjai az Egyesült Nemzetek részére a jelen Alapokmánynak megfelelóen folytatott bármely tevékenységéhez minden segitséget megadnak és tartózkodnak attól, hogy segitséget nyújtsanak olyan Államnak, amely ellen az Egyesült Nemzetek megelőző vagy kényszerítő intézkedéseket foganatosit." Mind az együttmüködési kötelezettségre vonatkozó rendelkezés nyelvtani, mind teleologikus értelmezését tekintve megállapíthatjuk, hogy a BT-határozat hallgatása ellenére az Alapokmány maga rögzíti az együttmúködési kötelezettséget valamennyi ENSZ-tagállam - így többek között Szudán - vonatkozásában is. S bár a jogviták eldöntése pusztán alapelvekre hivatkozva nehezen járható út, a helyes jogértelmezéshez szilárd fogódzót adnak a kezünkbe.

Az együttmúködés elvéből adódó kötelezettség az al-Bashír ellen kiadott letartóztatási parancsok végrehajtása során is jelentkezik az államok oldalán, mi több, mint Alapokmányból származó kötelezettség primátust élvez bármely más nemzetközi jogi kötelezettségükkel szemben. ${ }^{65}$ Jelen ügy tükrében az ENSZ Alapokmány 2. cikk (5) bekezdése tehát az alábbiak szerint értelmezhető: (i) „a Szervezet összes tagjai”, azaz Szudán, a Római Statútumban egyéb nem részes és részes államok; (ii) „az Egyesült Nemzetek részére a jelen Alapokmánynak megfelelően folytatott bármely tevékenységéhez", azaz a VII. fejezet alapján meghozott BT-határozat végrehajtásához; (iii) „minden segítséget megadnak”, azaz letartóztatják al-Bashirt; és (iv) „tartózkodnak attól, hogy segítséget nyújtsanak olyan Államnak”, azaz elmulasztják al-Bashír letartóztatását; (v) „amely ellen az Egyesült Nemzetek megelőző vagy kényszerítő intézkedéseket foganatosít”, azaz a 41. cikk értelmében az ICC elé utalja a dárfúri helyzetet.

Ugyanakkor, ha az együttmüködési kötelezettség fennállásának fenti hipotézisei - mint ahogyan arra a Jordánia-itéletben a fellebbviteli kamara is rámutatott - fel is oldanák a jogalkalmazási dilemmákat, és a jogirodalomban gerjesztett viták elcsendesülnének, attól még ott maradna a „politikai dimenzió” kőkemény és rideg valósága, amely arra enged következtetni, hogy a nemzetközi elfogatóparancsok végrehajtása továbbra is hosszasan és következetesen váratna magára...

685 Lásd emlékeztetőül újfent az ENSZ Alapokmány 103. cikkét: „Ha az Egyesült Nemzetek tagjainak a jelen Alapokmányból folyó és bármely egyéb nemzetközi megállapodásból eredő kötelezettségei összeütköznének, az Alapokmányból folyó kötelezettségeiket illeti elsóbbség." 
IV.

RÉSZ

Összegzés 
Jelen kötet a Biztonsági Tanács által a Nemzetközi Büntetőbíróság elé utalt helyzetek legfontosabb jogi problémáinak bemutatására vállalkozott. Bár e - nemzetközi jogászok között méltán sokat tárgyalt és vitákra alapos okot adó - téma első látásra gazdag forrásbázissal kecsegteti a lelkes kutatót, a munka előrehaladtával és a megválaszolásra szoruló kérdések letisztultabbá válásával egyidejűleg a vizsgálódó egyfelől azzal is kénytelen szembesülni, hogy a tengernyi szakirodalom dacára nem áll az elemzés alá vont jogi normák [Római Statútum 13. cikk b) pont, 15bis és 15ter cikkek, valamint 16. cikk] mögött bevett állami gyakorlat, azokra a Biztonsági Tanács alig hivatkozik. Másfelől pedig, még ha hivatkozik is rájuk, a vonatkozó rendelkezéseket nem arra használja fel, mint amire a jogalkotói szándék eredetileg predesztinálta őket, hanem a néhány gyakorlati példából egyértelmúen az látszik, hogy a BT - egyéb hatásköreihez hasonlóan - politikai ágendák teljesítésére próbálja használni mind a nemzetközi büntető igazságszolgáltatást, mind a Nemzetközi Büntetőbíróságot.

Utóbbi a bíróság intézményi autonómiája, függetlensége, pártatlansága és alapvetően a jogbiztonság követelménye szempontjából ugyancsak aggályos, s még ha az ICC csak „szenvedő alanya” is a Biztonsági Tanács ilyenfajta törekvéseinek, mentesülni alóluk és az általuk kiváltott utóhatásoktól aligha tud. Gondoljunk csak például az al-Bashir-ügy és az Afrikai Unió által gerjesztett politikai hullámverésre a letartóztatási parancsok végrehajtása körül, a líbiai helyzet „fénysebességư” Nemzetközi Büntetôbíróság elé utalására, az agresszió bû́ncselekményének Római Statútumba foglalása körüli eposzi hosszúságú vitákra és a megszületett rendelkezések gyakorlati alkalmazásának reális esélyeire, vagy a 16. cikk gyakorlati alkalmazására, a nem részes államok békefenntartóinak jövőbeli „absztrakt” mentesítésére. A továbbiakban a kutatás tézisei a mú szerkezetét, az egyes részek és fejezetek sorrendjét követve kerülnek összegzésre, melyek fényében a Biztonsági Tanács által a Nemzetközi Büntetôbíróság elé utalt helyzetekkel kapcsolatban az alábbi kép rajzolódott ki.

Elsőként megállapíthatjuk, hogy a nemzetközi büntetőbíróságok létrehozásában való állami részvétel, illetve a nemzetközi büntetőbíróságok joghatóság-gyakorlásához adott állami beleegyezés esetén az adott büntetőbírói fórum autoritását és legalitását mind az esetjogban, mind a jogtudományban kevesebb bírálat éri, mivel így az állami szuverenitást féltő aggályok kiiktathatók. A nemzetközi jog tudományában mára már köztudomású ténynek mondható, hogy az ICC nem az első büntetőbírói fórum, melyet a BT-hez szoros kapcsolat füz. A történeti előzmények között említhetô az ICTY és az ICTR - utóbbiakkal a Biztonsági Tanács kapcsolata olyannyira szoros, hogy a két törvényszéket a BT 827. (1993) és 955. (1994) határozatai hozták létre -, „kortárs” példaként pedig az STL hozható fel, melynek - a Libanon és az ENSZ fő́titkárának közremüködésével szövegezett és a libanoni parlament által ratifikálni megakadályozott - statútumát végül az 1757. (2007) BT-határozat léptette hatályba. E törvényszékeket a többi nemzetközi büntetőbírósággal (SCSL, ECCC stb.) párhuzamba állítva elmondható, hogy minél kevésbé vett részt a konfliktussal érintett állam 
a bírói fórum létrehozásában, azaz minél erősebb külső beavatkozás nyomán született meg a bíróság (lásd: ICTY), annál inkább felerősödnek a törvényszék létrehozásának jogszerúségét kétségbe vonó hangok - a contrario, minél inkább bevonnak egy államot a bíróság létrehozásába, annál nagyobb a valószínúsége, hogy a későbbiek során a nemzetközi fórummal együtt fog múködni. (Már amennyiben bevonható az állam a nemzetközi büntető igazságszolgáltatás „aktiválásába”, hiszen ez sok esetben egyáltalán nem jöhet számításba, lásd újfent az ICTY példáját.)

Másodikként leszögezhetjük, hogy egy nemzetközi büntetőbíróság felállításának legideálisabb módja az, ha nemzetközi szerződéssel hozzák létre, ugyanakkor nyilvánvaló, hogy a tömeges emberi jogi és humanitárius jogsértésekért felelős állami vezetők, magas rangú tisztviselők felelősségre vonása és országuk önkéntes csatlakozása egy büntetőbírói fórumot létrehozni hivatott statútumhoz igencsak csekély. Utóbbi probléma áthidalása érdekében került bele a Római Statútumba annak 13. cikk b) pontja, nevezetesen, hogy a Biztonsági Tanács az ENSZ Alapokmányának VII. fejezete - tekintetet nélkül az elkövetés helyére vagy az elkövetó állampolgárságára - helyzeteket utalhat az ICC elé, amennyiben alapos okkal feltételezhetô, hogy a bíróság ratione materie joghatóságába tartozó bûntetteket követtek el a Római Statútum hatálybalépése - 2002. július 1., illetve az agresszió bűncselekménye esetén 2018. július 17. - után.

Harmadikként rögzíthetjük, hogy a Biztonsági Tanács Nemzetközi Büntetőbíróság előtti eljáráskezdeményező hatásköre az ENSZ Alapokmány 41. cikke alapján foganatosítható nem fegyveres kényszerintézkedések körébe tartozik. A Biztonsági Tanács nemzetközi büntető igazságszolgáltatásban játszott szerepének megvonásánál - a BT egyéb hatásköreihez hasonlóan - értelemszerúen az Egyesült Nemzetek Alapokmányából kell kiindulni, a Biztonsági Tanács és a Nemzetközi Büntetőbíróság kapcsolatának mögöttes jogalapját pedig az ENSZ Alapokmány 39. és a 41. cikkei teremtik meg. Utóbbi tükrében elmondható, hogy a Biztonsági Tanács Római Statútum 13. cikk b) pontjába, illetve 15ter cikk (1) bekezdésébe foglalt hatáskörei az ENSZ Alapokmány 41. cikke alatti nem fegyveres kényszerintézkedések bővíthető körébe tartoznak. A „kényszerítő” jelleg ilyen esetekben ott érhető tetten, hogy a BT határozatai értelmében a Római Statútumot olyan államokra kell alkalmazni, amelyet ezen államok nem fogadtak el, illetőleg nem ratifikáltak. (Jóllehet elméletben az is előfordulhatna, hogy a BT olyan állam helyzetét utalja a Nemzetközi Büntetőbíróság elé, mely a részes fél a Római Statútumban, erre azonban a gyakorlatban jelen sorok írásáig nem volt példa.)

Negyedikként számba kell vennünk, hogy a Római Statútum a Nemzetközi Büntetôbíróság és a Biztonsági Tanács kapcsolatát két pillérre helyezi: a BT eljáráskezdeményezésére (13. cikk b) pont, illetve 15ter cikk) és eljárásfelfüggesztésére (16. cikk). A Nemzetközi Büntetőbíróság és a Biztonsági Tanács kapcsolatának normatív kereteit közvetve - a már fentebb is említett - ENSZ Alapokmány, valamint közvetlenül a Római Statútum normái határozzák 
meg. Bár e rendelkezések szerinti gyakorlati esetek száma kevés, annál több problémát rejtenek. Utóbbit szemléletesen példázza, hogy a 13. cikk b) pontja alapján idáig csak két esetben indult eljárás az ICC elôtt (2005-ben dárfúri humanitárius katasztrófa, 2011-ben a líbiai arab tavasz okán), és e helyzetekből származó ügyek egyike sem jutott el az ítélethozatalig az érintett államok, valamint a Római Statútumban részes államok együttmúködésének hiányában. A vonatkozó BT-határozatokban - 1593. (2005) és 1970. (2011) - foglaltak az érdemi büntetőeljárások lehetőségének gátat szabnak a finanszírozás és a joghatóság kizárásával, továbbá az ENSZ-tagállamok együttmüködési kötelezettségét kimondó rendelkezések mellőzésével. A két pillért illetôen azt lehet látni, hogy az eddigi utalások alkalmával a BT - néhol hatásköreinek túllépése, néhol ki nem használása mellett - bár eljárásokat indított az ICC előtt, az eljárások rögös útját - a bírósági felülvizsgálat alá nem vonható, így adott esetben jogellenesnek ki nem mondható határozataival - determinálta.

A jelen kötetben bemutatott kutatás ötödik megállapítása, hogy az ICC agresszió bưncselekménye feletti eljárási képessége sui generis joghatósági rendszert képez egy sui generis joghatósági rendszerben - mely kiváltképpen a részes államok és a fơügyész által indított eljárásokra igaz, és ami a bíróság időbeli, személyi és területi joghatóságára vonatkozó különbségekből, valamint az eljárás megindításának előfeltételeire vonatkozó többletfeltételekből adódik. Ugyanakkor megjegyzendő, hogy e sui generis joghatósági rendszer a Biztonsági Tanács által ICC elé vitt helyzetekben kevésbé sajátságos a másik két eljárást indító mechanizmushoz képest, minthogy a BT-t a joghatósági korlátok közül egyedül az aktiváláshoz szükséges 30 ratifikáció és a visszamenő hatály tilalma köti. A Biztonsági Tanács agresszió bưncselekményével kapcsolatos hatáskörei a Római Statútum rezsimjét ismételten áttörik, azaz a szerződéses normák meghajolnak a nemzetközi béke és biztonság imperatívusza előtt. Az ICC agresszió feletti joghatóságáról azt mondhatjuk, hogy az némiképp egyszerúbbnek tûnik - legalábbis az absztrakció és a jogi normák szintjén - a BT indította eljárásokban, mint a részes államok utalásai és a proprio motu búnvádi eljárások viszonylatában.

Hatodikként meg kell említenünk, hogy a Római Statútum hatálybalépése óta eltelt közel két évtizedben a 16. cikk „rendeltetésszerû” alkalmazására még nem került sor, és e rendelkezés gyakorlati „múködése” ugyancsak szerény. A BT eddig kétszer függesztette fel az ICC előtti „eljárást” [1422. (2002) és 1487. (2003) határozatok], azonban egyik eset sem a rendelkezés valódi célját szolgálta, tudniillik hogy a konfliktusos államok a tartós béke előmozdítása érdekében az eljárás felfüggesztésével időt nyerjenek. A 16. cikk szerinti eljárások mindkét alkalommal az Egyesült Államok politikai akaratát juttatták érvényre úgy, hogy a rendelkezés alkalmazási feltételei - az Alapokmány 39. cikke szerinti nemzetközi béke és biztonság veszélyének fennforgása, valamint konkrét eljárás fennállása - nem teljesültek, azaz az 1422. (2002) és 1487. (2003) határozatok absztrakt, pro futuro jelleggel születtek. Így 
azt mondhatjuk, hogy a Római Statútum 16. cikke „rendeltetésszerư” alkalmazásának még nincs gyakorlata.

Hetedikként érdemes rögzíteni, hogy a Biztonsági Tanács által a Nemzetközi Büntetőbíróság elé utalt helyzetek érintettjei a gyakorlatban harmadik államok - azaz a Római Statútumban nem részes felek -, így esetjogi tapasztalatok a Római Statútumban részes államok BT által történt ICC elé terjesztésével, az ilyen eljárások „dinamikájával” kapcsolatban egyáltalán nem mutathatók fel. Ezért szükséges, hogy a harmadik államok Római Statútumhoz való viszonyát kifejezetten számba vegyünk. Arra juthatunk, hogy a harmadik felek Római Statútumban való jogállása négyféle perspektívából vizsgálható: ezek közül az első a harmadik államok - relatíve széles körú - jogai, továbbá a bíróság objektív jogalanyisága (mint valamennyi állam fennálló kötelezettsége), a harmadik államok beálló kötelezettségei, valamint a harmadik államok kötelezettségnek nem minősülő jogi érintettsége.

A kutatás nyolcadik megállapítása, hogy az ICC elôtti ügyek tényleges elfogadhatósága sokkal valószínúbb a BT indította eljárásokban, mivel így az érintett államnak kevesebb idő áll rendelkezésére az állami bíróság előtti érdemi büntetőeljárás megindítására, illetve érdemi eljárási cselekmények foganatosítására. A komplementaritás érvényesülése, az egyes ügyek elfogadhatósága újabb gócpontként jelentkezett a BT által kezdeményezett eljárásokban. (Pontosabban a BT által kezdeményezett eljárásokban is, mivel a komplementaritás gyakorlati értelmezése a bíróság joghatóságának ex officio vizsgálata során valamennyi ügyben felmerül.) Az ICC és a BT relációjában elmondható, hogy a kiegészítő joghatóság elve alapján az ICC előtti eljárások tényleges elfogadhatósága - azaz a helyi hatóságok hajlandóságának és képességének a hiánya - sokkal valószínúbb akkor, ha az ENSZ főszerve indítja meg a bíróság eljárását, különös tekintettel az idő rövidségére, mely az érintett államoknak ilyen esetekben rendelkezésére áll.

Kilencedikként megjegyzendő, hogy az esetjogban helyenként fellelhető inkoherencia a nemzetközi büntetőbírósági joggyakorlat egyik - jogbiztonsági aggályokat sejtető, ám szükségszerû - attribútuma, mely a jogterület újszerűségéből adódóan az egyes fogalmak gyakorlati kimunkálásának sajátos negatív hozadéka. A komplementaritással kapcsolatban a Szajf Kadhafi és Abdullah al-Senussi ügyeiböl levonható következtetésként jelentkezik e tanulság számunkra.

Tizedikként szólni kell arról, hogy a Római Statútum 27. cikke és 98. cikk (1) bekezdése közötti normakonfliktus csak látszólagos, azt a Nemzetközi Büntetôbíróság a Jordánia-ítéletben feloldotta. A kutatás során egyértelmúvé vált, hogy a nemzetközi (büntető)jogi szakirodalmat leginkább az együttmúködés, a nemzetközi elfogatóparancsok végrehajtása és a Biztonsági Tanács által kezdeményezett eljárások kérdésköre osztja meg, mely az államfői immunitás jogintézménye által „megszínezve” hosszan tartó nehézségeket okozott az ICC joggyakorlatában (lásd Omar al-Bashír ügyét) a Római Statútum 27. cikke és 98. cikk (1) be- 
kezdése között - látszólag - feszülő normakonfliktus miatt. Az ICC valamennyi, a 87. cikk (7) bekezdése szerinti eljárásban kimondta a letartóztatási parancsok végrehajtásának kötelezettségét a részes államok - így például a kötetben is vizsgált Malawi, Csád, Kongói Demokratikus Köztársaság, Dél-afrikai Köztársaság és Jordánia - oldalán, ugyanakkor ezt egymásnak ellentmondó érvekre hivatkozva, a koherens bírói esetjog kialakítását mellőzve tette. A fenti normakonfliktus feloldása a Nemzetközi Büntetőbíróság esetjogának egyik legnagyobb kihívása volt, amit az ún. Jordánia-itéletben sikerült tisztáznia. Ez ügyben a fellebbviteli kamara - sommásan - kimondta, hogy bár Szudán nem részes állama a Római Statútumnak, a Biztonsági Tanács 1593. (2005) határozata értelmében rá a Római Statútumot - és annak 27. cikkét - alkalmazni kell, így az államfő́i immunitás anyagi és eljárásjogi expressis verbis eltörlése az afrikai államra is vonatkozik (és így normakonfliktus esete nem állhat fenn).

Végül, a kutatás utolsó megállapításaként rögzítendő, az ICC előtti jogalkalmazási kérdések eldöntésére az ICC hivatott, így egy tanácsadó vélemény kérése a Nemzetközi Bíróságtól az al-Bashir-ügyben gyengítené a Nemzetközi Büntetôbíróság hitelességét és pozícióját a nemzetközi jogrendben. Az al-Bashír-ügy a regionális politikában hatalmas feszültséget gerjesztett: az Afrikai Unió a volt szudáni elnök elleni első letartóztatási parancs kibocsátása után (2009) azon nyomban felszólalt a kontinens belügyeibe való beavatkozás okán, illetve az eljárás felfüggesztésére is törekedett a Római Statútum 16. cikkében megfogalmazott lehetőséget kihasználva. Az afrikai államok együttmúködési kötelezettségének hiánya - részben - a regionális nemzetközi szervezet által generált politikai feszültség következménye, melynek megoldását az AU az Ember és Népek Jogainak Afrikai Bírósága joghatóságának kiterjesztésében és a Nemzetközi Bíróságtól való tanácsadó vélemény kérésében látja. Noha az ICJ tanácsadó véleményei a nemzetközi jogban a jogi normák értelmezésének jótékony segédeszközeként szolgálnak, a Római Statútum 119. cikk (1) bekezdésének fényében felmerül, hogy szerencsés-e, ha a kérdésben nem a Nemzetközi Büntetőbíróság foglal állást? Az ún. hatáskör meghatározására vonatkozó hatáskör (compétence de la compétence) elvének tükrében a statútum kimondja a bíróság esetjogában jelentkező igazságszolgáltatási kérdések eldöntésére való kompetenciáját, azaz hogy az ICC igazságszolgáltatási feladataival kapcsolatosan felmerülő bármely vitában az ICC dönt. Egy tanácsadó vélemény kérése az ICJ-től azonban - még ha annak ereje "csupán” ajánlási értékú is - esetlegesen újabb kritikai hangokat erősíthet fel a Nemzetközi Büntetőbíróság hatáskörének hiányát sugallva, valamint további, az ICC hitelességét és a nemzetközi színtéren ôt illető potenciált tovább csorbítva. (Utóbbi pedig fokozottan igaz lenne akkor, ha a Nemzetközi Bíróság az ICC fellebbviteli tanácsa által a Jordánia kötelezettségszegése kapcsán kimondottakkal szembehelyezkedne.)

A levont következtetések alapján a Nemzetközi Büntetőbíróság és a Biztonsági Tanács kapcsolatáról elmondható, hogy e koncepció - az ICTY és az ICTR által hátrahagyott örökség 
szellemében - mint az ICC „kvázi ad hoc ága” jóllehet költséghatékonyság és időtakarékosság szempontjából a római diplomáciai konferencián kecsegtető megoldásnak látszott, a büntetlenség korával való leszámolás tekintetében számottevô eredményekkel az elmúlt 23 esztendőben nem szolgált.

Ennek legfőbb oka a BT átható politikai karakterében keresendő, amely leegyszerúsítve két problémakört von maga után. Az egyik, hogy az ICC előtt kezdeményezett eljárások szelektívek - a Biztonsági Tanács egyfajta „á la carte” megközelítést alkalmaz -, minthogy az eddigi esetek alapján a külső szemlélőkön megalapozottan lehet úrrá az a benyomás, hogy a Biztonsági Tanács sokszor nem gyakorolja a Római Statútum 13. cikk b) pontja alatt található jogosultságát akkor, amikor kellene. Másfelől a megindított eljárások - Dárfúr és Líbia - tekintetében elmondható, hogy azok kihívásaival a bíróságnak egyedül, „félkarú óriásként" kell megküzdenie, mivel a Biztonsági Tanács a vonatkozó határozataiban a bíróság joghatóságát leszúkítette, a bíróságtól a finanszírozást megvonta, az ENSZ-tagállamokat együttmüködésre fel nem szólította, a későbbiekben pedig az ICC határozatainak, letartóztatási parancsainak végrehajtását esetleges ún. follow-up határozatok formájában nem támogatta.

Bár az „agressziós eljárások” gyakorlatának hiányában a Római Statútum 15bis és 15ter cikkeibe foglalt joghatósági rendszer múködőképességéről csak spekulatívan lehet állást foglalni, a szabályozás komplexitása, a joghatósági előfeltételek sokasága, valamint az agresszió cselekménye és az agresszió bű́ncselekménye szükségszerủ összefonódásának lehetséges politikai kihatásai egyértelmúen arra engednek következtetni, hogy egy ilyen eljárás megindításának valószínûsége a belátható jövőben igencsak csekély.

A két intézmény kapcsolatának másik pillére, a Római Statútum 16. cikkében testet öltő eljárások felfüggesztése szintén nem tudta az eredetileg hozzá füzött jogpolitikai célokat beteljesíteni, mivel eddig a Biztonsági Tanács csupán olyan esetekben hivatkozott rá, amelyek a jogalkotó eredeti szándékával nem állnak összhangban.

Az eddigi gyakorlat alapján megállapítható, hogy még ha a Biztonsági Tanács él is a 13. cikk b) pontjában testet öltő hatáskörével, az eljárás további folyása során a büntetőbírói fórumot teljesen magára hagyja, az ICC pedig a BT-határozatok és a Római Statútum által teremtett normatív keretek, valamint az Afrikai Unió által gerjesztett politikai feszültség pókhálójába gabalyodva - stílszerűen - bár hajlandó lenne, de nem képes eljárni.

Emellett azonban a realitások talaján állva azt is látni kell, hogy a BT kezdeményezte eljárások lehetősége, valamint a 16. cikkben foglaltak beemelése a Római Statútumba az ICC megszületésének szükségszerủ előfeltételei voltak, s e rendelkezések mellőzése esetén ma minden bizonnyal nem beszélhetnénk állandó Nemzetközi Büntetőbíróságról. 



\section{Mellékletek}

\section{A Római Statútum részes államai 2021-ben ${ }^{686}$}

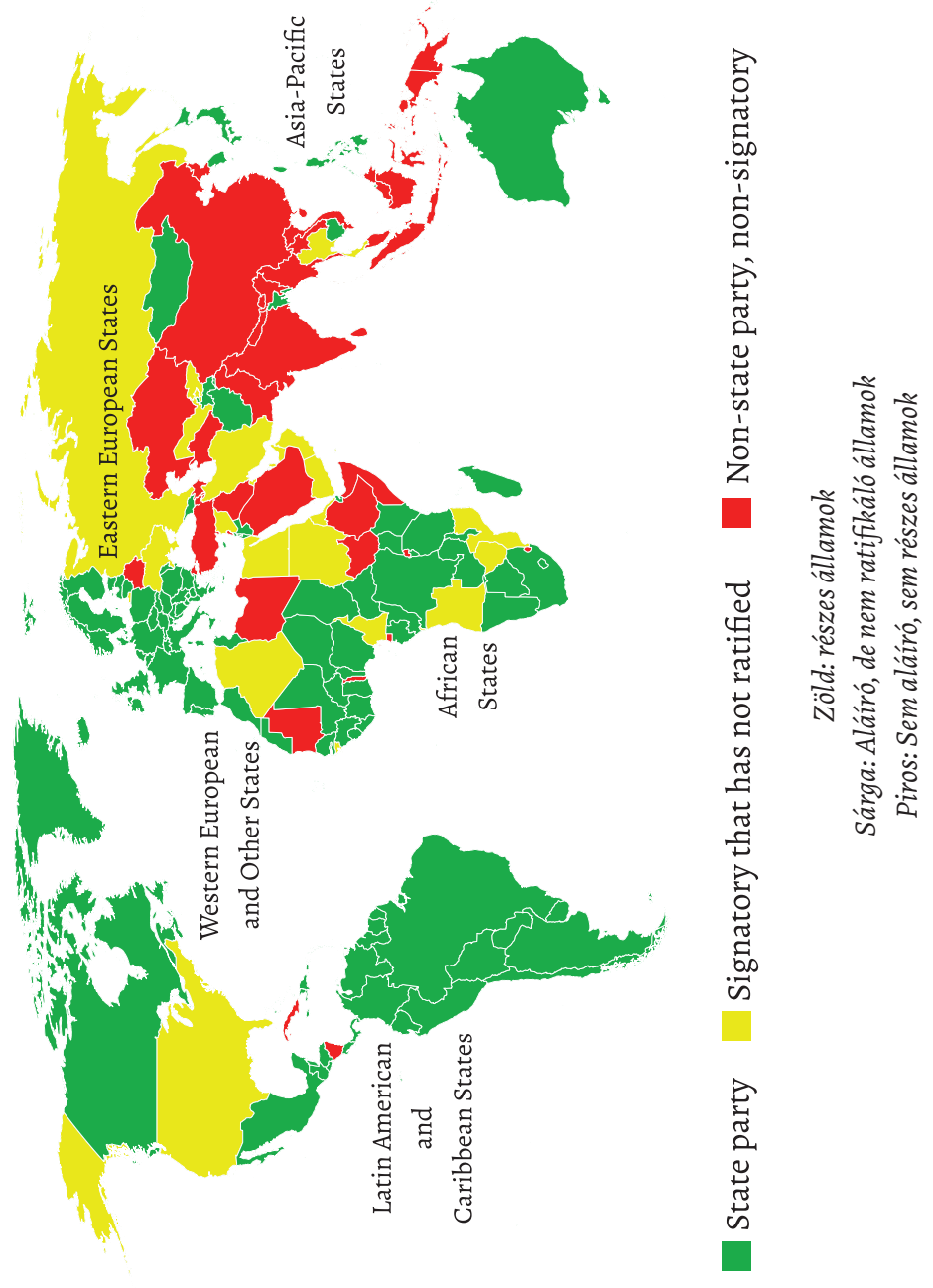

686 A térkép a Nemzetközi Büntetőbíróság honlapjáról származik. Elérhető: https://asp.icc-cpi.int/en_menus/ asp/states $\% 20$ parties/pages/the\%20states $\% 20$ parties $\% 20$ to\%20the\%20rome\%20statute.aspx [Letöltve: 2021. 04. 22]. 


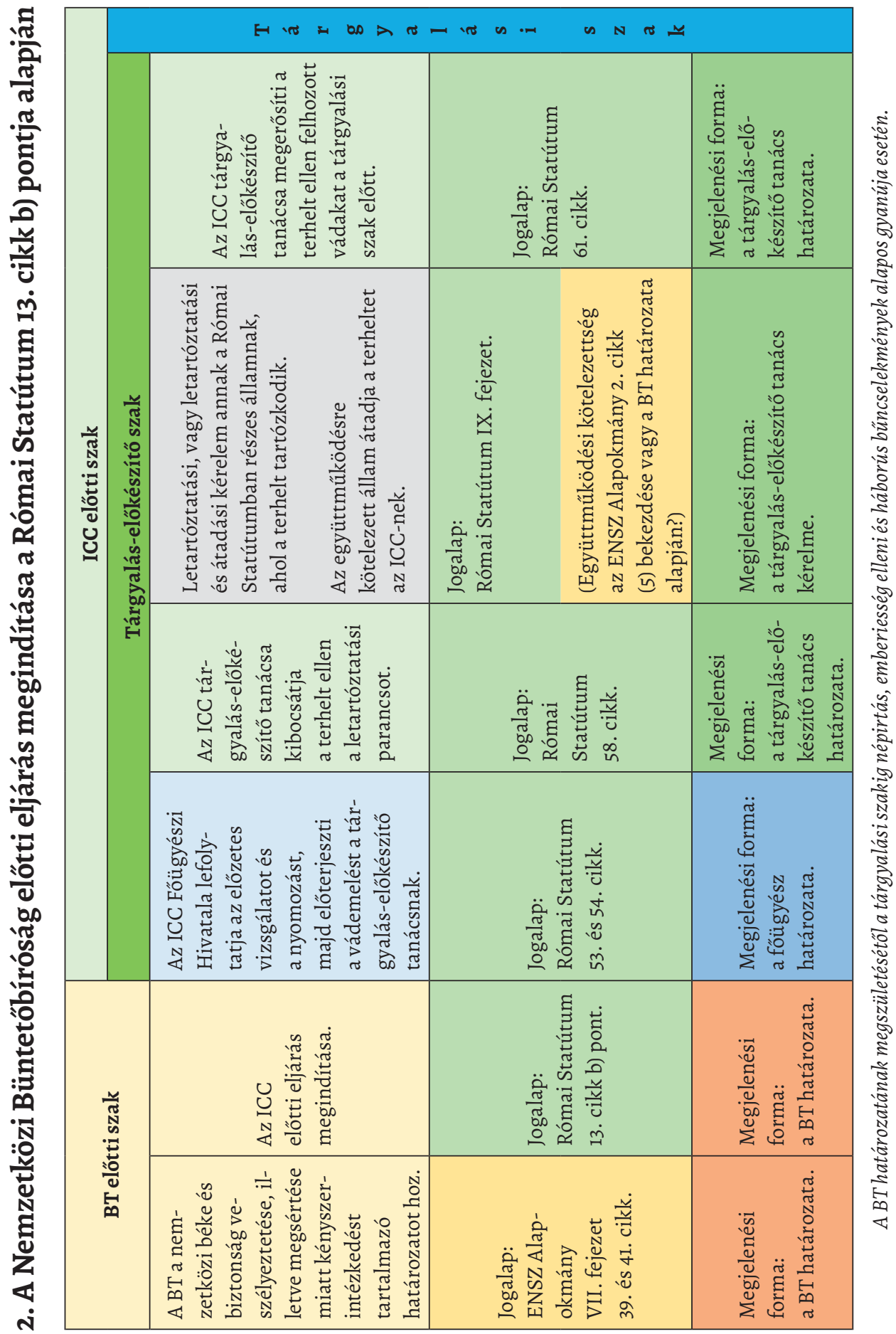




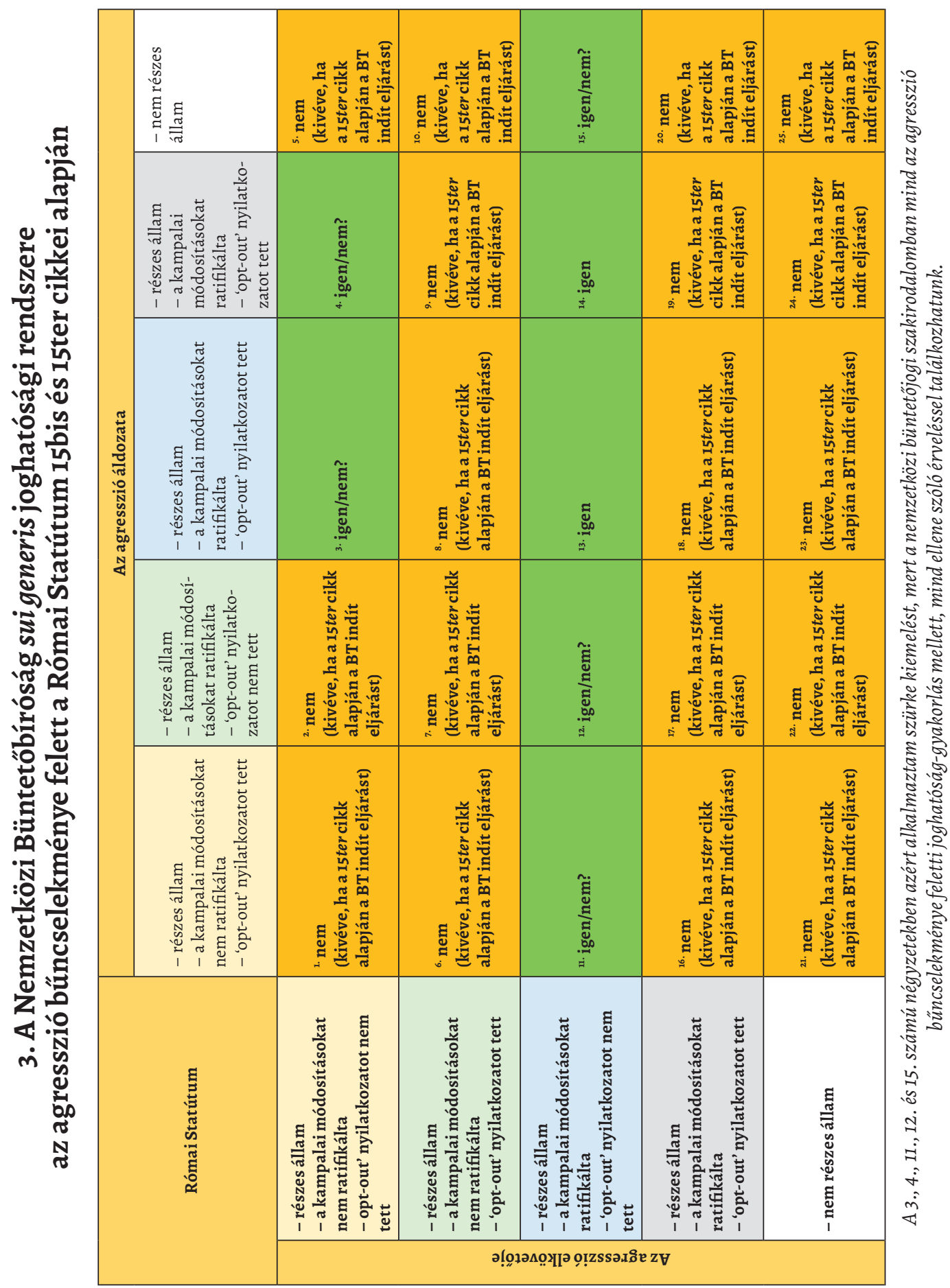




\section{Az immunitásprobléma horizontális és vertikális hatályának szemléltetése}

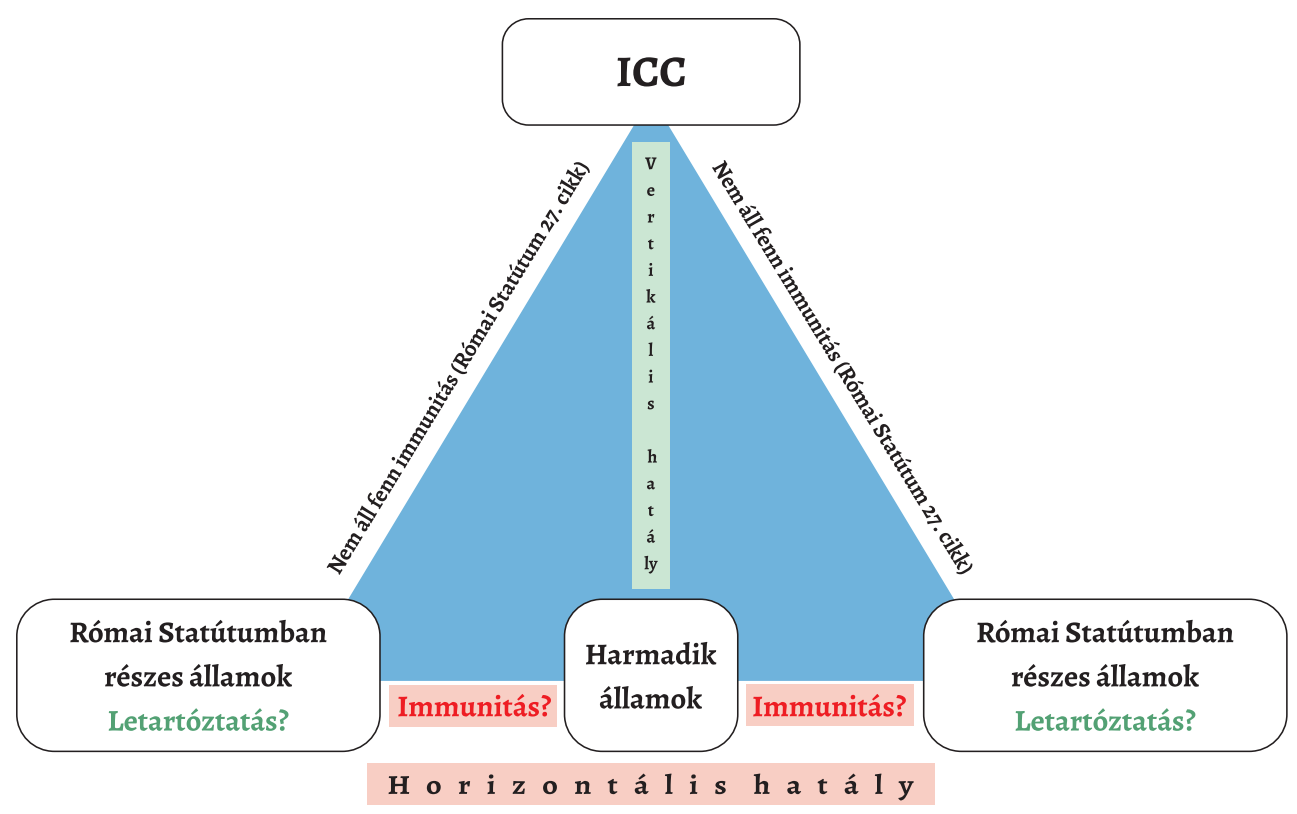




\section{Felhasznált források és irodalom}

ÁDÁNY, T. V. (2014) A Nemzetközi Büntetöbiróság joghatósága. Előzmények, tendenciák és elōfeltételek. Budapest: Pázmány Press.

ÁDÁNY, T. V. (2018) 'Nemzetközi büntetőbíróságok' in Lamm, V. (szerk.) Emberi jogi enciklopédia. Budapest: HVG-ORAC Lap- és Könyvkiadó Kft.

AjAMI, F. (2012) The Arab Spring at One: A Year of Living Dangerously [Online]. Elérhető: https:// www.foreignaffairs.com/articles/syria/2012-01-24/arab-spring-one [Letöltve: 2021. 04. 21.].

AKANDE, D. (2004) 'International Law Immunities and the International Criminal Court', American Journal of International Law, 98(3), 407-433. o.; DOI: https://doi.org/10.2307/3181639.

Akande, D. 'Prosecuting Aggression: The Consent Problem and the Role of the Security Council', Oxford Legal Studies Research Paper, 2011/10 [Online]. Elérhető: https://papers. ssrn.com/sol3/papers.cfm?abstract_id=1762806 [Letöltve: 2021 . 06. 29.].

AkANDE, D. (2003) 'The Jurisdiction of the International Criminal Court over Nationals of Non-Parties: Legal Basis and Limits', Journal of International Criminal Justice, I(3), 618-650. o.; https://doi.org/10.1093/jicj/1.3.618.

AKANDE, D. (2009) 'The Legal Nature of Security Council Referrals to the ICC and Its Impact of Al Bashir Immunities', Journal of International Criminal Justice, 7(2), 333-352. o.; https:// doi.org/10.1093/jicj/mqpo34.

AKandE, D., Tzanakopoulos, (2018) A. 'Treaty Law and ICC Jurisdiction Over the Crime of Aggression', European Journal of International Law, 29(3), 939-959. o.; https://doi.org/10.1093/ ejil/chyo59.

Akhavan, P. (2016) 'Complementarity Conundrums. The ICC Clock in Transitional Times', Journal of International Criminal Justice, 14(5), 1043-4059. o.

AL-RAshidi, M. (2012) 'The Special Court for Sierra Leone and the Special Tribunal for Lebanon: Lessons to Be Learned from the Establishment, Composition and Jurisdiction of an International Tribunal', Ankara Law Review, 9(1), 1-25. o.; https://doi.org/10.1501/ Lawrev_0000000083.

ALVAREZ, J. E. (1996) 'Nuremberg Revisited: The Tadić Case', European Journal of International Law, 7(2), 245-264. o.

APTEL, C. (2007) 'Some Innovations in the Statute of the Special Tribunal for Lebanon', Journal of International Criminal Justice, 5(5), 1107-1124. o.; https://doi.org/10.1093/jicj/mqmo66 
ARbour, L. (2013) Doctrine Derailed: Internationalism's Uncertain Future [Online]. Elérhető: https://www.crisisgroup.org/global/doctrines-derailed-internationalism-s-uncertainfuture [Letöltve: 2021. 04. 21.].

ARbour, L. (2014) 'The Relationship between the ICC and the UN Security Council', Global Governance, 20(2), 195-201. o.; https://doi.org/10.1163/19426720-02002002.

ARNould, V. (2017) Court in Crisis? The ICC in Africa, and Beyond [Online]. Elérhető: http://www. egmontinstitute.be/content/uploads/2017/05/EP93.pdf?type=pdf [Letöltve: 2021.04 . 21.]. Arsanjani, M., Resiman, M. (2005) 'The Law in Action of the International Criminal Court', American Journal of International Law, 99(2), 385-403. o.

BÁBA, I., SÁRINGER J. (főszerk.) (2018) Diplomáciai lexikon. Budapest: Éghajlat Könyvkiadó $\mathrm{Kft}$.

BÉRES, N. (2015) 'Az ICC joggyakorlatának kezdeti kihívásai: a dárfúri helyzet a nemzetközi büntető́bírói fórum előtt' in Bragyova, A. (szerk.) Studia Iurisprudentiae Doctorandorum Miskolciensium. Miskolci Doktoranduszok Jogtudományi Tanulmányai. Miskolc: Gazdász Elasztik Kft.

BÉRES, N. (2015) 'Gondolatok a Nemzetközi Büntetőbíróság joghatóságának vitás kérdéseiról', Publicationes Universitatis Miskolcinensis Sectio Juridica et Politica, 33(1), 203-212. o.

BÉRES, N. (2019) 'Törésvonalak a nemzetközi elszámoltathatóság terén. A Nemzetközi Büntetốbíróság és az Afrikai Unió viszonya', Állam-és Jogtudomány, 60(1), 5-18. o.

Bergsmo, M., Perić, J. (2008) 'Article 16 ' in Triffterer, O. (ed.) Commentary on the Rome Statute of the International Criminal Court Observers' Notes, Article by Article. Baden-Baden: Nomos.

BesenYő, J. (2016) Dárfúr, a lángoló tartomány. Az Afrikai Unió szudáni missziójának története. Pécs: Publikon Kiadó.

Bishop, A. (2013) 'Failure of Complementarity: The Future of the International Criminal Court Following the Libyan Admissibility Challenge', Minnesota Journal of International Law [online]. Elérhető: https://core.ac.uk/download/pdf/217211031.pdf [Letöltve: 2021 . 06. 30.]. BLOKKeR, N., KRess, C. (2010) 'A Consensus Agreement on the Crime of Aggression: Impressions from Kampala', Leiden Journal of International Law, 23(4), 889-895. o.

Boschiero, N. (2015) 'The ICC Judicial Finding on Non-Cooperation Against the DRC and No Immunity for Al-Bashir Based on UNSC Resolution 1593', Journal of International Criminal Justice, 13(3), 625-653. o.

BRUHÁCs, J. (2001) Nemzetközi jog III. Nemzetközi szervezetek. Budapest-Pécs: Dialóg Campus Kiadó.

BuRton, P. (2019) 'Searching for the Eastern Carelia Principle', ESIL Reflections [online]. Elérhetô: https://esil-sedi.eu/esil-reflection-searching-for-the-eastern-carelia-principle/ [Letöltve: 2021. 06. 30.].

CASSESE, A. (2008) International Criminal Law. Oxford: Oxford University Press. 
CASsese, A. (1998) 'On the Current Trends towards Criminal Prosecution and Punishment of Breaches of International Humanitarian Law', European Journal of International Law, 9(1), 2-17. o.; https://doi.org/10.1093/ejil/9.1.2

CAssese, A., Gaeta, P., Jones, J. R. W. D. (2002) The Rome Statute of the International Criminal Court. Oxford: Oxford University Press.

ClARK, R. S. (2010) 'Amendments to the Rome Statute of the International Criminal Court Considered at the First Review Conference on the Court, Kampala, 31 May-11 June 2010', Goettingen Journal of International Law, 2(2), 689-711. o.

Clark, R. S. (2015) 'The Crime of Aggression' in Carsten Stahn (ed.) The Law and Practice of the International Criminal Court. Oxford: Oxford University Press.

Cline, C. T. (2008) 'Perspectives of a Non-Party to the International Criminal Court Treaty', Transnational Law and Contemporary Problems, 17(1), 107-121. o.

Corten, O., KleIn, P. (ed.) (2011) The Vienna Conventions on the Law of Treaties. A Commentary. Oxford: Oxford University Press.

Crawford, J. (1994) 'The ICL's Draft Statute for an International Criminal Tribunal', American Journal of International Law, 88(1), 140-152. 0.; https://doi.org/10.2307/2204031.

CRAWford, J. (1995) 'The ICL Adopts a Statute for an International Criminal Court', American Journal of International Law, 89(2), 404-416. o.; https://doi.org/10.2307/2204214.

CRYer, R., Friman, H., Robinson, D., Wilmshurst, E. (2016) An Introduction to International Criminal Law and Procedure. Cambridge: Cambridge University Press.

CRYer, R. (2015) 'The ICC and its Relationship to Non-States Parties' in Carsten Stahn (ed.) The Law and Practice of the International Criminal Court. Oxford: Oxford University Press.

CRYER, R. (2006) 'Sudan, Resolution 1593, and International Criminal Justice', Leiden Journal of International Law, 19(1), 195-222. o.; https://doi.org/10.1017/S0922156505003237.

CsAPó Zs. (2012) 'A Nemzetközi Büntetőbíróság és az ENSZ Biztonsági Tanácsának viszonyrendszere a Római Statútum 16. cikkének fényében', Kül-Világ. A nemzetközi kapcsolatok folyóirata, 9(4), 42-59. o.

CsAPó Zs. (2019) 'Az állam- és kormányfői immunitás versus a hivatali minőség irrelevanciájának elve a felelősségre vonáskor. Az Afrikai Unió kezdeményezése tanácsadó vélemény kérésére a Nemzetközi Bíróságtól', Állam-és Jogtudomány, 60(1), 19-35. o.

DE Wet, E. (2015) 'The Implications of President Al-Bashir's Visit to South Africa for International and Domestic Law', Journal of International Criminal Justice, 13(5), 1049-1071. 0.; https://doi.org/10.1093/jicj/mqvo58.

Dickinson, L. A. (2003) 'The Promise of Hybrid Courts', American Journal of International Law, 97(2), 295-310. o.; https://doi.org/10.2307/3100105.

Dipalo, S. (2018) 'The Security Council's Non-Determination of a Threat to the Peace as a Breach of International Law', Pécs Journal of International Law [Online]. Elérhető: http:// 
ceere.eu/pjiel/wp-content/uploads/2018/08/63_pjielPJIEL1801.pdf [Letöltve: 2021. 06. 30.].

DunlaP, B. (2004) 'State Failure and the Use of Force in the Age of Global Terror', International Law and Comparative Law Review, 27(2), 453-475. o.

Du Plessis, M. (2012) Implications of the AU Decision to Give the African Court of Jurisdiction over International Crimes [Online]. Elérhető: https://issafrica.s3.amazonaws.com/site/uploads/ Paper235-AfricaCourt.pdf [Letöltve: 2021. 04. 21.].

Du Plessis, M. (2009) 'Recent Cases and Developments: South Africa and the International Criminal Court', South African Journal of Criminal Justice, 22(3), 441-446. o.

El ZeIDY, M. (2002) 'The United States Dropped the Atomic Bomb of Article 16 of the ICC Statute: Security Council Power of Deferrals and Resolution 1422', Vanderbilt Journal of Transitional Law, 35(1), 1503-1544. o.

Esakov, G. (2017) 'International Criminal Law in Russia: Missed Crimes Waiting for Revival', Journal of International Criminal Justice, 15(2), 371-392. o.; https://doi.org/10.1093/jicj/ mqX007.

Fassbender, B. (2008) 'Friede durch Recht. Hans Kelsen und die Vereinten Nationen' in Brunkhorst, H., Voigt, R. (eds.) Rechts-Staat. Baden-Baden: Nomos.

FASSBENDER, B. (2007) 'Reflections on the International Legality of the Special Tribunal for Lebanon', Journal of International Criminal Justice, 5(5), 1091-1105. o.; https://doi.org/10.1093/ jicj/mqmo7o.

FEHL, C. (2014) Growing Up Rough: The Changing Politics of Justice at the International Criminal Court [Online]. Elérhető: https://www.hsfk.de/fileadmin/HSFK/hsfk_downloads/prif127. pdf [Letöltve: 2021. 04. 21.].

FIfE, R. E. (2000) 'The International Criminal Court - Whence It Came, Where It Goes', Nordic Journal of International Law, 69(1), 63-85. o.; https://doi.org/10.1163/15718100020296198.

GaEta, P. (2009) 'Does President Al Bashir Enjoy Immunity from Arrest?', Journal of International Criminal Justice, 7(2), 315-332. o.; https://doi.org/10.1093/jicj/mqpo30.

Gaeta, P. (2002) 'Official Capacity and Immunities' in Cassese, A., Gaeta, P., Jones, J. R. W. D. (eds.): The Rome Statute of the International Criminal Court: A Commentary. Oxford: Oxford University Press.

GAETA, P. (2014) The ICC Changes its Mind on the Immunity from Arrest of President Al Bashir, But It Is Wrong Again [Online]. Elérhető: http://opiniojuris.org/2014/04/23/guest-post-icc-changes-mind-immunity-arrest-president-al-bashir-wrong/ [Letöltve: 2021. 04. 21.].

Galbraith, J. (2003) 'The Bush Administration's Response to the International Criminal Court', Berkeley Journal of International Law [Online]. Elérhető: https://scholarship.law. upenn.edu/cgi/viewcontent.cgi?article=2450\&context=faculty_scholarship [Letöltve: 2021. 06. 30.]. 
GalbRAith, J. (2013) 'Treaty Options: Towards a Behavioral Understanding of Treaty Design', Virginia Journal of International Law [Online]. Elérhető: https://scholarship.law.upenn.edu/ cgi/viewcontent.cgi?referer $=\&$ httpsredir $=1 \&$ article $=2456 \&$ context=faculty_scholarship [Letöltve: 2021. 06. 30.].

GANCZER, M. (2011) 'Az állampolgárság fogalma és összetevői napjainkban', Jog - Állam - Politika, 3(2), 65-85. o.

GioIA, F. (2006) 'State Sovereignty, Jurisdiction, and "Modern" International law: The Principle of Complementarity in the International Criminal Court', Leiden Journal of International Law, 19(4), 1095-1123. o.; https://doi.org/10.1017/S0922156506003761.

Gramer, R. (2016) Why Russia Just Withdrew from the ICC [Online]. Elérhetô: https://foreignpolicy.com/2016/11/16/why-russia-just-withdrew-from-icc-putin-treaty-ukraine-law/ [Letöltve: 2021. 04. 21.].

GreENWOOD, C. (1996) 'International Humanitarian Law and the Tadić case', European Journal of International Law, 7(2), 265-283. o.

Guilfoye, D. (2017) The International Criminal Court Independent Expert Review: reforming the Court: Part I [Online]. Elérhető: https://www.ejiltalk.org/the-african-unions-collectivewithdrawal-from-the-icc-does-bad-law-make-for-good-politics/ [Letöltve: 2021. 04. 21.].

GuT, P. (2020) Ítélet a gonosz felett. Ben Ferencz - a nürnbergi föügyész élete és szenvedélyes harca az igazságért. Budapest: Európa Kiadó.

HÁrs, A. (2018) 'Nemzetközi szervezetek határozatai' in Jakab, A., Fekete, B. (szerk.) Internetes Jogtudományi Enciklopédia (Nemzetközi jog rovat, rovatszerkesztő: Sulyok, G.) [Online]. Elérhetô: https://ijoten.hu/szocikk/nemzetkozi-szervezetek-hatarozatai [Letöltve: 2021. 04. 21.].

HeLfer, L. R., SHOWALter, A. E. (2017) 'Opposing International Justice: Kenya’s Integrated Backlash Strategy Against the ICC', International Criminal Law Review [Online]. Elérhetô: https://scholarship.law.duke.edu/cgi/viewcontent.cgi?article=6404\&context=faculty_ scholarship [Letöltve: 2021 . 06. 30.].

Heller, K. J. (2013) 'A Few Thoughts on a Syria Referral', Opinio Juris Blog [Online]. Elérhetô: http://opiniojuris.org/2013/01/14/a-few-thoughts-on-a-syria-referral/ [Letöltve: 2021. 04. 21.].

HELleR, K. J. (2013) 'Can the Security Council Implicitly Amend the Rome Statute?', Opinio Juris Blog [Online]. Elérhető: http://opiniojuris.org/2013/o1/15/can-the-security-councilimplicitly-amend-the-rome-statute/ [Letöltve: 2021. 04. 21.].

HeLleR, K. J. (2010) 'Opt-Ins and Opt-Outs', Opinio Juris Blog [Online]. Elérhetô: http://opiniojuris.org/2010/06/21/opt-ins-and-opt-outs/ [Letöltve: 2021. 04. 21.].

Hillard, L., Shendruk, A. (2020) Funding the United Nations: What Impact Do U.S. Contributions Have on UN Agencies and Programs? [Online]. Elérhető: https://www.cfr.org/article/ 
funding-united-nations-what-impact-do-us-contributions-have-un-agencies-andprograms [Letöltve: 2021.04 .21$.$] .$

HIRAD, A. (2005) 'The Islamic Republic of Iran and the ICC', Journal of International Criminal Justice, 3(3), 635-648. o.; https://doi.org/10.1093/jicj/mqio50.

HоввS, H. O. (2012-2013) 'The Security Council and the Complementarity Regime of the International Criminal Court. Lessons from Libya', Eyes on the ICC [Online]. Elérhetô: https:// www.perkinscoie.com/images/content/3/1/v2/31293/IWCD-13-11-EyesontheICC-Funk. pdf [Letöltve: 2021.06 .30$.$] .$

HOFFMANN, T. (2009) 'A fegyveres konfliktus minősítési problémái a polgárháborúba történő külföldi katonai beavatkozás esetén' in Kirs, E. (szerk.) Egységesedés és széttagolódás a nemzetközi büntetőjogban. Miskolc: Bíbor Press.

HoffmanN, T. (2019) 'Contra aggressionem? Az agresszió büncselekményével kapcsolatos nemzetközi jogi dilemmák', Állam-és Jogtudomány, 60(1), 36-68. o.

Holmes, J. (1999) 'The Principle of Complementarity' in Lee, R. (ed.) The International Criminal Court. The Making of the Rome Statute. Kluwer Law International.

IGWE, C. S. (2008) 'The ICC's Favourite Customer: Africa and International Criminal Law', The Comparative and International Law Journal of Southern Africa, 41(2), 294-323. o.

IvERSON, J. (2012) 'The Continuing Functions of Article 98 of the Rome Statute', Goettingen Journal of International Law, 4(1), 131-151. o.; https://doi.org/10.3249/1868-1581-4-1-iverson.

JACoBs, D. (2011) A Sad Hommage to Antonio Cassese: The ICC's Confused Pronouncements on State Compliance and Head of State Immunity [Online]. Elérhetô: https://dovjacobs.com/2011/12/15/ a-sad-hommage-to-antonio-cassese-the-iccs-confused-pronouncements-on-statecompliance-and-head-of-state-immunity/ [Letöltve: 2021. 04. 21.].

JaCoBs, D. (2015) 'The Frog that Wanted to Be an Ox. The ICC's Approach to Immunities and Cooperation' in Stahn, C. (ed.) The Law and Practice of the International Criminal Court. Oxford: Oxford University Press.

JACOBS, D. (2013) Why the Vienna Convention should not be Applied to the ICC Rome Statute: A Plea for Respecting the Principle of Legality [Online]. Elérhető: https:/dovjacobs.com/2013/08/24/whythe-vienna-convention-should-not-be-applied-to-the-icc-rome-statute-a-plea-for-respecting-the-principle-of-legality/ [Letöltve: 2021. 04. 21.].

JAIN, N. (2005) 'A Separate Law for Peacekeepers: The Clash between the Security Council and the International Criminal Court', European Journal of International Law, 16(2), 239-254. o.; https://doi.org/10.1093/ejil/chi116

Johnstone, I. (2003) 'Security Council Deliberations: The Power of the Better Argument', European Journal of International Law, 14(3), 437-480. o.; https://doi.org/10.1093/ejil/14.3.437.

Kardos, G. (2006) 'Konstrukció és destrukció a nemzetközi bíráskodásban', Jogtudományi Közlöny, 61(6), 238-241. o. 
KAYE, D. et al. (2013) The Council and The Court: Improving Security Council Support of the International Criminal Court [Online]. Elérhető: https://cpb-us-e2.wpmucdn.com/sites.uci.edu/ dist/9/798/files/2013/05/The-Council-and-the-Court-FINAL.pdf [Letöltve: 2021. 04. 21.].

KecskÉs, G. (2018) 'Emberi jogok védelmének afrikai rendszere' in Lamm, V. (szerk.) Emberi jogi enciklopédia. Budapest: HVG-ORAC Lap- és Könyvkiadó Kft.

Kelly, M. (2011-2012) 'The Debate Over Genocide in Darfur, Sudan', University of California, Davis Journal of International Law and Policy, 18(1), 205-223. 0.

Kirsch, P., Holmes, J. T. (1999) 'The Rome Conference on an International Criminal Court: The Negotiating Process', American Journal of International Law, 93(1), 2-12. o.; https://doi. org/10.2307/2997952.

KIRS, E. (2012) 'A Nemzetközi Büntetőbíróság és a bűnszervezeti felelősségi koncepció halála', Kül-Világ. A nemzetközi kapcsolatok folyóirata, 9(4), 87-97. o.

KIRs, E. (2009) A tényfeltáró és békéltetô bizottságok helye a nemzetközi büntetőjogifelelősségre vonás intézményrendszerében, PhD-értekezés. Miskolci Egyetem Állam- és Jogtudományi Kar.

KIRs, E. (2018) 'Az ICTY által megalkotott bûnszervezeti felelősségi koncepció élete és remélt halála', Állam- és Jogtudomány, 59(1), 57-77. o.

KIRs, E. (2018) Tettesek és bünrészesek a délszláv háborúban. Gotovina, Perišić, Šešeljés Orićfelmentésének nemzetközi büntetőjogi háttere. Budapest: L'Hartmann Kiadó.

KovÁcs, P. (2019) 'A Nemzetközi Büntetőbíróság és az államok együttmúködése: szabályok, sikerek, nehézségek, kihívások és realitások', Miskolci Jogi Szemle, 14(2), (különszám, 2. kötet), 85-96. o.

KovÁcs, P. (2020) Bevezetés a Nemzetközi Büntetóbíróság joggyakorlatába. Budapest: Pázmány Press.

KovÁcs, P. (2019) 'Miért nincs még kihirdetve a Római Statútum? Gondolatok a Római Statútum és az Alaptörvény összeegyeztethetőségének egyszerûségéről', Állam- és Jogtudomány, 60(1), 69-90. (Kovács, 2019a).

KovÁcs, P. (2018) 'Nemzetközi büntetőbíráskodás' in Jakab, A., Fekete, B. (szerk.) Internetes Jogtudományi Enciklopédia (Nemzetközi jog rovat, rovatszerkesztő: Sulyok, G.) [Online]. Elérhető: https://ijoten.hu/szocikk/nemzetkozi-buntetobiraskodas\#_ftnref2 [Letöltve: 2021. 04. 21.].

KovÁcs, P. (2016) Nemzetközi közjog, Budapest: Osiris Kiadó.

Kovács, P. (2019b) 'On the Specificities of the International Legal Personality of the International Criminal Court' in Szabó, M., Láncos, P. L., Varga, R. (eds.) Hungarian Yearbook of International and European Law. The Hague: Eleven International Publishing.

KovÁcs, P. (2017) 'The International Criminal Court as an International Judicial Control of the National Public Power? (The ICC's Standpoint on the Complementarity Principle in the Prosecutor v. Simone Gbagbo Case)' in Arnold, R., Martínez, J. I. (eds.) Rule of Law, 
Human Rights and Judicial Control of Power. Some Reflections from National and International Law. Springer International Publishing.

KRESS, C. (2012) 'The International Criminal Court and Immunities under International Law for States Not Party to the Court's Statute' in Bergsmo, M., Yan, L. (eds.) State Sovereignty and International Criminal Law. Beijing: FICHL Publication Series, No. 15, Torkel Opsahl Academic EPublisher.

Kress, C., Prost, K. (2008) 'Article 98 - Cooperation with Respect to Waiver of Immunity and Consent to Surrender' in Triffterer, O. (ed.) Commentary on the Rome Statute of the International Criminal Court Observers' Notes, Article by Article. Baden-Baden: Nomos.

Kress, C., von Holtzendorff, L. (2010) 'The Kampala Compromise on the Crime of Aggression', Journal of International Criminal Justice, 8(5), 1179-1217. 0.; https://doi.org/10.1093/ jicj/mqq069.

LABUDA, P. (2017) The African Union's Collective Withdrawal from the ICC: Does Bald Law Make for Good Politics? [Online]. Elérhetô: https://www.ejiltalk.org/the-african-unions-collectivewithdrawal-from-the-icc-does-bad-law-make-for-good-politics/ [Letöltve: 2021. 04. 21.].

LAtTmanN, T. (2009) 'A nemzetközi büntetôbírói fórumok múködésének rendszere, különös tekintettel a Nemzetközi Büntetőbíróságra - politika, parancs vagy jog?' in Kirs, E. (szerk.) Egységesedés és széttagolódás a nemzetközi büntetőjogban. Miskolc: Bíbor Press.

LaVAlLE, R. (2003) 'A Vicious Storm in a Teacup: The Action by the United Nations Security Council to Narrow the Jurisdiction of the International Criminal Court', Criminal Law Forum, 14(1), 195-220. o.

LIETZAU, W. K. (2001) 'The United States and the International Criminal Court: International Criminal Law after Rome: Concerns from U.S. Military Perspective', Law and Contemporary Problems, 64(1), 119-120. o.; https://doi.org/10.2307/1192356.

MARINKÁs, Gy. (2018) Az öslakos népek védelmének aktuális jogi kihívásai. Miskolc: Miskolci Egyetem Állam- és Jogtudományi Kar.

Maunganidze, O. A., Du Plessis, A. (2015) 'The ICC and the AU' in Stahn, C. (ed.) The Law and Practice of the International Criminal Court. Oxford: Oxford University Press.

MAYER, A. (2012-2013) 'Building the New Libya: Lessons to Learn and to Unlearn', University of Pennsylvania Journal of International Law, 34(2), 365-387. o.

McDougall, C. (2013) The Crime of Aggression Under the Rome Statute of the International Criminal Court. Cambridge: Cambridge University Press.

MÉGRET, F. (2008) 'A Special Tribunal of Lebanon: The UN Security Council and the Emancipation of International Criminal Justice', Leiden Journal of International Law, 21(2), 485512. o.; https://doi.org/10.1017/S0922156508005062. 
MÉGRET, F. (2001) 'Epilogue to an Endless Debate: The International Criminal Court's Third Party Jurisdiction and the Looming Revolution of International Law', European Journal of International Law, 12(2), 247-268. o.

MÉgRet, F., SAMSON, M. G. (2013) 'Holding the Line on Complementarity in Libya', Journal of International Criminal Justice, 11(3), 571-589. o.; https://doi.org/10.1093/jicj/mqto35.

Milanović, M. (2012) 'Aggression and Legality Custom in Kampala', Journal of International Criminal Justice, 10(1), 165-187. 0.; https://doi.org/10.1093/jicj/mqro54.

Milanović, M. (2011) 'Is the Rome Statute Binding on Individuals? (And Why We Should Care)', Journal of International Criminal Justice, 9(1), 25-52. o.; https://doi.org/10.1093/jicj/ mqq070.

Mistry, H., VerduZCo, D. R. (2012) The UN Security Council and the International Criminal Court [Online]. Elérhetô: https:/www.chathamhouse.org/sites/default/files/public/Research/ International\%20Law/160312summary.pdf [Letöltve: 2021. 04. 21.].

Mokhtar, A. (2003) 'The Fine Art of Arm-Twisting: The US, Resolution 1422 and Security Council Deferral Power Under the Rome Statute', International Criminal Law Review, 3(4), 295-344. o.; https://doi.org/10.1163/157181203322584396.

Moss, L. (2012) The UN Security Council and the International Criminal Court: Towards a More Principal Relationship [Online]. Elérhető: http://library.fes.de/pdf-files/iez/08948.pdf [Letöltve: 2021. 04. 21.].

Newton, M. A. (2001) 'Domestic Jurisdiction Consistent with the Rome Statute of the International Criminal Court', Military Law Review, 167(167), 20-73. o.

Nikolova, M., Ventura, M. J. (2013) 'The Special Tribunal for Lebanon Declines to Review UN Security Council Action. Retreating from Tadić's Legacy in the Ayyash Jurisdiction and Legality Decisions', Journal of International Criminal Justice, 11(3), 615-641. o.; https:// doi.org/10.1093/jicj/mqto24.

Oder, J. (2011) 'The African Court on Human and People's Rights' Order in Respect of the Situation in Libya: A Watershed in the Regional Protection of Human Rights?', African Human Rights Law Journal, 11(2), 495-510. o.

Oкеснuкwu, O. (2008) 'The Challenges of International Criminal Prosecutions in Africa', Fordham International Law Journal, 31(2), 343-414. o.

PAPEnfuss, T. (2013) The Relationship between the ICC and the Security Council: Challenges and Opportunities [Online]. Elérhető: https://www.ipinst.org/2013/03/the-relationship-between-the-icc-and-the-security-council-challenges-and-opportunities [Letöltve: 2021. 04. 21.].

RaIsz, A. (2010) 'Az emberi jogok amerikaközi védelme', Publicationes Universitatis Miskolcinensis Sectio Juridica et Politica, 28(1), 281-295. o. 
RAISZ, A. (2009) Az Emberi Jogok Európai és Amerikaközi Bíróságának egymásra hatása, PhD-értekezés. Miskolci Egyetem Állam- és Jogtudományi Kar.

RAIsz, A. (2017) 'Az önálló nemzetközi környezetjogi bíráskodás létjogosultságáról', Miskolci Jogi Szemle, 12(2), 449-455. o. (2. különszám).

RAMANATHAN, U. (2005) 'India and the ICC', Journal of International Criminal Justice, 3(3), 627634. o.; https://doi.org/10.1093/jicj/mqio55.

RASTAN, R. (2015) 'Jurisdiction' in Stahn, C. (ed.) The Law and Practice of the International Criminal Court. Oxford: Oxford University Press.

REINISCH, A. (2009) 'Should Judges Second-Guess the UN Security Council?', International Organizations Law Review, 6(1), 257-291. o.; https://doi.org/10.1163/157237409X464260.

REISINGER Coracini, A. (2010) 'The International Criminal Court's Exercise of Jurisdiction Over the Crime of Aggression - At Last... In Reach... Over Some', Goettingen Journal of International Law, 2(2), 745-789. o; https://doi.org/0.3249/1868-1581-2-2-Reisinger.

Robinson, D. (2015) 'Inescapable Dyads: Why the ICC Cannot Win', Leiden Journal of International Law, 28(2), 323-347. o.; https://doi.org/10.1017/S0922156515000102.

Rosand, E. (2004) 'The Security Council as "Global Legislator": Ultra Vires or Ultra Innovative?', Fordham International Law Journal, 28(3), 542-590. o.

Roscini, M. (2006) 'The Efforts to Limit the International Criminal Court's Jurisdiction over Nationals of Non-Party States: A Comparative Study', The Law and Practice of International Courts and Tribunals, 5(1), 495-527. 0.

Roscini, M. (2010) 'The United Nations Security Council and the Enforcement of International Humanitarian Law', Israel Law Review, 43(2), 330-359. o.; https://doi.org/10.1017/ So021223700000790.

SADAT, L. N. (2003) 'Summer in Rome, Spring in The Hague, Winter in Washington? U.S. Policy Towards the International Criminal Court', Wisconsin International Law Journal, 21(3), 557-597. 0.

SADAT, L. N. (2006) 'The International Criminal Court and Universal International Jurisdiction: A Return to First Principles' in Biersteker, T., Spiro, P., Sriram, C. L., Raffo, V. (eds.) Law and International Relations: Bridging Theory and Practice. London-New York: Routledge.

SADAT, L. N. (2003) 'The New International Criminal Court: An Uneasy Revolution' in Sadat, L. N., Carden, R. S. (eds.) International Crimes. London-New York: Routledge.

SAXUM, E. (2009-2010) 'The ICC versus Sudan: How Does the Darfur Case Impact the Principle of Complementarity?', Eyes on the ICC, 6(1), 1-12. o.

Schabas, W. A. (2017) An Introduction to the International Criminal Court. Cambridge: Cambridge University Press.

Schabas, W. A. (2011) Obama, Medvedev and Hu Jintao May be Prosecuted by International Criminal Court, Pre-Trial Chamber Concludes [Online]. Elérhető: http://humanrightsdoctorate. 
blogspot.com/2011/12/obama-medvedev-and-hu-jintao-may-be.html [Letöltve: 2021. 04 . 21.].

SchabAs, W. A. (2010) The International Criminal Court: A Commentary on the Rome Statute. Oxford: Oxford University Press.

Schabas, W. A. (2009) The International Criminal Court and Truth Commissions [Online]. Elérhetô: https://scholarlycommons.law.northwestern.edu/cgi/viewcontent.cgi?referer=\& httpsredir $=1 \&$ article $=1082 \&$ context=njihr [Letöltve: 2021.04 . 21.] .

SchabAs, W. A. (2008) 'The Special Tribunal for Lebanon: Is a "Tribunal of an International Character" Equivalent to an "International Criminal Court"?', Leiden Journal of International Law, 21(2), 513-528. o.; https://doi.org/10.1017/S0922156508005074.

SchabAs, W. A. (2004) 'United States Hostility to the International Criminal Court: It's All About the Security Council', European Journal of International Law, 15(4), 701-720. o.; https:// doi.org/10.1093/ejil/15.4.701

Scheffer, D. (2011) All the Missing Souls: A Personal History of the War Crimes Tribunals. Princeton: Princeton University Press.

SCheffer, D. (1999) 'The United States and the International Criminal Court', American Journal of International Law, 93(1), 12-22. o.; https://doi.org/10.2307/2997953.

Sснотт, J. (2007) 'Chapter VII as Exception: Security Council Action and the Regulative Ideal of Emergency', Northwestern Journal of International Human Rights, 6(1), 24-80. o.

SCHwelb, E. (1967) 'Withdrawal from the United Nations the Indonesian Intermezzo', American Journal of International Law, 61(3), 661-672. o.; https://doi.org/10.2307/2197461.

ScotT, D. A. (2002) 'Presidential Power to 'Un-Sign' Treaties', University ofChicago Law Review, 69(3), 1447-1477. 0.

SEILS, P. (2015) 'Putting Complementarity in its Place' in Stahn, C. (ed.) The Law and Practice of the International Criminal Court. Oxford: Oxford University Press.

SHAw, M. N. (2003) International Law. Cambridge: Cambridge University Press.

Sievers, L., Davis, S. (2014) The Procedure of the UN Security Council. Oxford: Oxford University Press.

Simma, B., Khan, D. E., Nolte, G., Paulus, A., Wessendorf, N. (2012) The Charter of the United Nations: A Commentary. Oxford: Oxford University Press.

Sluiter, G. (2008) 'Obtaining Cooperation from Sudan - Where is the Law?', Journal of International Criminal Justice, 6(5), 871-884. o.; https://doi.org/10.1093/jicj/mqno67.

Stahn, C. (2015) 'Admissibility Challenges before the ICC. From Quasi-Primacy to Qualified Deference?' in Stahn, C. (ed.) The Law and Practice of the International Criminal Court. Oxford: Oxford University Press.

Stahn, C. (2003) 'The Ambiguities of Security Council Resolution 1422 (2002)', European Journal of International Law, 14(1), 85-104. o.; https://doi.org/10.1093/ejil/14.1.85. 
Stahn, C. (2010) 'The 'End', the Beginning of the 'End' or the 'End of the Beginning'? Introducing Debates and Voices on the Definition of Aggression', Leiden Journal of International Law, 23(4), 875-882. o.; https://doi.org/10.1017/S0922156510000427.

SulYok, G. (2009) Az Egyesült Nemzetek Szervezetének Biztonsági Tanácsa: összetétel, szavazás, reform. Budapest: CompLex Kiadó Kft.

SulYok, G. (2003) A humanitárius intervenció elmélete és gyakorlata, PhD-értekezés. Miskolci Egyetem Állam- és Jogtudományi Kar.

Szalai A. (2018) 'Nemzetközi szerződések' in Jakab, A., Fekete, B. (szerk.) Internetes Jogtudományi Enciklopédia (Nemzetközi jog rovat, rovatszerkesztő: Sulyok, G.) [Online]. Elérhető: https://ijoten.hu/szocikk/nemzetkozi-szerzodesek [Letöltve: 2021. 04. 21.].

Tedeschini, M. (2015) 'Complementarity in Practice: The ICC's Inconsistent Approach in the Gaddafi and Al-Senussi Admissibility Decisions', Amsterdam Law Forum, 7(1), 76-97. o.; http://doi.org/10.37974/ALF.276.

TLADI, D. (2009) 'The African Union and the International Criminal Court: The Battle for the Soul of International Law', South African Yearbook of International Law, (34)1, 57-69. o.

TLADI, D. (2015) 'The Duty on South Africa to Arrest and Surrender President Al-Bashir under South African and International Law', Journal of International Criminal Justice, 13(5), 10271047. o.; https://doi.org/10.1093/jicj/mqv057.

Trahan, J. (2019) 'Revisiting the Role of the Security Council concerning the International Criminal Court's Crime of Aggression', Journal of International Criminal Justice, 17(3), 471483. o.; https://doi-org.eres.qnl.qa/10.1093/jicj/mqzo22.

Trahan, J. (2013) 'The Relationship between the International Criminal Court and the UN Security Council: Parameters and Best Practices', Criminal Law Forum, 24(1), 414-473. o.; https://doi.org/10.1007/s10609-013-9213-9.

Triffterer, O. (2008) 'Article 27 - Irrelevance of Official Capacity' in Triffterer, O. (ed.) Commentary on the Rome Statute of the International Criminal Court-Observers' Notes, Article by Article, C.H. München-Oxford-Baden-Baden: Beck-Hart-Nomos.

Udombana, N. (2005) 'Pay Back Time in Sudan? Darfur in the International Criminal Court', Tulsa Journal of Comparative and International Law, 13(1), 1-57. 0.

VAN ScHAACK, B. (2011) 'Negotiating at the Interface of Power \& Law: The Crime of Aggression', Columbia Journal of Transnational Law, 49(3), 1-66. o.

VALKI, L. (2014) 'Háború, erőszak, agresszió' in Kende, T., Nagy, B., Sonnevend, P., Valki, L. (eds.) Nemzetközi jog. Budapest: CompLex Kiadó.

VARGA R. (2006) 'A Római Statútum jelentősége a nemzetközi jogban és a nemzetközi büntetőjogban', Iustum Aequum Salutare, 2(1-2), 95-98. o. 
VARGA R. (2012) 'A Római Statútum végrehajtása nemzeti szinten, különös tekintettel a magyar büntetőjog rendszerére', Kül-Világ. A nemzetközi kapcsolatok folyóirata, 9(4), 76-86. o.

VARgA, R. (2014) Challenges of Domestic Prosecution of War Crimes with Special Attention to Criminal Justice Guarantees. Budapest: Pázmány Press.

Verduzco, D. R. (2015) 'The Relationship between the ICC and the United Nations Security Council' in Stahn, C. (ed.) The Law and Practice of the International Criminal Court. Oxford: Oxford University Press.

Villiger, M. E. (2009) Commentary on the Vienna Convention on the Law of Treaties. The Hague: Martinus Nijhoff.

WARBRICK, C. (1996) 'The International Criminal Tribunal for Yugoslavia: The Decision of the Appeals Chamber on the Interlocutory Appeal on Jurisdiction in the Tadic case', International and Comparative Law Quarterly, 45(3), 691-701. o.; https://doi.org/10.1017/ So020589300059431.

Wetzel, J. E., Mitri, Y. (2008) 'The Special Tribunal for Lebanon: A Court Off the Shelf for a Divided Country', The Law and Practice of International Courts and Tribunals, 7(1), 81-114. o.; https://doi.org/10.1163/157180308X311110.

ZimmermanN, A. (1998) 'The Creation of a Permanent International Criminal Court', Max Planck Yearbook on United Nations Law, 2(1), 169-237. o.

ZHU, D. (2014) 'China, the International Criminal Court and International Adjudication', Netherlands International Law Review, 61(1), 43-67. o. 



\section{Bírói döntések jegyzéke}

\section{ICC:}

Decision on the Prosecutor's Application for a Warrant of Arrest, The Prosecutor v. Thomas Lubanga Dyilo, ICC-01/04-01/06-8, 10 February 2006.

Decision concerning Pre-Trial Chamber I's Decision of 10 February 2006 and the Incorporation of Documents into the Record of the Case against Mr Thomas Lubanga Dyilo, The Prosecutor v Thomas Lubanga Dyilo, ICC-01/04-01/06-8-Corr, ICC Pre-Trial Chamber I, 24 February 2006.

Decision on the Prosecution Application under Article 58(7) of the Statute, The Prosecutor v. Ahmad Harun and Ali Kushayb, ICC-02/05-01/07-l-Corr, ICC Pre-Trial Chamber I, 27 April 2007.

Warrant of Arrest for Omar Hassan Ahmad Al Bashir, The Prosecutor v. Omar Hassan Ahmad al-Bashir, ICC-02/05-01/09, Pre-Trial Chamber I, 4 March 2009.

Judgment on the Appeal of Mr. Germain Katanga against the Oral Decision of Trial Chamber II of 12 June 2009 on the Admissibility of the Case, The Prosecutor v. Germain Katanga and Mathieu Ngudjolo Chui, ICC-01/04-01/07-1497 OA 8, ICC Appeal Chamber, 25 September 2009.

Second Warrant of Arrest for Omar Hassan Ahmad Al Bashir, The Prosecutor v. Omar Hassan Ahmad Al Bashir, ICC-02/05-01/09, Pre-Trial Chamber I, 12 July 2010.

Decision informing the United Nations Security Council and the Assembly of the States Parties to the Rome Statute about Omar Al Bashir's recent visit to the Republic of Chad, The Prosecutor v. Omar Hassan Ahmad Al Bashir, ICC-02/05-01/09-109, ICC Pre-Trial Chamber I, 27 August 2010.

Judgment on the appeal of Mr Jean-Pierre Bemba Gombo against the decision of Trial Chamber III of 24 June 2010 entitled "Decision on the Admissibility and Abuse of Process Challenges', The Prosecutor v. Jean-Pierre Bemba Gombo, ICC-01/05-01/08-962, ICC Appeals Chamber, 23 October 2010.

Decision requesting observations from the Republic of Kenya, The Prosecutor v. Omar Hassan Ahmad Al Bashir, ICC Pre-Trial Chamber I, ICC-02/05-01/09, 25 October 2010.

Decision informing the United Nations Security Council and the Assembly of the States Parties to the Rome Statute about Omar Al Bashir's recent visit to Djibouti, The Prosecutor v. Omar Hassan Ahmad Al Bashir, ICC-02/05-01/09-129, ICC Pre-Trial Chamber I, 13 May 2011. 
Judgment on the appeal of the Republic of Kenya against the decision of Pre-Trial Chamber II of 30 May 2011 entitled "Decision on the Application by the Government of Kenya Challenging the Admissibility of the Case Pursuant to Article 19(2)(b) of the Statute", Prosecutor v. Francis Kirimi Muthaura, Uhuru Muigai Kenyatta and Mohammed Hussein Ali, ICC-01/09-02/11-274, ICC Appeals Chamber, 30 August 2011.

Judgment on the appeal of the Republic of Kenya against the decision of Pre-Trial Chamber II pf 30 May 2011 entitled 'Decision on the Application by the Government of Kenya Challenging the Admissibility of the Case Pursuant to Article 19(2)(b) of the Statute, The Prosecutor v. William Samoei Ruto, Henry Kiprono Kosgey and Joshua Arap Sang, (Case No. ICC-01/09-02/11-274), ICC Appeals Chamber, 30 August 2011.

Decision on the Prosecutor's Application Pursuant to Article 58 for a warrant of arrest against Laurent Koudou Gbagbo, The Prosecutor v. Laurent Gbagbo, ICC-02/11-01/11-9-Red, ICC Pre-Trial Chamber III, 30 November 2011.

Decision Pursuant to Article 87(7) of the Rome Statute on the Failure by the Republic of Malawi to Comply with the Cooperation Requests Issued by the Court with Respect to the Arrest and Surrender of Omar Hassan Ahmad Al Bashir, The Prosecutor v. Omar Hassan Ahmad Al Bashir, ICC Pre-Trial Chamber I, ICC-02/05-01/09-140-tENG, 12 December 2011. Decision pursuant to article 87(7) of the Rome Statute on the refusal of the Republic of Chad to comply with the cooperation requests issued by the Court with respect to the arrest and surrender of Omar Hassan Ahmad Al Bashir, The Prosecutor v. Omar Hassan Ahmad Al Bashir, ICC-02/05-01/09-140-tENG, ICC Pre-Trial Chamber I, 13 December 2011.

Decision on the Confirmation of Charges Pursuant to Article 61(7)(a) and (b) of the Rome Statute, The Prosecutor v. Uhuru Muigai Kenyatta, ICC Pre-Trial Chamber II, ICC-01/0902/11-382-Red, 29 January 2012.

Application on behalf of the Government of Libya pursuant to Article 19 of the ICC Statute, The Prosecutor v. Saif Al-Islam Gaddafi and Abdullah Al-Senussi, ICC-01/11-01/11-130RedICC Pre-Trial Chamber I, 1 May 2012.

Prosecution's Response to "Libyan Government's further submissions on issues related to the admissibility of the case against Saif Al-Islam Gaddafi", The Prosecutor v. Saif Al-Islam Gaddafi and Abdullah Al-Senussi, ICC-01/11-01/11-276-Red2, ICC Pre-Trial Chamber I, 12 February 2013.

Decision on the Non-compliance of the Republic of Chad with the Cooperation Requests Issued by the Court Regarding the Arrest and Surrender of Omar Hassan Ahmad Al Bashir, The Prosecutor v. Omar Hassan Ahmad Al Bashir, ICC-02/05-01/09-140-151, ICC Pre-Trial Chamber II, 26 March 2013.

Decision on the admissibility of the case against Saif Al-Islam Gaddafi, The Prosecutor v. Saif Al-Islam Gaddafi, ICC-01/11-01/11-344-Red, ICC Pre-Trial Chamber I, 31 May 2013. 
Decision on the Cooperation of the Federal Republic of Nigeria Regarding Omar Al Bashir's Arrest and Surrender to the Court, The Prosecutor v. Omar Hassan Ahmad Al Bashir, ICC-02/05-01/09-159, ICC Pre-Trial Chamber II, 5 September 2013.

Decision on the Admissibility of the Case of Abdullah Al-Senussi, The Prosecutor v. Saif AlIslam Gaddafi and Abdullah Al-Senussi, ICC-01/11-01/11-466-Red, ICC Pre-Trial Chamber I, 11 October 2013.

Decision Regarding Omar Al-Bashir's Potential Travel to the State of Kuwait, The Prosecutor v. Omar Hassan Ahmad al-Bashir, ICC-02/05-01/09-192, PTC II, ICC, 24 March 2014.

Decision on the Cooperation of the Democratic Republic of the Congo Regarding Omar Al Bashir's Arrest and Surrender to the Court, The Prosecutor v. Omar Hassan Ahmad Al Bashir, ICC-02/05-01/09-195, ICC Pre-Trial Chamber II, 9 April 2014.

Judgment on the appeal of Libya against the decision of the Pre-Trial Chamber I of 31 May 2012 entitled "Decision on the admissibility of the case against Saif Al-Islam Gaddafi", The Prosecutor v. Saif Al-Islam Gaddafi, ICC-01/11-01/11-547-Red, ICC Appeals Chamber, 21 May 2014.

Judgment on the appeal of Mr Abdullah Al-Senussi against the decision of the Pre-Trial Chamber I of 11 October 2013 entitled "Decision on the admissibility of the case against Abdullah al-Senussi", The Prosecutor v. Saif Al-Islam Gaddafi, ICC-01/11-01/11-565, ICC Appeals Chamber, 24 July 2014.

Decision on Côte d'Ivoire's challenge to the admissibility of the case against Simone Gbagbo, The Prosecutor v. Simone Gbagbo, ICC-02/11-01/12, ICC Pre-Trial Chamber I, 11 December 2014.

Judgment on the appeal of Côte d'Ivoire against the decision of Pre-Trial Chamber I of 11 December 2014 entitled "Decision on Côte d'Ivoire's challenge to the admissibility of the case against Simone Gbagbo", The Prosecutor v. Simone Gbagbo, ICC-02/11-01/12 OA, ICC Appeals Chamber, 27 May 2015.

Decision on the Prosecutor's Request for Authorization of an Investigation. Separate Opinion of Judge Péter Kovács, Situation in Georgia, ICC Pre-Trial Chamber, Doc. ICC-01/1512-Anxi, 27 January 2016.

Decision on the non-compliance by the Republic of Djibouti with the request to arrest and surrender Omar Al Bashir to the Court and referring the matter to the United Nations Security Council and the Assembly of the State Parties to the Rome Statute, The Prosecutor v. Omar Hassan Ahmad Al Bashir, ICC-02/05-01/09-266, ICC Pre-Trial Chamber II, 11 July 2016.

Decision on the non-compliance by the Republic of Uganda with the request to arrest and surrender Omar Al Bashir to the Court and referring the matter to the United Nations Security Council and the Assembly of State Parties to the Rome Statute, The Prosecutor 
v. Omar Hassan Ahmad Al Bashir, ICC-02/05-01/09-267, ICC Pre-Trial Chamber II, 11 July 2016.

Decision under article 87(7) of the Rome Statute on the non-compliance by South Africa with the request by the Court for the arrest and surrender of Omar Al-Bashir, The Prosecutor v. Omar Hassan Ahmad Al Bashir, ICC-02/05-01/09-302, ICC Pre-Trial Chamber II, 6 July 2017.

Decision under article 87(7) of the Rome Statute on the non-compliance by Jordan with the request by the Court for the arrest and surrender or Omar Al-Bashir, The Prosecutor v. Omar Hassan Ahmad al-Bashir, ICC-02/05-01/09, Pre-Trial Chamber II, 11 December 2017.

The Hashemite Kingdom of Jordan's appeal against the "Decision under article 87(7) of the Rome Statute on the non-compliance by Jordan with the request by the Court for the arrest and surrender [of] Omar Al-Bashir", The Prosecutor v. Omar Hassan Ahmad AlBashir, ICC-02/05-01/09, ICC Appeals Chamber, 12 March 2018.

Admissibility Challenge by Dr. Saif Al-Islam Gaddafi pursuant to Articles 17(1)(c), 19 and 20(3) of the Rome Statute, The Prosecutor v. Saif Al-Islam Gaddafi, ICC-01/11-01/11, ICC PreTrial Chamber I, 5 June 2018.

Decision on the Prosecution's Request for a Ruling on Jurisdiction under Article 19(3) of the Statute, Preliminary examination of the Bangladesh/Myanmar Situation, Situation in Bangladesh/Myanmar, ICC-RoC46(3)-01/18, PTC I, ICC, 6 September 2018.

Public redacted version of "Prosecution response to 'Admissibility Challenge by Dr. Saif AlIslam Gaddafi pursuant to Articles $17(1)(c), 19$ and 20(3) of the Rome Statute" filed on 28 September 2018 (ICC-01/11-01/11-653-Conf), The Prosecutor v. Saif Al-Islam Gaddafi, ICC01/11-01/11, ICC Pre-Trial Chamber I, 11 October 2018.

Decision on the 'Admissibility Challenge by Dr. Saif Al-Islam Gadafi pursuant to Articles 17(1) (c), 19 and 20(3) of the Rome Statute', The Prosecutor v. Saif Al-Islam Gaddafi and Abdullah Al-Senussi, ICC-01/11-01/11-62, ICC Pre-Trial Chamber I, 5 April 2019.

Order setting the procedure and the schedule for the submission of observation, Situation on the State of Afghanistan, Situation in Afghanistan, ICC Pre-Trial Chamber I, ICC01/18-14, 12 April 2019.

Decision Pursuant to Article 15 of the Rome Statute on the Authorization of an Investigation into the Situation in the Islamic Republic of Afghanistan, Situation in Afghanistan, ICC Pre-Trial Chamber I, ICC-02/17, ICC Pre-Trial Chamber II, 12 April 2019.

Judgment in the Jordan Referral re Al-Bashir Appeal, The Prosecutor v. Omar Hassan Ahmad al-Bashir, ICC Appeals Chamber, ICC-02/05-01/09-397, 6 May 2019.

Defence Appeal Brief in support of its appeal against Pre-Trial Chamber I's "Decision on the 'Admissibility Challenge by Dr. Saif Al-Islam Gadafi pursuant to Articles 17(1)(c), 19 and 
20(3) of the Rome Statute", The Prosecutor v. Saif Al-Islam Gaddafi, ICC-o1/11-01/11, Appeals Chamber, 20 May 2019.

Judgment on the appeal of Mr Saif Al-Islam Gaddafi against the decision of Pre-Trial Chamber I entitled 'Decision on the "Admissibility Challenge by Dr. Saif Al-Islam Gadafi pursuant to Articles 17(1)(c), 19 and 20(3) of the Rome Statute"' of 5 April 2019, The Prosecutor v. Saif Al-Islam Gaddafi ICC-01/11-01/11, Appeals Chamber, 9 March 2020.

\section{ICJ:}

Reparation of Injuries Suffered in the Service of the United Nations, Advisory Opinion of 11 April 1949, I.C.J. Reports 1949.

Certain Expenses of the United Nations, Advisory Opinion of 20 July 1962, I.C.J. Reports 1962. North Sea Continental Shelf Cases (Federal Republic of Germany v. Denmark and the Netherlands), Judgment of 20 February 1969, I.C.J. Reports 1969.

Legal Consequences for States of the Continued Presence of South Africa in Namibia (South West Africa) notwithstanding Security Council Resolution 276 (1970), Advisory Opinion of 21 June 1971, I.C.J. Reports 1971.

Case Concerning Military and Paramilitary Activities in and against Nicaragua (Nicaragua v. the US), Judgment of 27 June 1986, I.C.J. Reports 1986.

Questions of Interpretation and Application of the 1971 Montreal Convention Arising from the Aerial Incident at Lockerbie (Libya v. U.S.), 1992 I.C.J. Reports 114.

Case Concerning the Arrest Warrant of 11 April 2000 (Democratic Republic of the Congo v. Belgium), Judgment of 14 February 2002, I.C.J. Reports 2002.

Legal Consequences of the Construction of a Wall in Palestinian Territory, Advisory Opinion of 9 July 2004, I.C.J. Reports 2004.

Case Concerning Armed Activities on the Territory of the Congo (Democratic Republic of Congo v. Uganda), Judgment of 19 December 2005, I.C.J. Reports 2005.

Case Concerning Certain Questions of Mutual Assistance in Criminal Matters (Djibouti v. France), Judgment of 4 June 2008 , I.C.J. Reports 2008.

Jurisdictional Immunities of the State (Germany v. Italy: Greece Intervening), Judgment of 3 February 2012, I.C.J. Reports 2012. 


\section{ICTY:}

Decision on Defence Motion on Jurisdiction, The Prosecutor v. Duško Tadić (IT-94-1-T), Trial Chamber, 10 August 1995.

Decision on Defence Motion for Interlocutory Appeal on Jurisdiction, The Prosecutor v. Duško Tadić (IT-94-1-AR72), Appeals Chamber, 2 October 1995.

Prosecutor v. Anto Furundžija, IT-95-17/1-T, Judgment, International Tribunal for the Prosecution of Persons Responsible for Serious Violations of International Humanitarian Law Committed in the Territory of the Former Yugoslavia since 1991, The Hague, 10 December 1998.

Prosecutor v. Slobodan Milošević, IT-02-54, Decision on the Preliminary Motions, 8 November 2001.

Prosecutor v. Krstić, IT-98-33, Decision on Application of Subpoenas, I July 2003.

Prosecutor v. Tihomor Blaskić, IT-95-14-A, Judgment, International Tribunal for the Prosecution of Persons Responsible for Serious Violations of International Humanitarian Law Committed in the Territory of the Former Yugoslavia since 1991, The Hague, 29 July 2004. Prosecutor v. Radovan Karadžić, IT-95-5/18-T, Judgment, International Tribunal for the Prosecution of Persons Responsible for Serious Violations of International Humanitarian Law Committed in the Territory of the Former Yugoslavia since 1991, The Hague, 24 March 2016.

\section{PCIJ:}

The Status of Eastern Carelia, Advisory Opinion, 7 February 1923, P.C.I.J. Series, No. 5.

Certain German Interests in Polish Upper Silesia Case (Germany v. Poland), Judgment No. 7. 25 May 1926. P.C.I.J. Series A, No. 7.

Free Zones Case of Upper Savoy and the District of Gex Case (France v. Switzerland), Judgment No. 46.7 June 1932. P.C.I.J. Series A/B, No. 46. 


\section{STL:}

Decision on the Defence Appeals against the Trial Chamber's Decision on the Defence Challenges to the Jurisdiction and Legality of the Tribunal, The Prosecutor v. Ayyash et al. (STL-11-01/AC/AR90.1), Appeals Chamber, 24 October 2012.

Procedural Decision on Defence Motions Challenging, The Prosecutor v. Salim Jamil Ayyash et al. (STL-11-01/PT/TC), Trial Chamber, 18 May 2012.

Separate and Partially Dissenting Opinion of Judge Baragwanath, Decision on the Defence Appeals against the Trial Chamber's 'Decision on the Defence Challenges to the Jurisdiction and Legality of the Tribunal', The Prosecutor v. Ayyash et al. (STL-11-01/AC/AR90.1), Appeals Chamber, 24 October 2012.

Separate and Partially Dissenting Opinion of Judge Riachy, Decision on the Defence Appeals against the Trial Chamber's 'Decision on the Defence Challenges to the Jurisdiction and Legality of the Tribunal', The Prosecutor v. Ayyash et al. (STL-11-01/AC/AR90.1), Appeals Chamber, 24 October 2012.

\section{Egyéb bírói fórumok:}

Attorney General v. Adolf Eichmann, Criminal Case No. 40/46, Judgment, District Court of Jerusalem, Israel, 11 December 1961.

Regina v. Bartle and the Commissioner of Police for the Metropolis and others ex parte Pinochet / Regina v. Evans and another and the Commissioner of Police for the Metropolis and others ex parte Pinochet, Opinions of the Lords of Appeal for Judgement in the Cause, House of Lords, 25 November 1998.

The Prosecutor v. Charles Ghankay Taylor, Case No. SCSL-03-01-A, Judgment, Special Court for Sierra Leone, The Hague, 26 September 2013. 



\section{A szerző témához kapcsolódó publikációi}

BÉRES, N. (2019) 'The Role of the Security Council in International Criminal Justice: A Comparative Analysis of the ICTY and the STL', Publicationes Universitatis Miskolcinensis, Sectio Juridica et Politica 37(2), 123-143. o.

BÉRES, N. (2019) 'A Római Statútum alkalmazhatóságának kérdései és kihívásai harmadik államok esetén', Fontes Iuris. Az Igazságügyi Minisztérium Szakmai folyóirata, 5(3), 24-32. o.

BÉRES, N. (2019) ‘Törésvonalak a nemzetközi elszámoltathatóság terén. A Nemzetközi Büntetőbíróság és az Afrikai Unió viszonya', Állam-és Jogtudomány, 50(1), 5-18. o.

BÉRES, N. (2018) 'A komplementaritás elvének érvényesülése, különös tekintettel a líbiai helyzetre' in P. Szabó, B., Zaccaria, M. L., Árva, Zs. (szerk.) Profectus in litteris IX.: Előadások a 14. debreceniállam-ésjogtudományi doktoranduszkonferencián. Debrecen: Lícium Art Kiadó.

BÉREs, N. (2017) 'A Nemzetközi Büntetôbíróság mint félkarú óriás? Az együttmúködési kötelezettség és az államfői immunitás összeütközése esetén alkalmazható megközelítési módok a hatékonyság elvének tükrében' in Bragyova, A. (szerk.) Studia Iurisprudentiae Doctorandorum Miskolciensium - Miskolci Doktoranduszok Jogtudományi Tanulmányai. Miskolc: Gazdász-Elasztik Kft. Kiadó.

BÉRES, N. (2017) 'A Nemzetközi Büntetőbíróság államokkal való együttmúködésének problémája, különös tekintettel az államfői immunitás kérdésére' in Szabó, M. (szerk.) Doktoranduszok Fóruma: Állam-és Jogtudományi Kar szekciókiadványa. Miskolc: Miskolci Egyetem. BÉRES, N. (2016) 'A Dárfúrtól Hágáig vezető út, avagy az ENSZ Biztonsági Tanács 1593. (2005) határozatának jelentősége a Nemzetközi Büntetőbíróság történetében' in Koncz, I., Szova, I. (szerk.) PEME 12. PhD-konferencia. Budapest: Professzorok az Európai Magyarországért Egyesület.

BÉRES, N. (2016) 'A Nemzetközi Büntetőbíróság és az ENSZ Biztonsági Tanácsának kapcsolata által felvetett legfontosabb gyakorlati problémák' in Kecskés, G. (szerk.) Doktori Mühelytanulmányok 2016. Győr: Széchenyi István Egyetem Állam- és Jogtudományi Doktori Iskola. BÉRES, N. (2016) 'A líbiai helyzet a Nemzetközi Büntetőbíróság előtt' in Keresztes, G. (szerk.) Tavaszi Szél 2016 - Spring Wind 2016. Tanulmánykötet. I. kötet: Agrártudomány, állam-és jogtudomány, föld-és fizikatudomány, had-és rendészettudomány'. Budapest: Doktoranduszok Országos Szövetsége.

BÉres, N. (2016) Réka Varga: Challenges of Domestic Prosecution of War Crimes with Special Attention to Criminal Justice Guarantees (recenzió), Állam-és Jogtudomány, 57(2), 102-107. o. 
BÉRES, N. (2016) 'The Principle of Complementarity in Practice Based on the Case-Law of the International Criminal Court' in Kékesi, T. (ed.) The Publications of the MultiScience-XXX. microCAD International Multidisciplinary Scientific Conference. Miskolc: Miskolci Egyetem.

BÉRES, N. (2015) Gondolatok a Nemzetközi Büntetőbíróság joghatóságának vitás kérdéseiről, Publicationes Universitatis Miskolcinensis, Sectio Juridica et Politica, 33(1), 203-212. o.

BÉRES, N. (2015) 'Az ICC joggyakorlatának kezdeti kihívásai: a dárfúri helyzet a nemzetközi büntetőbírói fórum előtt' in Bragyova, A. (szerk.) Studia Iurisprudentiae Doctorandorum Miskolciensium - Miskolci Doktoranduszok Jogtudományi Tanulmányai. Miskolc: GazdászElasztik Kft. Kiadó.

BÉRES, N. (2015) 'A Nemzetközi Büntetőbíróság joghatósága, különös tekintettel az eljárást indító mechanizmusokra' in P. Szabó, B., Szemesi, S. (szerk.) Profectus in litteris VII.: Előadások a 12. debreceni állam-és jogtudományi doktoranduszkonferencián. Debrecen: Lícium Art Kiadó.

BÉRES, N. (2015) 'Reflections on Some Disputed Issues Related to the Jurisdiction of the International Criminal Court' in Universitatea "Nicolae Titulescu” "CONSTANT 2015" - CONFERINŢA STUDENŢEASCĂ ANUALĂ: Universitatea „Nicolae Titulescu” Bucureşti, 24-25 aprilie 2015 (e-Book). Bukarest: Nicolae Titulescu Egyetem.

BÉRES, N. (2015) 'A komplementaritás elve a Nemzetközi Büntetőbíróság joggyakorlata tükrében' in Róth, E. (szerk.) Via scientiae iuris - International Conference of PhD Students in Law. Miskolc: Gazdász-Elasztik Kft.

BÉres, N. (2015) 'Crucial Aspects of the Relationship Between the ICC and the Security Council’ in Szabó, M. (szerk.) Doktoranduszok Fóruma:Állam-és Jogtudományi Kar Szekciókiadványa. Miskolc: Miskolci Egyetem.

BÉRES, N. (2015) 'Thoughts about Crimes Against Humanity’ in Szabó, M. (szerk.) Doktoranduszok Fóruma: Állam-és Jogtudományi Kar szekciókiadványa. Miskolc: Miskolci Egyetem. 


\section{A sorozatban eddig megjelent múvek:}

1. Veress Emőd: A szindikátusi szerződés

2. Domaniczky Endre: Határterületeken

3. Szilágyi János Ede, Hrecska-Kovács Renáta (szerk.):

A sztrájkjog összehasonlitó jogi elemzése egyes európai államokban

4. Nagy Zoltán, Horváth Attila (szerk.):

A különleges jogrend és nemzeti szabályozási modelljei 
